LÉZIO SOARES BUENO JÚNIOR

Plasticidade sináptica no córtex pré-frontal induzida por estimulação do tálamo mediodorsal de ratos in vivo: efeitos da modulação colinérgica muscarínica e nicotínica

Tese apresentada à Faculdade de Medicina de
Ribeirão Preto da Universidade de São Paulo, como
parte das exigências para a obtenção do título de
Doutor em Ciências. Área de concentração:
Neurociências.

Orientador: Prof. Dr. João Pereira Leite

RIBEIRÃO PRETO - SP 
Autorizo a reprodução e divulgação total ou parcial deste trabalho, por qualquer meio convencional ou eletrônico, para fins de estudo e pesquisa, desde que citada a fonte.

Bueno Júnior, Lézio Soares

Plasticidade sináptica no córtex pré-frontal induzida por estimulação do tálamo mediodorsal de ratos in vivo: efeitos da modulação colinérgica muscarínica e nicotínica / Lézio Soares Bueno Júnior. - - Ribeirão Preto, 2012.

137 p. : il. ; $30 \mathrm{~cm}$

Orientador: João Pereira Leite

Tese (doutorado) - Faculdade de Medicina de Ribeirão Preto da Universidade de São Paulo. Área de concentração: Neurociências.

1. Potencialização de longa duração. 2. Depressão de longa duração. 3. Córtex pré-frontal. 4. Tálamo mediodorsal. 5. Pilocarpina. 6. Nicotina. 7. Anestesia por uretana. 
Bueno-Júnior LS. Plasticidade sináptica no córtex pré-frontal induzida por estimulação do tálamo mediodorsal de ratos in vivo: efeitos da modulação colinérgica muscarínica e nicotínica. Tese apresentada à Faculdade de Medicina de Ribeirão Preto da Universidade de São Paulo, como parte das exigências para a obtenção do título de Doutor em Ciências. Área de concentração: Neurociências.

Aprovado em:

\section{Banca examinadora}

Prof. Dr. Instituição:

Julgamento:

Assinatura:

Prof. Dr.

Instituição:

Julgamento:

Assinatura:

Prof. Dr. Instituição:

Julgamento:

Assinatura:

Prof. Dr. Instituição:

Julgamento:

Assinatura:

Prof. Dr. Instituição:

Julgamento: Assinatura: 
Dediquei o mestrado à minha namorada. Agora, dedico o doutorado à minha esposa. Ainda bem que estou falando da mesma pessoa: Gabi. 


\section{Agradecimentos}

Sou privilegiado por ter dois orientadores: Profs. Drs. João Pereira Leite e Rodrigo Neves Romcy Pereira. Agradeço a ambos, pois de maneiras complementares me ensinaram a enxergar mais nitidamente o significado da carreira científica em longo prazo. Felizmente, o Brasil está sendo capaz de manter pesquisadores como estes, cujas contribuições acompanham a tendência internacional.

Estendo meu agradecimento à Faculdade de Medicina de Ribeirão Preto e sua pósgraduação, cuja história de contribuição à pesquisa brasileira eu reverencio e respeito. Incluo neste contexto o Prof. Dr. Norberto Garcia Cairasco, que com a energia que Ihe é característica está se esforçando para tornar nossa pesquisa mais acessível ao público.

Agradeço, também, a quatro pessoas importantes para nosso laboratório e departamento. Refiro-me à Renata Caldo Scandiuzzi, Silvana Lo Turco, Sílvia Festucci e Antônio Renato Meirelles e Silva. Devo à Renata a paciência e cuidado que passei a ter com o criostato, lâminas, e preparação de soluções, atividades que antigamente me aborreciam. Quanto à Silvana, agradeço pela paciência com que recebe ligações e visitas, algumas delas em momentos de preocupação com prazos. Obrigado à Sílvia, por nos assessorar com a cansativa burocracia das compras necessárias ao laboratório. E quanto ao bem-humorado Renato, agradeço-o por seu desprendimento em não somente assessorar tecnicamente os pós-graduandos, mas também orientá-los nos caminhos tortuosos das reformas e reparos.

Registro, também, meu agradecimento a todos os colegas do laboratório, tanto aqueles que conheço há alguns anos (Ana Clara, Ana Cláudia, Grazi, Jana, Ludy, Márcia, Mariana, Priscila, Raquel, Zé Eduardo) quanto os que conheci mais recentemente (Danilo, Dani Wolf, Ingrid e Patrícia). Em especial, agradeço à Dani Wolf pela dedicação que vem demonstrando na colaboração centralizada em seu projeto e, também, à Ludy, por confiar em seus calouros como coautores.

Pela densa interface entre trabalho e amizade, agradeço aos ainda-verdes Caio, Cleiton, Matheus, Milton, Nando e Rafa (alguns dos quais com apelidos que não cabem aqui). Espero que carreguemos uns aos outros em nossas bagagens durante as futuras mudanças de ares. Neste contexto, incluo também Fernando Padovan e Zé Luiz, que apesar da convivência diminuída continuam por perto. Particularmente, peço desculpas aos Eletroecos pelas limitações de agenda causadas pela finalização desta tese.

Deixo meu obrigado difuso às minhas numerosas famílias materna e paterna, especialmente a todos os que apoiaram minhas escolhas acadêmicas sem preconceitos. Pelo mesmo motivo, agradeço à família (tão numerosa quanto) da Gabi. Destaco o agradecimento às irmãs Liginha e Giovanna, aos vizinhos Marina e Samuel, e aos sogros/amigos Bia e Odamar pelo apoio e compreensão. Em especial, agradeço à minha mãe, que foi a primeira a me abraçar quando soube que eu viria a ser biólogo.

Por fim, obrigado ao CNPq e FAPESP pelo financiamento do projeto, e à assessoria ad hoc da FAPESP pelo acompanhamento atento e motivador. 
Penso que há localizações cerebrais extremamente precisas, na tradição da frenologia de Gall, por exemplo as áreas visuais, as áreas auditivas, as áreas especializadas na visão das cores ou no reconhecimento dos rostos e, ao mesmo tempo - e aí abordamos a tese sobre a consciência - um sistema de conexões a longa distância que são suscetíveis de criar ligações, relações entre múltiplos territórios do cérebro. Portanto, há globalidade e unidade e, ao mesmo tempo, diversidade e especialização.

Jean-Pierre Changeux, em entrevista à Pesquisa FAPESP, 2011 


\section{Resumo}

Bueno-Júnior LS. Plasticidade sináptica no córtex pré-frontal induzida por estimulação do tálamo mediodorsal de ratos in vivo: efeitos da modulação colinérgica muscarínica e nicotínica [tese]. Ribeirão Preto: Universidade de São Paulo, Faculdade de Medicina de Ribeirão Preto, 2012. 137 p.

O núcleo talâmico mediodorsal (Tmd) e o córtex pré-frontal (CPF) comunicam-se mutuamente, formando um circuito envolvido em funções executivas e transtornos psiquiátricos. As funções executivas estão sujeitas aos níveis de alerta gerados pela atividade oscilatória talamocortical, que por sua vez é controlada pela transmissão colinérgica. Possivelmente, a plasticidade sináptica do circuito Tmd-CPF é sensível tanto aos padrões oscilatórios do próprio circuito quanto à modulação colinérgica. Porém, esta possibilidade ainda não foi testada, muito menos dissociando-se a participação dos receptores muscarínicos e nicotínicos. Assim, nosso objetivo foi examinar como a plasticidade Tmd-CPF é modulada sob estados oscilatórios globais mediados pelo sistema colinérgico, e se esta modulação varia com os tipos de receptores recrutados. Anestesiamos ratos com uretana e implantamos um eletrodo de estimulação no Tmd, um eletrodo de registro no CPF e uma cânula de microinjeção acima do ventrículo. Emitimos 90 pulsos elétricos no Tmd $(0,05 \mathrm{~Hz})$ para evocação de potenciais pós-sinápticos de campo (PPSCs) basais no CPF por $30 \mathrm{~min}$. Em seguida, aplicamos injeção intraventricular do agonista muscarínico pilocarpina (PILO), do agonista nicotínico nicotina (NIC), ou veículo-controle (VEIC). Os efeitos das substâncias sobre potenciais de campo locais (eletrencefalograma) foram monitorados através dos mesmos eletrodos. PILO e NIC induziram aumento das oscilações rápidas $(4-80 \mathrm{~Hz})$ e proporcional redução das oscilações lentas mantidas pela anestesia $(0,5-4 \mathrm{~Hz})$ e tais efeitos duraram 10-15 min, conforme padronização prévia das concentrações das drogas. Justamente durante este período, aplicamos estimulação em alta frequência (EAF) ou baixa frequência (EBF) para indução de, respectivamente, potencialização (PLD) ou depressão (DLD) de longa duração, que são modelos bem conhecidos de plasticidade sináptica. Em grupos-controle, a injeção de PILO, NIC ou VEIC foi desacompanhada de EAF/EBF. Por fim, retomamos a coleta de PPSCs a $0,05 \mathrm{~Hz}$ por 240 min. Os resultados mostraram que a EAF não afetou os PPSCs quando aplicada após VEIC. Porém, nos ratos PILO e NIC, os PPSCs tiveram amplitude aumentada a partir de 150 min após EAF, indicando que a pré-ativação colinérgica foi necessária à indução de uma PLD tardia. Inversamente, quando a EBF foi aplicada após VEIC, a amplitude dos PPSCs foi reduzida de modo estável por $240 \mathrm{~min}$. Isto não ocorreu quando a EBF foi aplicada após PILO e NIC, sugerindo que a modulação colinérgica suprimiu a DLD. Nos grupos-controle, PILO, NIC e VEIC sozinhos não afetaram os PPSCs em longo prazo, confirmando que os resultados de PLD e DLD são devidos a uma interação entre a pré-ativação colinérgica e mecanismos sinápticos desencadeados pela EAF/EBF. Portanto, as oscilações rápidas induzidas pela transmissão colinérgica favorecem a PLD no circuito Tmd-CPF, enquanto dificultam sua DLD. Além disto, os efeitos muscarínicos e nicotínicos sobre a plasticidade de longo prazo são iguais, apesar de os mecanismos celulares destes receptores serem diferentes. Nossos achados ajudam a esclarecer a regulação do sinal talâmico no CPF sob modulação colinérgica fisiológica (atenção e sono paradoxal) e disfuncional (esquizofrenias e doença de Alzheimer).

Palavras-chave: Potencialização de longa duração. Depressão de longa duração. Córtex préfrontal. Tálamo mediodorsal. Pilocarpina. Nicotina. Anestesia por uretana. 


\begin{abstract}
Bueno-Júnior LS. Prefrontal cortical synaptic plasticity induced by stimulation of the rat mediodorsal thalamus in vivo: effects of cholinergic muscarinic and nicotinic modulation [thesis]. Ribeirão Preto: University of São Paulo, Ribeirão Preto School of Medicine, 2012. $137 \mathrm{p}$.
\end{abstract}

The mediodorsal thalamic nucleus (MD) and the prefrontal cortex (PFC) communicate with each other, constituting a circuit involved in executive functions and psychiatric disorders. Executive functions are subject to arousal levels driven by the thalamocortical oscillatory activity, which in turn is controlled by the cholinergic neurotransmission. Possibly, the MDPFC synaptic plasticity is susceptible to both the oscillatory patterns within the MD-PFC circuit and the cholinergic modulation. However, this likelihood is still untested, as well as the specific roles of muscarinic and nicotinic receptors. Thus, our aim was to evaluate whether and how the MD-PFC plasticity is modulated under cholinergic system-dependent oscillatory states of the forebrain, and if such modulation varies with the subtypes of activated cholinergic receptors. For that, we anesthetized rats with urethane to implant a stimulating electrode into the MD, a recording electrode into the PFC, and a microinjection cannula above the ventricle. We applied 90 monophasic square pulses into the MD $(0.05 \mathrm{~Hz})$ for recording of basal field postsynaptic potentials (fPSPs) in the PFC for $30 \mathrm{~min}$. Then, we did an intraventricular injection of either the muscarinic agonist pilocarpine (PILO), the nicotinic agonist nicotine (NIC), or a control vehicle (Veh). The drug effects on local field potentials (electroencephalogram) were monitored through the same electrodes. PILO and NIC induced an increase in theta, beta and gamma oscillations $(4-80 \mathrm{~Hz})$ with proportional reduction of urethane-driven delta waves $(0.5-4 \mathrm{~Hz})$, and these effects survived approximately 10-15 min according to pilot-experiments on PILO and NIC concentrations. During this period, we applied either high-frequency (HFS) or low-frequency stimulation (LFS) for induction of respectively long-term potentiation (LTP) or depression (LTD), which are well-known synaptic plasticity models. In control groups, the injection of PILO, NIC or Veh was not followed by the HFS/LFS. Lastly, we resumed the evoking of fPSP at $0.05 \mathrm{~Hz}$ for an additional $240 \mathrm{~min}$. The results showed that the HFS did not affect the fPSPs when applied after the Veh. However, in PILO and NIC rats the fPSP had their amplitudes increased from 150 min after HFS, indicating that the cholinergic pre-activation was required for the induction of a late-phase LTP. On the other hand, when the LFS was applied after the Veh, the fPSP amplitudes were stably decreased for $240 \mathrm{~min}$, which did not occur when the LFS was applied after PILO and NIC, suggesting that the cholinergic modulation suppressed the LTD. In the control groups, PILO, NIC, and Veh by themselves did not change fPSPs in the long term, reinforcing that the LTP and LTD were due to an interaction between the cholinergic pre-activation and synaptic mechanisms triggered by the HFS/LFS. Therefore, the rapid oscillations induced by the cholinergic transmission favor LTP in the MD-PFC loop, while occlude its LTD. Moreover, the muscarinic and nicotinic effects on long-term plasticity were equal, although their quite distinct cell mechanisms. Our findings might help clarify the regulation of thalamic signals on the PFC both under physiological (attention and rapid-eyemovement sleep) and dysfunctional (schizophrenia symptoms and Alzheimer's) cholinergic drive.

Keywords: Long-term potentiation. Long-term depression. Prefrontal cortex. Mediodorsal thalamus. Pilocarpine. Nicotine. Urethane anesthesia. 


\section{Lista de figuras}

Figura 1 Mapa parcial de aferências talâmicas ao CPFm e córtex motor medial, identificadas por traçador axonal retrógrado (extraído de Hoover e Vertes, 2007). 30

Figura 2 Diagrama simplificado do circuito Tmd-CPFm, destacando suas conexões excitatórias mais densas.

Figura 3 Principais vias ascendentes do sistema colinérgico de roedores. 51

Figura 4 Perfurações feitas ao crânio dos ratos para acesso às regiões encefálicas de interesse. 60

Figura 5 Representação esquemática do equipamento de eletrofisiologia, eletrodos e cânula de microinjeção. 63

Figura 6 Fotografias do equipamento de eletrofisiologia, para visão geral. 65

Figura $7 \quad$ PPSC típico, sua medida de amplitude e curva E/S. 67

Figura 8 Trens de pulsos elétricos para indução de plasticidade sináptica. 70

Figura 9 A latência e duração dos efeitos da NIC intraventricular sobre a atividade oscilatória prosencefálica dependem da concentração da droga. 78

Figura 10 Validação histológica dos implantes e perfil de PPSCs evocados no CPFm ao longo do trajeto dorso-ventral do eletrodo de estimulação. 83

Figura 11 Bandas de frequências dos PCLs e suas potências relativas, comparando-se a atividade oscilatória cortical e talâmica antes, durante e depois da microinjeção de PILO, NIC ou VEIC. 84

Figura 12 A EAF induziu uma PLD de manifestação tardia somente quando aplicada durante os efeitos temporários de PILO e NIC. 86

Figura 13 A EBF induziu uma DLD estável somente quando aplicada durante o contexto de ondas lentas da anestesia.

Figura 14 A microinjeção de PILO e NIC, por si só, não induziu mudanças de longo prazo sobre os PPSCs. Particularmente, NIC induziu potencialização breve. 88

Figura 15 Os efeitos de PILO e NIC prévios à EAF foram correlacionados com a PLD que se manifestou mais de duas horas depois. 90 
Figura 16 pico negativo das respostas pré-frontais evocadas pelo Tmd é passível de facilitação por pulsos pareados, o que constitui evidência adicional da sua natureza pós-sináptica.

Figura 17 Modelo propondo a plasticidade em rede da via CA1-CPF e do circuito TmdCPF, bem como a regulação de tal plasticidade pelos estados oscilatórios do sono. 106 


\section{Lista de tabelas}

Tabela 1 Amplitude e latência do pico negativo dos PPSCs basais. 


\section{Lista de abreviaturas e siglas}

$\alpha 4 \beta 2$ e $\alpha 7 \quad$ Receptores nicotínicos mais prevalentes do encéfalo e mais sensíveis à nicotina

AMPA Sigla inglesa para ácido alfa-amino-3-hidroxi-5-metil-4-isoxazol propiônico, um tipo de receptor glutamatérgico

ANOVA Sigla inglesa para análise de variância

APV Sigla inglesa para ácido (2R)-amino-5-fosfonovalérico, um antagonista de receptores NMDA

ATV Área tegmental ventral

BNC Sigla inglesa para conector-baioneta Neill-Concelman

CA1 e CA3 Cornu ammonis 1 e 3 do hipocampo

$\mathrm{Ca}^{2+} \quad$ Íons cálcio

$\mathrm{CaCl}_{2} \quad$ Cloreto de cálcio

CAm Córtex agranular medial, parte do córtex motor

CB1 Receptor canabinóide 1

CCa Córtex cingulado anterior, área dorsal do córtex pré-frontal medial

CNQX 6-ciano-7-nitroquinoxalina-2,3-diona, um antagonista de receptores AMPA

CPF Córtex pré-frontal

CPFdl Córtex pré-frontal dorsolateral

CPFm Córtex pré-frontal medial

Ctrl Controle

DLD Depressão de longa duração, um modelo de plasticidade sináptica

E/S Entrada/saída, razão entre intensidade do pulso elétrico e resposta de campo

EAF Estimulação em alta frequência, indutora de potencialização sináptica

Estimulação em baixa frequência, indutora de depressão sináptica 
Valor de Fisher (ANOVA)

GABA Sigla inglesa para ácido gama-aminobutírico, neurotransmissor inibitório do sistema nervoso central adulto

Grupo-M $\quad$ Conjunto formado pelos receptores muscarínicos $M_{1}, M_{3}$ e $M_{5}$

Grupo- $M_{2} \quad$ Conjunto formado pelos receptores muscarínicos $M_{2}$ e $M_{4}$

IL Área infra-límbica do córtex pré-frontal medial

$\mathrm{K}^{+} \quad$ Íons potássio

$\mathrm{KCl} \quad$ Cloreto de potássio

$\mathrm{K}_{\text {ir }} \quad$ Sigla inglesa para canais retificadores por influxo de íons potássio

LDT Núcleo laterodorsal do tegmento mesencefálico

LiCl Cloreto de lítio

$M_{1}-M_{5} \quad$ Diversidade de receptores muscarínicos $\left(M_{1}, M_{2}, M_{3}, M_{4}\right.$ e $\left.M_{5}\right)$

$\mathrm{Mg}^{2+} \quad$ Íons magnésio

$\mathrm{MgCl}_{2} \quad$ Cloreto de magnésio

n Número de indivíduos da amostra

N1 e N2 Picos negativos de nossos potenciais pós-sinápticos de campo

$\mathrm{Na}^{+} \quad$ ĺons sódio

$\mathrm{NaCl} \quad$ Cloreto de sódio

NBM Nucleus basalis magnocellularis

NIC Nicotina, hidrogeno-tartarato de (-)-nicotina

NMDA N-metil-D-aspartato, um tipo de receptor glutamatérgico

P55 Pré-amplificador analógico com filtro de frequências, Grass Technologies, EUA

PCLs Potenciais de campo locais (eletrencefalograma profundo)

pH Potencial hidrogeniônico 
PILO Pilocarpina, cloridrato de pilocarpina

PLD Potencialização de longa duração, um modelo de plasticidade sináptica

PPSC Potencial pós-sináptico de campo

PPT Núcleo pedunculopontino do tegmento mesencefálico

PrL Área pré-límbica do córtex pré-frontal medial

PSIU6 Unidade fotoelétrica para isolamento de estímulos, Grass Technologies, EUA

S88 Estimulador, Grass Technologies, EUA

Tmd Núcleo talâmico mediodorsal

TRt Núcleo talâmico reticular

VEIC Substância-controle (líquido cerebrospinal artificial)

VL Ventrículo lateral

Zif-268 Um dos fatores de transcrição codificados por genes de expressão imediata 


\section{Sumário}

1. Revisão da literatura ___ 18

1.1. Circuitos talamocorticais e corticotalâmicos _ـ 19

1.1.1. Anatomia e ontogenia __ 19

1.1.2. Fisiologia _ 21

1.2. Córtex pré-frontal em sua conectividade com o tálamo _ـ 26

1.2.1. Estudos em roedores _ 28

1.2.2. Plasticidade sináptica ___ 34

1.2.3. Estudos em humanos

1.3. Sistema colinérgico encefálico

1.3.1. Acetilcolina e fármacos colinérgicos _ـ 41

1.3.2. Receptores muscarínicos __ 43

1.3.3. Receptores nicotínicos

1.3.4. Projeções ascendentes e fisiologia __ 47

1.3.5. O sistema colinérgico sob anestesia por uretana ___

2. Justificativa dos experimentos e seu objetivo geral ___ 55

2.1. Objetivos específicos

3. Material e método

3.1. Sujeitos 59

3.2. Cirurgia e eletrofisiologia

3.2.1. Estereotaxia e cânula _ 59

3.2.2. Eletrodo de registro e eletrencefalograma ___ 61

3.2.3. Eletrodo de estimulação, pulsos elétricos e PPSCs ___ 64

3.3. Drogas colinérgicas _ 65

3.4. Desenho experimental ___ 66

3.4.1. Polaridade de estimulação, curva de entrada/saída e atividade basal ___ 66

3.4.2. Injeção das drogas com registro da atividade oscilatória ___ 68 
3.4.3. Indução de plasticidade sináptica e seu monitoramento 69

3.4.4. Lesão eletrolítica, decapitação e histologia _ـ 70

3.4.5. Grupos experimentais _ 71

3.5. Análise dos dados

3.5.1. Atividade oscilatória

3.5.2. Plasticidade sináptica __ 73

3.5.3. Correlações lineares _ 74

4. Experimentos preparatórios e padronizações___ 76

4.1. Padronização das coordenadas estereotáxicas de estimulação ___ 76

4.2. Padronização da concentração das drogas conforme a duração de seus efeitos __ 77

5. Resultados dos experimentos principais ___ 80

5.1. Precisão dos implantes: refinamento conforme PPSCs e validação histológica ___ 80

5.2. Atividade oscilatória talâmica e cortical conforme a injeção das drogas ___ 82

5.3. A atividade colinérgica prévia à EAF favoreceu uma PLD tardia no CPFm _ 85

5.4. A atividade colinérgica prévia à EBF suprimiu uma DLD estável no CPFm __ 85

5.5. A aplicação dos agonistas, por si só, não afetou os PPSCs em longo prazo ___ 89

5.6. As mudanças nos PCLs foram correlacionadas com o pico da PLD pré-frontal ___ 89

5.7. Experimento complementar: facilitação pré-sináptica por pulsos pareados ___ 91

6. Discussão 94

6.1. Possível envolvimento de receptores NMDA

6.2. Possível interação entre receptores colinérgicos e glutamatérgicos ___ 98

6.3. Ativação colinérgica no contexto da anestesia: imitando o sono paradoxal? ___ 102

7. Considerações finais 
O presente estudo tratou de um circuito talamocortical não dominado previamente por nosso grupo de pesquisa, tanto em termos técnicos quanto teóricos. Além disto, testamos efeitos da nicotina sobre a plasticidade sináptica neste circuito, e o contexto teórico da droga também era pouco conhecido por nós. Isto exigiu a busca bibliográfica que revisamos a seguir. Pretende-se, com a revisão, subsidiar a interpretação de nossos achados eletrofisiológicos e discussões.

O encéfalo vertebrado é coberto pelo córtex, cujas células são organizadas em camadas $^{1}$. Particularmente, mamíferos preservam porções corticais primitivas (córtex piriforme e formação hipocampal) compostas por não mais que três camadas, mas também mostram derivação de um grande manto com seis camadas, referido como neocórtex ${ }^{1}$. A maioria das terminações sinápticas que chegam ao córtex cerebral têm origem nele mesmo ${ }^{1,2}$. A comunicação entre áreas corticais distantes é mediada por neurônios piramidais, cujas projeções são excitatórias e percorrem a substância cinzenta ou vias axonais como o corpo caloso ${ }^{1,3}$. Esta rede de comunicação remota se soma a conexões entre neurônios piramidais vizinhos, através de ramificações colaterais de seus axônios ${ }^{1,3}$. Por fim, interneurônios inibitórios e neurônios estrelados excitatórios formam malhas locais, com projeções intralaminares e translaminares ${ }^{4,5}$.

Processos corticais de integração sensorial, consolidação de memórias e comando motor são fundamentados na riqueza de contatos corticocorticais ${ }^{1,2}$. Para que esta capacidade computacional se adeque continuamente às demandas do ambiente e do resto do organismo, o córtex recebe aferências menos numerosas provenientes de regiões subcorticais $^{6,7}$. A influência subcortical é parcialmente representada por inervações difusas oriundas do tronco encefálico, hipotálamo e prosencéfalo basal, cujos neurotransmissores (monoaminas, peptídeos e acetilcolina) exercem uma modulação global ${ }^{6}$. A ação combinada destes neuromoduladores induz um espectro de estados de atividade cortical, variando do sono ao alerta ${ }^{8,9}$. Porém, a principal fonte de aferências ao córtex reside no tálamo, que, sendo também sujeito à modulação ascendente, é corresponsável pelo contínuo de estados funcionais que o córtex pode assumir ${ }^{7,10,11}$. Embora os contatos talamocorticais representem menos de $10 \%$ do total de sinapses no córtex, sugere-se que eles sejam individualmente mais eficazes que os contatos corticocorticais, uma vez que a maioria dos terminais présinápticos talamocorticais são maiores, ricos em mitocôndrias e localizados em porções basais dos dendritos piramidais ${ }^{7,11}$. Além disto, os axônios talamocorticais têm diâmetro 
maior e são mais mielinizados, o que explica a maior rapidez com que seus potenciais de ação se propagam ${ }^{12}$. Conjuntamente, estas características tornam a comunicação entre tálamo e córtex mais ágil e objetiva do que a comunicação corticocortical ${ }^{12}$.

\subsection{Circuitos talamocorticais e corticotalâmicos}

\subsubsection{Anatomia e ontogenia}

Tálamo (significado grego para câmara) consiste num conjunto compacto de núcleos, bilateralmente organizados ao redor do terceiro ventrículo (linha média) e posicionados no centro do encéfalo ${ }^{13}$. O tálamo pode ser dividido em duas partes: tálamo dorsal, geralmente subdividido em 15 núcleos, e tálamo reticular (TRt) ${ }^{13}$. O TRt tem o formato de um concha envolvendo parte do tálamo dorsal, cobrindo sua superfície anterior, ventral e lateral ${ }^{13,14}$.

Os axônios talamocorticais, que provêm dos núcleos do tálamo dorsal, são projeções glutamatérgicas que se dirigem ao córtex via cápsula interna, recebendo projeções piramidais glutamatérgicas em retorno ${ }^{14}$. Durante 0 desenvolvimento embrionário mamífero, as futuras projeções talamocorticais e corticotalâmicas migram umas em direção às outras, à medida que os cones de crescimento axonais navegam em meio a pistas moleculares na matriz entre o telencéfalo e diencéfalo ${ }^{15}$. Propõe-se que a partir do encontro dos cones de crescimento em suas migrações opostas, os axônios talâmicos e corticais passem a se apoiar mutuamente por interações moleculares, o que ajudaria a guiar o resto de suas trajetórias até o fechamento das alças tálamo-córtico-talâmicas ${ }^{15}$. Os neurônios talamocorticais têm árvore dendrítica estrelada e totalizam cerca de $70 \%$ dos neurônios que compõem os núcleos do tálamo dorsal em primatas e felinos. Os demais neurônios são interneurônios GABAérgicos intrínsecos ${ }^{14}$. A porcentagem de interneurônios talâmicos tende a ser menor em mamíferos mais simples. De fato, em roedores estes interneurônios só estão presentes no núcleo geniculado lateral, correspondente ao sistema visual, sugerindo que quanto mais desenvolvida a rede de inibição intrínseca, maior a capacidade de

processamento em nível talâmico ${ }^{16,17}$. 
Diferentemente do tálamo dorsal, o TRt é formado somente por neurônios fusiformes GABAérgicos, cujos axônios são direcionados exclusivamente aos demais núcleos talâmicos, terminando em contatos simétricos sobre interneurônios (quando presentes) e neurônios talamocorticais ${ }^{14,18}$. As projeções do TRt invadem o tálamo dorsal perpendicularmente, culminando em campos receptivos com diferentes graus de sobreposição, dependendo dos núcleos inervados ${ }^{18}$. Em sua anatomia estreita, o TRt é atravessado pelos axônios talamocorticais, que no trajeto em direção ao córtex deixam ramos colaterais excitatórios dentro do TRt, fechando alças de retroalimentação. No caminho contrário, a maioria dos axônios corticotalâmicos cruzam o TRt e também deixam ramos colaterais excitatórios dentro dele ${ }^{14,18}$. Apesar de receber os terminais corticotalâmicos colaterais, o TRt não devolve projeções ao córtex ${ }^{14,18}$. Conjuntamente, as projeções talamocorticais, neurônios do TRt e axônios corticotalâmicos organizam-se numa segregação topográfica que corresponde ao pareamento entre núcleos do tálamo dorsal e respectivos campos receptivos corticais ${ }^{13}$. Assim, a organização das projeções eferentes e aferentes talâmicas reflete, aproximadamente, as fronteiras citoarquitetônicas que definem as áreas corticais, ainda que com certas variações dependendo do núcleo talâmico ${ }^{14,18}$.

A descoberta dos elementos básicos dos circuitos talâmicos deve ser creditada ao histologista espanhol Santiago Ramón y Cajal (século XIX) ${ }^{19,20}$, ainda que sua contribuição acerca da histologia cortical seja mais famosa ${ }^{14}$. O detalhamento tecidual fornecido por Cajal foi seguido pela delineação de núcleos talâmicos pelo patologista alemão Franz Nissl no começo do século $\mathrm{XX}^{21}$, cuja nomenclatura proposta é válida até hoje ${ }^{14}$. Posteriormente, em $1938^{22}$, o neurofisiologista espanhol Rafael Lorente de Nó descreveu os núcleos do tálamo dorsal, propondo sua classificação em dois grupos de acordo com a distribuição das projeções talamocorticais: (1) núcleos específicos, com campos de terminações densos restritos a uma única área cortical; e (2) núcleos não-específicos, com ramificações mais esparsas, espalhadas por diferentes áreas corticais contíguas ou próximas ${ }^{7}$. Mais recentemente, o estadunidense Miles Herkenham (1980) ${ }^{23}$ aperfeiçoou a classificação de Lorente de Nó, propondo que os núcleos do tálamo dorsal devem ser categorizados conforme as camadas corticais que abrigam suas terminações ${ }^{7}$. Na classificação de Herkenham, os núcleos específicos, com terminações preferenciais nas camadas III e IV, tiveram seu agrupamento mantido. Por outro lado, os núcleos não-específicos foram subdivididos em intralaminares, de projeção preferencial às camadas profundas $\mathrm{V}$ e $\mathrm{VI}$, e 
paralaminares, com terminações que incluem a camada I mas também outras camadas, dependendo da área cortical. Exemplos de núcleos específicos são aqueles que servem como estação sensorial às áreas corticais primárias ${ }^{7}$. Em contraste, a maioria dos núcleos intralaminares e paralaminares projeta-se a áreas corticais associativas ou contribui com entradas complementares a áreas corticais primárias ${ }^{7,24}$.

Nas etapas avançadas do desenvolvimento talamocortical, acontece um refinamento das ramificações terminais talâmicas dentro do córtex ${ }^{25}$. Num primeiro momento, as ramificações são modeladas com base em pistas moleculares correspondentes às camadas corticais. Em seguida, um refinamento morfológico adicional depende de mecanismos de plasticidade sináptica, num processo dinâmico de adição e eliminação de conexões conforme os padrões de atividade elétrica gerados por experiência sensorial e cognitiva ${ }^{25}$. A maioria dos mecanismos de plasticidade estrutural nos terminais talamocorticais se restringe ao início da vida pós-natal ${ }^{11,26}$. Mesmo assim, vários circuitos talamocorticais continuam sensíveis à indução de plasticidade sináptica até a vida adulta ${ }^{27,28}$, especialmente sob facilitação de neuromoduladores como histamina e acetilcolina ${ }^{29-33}$.

\subsubsection{Fisiologia}

Tendo em vista que a organização talâmica reflete topograficamente as áreas corticais, e que entradas ao tálamo originadas na periferia sensorial ou outras partes do encéfalo também são segregadas, qual o propósito de haver uma estação entre as fontes de informações e o córtex? Não seria mais econômica uma transmissão direta das informações (a exemplo do sistema olfatório) ${ }^{13}$ Esta questão esteve aberta até os anos 1960, quando a microscopia eletrônica revelou que os terminais transmitindo informações periféricas aos núcleos talâmicos específicos não passam de uma minoria em relação ao total de terminais aferentes $^{13,34,35}$. Um caso exemplar é o do núcleo geniculado lateral, correspondente ao sistema visual. Numa atualização de sua ultraestrutura, mostrou-se que menos de $10 \%$ dos terminais sobre os neurônios talamocorticais provêm da periferia, no caso a retina, sendo os terminais restantes provenientes do TRt, interneurônios locais, tronco encefálico e fibras corticotalâmicas $^{36}$. Embora as aferências periféricas aos núcleos específicos sejam pouco 
numerosas, sua influência sobre os neurônios talamocorticais é alta. Afinal, seus terminais são grandes e contatam porções proximais dos dendritos, exercendo um poderoso efeito pós-sináptico à semelhança do que ocorre nos terminais talâmicos dentro do córtex ${ }^{37}$.

Neste sentido, Murray Sherman e Ray Guillery $(1998)^{38}$ propuseram a categorização das aferências ao tálamo em dois tipos: drivers, ou condutoras, e moduladoras. As entradas condutoras carregariam a informação principal, enquanto as moduladoras se responsabilizariam pelo processamento da informação. A posição do tálamo no centro do encéfalo, bem como sua anatomia nodal e compacta, favoreceriam a reunião dos dois tipos de entradas. Nos núcleos não-específicos, as entradas condutoras viriam de projeções corticotalâmicas da camada V, enquanto as moduladoras seriam fornecidas pela camada VI, de acordo com critérios da morfologia sináptica ${ }^{38}$. Guillery e Sherman utilizaram como exemplo de tálamo não-específico a região pulvinar para proporem esta diferenciação das entradas corticotalâmicas. Talvez seja precipitado extrapolar o padrão para todos os núcleos não-específicos, dada a sua heterogeneidade e mapeamento incompleto das aferências ${ }^{24}$. De qualquer forma, considerando-se que muitos núcleos não-específicos se comunicam com áreas corticais de ordem superior, é possível que boa parte dos processos associativos corticais tire proveito da regulação nodal talâmica, similarmente ao que ocorre nos sistemas sensoriais primários ${ }^{37}$. Este pode ser o caso do núcleo talâmico mediodorsal (Tmd), um de nossos principais objetos de estudo. Por fim, quanto aos núcleos talâmicos relacionados a áreas corticais motoras, por exemplo o complexo de núcleos anteriores ventrais e laterais que recebem entradas do cerebelo e estriado, o processamento talâmico participa da antecipação e automonitoramento de comandos motores ${ }^{39,40}$.

Portanto, o tálamo congrega entradas periféricas, inibição intrínseca, neuromodulação ascendente e retroalimentação corticotalâmica, ajudando a formar experiências coerentes a partir de eventos sensoriais e cognitivos distintos. Porém, estas operações refinadas estão subjacentes a padrões mais globais da atividade talamocortical, que estão na base dos estados de consciência. Neste ponto de vista panorâmico, as células talamocorticais atuam como regentes da atividade oscilatória prosencefálica em diferentes níveis de reverberação excitatória junto ao córtex, e sob constante regulação do TRt e vias neuromoduladoras ascendentes ${ }^{41}$. A capacidade talâmica de reger a atividade oscilatória tem origem em propriedades eletrofisiológicas peculiares dos neurônios talamocorticais. Tais propriedades começaram a ser elucidadas a partir dos anos 1980, quando dois grupos 
de pesquisa norte-americanos, um liderado pelo colombiano Rodolfo Llinás (inicialmente usando fatias talâmicas cultivadas in vitro, extraídas de cobaias ${ }^{42,43}$ ) e outro pelo romeno Mircea Steriade (inicialmente usando gatos in vivo ${ }^{44,45}$ ), paralelamente demonstraram que os neurônios talamocorticais se comportam em dois estados funcionais: o modo tônico, característico da vigília e sono paradoxal, e o modo de salvas (burst firing), característico do sono de ondas lentas. Esta dualidade funcional talamocortical é filogeneticamente conservada, sendo encontrada na maioria dos grupos vertebrados ${ }^{41,46,47}$.

Em seu estado funcional intrínseco, os neurônios talamocorticais repetem sequencialmente salvas de potenciais de ação (3-8 potenciais de ação a 250-500 Hz dentro de cada salva, totalizando $~ 8-30 \mathrm{~ms}$ ) que se alternam com períodos de hiperpolarização de $\sim 60 \mathrm{~ms}$ a $\sim 2 \mathrm{~s}$, formando uma alternância salva/hiperpolarização na frequência principal de 0,5-4 Hz $\mathrm{Hz}^{42,43,48,49}$. Os neurônios talamocorticais permanecem neste modo cíclico quando os potenciais de membrana de seus dendritos e pericários são mantidos mais negativos do que $-70 \mathrm{mV}$. Sob o potencial de membrana hiperpolarizado, canais iônicos permeáveis a $\mathrm{Ca}^{2+}$ (tipo T) presentes nas células talamocorticais permitem influxos despolarizantes autoregenerativos justamente na frequência de $0,5-4 \mathrm{~Hz}^{42,43,50}$. Tais despolarizações dependentes de $\mathrm{Ca}^{2+}$ acabam propiciando os potenciais de ação clássicos (dependentes de $\mathrm{Na}^{+}$e corrente retificadora de $\mathrm{K}^{+}$) que compõem as salvas individuais ${ }^{51}$. A hiperpolarização sustentada que mantém o modo funcional cíclico talamocortical é atribuída principalmente às projeções GABAérgicas do TRt. O estado funcional intrínseco das células do TRt também é caracterizado por atividade cíclica, porém suas salvas $(100-400 \mathrm{~Hz})$ são mais duradouras (centenas de milissegundos) do que as emitidas pela células talamocorticais, sendo ativadas principalmente pelos ramos colaterais provenientes dos axônios corticotalâmicos ${ }^{48,52,53}$. Tendo em vista que tanto os axônios corticotalâmicos quanto talamocorticais deixam ramos axonais dentro do TRt, a atividade cortical e talâmica em $0,5-4 \mathrm{~Hz}$ realimenta as salvas longas do TRt, que por sua vez mantém elevado o suprimento de GABA ao tálamo dorsal, sustentando, assim, sua hiperpolarização ${ }^{18}$. Isto fecha um sistema de retroalimentação que estabiliza as ondas lentas $(0,5-4 \mathrm{~Hz})$ do sono profundo e anestesia, e também contribui para ondas em fusos ( $10-15 \mathrm{~Hz}$ ) típicas dos estágios iniciais do sono ${ }^{41,54}$. Por si só, as alças de retroalimentação mantêm o ciclo de salvas em circuitos talamocorticais separados, porém sem que os circuitos individuais sincronizem suas salvas, uma vez que há poucas conexões diretas entre os neurônios talamocorticais ${ }^{18}$. Diferentemente, as células do TRt possuem, 
entre si, conexões dendrodentríticas que sincronizam suas atividades ${ }^{18}$. Assim, as interações laterais entre células do TRt, em conjunto com a sobreposição de suas terminações axonais, espalham a sincronização pelo tálamo dorsal, que por sua vez reverbera a sincronização junto ao córtex ${ }^{18,54}$. A sincronização robusta em larga escala é resistente à transmissão de informações sensoriais, o que funcionalmente desconecta o prosencéfalo em relação aos estímulos ambientais levando-o à inconsciência ${ }^{41}$. A atividade em salvas também ocorre, eventualmente, no estado acordado em instantes de desatenção ou sonolência, porém com grau menor de sincronização ao longo dos diferentes domínios talamocorticais ${ }^{41,54}$.

Se por um lado a atividade oscilatória lenta serve como barreira à percepção consciente e atenção, por outro a sincronização prosencefálica inerente a ela pode explicar sua própria reversibilidade. Em outras palavras, tamanha sincronização é, ao mesmo tempo, robusta e sensível à transmissão talamocortical efetiva de sinais ambientais, contanto que os estímulos sensoriais sejam suficientemente salientes para despertar o sistema, retirando-o de sua ciclicidade ${ }^{55}$. De fato, argumenta-se $e^{56,57}$ que as oscilações lentas potencializam as respostas corticais a estímulos ambientais despertadores, o que pode deflagrar rápida migração ao estado oscilatório em ondas rápidas. O estado de ondas rápidas, ou modo tônico de disparos, é a antítese da atividade em salvas, e ocorre quando o potencial de membrana talamocortical está próximo a, ou mais positivo que, $-60 \mathrm{mV}^{54}$. Ao mesmo tempo em que desativa as correntes de cálcio mediadas pelos canais do tipo $\mathrm{T}$, o potencial em cerca de $-60 \mathrm{mV}$ aproxima-se do limiar para potenciais de ação, porém sem que esta aproximação esteja atrelada a qualquer ciclicidade lenta e regular. Isto possibilita padrões irregulares de trânsito iônico através da membrana dendrítica talamocortical, que por sua vez permitem codificações representadas por trens de potenciais de ação, com frequências variando entre $\sim 20-80 \mathrm{~Hz}$ (banda beta-gama) ${ }^{54}$. As entradas sinápticas que mais se aproveitam da permissividade à transferência fiel de informações são as glutamatérgicas. Elas são representadas pelas aferências sensoriais ou fibras corticotalâmicas ${ }^{54}$, e sua neurotransmissão no tálamo é mediada tanto por receptores ionotrópicos (AMPA e NMDA) quanto metabotrópicos. No estado tônico, as vias corticotalâmicas continuam a influenciar colateralmente o TRt, porém sem a regularidade necessária ao espalhamento de sincronia talâmica ${ }^{18,54}$. Assim, na ausência das salvas, a inibição exercida pelo TRt passa a participar de refinamentos locais da função talâmica sob o estado acordado, em conjunto com interneurônios do tálamo dorsal, quando presentes ${ }^{18,54}$. Aliás, a coordenação da atividade 
oscilatória entre diferentes domínios talamocorticais (ligação temporal, conforme Paré e Llinás ${ }^{58}$ ) pode ser um dos mecanismos básicos do direcionamento atentivo na vigília.

Apesar de as vias talamocorticais e corticotalâmicas participarem da manutenção da atividade tônica, ela não se sustentaria sem a modulação ascendente colinérgica (proveniente dos núcleos laterodorsal e pedunculopontino do tegmento mesencefálico, respectivamente LDT e PPT), histaminérgica (núcleo tuberomamilar do hipotálamo), noradrenérgica (locus coeruleus) e serotoninérgica (núcleos da rafe) ${ }^{59-65}$. Basicamente, estes neurotransmissores promovem mudanças subliminares no potencial de membrana das células do tálamo dorsal e TRt, regulando a condutância de repouso de $\mathrm{K}^{+}$ou as oscilações dependentes de $\mathrm{Ca}^{2+}$ subjacentes às salvas $^{54}$. Por exemplo, a ativação de receptores colinérgicos muscarínicos, noradrenérgicos $\alpha_{1}$ e histaminérgicos $H_{1}$ de neurônios talamocorticais reduz a condutância de $\mathrm{K}^{+}$, promovendo a despolarização e o modo tônico. Opostamente, receptores noradrenérgicos $\beta$ ou histaminérgicos $\mathrm{H}_{2}$ potencializam as oscilações catiônicas dependentes de hiperpolarização, o que favorece a ocorrência de salvas $^{54}$. Como se vê, um mesmo neurotransmissor pode exercer efeitos distintos sobre os neurônios talamocorticais, dependendo dos subtipos de receptores recrutados. Particularmente, tanto receptores colinérgicos nicotínicos quanto muscarínicos promovem despolarização, porém os efeitos nicotínicos são mais rápidos e menos duradouros (dada a natureza ionotrópica) e os efeitos muscarínicos são mais lentos e duradouros (dada a mediação metabotrópica) ${ }^{54}$. Estas especificidades nos dão noção da miríade de processos talâmicos que resultam da ação combinada dos centros neuromoduladores. Além disto, os neuromoduladores (incluindo-se, aí, a influência dopaminérgica da área tegmental ventral, ou $\mathrm{ATV}^{66}$ ) também regulam o potencial de membrana celular de diferentes áreas corticais ${ }^{54}$, o que contribui ao espectro de estados funcionais do prosencéfalo no ciclo sono-vigília.

Anomalias na regulação aferente da função talâmica podem gerar desarmonia quanto ao nível de sincronização entre diferentes circuitos talamocorticais. Assim, conjuntos particulares de células talâmicas podem se prender ao modo de salvas de maneira anormal, em meio a um contexto prosencefálico tônico ${ }^{67}$. Estas disfunções talâmicas, em suas variadas formas e combinações, contribuem para importantes transtornos neuropsiquiátricos, como psicoses ${ }^{12,68}$, déficits de atenção ${ }^{69}$ e síndromes de dor central ${ }^{67}$. Particularmente, determinados sintomas psicóticos têm sido associados a problemas na maneira com que o prosencéfalo monitora a si mesmo, o que pode ser explicado por 
disfunções nos disparos corolários ${ }^{70}$. Disparos corolários são padrões de atividade num dado circuito talamocortical que se antecipam a padrões de atividade equivalentes nos circuitos corticocorticais relacionados, como se as fibras talâmicas tirassem proveito de sua propagação rápida de sinais para anunciarem aos circuitos corticocorticais sobre o que está por vir ${ }^{39,40}$. Propõe-se que este sistema de antecipação seja importante para o senso de subjetividade, e que a patologia talâmica sob as psicoses ajude a explicar a desarmonia talamocortical e, consequentemente, as alucinações e a sensação de que os próprios pensamentos estão fora de controle ${ }^{70}$. Alternativamente, sincronias anômalas em regiões corticais podem reverberar junto aos circuitos talâmicos, generalizando paroxismos por todo o encéfalo ${ }^{67,71}$. Este pode ser o caso da epilepsia do lobo temporal (ELT). Embora a ELT seja tradicionalmente atribuída a focos não-talâmicos (por exemplo, amígdala e hipocampo), sua amplificação parece depender das interações entre estes focos e o tálamo ${ }^{72}$. Conforme as crises se repetem, a amplificação de paroxismos afetaria gradualmente regiões distantes dos focos, e isto poderia explicar algumas das comorbidades psiquiátricas da $\mathrm{ELT}^{73}$. Além disto, acidentes vasculares atingindo núcleos talâmicos podem prejudicar as funções cognitivas processadas pelas áreas corticais que recebem as projeções de tais núcleos ${ }^{74}$.

\subsection{Córtex pré-frontal em sua conectividade com o tálamo}

O repertório comportamental mamífero reflete a diversidade de nichos ocupados por esta classe de animais. Assim, pode-se esperar que seus encéfalos possuam disparidades anatômicas e funcionais correspondentes à diversidade de pressões ambientais sofridas por cada grupo. Realmente, existem variações quanto a circuitos locais e importância relativa de modalidades sensoriais. Por exemplo, o grande desenvolvimento do sistema visual primata contrasta com a relativa simplicidade do sistema visual de roedores ${ }^{75}$. Por outro lado, o córtex somatossensorial de roedores reserva importante espaço para a representação das vibrissas, o que não ocorre no encéfalo primata ${ }^{76}$. Apesar das particularidades sensoriais, os processos cognitivos posteriores à deteç̧ão sensorial são essencialmente uniformes ao longo da classe e estão na base da flexibilidade comportamental ${ }^{77}$. 
De fato, a detecção sensorial não basta para a flexibilidade comportamental. Também é preciso filtrar informações relevantes a partir da gama de estímulos ambientais e corporais, respeitando-se a capacidade de processamento encefálico. Uma vez selecionadas, as informações relevantes devem ser interpretadas em comparação com a experiência passada, ora reforçando-se determinadas memórias, ora remodelando-as. Tal interpretação deve ser orientada conforme o teor emocional da experiência presente e das memórias evocadas, prevendo-se a probabilidade de sucesso da futura ação comportamental. Finalmente, para que todo o processamento se converta em saída comportamental, deve-se emitir uma resposta potencialmente apropriada àquela situação ${ }^{77}$. Estas etapas de processamento correspondem a conceitos bem conhecidos da neuropsicologia, que incluem atenção, memória de trabalho e tomada de decisões ${ }^{78}$. Estes processos, tão rápidos quanto centenas de milissegundos, precisam congregar informações de múltiplas fontes. Isto implica na necessidade de um centro executivo, que também seja capaz de concatenar sequências comportamentais conforme estratégias aprendidas previamente ${ }^{78}$.

Atualmente, é bem aceito que o componente executivo corresponde ao córtex préfrontal (CPF), e mais especificamente ao córtex pré-frontal dorsolateral (CPFdl) de primatas. A ideia começou a se fortalecer a partir de 1970, quando a experimentação comportamental dedicada ao CPFdl se acelerou. Experimentos farmacológicos, eletrofisiológicos e de lesão avaliaram estimação temporal, retenção de respostas, programação motora, discriminação condicional, memória de trabalho e comportamento social em primatas não-humanos. Levando-se em conta pioneirismo e, ao mesmo tempo, quantidade de publicações, nosso entendimento do CPFdl primata como componente executivo deve ser creditado a autores como John Stamm ${ }^{79,80}$, Patricia Goldman-Rakic ${ }^{81,82}$, Kisuo Kubota ${ }^{83,84}$, Masataka Watanabe ${ }^{85,86}$, Joaquín Fuster ${ }^{87,88}$ e Shintaro Funahashi ${ }^{89,90}$. Paralelamente, outros autores, como Bryan Kolb ${ }^{91,92}$, Francisco Mora ${ }^{93,94}$ e Raymond Kesner ${ }^{95,96}$, utilizaram estratégias semelhantes em ratos, ao suporem que estes animais portariam um córtex pré-frontal homólogo ao CPFdl primata. Embora as investigações em primatas não-humanos e ratos tenham progredido concomitantemente, o debate sobre a presença de um córtex préfrontal em roedores esteve aberto até recentemente ${ }^{97}$, quando o confronto entre estudos comportamentais e critérios anatômicos tornou plausível a existência da homologia.

Muito antes deste debate, Rose e Woolsey $(1948)^{98}$ haviam feito um estudo de neuroanatomia comparativa em coelhos, ovelhas e gatos, indicando que seu córtex 
orbitofrontal poderia ser definido, simplesmente, com base na conexão recíproca com o tálamo. Trata-se do núcleo talâmico mediodorsal (Tmd), cujas projeções viriam a servir como critério exclusivo para delimitar o CPFdl primata ${ }^{97}$. Com o avanço da neuroanatomia de traçamento, observou-se que, na verdade, as terminações do Tmd no CPFdl se sobrepõem a terminações provenientes de outros núcleos talâmicos, especialmente os ventrais da linha média (reuniens e rombóide) ${ }^{99}$. Além disto, o Tmd também envia aferências a outros córtices, como o pré-motor, motor e parietal ${ }^{100,101}$. Apesar do refinamento neuroanatômico, o Tmd continua a ser considerado como a principal fonte de entradas diencefálicas ao CPFdl. Neste sentido, a proposta mais recente de delimitação do CPFdl leva em conta a densidade de terminações do Tmd em conjunto com a conectividade corticocortical ${ }^{97}$. Com estes critérios mais parcimoniosos, estabeleceu-se com mais rigor a área do córtex pré-frontal de roedores que seria homóloga ao CPFdl primata: o córtex pré-frontal medial (CPFm) ${ }^{97}$.

\subsubsection{Estudos em roedores}

O contexto aminérgico e colinérgico regula o estado eletroquímico de todo o prosencéfalo, produzindo variações da atividade oscilatória. A atividade oscilatória, no entanto, não é diretamente executada pelas vias moduladoras, mas pela interface bidirecional entre o tálamo e o córtex. Ora, as diferentes áreas corticais processam funções sensoriais e cognitivas relativamente segregadas, e tal segregação reflete a organização topográfica da radiação talamocortical. Portanto, relembrando-se que o principal parceiro talâmico do CPFm é o Tmd, é plausível que as atividades do CPFm e Tmd sejam interdependentes, o que implicaria no compartilhamento de funções cognitivas.

De fato, este compartilhamento foi demonstrado por análises comportamentais envolvendo lesão, estimulação farmacológica, ou atividade eletrofisiológica do CPFm e/ou Tmd. Mostrou-se que lesões ao CPFm ou Tmd prejudicam o desempenho em tarefas que exigem retenção e alternância de respostas, representadas por entradas aos braços de um labirinto em T ou pressões a barras retráteis ${ }^{102-105}$. Efeitos comportamentais similares foram obtidos aplicando-se antagonistas de receptores glutamatérgicos no CPFm ou agonistas GABAérgicos no $\mathrm{Tmd}^{106,107}$. Estudos de lesão ou estimulação farmacológica também 
evidenciaram a participação do CPFm e Tmd na evocação de estratégias previamente aprendidas $^{108}$, e na troca de estratégias conforme demandas da tarefa ${ }^{109}$. A inativação permanente ou reversível do CPFm e Tmd foi mostrada por prejudicar a evocação de memórias aversivas ${ }^{110,111}$, extinção tátil ${ }^{112}$, e auto-estimulação do CPFm ${ }^{113,114}$.

Num experimento com labirinto radial e imageamento da captação cerebral de glicose, Sarter et al. ${ }^{115}$ mostraram que a exploração do labirinto induz aumento da atividade metabólica do CPFm e Tmd, e que o aumento é maior nos sujeitos novatos. Coerentemente, Gabriel e Orona ${ }^{116}$ observaram que padrões de atividade neuronal unitária (potenciais de ação) no CPFm e Tmd sofrem mudanças no decorrer da aprendizagem em discriminação condicional. Oyoshi et al. ${ }^{117}$ também se interessaram pela atividade unitária do Tmd e sua evolução conforme a aprendizagem. Utilizando ratos privados de água e mecanicamente imobilizados, eles quantificaram respostas condicionadas (lamber bica de água) eliciadas pela apresentação de estímulos visuais e sonoros. Os autores registraram potenciais de ação em duas porções distintas do Tmd: lateral ou rostromedial, e observaram seu padrão de atividade em relação à sequência de estímulos condicionados e respectivas respostas. Os resultados indicaram que os padrões de atividade no Tmd lateral se anteciparam especificamente às respostas condicionadas, enquanto os padrões registrados no Tmd rostromedial se relacionaram temporalmente com os estímulos condicionados. Além disto, a atividade do Tmd rostromedial foi sensível ao progresso do condicionamento e a diferentes intervalos de retenção aplicados entre o estímulo condicionado e a liberação de água.

Embora a informação quanto às divisões do Tmd pareça muito específica, ela teve consequências diretas sobre as coordenadas estereotáxicas usadas neste doutorado. Segundo o mapeamento das aferências ao CPFm de ratos, atualizado em 2007 por Hoover e Vertes $^{118}$, o Tmd rostromedial concentra a maioria das células de projeção à parte ventral do CPFm, dividida nas áreas infra-límbica (IL) e pré-límbica (PrL). Por sua vez, o Tmd lateral envia projeções preferenciais a: (1) córtex cingulado anterior (CCa), correspondente à parte dorsal do CPFm relacionada ao controle pré-motor; e (2) córtex agranular medial (CAm), que faz parte do córtex motor (Fig. 1) ${ }^{118,119}$. Dado o nosso interesse quanto aos aspectos cognitivos da função pré-frontal, o detalhamento regional do Tmd teve importância prática, de modo que visaríamos a parte rostromedial deste núcleo nos experimentos. De qualquer forma, é relevante que Oyoshi et al. ${ }^{117}$ tenham dissociado um "Tmd motor" de um "Tmd sensorial e cognitivo", e que os campos de projeção das duas partes do Tmd correspondam, 
respectivamente, à região motora (dorsal) e à região associativa (ventral) do CPFm. Mais interessante ainda é notar que há mais projeções corticocorticais do CPFm ventral em direção ao CPFm dorsal e córtex motor do que o contrário (Fig. 1) ${ }^{118}$. De certa forma, este padrão anatômico insinua a funcionalidade pré-frontal: processamento cognitivo que prepara a saída comportamental ${ }^{120}$. Tendo em vista o caráter condutor ${ }^{38}$ da comunicação talamocortical, bem como a rapidez com que seus potenciais de ação se propagam ${ }^{12}$, o Tmd pode ter participação fundamental na tomada de decisões e antecipação motora, embora estas funções sejam, popularmente, mais atribuídas ao CPFm.
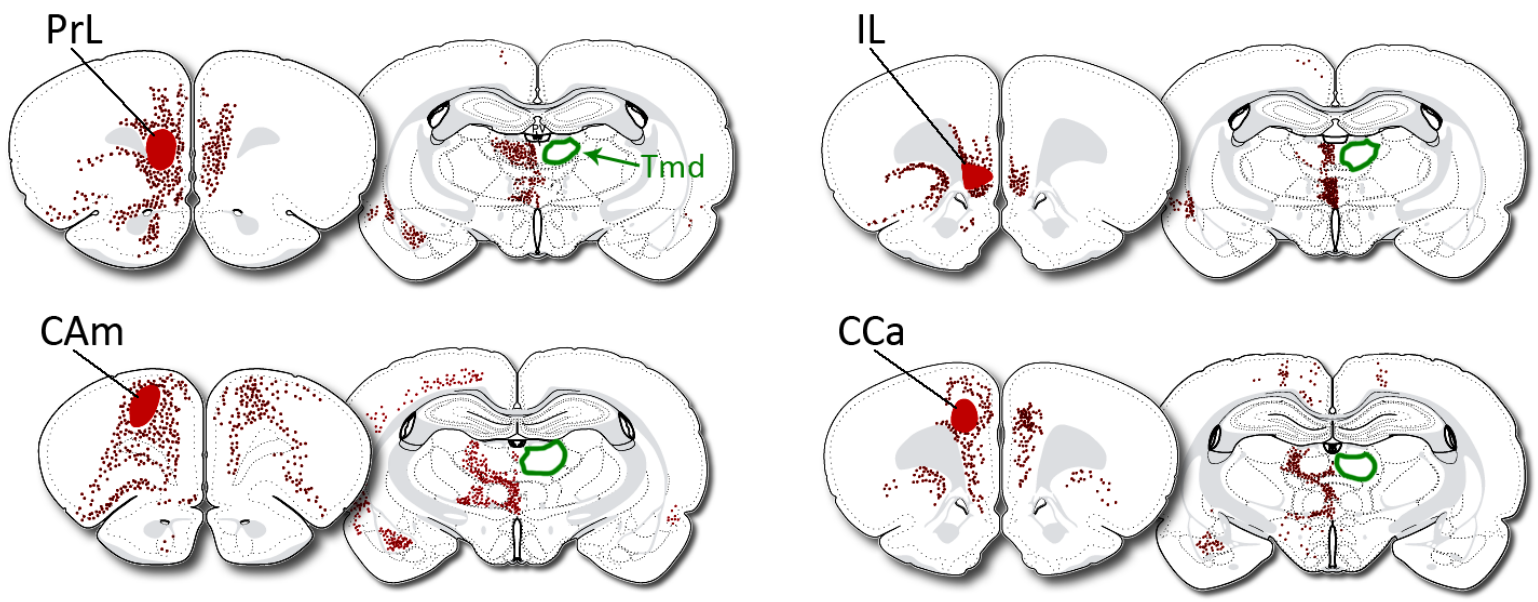

Figura 1. Mapa parcial de aferências talâmicas ao CPFm e córtex motor medial, identificadas por traçador axonal retrógrado (extraído de Hoover e Vertes, 2007) ${ }^{118}$. Apontam-se quatro sítios que receberam injeção do traçador (áreas vermelhas): PrL, IL, CAm e CCa. Os pontos vermelhos espalhados indicam a localização das células que se projetam aos sítios injetados. O Tmd contralateral, não marcado pelo traçador, está delimitado em verde, facilitando a visualização das eferências ipsilaterais conforme as dimensões e formato do núcleo. Note-se que PrL e IL, tidas como áreas mais associativas do $\mathrm{CPFm}^{120}$, recebem projeções preferenciais do Tmd rostromedial. Diferentemente, CAm (porção do córtex motor vizinha ao CPFm) e CCa (que concentra funções pré-motoras do CPFm) recebem projeções do Tmd lateral. O padrão anatômico corrobora a participação da atividade neuronal do Tmd rostromedial no condicionamento Pavloviano, e do Tmd lateral na antecipação de respostas condicionadas ${ }^{117}$.

Sabendo-se da regulação talâmica sobre os processos executivos pré-frontais, parece clara a importância de avaliar as respostas celulares do CPFm à estimulação elétrica do Tmd. Contudo, esta questão só foi abordada diretamente por uma linhagem de sete trabalhos (anos 1980-1990) publicados por um mesmo grupo francês, incluindo Anne-Marie Thierry, Jacques Glowinski e Thérèse Jay ${ }^{121-127}$. Em todos os experimentos eletrofisiológicos, foram usados ratos mantidos sob anestesia por doses periódicas do cloridrato de cetamina. Conjuntamente, os trabalhos exploraram a influência dopaminérgica ${ }^{121,126}$, noradrenérgica ${ }^{122}$, serotoninérgica ${ }^{123}$, e colinérgica ${ }^{127}$ sobre a atividade espontânea do CPFm 
e suas respostas à estimulação elétrica do Tmd. Em particular, três destes estudos ${ }^{124-126}$ confirmaram que a comunicação entre Tmd e CPFm é mediada por transmissão glutamatérgica. Em mais detalhes, Ferron et al. ${ }^{121}$ aplicaram trens de estímulos $(1-5 \mathrm{~Hz})$ à ATV (fonte de aferências dopaminérgicas) e obtiveram um bloqueio de $85 \%$ dos disparos espontâneos do CPFm por 109 ms. A maioria das células inibidas pela ATV eram excitáveis por pulsos aplicados no Tmd. Efeito inibitório similar foi mostrado por Mantz et al. ${ }^{123}$, porém com estimulação dos núcleos da rafe (fonte de projeções serotoninérgicas). Neste caso, somente $\sim 35-50 \%$ da atividade pré-frontal espontânea foi inibida por 75-82 ms, mas a inibição também incluiu as células excitáveis pelo Tmd. Outro trabalho de Mantz et al. ${ }^{122}$ testou uma estimulação longa $(20 \mathrm{~Hz}, 10$ s) do locus coeruleus (fonte de projeções noradrenérgicas), que promoveu inibição de $\sim 50 \%$ das unidades pré-frontais por $45 \mathrm{~s}$. Em contraste com a pré-modulação dopaminérgica e serotoninérgica, o efeito noradrenérgico de $45 \mathrm{~s}$ foi inócuo à evocação de repostas pelo Tmd. Finalmente, Gioanni et al. ${ }^{127}$ fizeram um estudo em três etapas. Na primeira, lesaram o Tmd unilateralmente para induzir regressão de seus axônios, sacrificaram os animais dentro de uma semana e processaram o CPFm para detecção autorradiográfica de receptores nicotínicos. Os resultados indicaram uma redução de $\sim 40 \%$ da marcação autorradiográfica no CPFm, mostrando que os terminais présinápticos do Tmd são ricos em receptores nicotínicos. Na segunda etapa, as respostas unitárias pré-frontais evocadas pelo Tmd foram testadas após aplicação de nicotina no CPFm. A nicotina facilitou as respostas. Na terceira etapa, os autores acompanharam a disponibilidade extracelular de glutamato no CPFm por meio de microdiálise, e observaram que a nicotina aumentou a liberação de glutamato.

Um cenário geral emergindo destes estudos é que todos os sistemas aminérgicos testados inibem temporariamente a atividade unitária espontânea do CPFm. No caso da préestimulação à ATV e núcleos da rafe, a atividade espontânea inibida inclui células excitáveis pelos terminais do Tmd. No entanto, a pré-estimulação do locus coeruleus inibe uma parcela da atividade espontânea que não é excitada pelos pulsos ao Tmd. Independentemente dos subtipos de receptores, isto significa que enquanto dopamina e serotonina temporariamente deprimem a atividade do CPFm como um todo, a noradrenalina destaca o sinal aferente ao reduzir o ruído corticocortical sem afetar diretamente a excitação talâmica. Uma influência direta sobre a excitação talâmica só é exercida pela pré-modulação 
colinérgica sobre o CPFm, o que se deve, pelo menos em parte, à ativação de receptores nicotínicos nos terminais do Tmd e consequente facilitação à liberação de glutamato.

$\mathrm{Na}$ mesma sequência de trabalhos franceses, os três estudos que melhor caracterizaram as respostas unitárias do CPFm à estimulação do Tmd foram os de Pirot et al. ${ }^{124-126}$ Os autores mostraram disparos unitários concentrados em torno de duas latências: 3,46 $\pm 0,05 \mathrm{~ms}$ (preferencialmente evocados por pulsos a $1 \mathrm{~Hz}$ ou menos) e 13,67 $\pm 0,22 \mathrm{~ms}$ (evocados por pulsos a 3-10 Hz). Os dois grupos de disparos foram referidos como respostas de latência curta e longa, respectivamente. As respostas de latência curta foram predominantemente encontradas na camada III do CPFm, enquanto as de latência longa foram mais prevalentes nas camadas V e VI. Com a ajuda de informações neuroanatômicas prévias $^{128}$, Pirot et al. ${ }^{124}$ concluíram que as respostas de latência curta refletiriam o verdadeiro recrutamento da via talamocortical Tmd-CPFm. Isto representa a estimulação dos corpos celulares do Tmd e, consequentemente, a propagação ortodrômica de potenciais de ação em direção a células pós-sinápticas piramidais da camada III do CPFm. Por outro lado, as respostas de latência longa resultariam da inevitável estimulação dos terminais axonais CPFm-Tmd, distribuídos em meio às células talâmicas que se projetam ao CPFm ${ }^{129}$. A estimulação destes terminais produziria potenciais de ação com propagação antidrômica ("contramão") em direção às próprias células de origem, localizadas nas camadas V-VI do CPFm. Por sua vez, as células corticotalâmicas das camadas V-VI projetam axônios bifurcados, formando um ramo remotamente direcionado ao Tmd e um ramo colateral curto, que inerva células piramidais vizinhas nas próprias camadas V-VI do CPFm. Ora, conforme outros trabalhos de Pirot et al. ${ }^{125,126}$ viriam a mostrar, as respostas de latência longa são farmacologicamente bloqueáveis. Isto significa que a propagação antidrômica dos axônios CPFm-Tmd também resulta em respostas pós-sinápticas do CPFm, uma vez que há recrutamento de ramos colaterais curtos, que por sua vez excitam células piramidais vizinhas nas camadas V-VI. A Figura 2 ilustra esta conectividade.

Pirot et al. ${ }^{124}$ fizeram um teste adicional para que a anatomia sob as respostas evocadas pelo Tmd fosse duplamente checada. Os autores observaram que a estimulação do Tmd contralateral ao CPFm registrado produziu as respostas de latência longa, mas não as de latência curta. De fato, a literatura ${ }^{130}$ já indicara projeções do CPFm (camadas V-VI) ao Tmd contralateral, mas não o contrário, o que permitiu a dissociação eletrofisiológica feita por Pirot et al. ${ }^{124}$ No segundo trabalho da série, Pirot et al. ${ }^{125}$ mostraram que ambas as 
categorias de respostas pré-frontais evocadas pelo Tmd dependem de transmissão glutamatérgica. Afinal, elas foram reduzidas por antagonistas de receptores AMPA (CNQX) e NMDA (APV), embora o antagonista de NDMA tenha reduzido somente as respostas de latência longa. No terceiro trabalho, Pirot et al. ${ }^{126}$ mostraram que a aplicação de dopamina exógena ou estimulação da ATV bloqueou somente as unidades de latência longa.

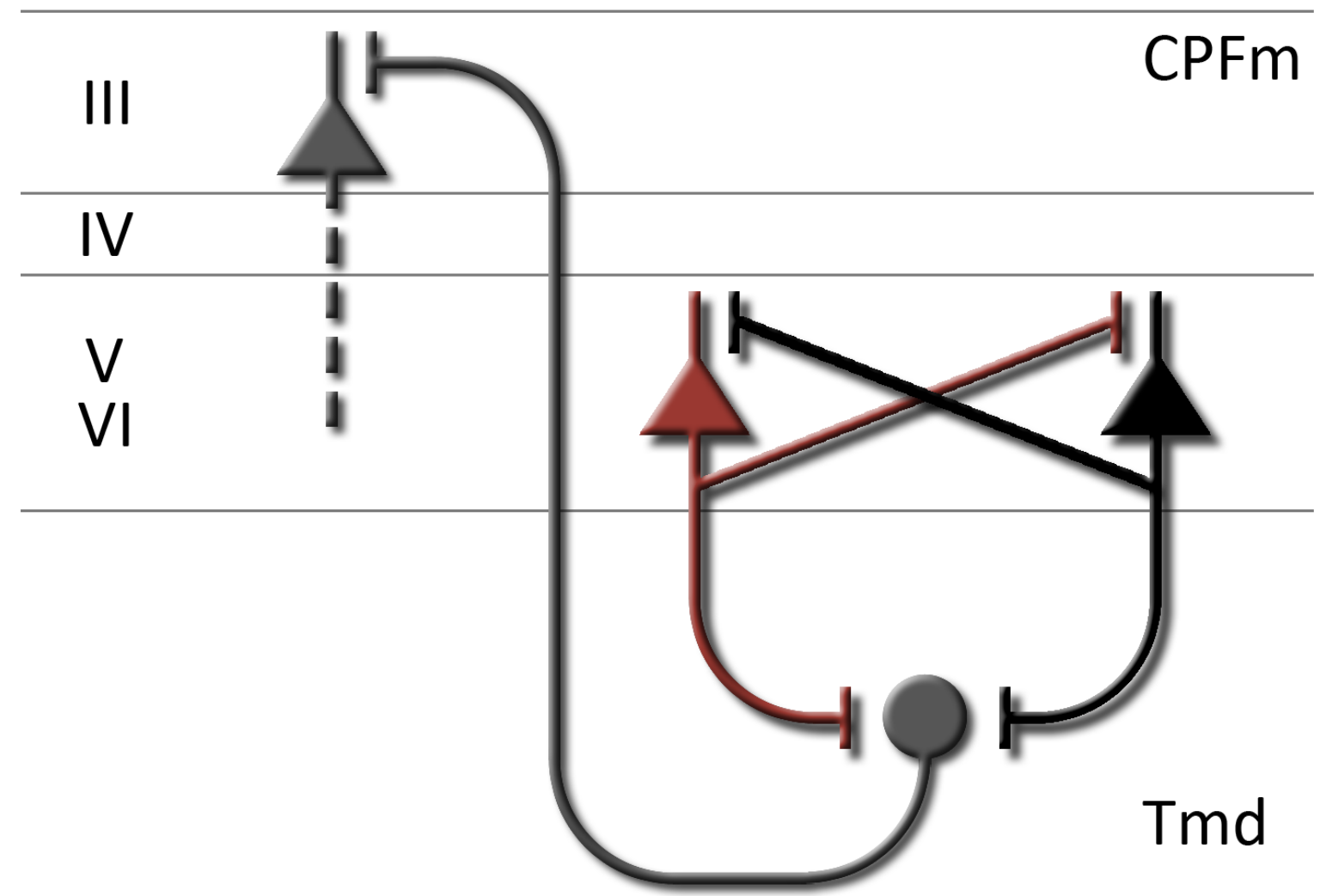

Figura 2. Diagrama simplificado do circuito Tmd-CPFm, destacando suas conexões excitatórias mais densas. As linhas horizontais de fundo delimitam as camadas III-VI do CPFm, onde estão localizadas as células piramidais envolvidas no circuito. Dendritos apicais de células piramidais da camada III são os principais recipientes de projeções excitatórias do Tmd, e os axônios corticocorticais destas células (linha tracejada) dirigem-se ao hemisfério oposto via corpo caloso ${ }^{129}$. Por sua vez, células piramidais das camadas V-VI enviam axônios corticotalâmicos excitatórios ao Tmd. Além disto, elas se comunicam reciprocamente através de ramos colaterais, que se originam dos axônios remotamente destinados ao $\mathrm{Tmd}^{124,129}$. Assim, pulsos elétricos aplicados dentro do Tmd eliciam: (1) potenciais de ação ortodrômicos em direção à camada III do CPFm; e (2) potenciais de ação antidrômicos em direção às camadas $\mathrm{V}-\mathrm{VI}$, induzidos pela inevitável estimulação de terminais axonais corticotalâmicos ${ }^{124}$. O recrutamento ortodrômico resulta em respostas unitárias de latência curta que refletem a comunicação rápida talamocortical. Em contraste, o recrutamento antidrômico gera respostas de latência longa, atribuídas à propagação de potenciais de ação ao longo dos ramos colaterais dentro das camadas $\mathrm{V}-\mathrm{VI}^{124}$. Ambas as respostas são bloqueáveis por antagonistas glutamatérgicos ${ }^{125}$, o que confirma que são pós-sinápticas. Para simplicidade, a figura omite: interneurônios GABAérgicos, aferências diretas do Tmd às camadas V-VI (que existem, mas são menos conspícuas), e localização dos terminais présinápticos em relação à altura dos dendritos apicais ${ }^{129}$.

Os estudos de Pirot et al. ${ }^{124-126}$ permitem algumas conclusões gerais. É importante apresentarmos tais conclusões aqui, pois elas serão básicas à interpretação de nossos dados. 
(1) As duas classes de respostas pré-frontais à estimulação do Tmd são pós-sinápticas. (2) As respostas de latência longa são mais sensíveis à manipulação de receptores NMDA e dopaminérgicos, sugerindo que a comunicação colateral entre células pré-frontais vizinhas nas camadas V-VI é mais plástica. (3) De acordo com a neuroanatomia ${ }^{128}$, é provável que a maioria das respostas de latência longa seja emitida por células que se projetam de volta ao Tmd. (4) A propagação antidrômica ao longo dos axônios CPFm-Tmd é, no mínimo, duas vezes mais lenta que a propagação ortodrômica Tmd-CPFm. Supondo-se que a velocidade de propagação ortodrômica CPFm-Tmd seja a mesma da antidrômica, as velocidades diferenciais de propagação entre as vias Tmd-CPFm e CPFm-Tmd corroboram a noção de que as entradas talâmicas ao córtex têm caráter condutor, e que as entradas corticais ao tálamo têm caráter modulador ${ }^{38}$. (5) Tendo em mente que a função das células CPFm-Tmd (camadas V-VI) é mais plástica do que a das células do CPFm (camada III) contatadas pelo Tmd, pode-se supor que a influência modulatória na direção corticotalâmica se responsabilize por flexibilizar a função da alça Tmd-CPFm-Tmd como um todo.

\subsubsection{Plasticidade sináptica}

Em seu livro "The organization of behavior" (1949) ${ }^{131}$, o psicólogo canadense Donald Hebb propôs os mecanismos neuronais que estariam sob a aprendizagem e flexibilidade comportamental. Os mecanismos seriam basicamente dois: (1) padrões de atividade neuronal eliciados por experiência relevante ou repetitiva produziriam correlação ótima, porém instável, entre atividades pré e pós-sinápticas; em seguida, (2) esta correlação induziria eventos metabólicos ou estruturais que, por sua vez, modificariam de maneira estável a eficácia da comunicação entre os neurônios envolvidos. Nos anos 1960-1970, investigações lideradas pelo norueguês Terje Lomo e o britânico Timothy Bliss em coelhos acordados $^{132}$ e anestesiados ${ }^{133}$ forneceram o primeiro suporte eletrofisiológico às ideias de Hebb. A estratégia dos autores foi a de implantar um eletrodo de estimulação dentro de uma via axonal (via perfurante, contendo axônios oriundos do córtex entorrinal ${ }^{134}$ ) e um eletrodo de registro em meio a células inervadas por aquela via (giro denteado ${ }^{134}$ ). A função basal da via neural foi avaliada através de uma sequência de pulsos elétricos isolados, de 
modo que para cada pulso fosse registrada a despolarização da população de células ao redor do eletrodo de registro. Cabe, aqui, um parêntese: este tipo de resposta populacional e extracelular pode ser chamado de potencial pós-sináptico de campo (PPSC). Por resultar da somatória de despolarizações, sejam elas subliminares ou não, o PPSC não deve ser confundido com potenciais de ação unitários. Em seguida, analogamente ao primeiro mecanismo postulado por Hebb, foram testados vários trens de pulsos repetitivos (15-100 $\mathrm{Hz}$ ) após os quais a sequência de pulsos isolados foi retomada. O resultado da manipulação foi que, depois das estimulações em trens, os pulsos isolados passaram a eliciar PPSCs de maior amplitude (despolarizações mais fortes), e o aumento chegou a durar horas (preparação sob anestesia ${ }^{133}$ ) ou dias (sujeitos acordados ${ }^{132}$ ). Considerando-se que a intensidade dos pulsos elétricos foi inalterada ao longo dos experimentos, os autores interpretaram o achado como um aumento duradouro da eficácia sináptica hipocampal, algo que seria análogo ao segundo mecanismo de Hebb. O fenômeno foi denominado potencialização de longa duração (PLD) e desde então vem sendo replicado em todo o encéfalo, principalmente hipocampo e neocórtex ${ }^{135,136}$. Atualmente, sabe-se que as sinapses que sofrem PLD também são capazes de expressar um fenômeno oposto: depressão de longa duração (DLD), isto é, diminuição duradoura da eficácia sináptica, contanto que os trens de pulsos sejam aplicados em frequências da ordem de $1-5 \mathrm{~Hz}^{137,138}$. Juntas, PLD e DLD são referidas como plasticidade sináptica de longa duração e ambas são sensíveis à aprendizagem $^{139}$. Além disto, manipulações farmacológicas ou genéticas que perturbam PLD ou DLD também afetam a aprendizagem, o que torna a plasticidade sináptica um modelo bem aceito de memória no nível celular ${ }^{140}$.

Desde a contribuição pioneira de Lomo e Bliss, houve grande progresso na experimentação in vivo, sob anestesia ou não, e in vitro. Neste último caso, extraem-se fatias coronais, sagitais ou horizontais do encéfalo, para que elas sejam cultivadas sob perfusão de líquido cerebrospinal artificial oxigenado, permitindo-se implantes em estruturas que, na preparação in vivo, seriam de difícil acesso ${ }^{141}$. Experimentos in vitro também são úteis à busca pelos mecanismos moleculares subjacentes à indução e manutenção de PLD e DLD, embora sua maior artificialidade limite extrapolações de cunho fisiológico. De qualquer forma, as vantagens de ambas as técnicas se complementam, e têm mostrado que a interação entre PLD e DLD consiste numa dinâmica envolvendo alterações no mosaico de receptores e reestruturações morfológicas dos terminais sinápticos ${ }^{140}$. 
Um mecanismo prototípico muito estudado e prevalente por todo o encéfalo é o da PLD e DLD dependente de receptores NMDA. Segundo o modelo, o nível de despolarização do terminal pós-sináptico é primariamente regulado pela ligação de glutamato a canais AMPA, cuja abertura permite influxo de cátions monovalentes. Por sua vez, a abertura de canais NMDA depende não só da ligação de glutamato mas também do nível de despolarização da membrana, o que torna a detecção NMDA mais seletiva do que AMPA ${ }^{140}$. Outra diferença é que a abertura de NMDA consiste, na verdade, da desobstrução de seus canais (expulsão de cátions $\mathrm{Mg}^{2+}$ ), o que abre caminho ao influxo de outro cátion bivalente: o $\mathrm{Ca}^{2+}$. O influxo de $\mathrm{Ca}^{2+}$ permitido pelo alívio do bloqueio de $\mathrm{Mg}^{2+}$ faz com que os canais NMDA contribuam adicionalmente à despolarização e, mais importante, ao aumento da concentração citossólica de $\mathrm{Ca}^{2+}$ no terminal pós-sináptico ${ }^{140}$. Dependendo da concentração citossólica de $\mathrm{Ca}^{2+}$, diferentes cascatas de sinalização intracelular dependentes de cálcio podem levar a diferentes regulações sobre o modo com que os receptores AMPA continuarão trabalhando pela despolarização do terminal pós-sináptico. No caso da PLD, tais cascatas podem envolver etapas de fosforilação (por exemplo, da proteína cinase II dependente de cálcio/calmodulina, e proteínas cinases A e C) e no caso da DLD, desfosforilação (por exemplo, a fosfatase calcineurina) ${ }^{140}$. A função de subunidades proteicas dos canais AMPA, e portanto sua condutividade, pode ser modulada diretamente por tais sinalizações intracelulares. Além disto, a própria disponibilidade de receptores AMPA na densidade pós-sináptica pode ser afetada através de incorporação ou remoção baseadas, respectivamente, na exocitose ou endocitose de vesículas que estocam receptores AMPA embebidos em suas membranas. Enfim, mudanças na concentração e/ou condutividade de canais AMPA implicam em mudanças na sensibilidade com que o terminal pós-sináptico responde ao glutamato, o que explicaria a expressão inicial de PLD e DLD ${ }^{140}$.

A regulação do conteúdo da densidade pós-sináptica, por si só, é incapaz de sustentar a PLD e DLD por mais que dezenas de minutos. Assim, para que a expressão eletrofisiológica destes fenômenos permaneça por algumas horas, as cascatas de sinalização que influenciam o conteúdo da densidade pós-sináptica também regulam a síntese proteica dendrítica ${ }^{140}$. Em prazos ainda mais longos, como dias, a síntese de fatores de transcrição codificados por genes de expressão imediata (como Zif-268) influencia o aparato genético nuclear, o que resulta na produção de novos transcritos que também contribuem à síntese proteica dendrítica. Os resultados estruturais consistem na remodelagem de espinhos 
dendríticos, que podem ter sua superfície receptora aumentada, dividida ou diminuída, estabilizando as mudanças na eficácia sináptica ${ }^{140}$. Outros mecanismos de plasticidade de longa duração menos estudados e/ou prevalentes incluem a PLD pré-sináptica dependente de cálcio, que consiste no aumento da neurotransmissão mediado pela mobilização citoesquelética, e a DLD endocanabinóide, induzida por mensageiros retrógrados póssinápticos que inibem a neurotransmissão via receptores pré-sinápticos $\mathrm{CB} 1^{140}$.

PLD e DLD dependentes de receptores NMDA ${ }^{11,26,28,30,142-145}$ também podem ser induzidas no neocórtex aplicando-se estimulações condicionadoras em núcleos talâmicos, bem como na substância branca conectando tálamo e neocórtex. Em particular, o histórico da investigação sobre a plasticidade talamocortical carrega consigo um debate acerca da viabilidade da indução de PLD e DLD nestas vias conforme a idade do indivíduo mamífero. Defendia-se $\mathrm{e}^{11,26,143}$ que a plasticidade talamocortical em áreas corticais primárias seria restrita a um período crítico do desenvolvimento pós-natal (aproximadamente 15 dias de vida, em roedores). Durante tal período, terminais pós-sinápticos corticais contatados por aferências talâmicas seriam pobres em receptores AMPA e, proporcionalmente, ricos em NMDA. Então, a atividade gerada pela experiência sensorial recrutaria preferencialmente receptores NMDA, e os padrões de influxo de $\mathrm{Ca}^{2+}$ mediado por seus canais participariam da regulação dos receptores AMPA quanto à sua exposição e condutividade iônica, o que representaria o refinamento derradeiro da comunicação talamocortical ${ }^{11,26,143}$. De certo modo, isto é coerente com a investigação de Pirot et al. ${ }^{125}$ Afinal, os autores mostraram que, em ratos adultos, a comunicação corticocortical contida no circuito CPFm-Tmd depende de NMDA e AMPA, enquanto a conexão talamocortical Tmd-CPFm depende somente de AMPA. No entanto, recentemente mostrou-se no sistema auditivo in vitro ${ }^{33}$ que a plasticidade persiste na via talamocortical madura, contanto que à solução de cultivo da fatia encefálica seja aplicado um agonista colinérgico (no caso, carbacol). Em ratos anestesiados com uretana, uma série de estudos liderados por Hans Dringenberg também têm induzido PLD e DLD neocortical a partir de núcleos talâmicos sensoriais ${ }^{28-32,145-148}$, inclusive com facilitação colinérgica $^{28,29,31}$. Porém, os autores têm coletado PPSCs sem distinguir com rigor seus componentes talamocorticais ou corticotalâmicos. Em suma, determinados mecanismos de plasticidade talamocortical pós-natal são efêmeros e dependentes de estimulação sensorial. Entretanto, pelo menos os componentes intracorticais dos circuitos talamocorticais mantêm-se plásticos até a vida adulta, especialmente sob condições específicas de 
modulação ascendente. Deve-se reconhecer que as alças talamocorticais variam quanto à sua topografia e ultraestrutura. Além disto, a participação relativa das vias talamocorticais ou corticotalâmicas na plasticidade destas alças ainda não é totalmente elucidada. Portanto, se por um lado a investigação sobre a plasticidade induzida pelo tálamo tem implicações tão variadas e importantes quanto as próprias funções corticais, por outro a interpretação dos PPSCs gerados pela estimulação talâmica tende a ser desafiadora, pelo menos sob os métodos eletrofisiológicos mais comuns atualmente.

A investigação em plasticidade sináptica talamocortical é dominada pela experimentação em vias sensoriais, como o sistema auditivo, visual e somatossensorial. Surpreendentemente, são poucos os estudos que se dedicaram à plasticidade sináptica em sistemas talamocorticais não-sensoriais. Uma dupla de estudos em camundongos acordados $\left(1999^{149}\right.$ e $\left.2002^{150}\right)$ forneceu a primeira contribuição examinando, justamente, o circuito Tmd-CPFm. Trata-se de um outro grupo de pesquisa francês chefiado por René Garcia. Os dois trabalhos (Herry et al. ${ }^{149}$ e Herry e Garcia ${ }^{150}$ ) são interessantes pois não somente avaliaram a plasticidade sináptica Tmd-CPFm pela primeira vez, mas também encontraram associações entre PLD/DLD e aprendizagem Pavloviana. Numa primeira etapa, foram caracterizados os PPSCs pré-frontais evocados por pulsos elétricos aplicados dentro do Tmd. Os autores se depararam com PPSCs de aparência complexa, apresentando um componente de latência curta (pico em $\sim 7 \mathrm{~ms}$ ) e outro de latência longa ( 13 ms), que foram interpretados como correspondentes às duas categorias de respostas previamente reportadas por Pirot et al. ${ }^{124}$ Tendo em vista a dificuldade em identificar claramente o componente de latência curta em todos os sujeitos, Herry et al. ${ }^{149}$ e Herry e Garcia ${ }^{150}$ optaram por medir a plasticidade sináptica de acordo com a amplitude do componente de latência longa, este sim consistente entre sujeitos. A estratégia de medir a amplitude do PPSC sem seletividade quanto ao componente talamocortical e corticotalâmico é similar à usada por Dringenberg para os sistemas sensoriais (por exemplo, referência 29).

Uma vez caracterizados os PPSCs, Herry et al. ${ }^{149}$ aplicaram ao Tmd um trem único de pulsos em baixa frequência (1.200 pulsos a $2 \mathrm{~Hz}$, duração total de $10 \mathrm{~min}$ ) obtendo, em metade dos camundongos, uma DLD que consistiu em diminuição de $20 \%$ da amplitude dos PPSCs pré-frontais. Na outra metade da amostra, observou-se efeito oposto: uma PLD préfrontal representada por um aumento de $\sim 10 \%$ na amplitude dos PPSCs. Esta dualidade imprevista foi discutida apenas superficialmente pelos autores. Num segundo experimento 
do mesmo trabalho, os sujeitos foram submetidos a uma sessão de condicionamento aversivo, na qual tons puros (estímulos condicionados) foram repetidamente apresentados em antecipação a um choque elétrico nas patas (estímulo incondicionado) dentro de uma câmara de condicionamento. Quantificou-se a resposta condicionada de congelamento, isto é, imobilidade associada ao medo condicionado. Nos dois dias seguintes, os sujeitos foram reconduzidos às sessões experimentais, porém as apresentações do tom puro foram desacompanhadas de choques às patas. Assim, a frequência de congelamentos eliciados pelas apresentações não-nocivas do tom puro foi quantificada, de modo que sua diminuição indicaria extinção parcial do medo condicionado. Ora, previamente os animais haviam recebido implante crônico para evocação de PPSCs no CPFm a partir de pulsos ao Tmd. Assim, antes e depois de cada sessão comportamental, os animais foram submetidos a sessões de registro eletrofisiológico. Interessantemente, a amplitude dos PPSCs mostrou um decurso consistente ao longo das sessões comportamentais: no primeiro dia de extinção, os PPSCs fora reduzidos em $\sim 20 \%$. No segundo dia, esta diminuição foi convertida num aumento de $10 \%$ dos PPSCs. Note-se que tais mudanças de amplitude dos PPSCs não foram induzidas por trens de pulsos elétricos, e sim pelo próprio procedimento comportamental.

Como se vê, os resultados eletrofisiológicos de Herry et al. (1999) ${ }^{149}$ foram relativamente inconclusivos e abertos, o que conduziu o grupo de pesquisa a um segundo estudo, mais completo e melhor controlado. Herry e Garcia (2002) ${ }^{150}$ não somente acompanharam a evocação basal de PPSCs ao longo das sessões de extinção do medo, mas também induziram DLD antes delas. Além disto, os autores acompanharam a extinção do congelamento por até sete dias, ao invés de somente dois. Os dados indicaram que a indução de DLD provocou resistência à extinção do congelamento, ou seja, os camundongos que sofreram a DLD pré-frontal tiveram maior dificuldade em perder o medo condicionado, mesmo que os tons puros não estivessem mais precedendo o choque elétrico às patas. Numa segunda etapa do trabalho, os autores repetiram os procedimentos, porém com indução de PLD através de trens de pulsos em altíssima frequência (10 trens de 50 pulsos a $250 \mathrm{~Hz}$ ). A indução de PLD por si só não chegou a afetar a taxa de extinção do medo condicionado. Porém, alguns camundongos tiveram sua PLD incontrolavelmente convertida em DLD, e justamente estes camundongos acabaram regredindo ao nível máximo de medo condicionado, voltando a exibir congelamento com taxas próximas às da sessão de condicionamento. Herry e Garcia ${ }^{150}$ discutiram a extinção do medo condicionado como uma 
reaprendizagem, cuja fase tardia de consolidação exigiria a participação ativa do CPFm. A sequência depressão-potencialização sináptica observada no CPFm ao longo de até sete dias ajuda a sustentar esta noção. Por sua vez, a manutenção da depressão sináptica pré-frontal ao longo de dias, com ou sem indução de DLD, promoveu resistência a tal reaprendizagem, o que pode ser interpretado como prejuízo à flexibilidade comportamental e, extrapolando-se à condição humana, dificuldade de vencer um medo previamente adquirido ${ }^{150}$. Estudos de imageamento já haviam mostrado decréscimo do fluxo sanguíneo no CPF em pacientes com estresse pós-traumático enquanto recebiam exposição de material aversivo ${ }^{151,152}$. Opostamente, aumentos de fluxo sanguíneo pré-frontal já haviam sido associados à extinção de sintomas do estresse pós-traumático durante terapias cognitivas ${ }^{153}$. Assim, Herry e Garcia $^{150}$ propuseram que a plasticidade pré-frontal em roedores, mesmo que induzida a partir de estimulação talâmica, gera implicações para processos básicos de aprendizagem e, por conseguinte, eventuais estratégias neuropsiquiátricas contra o medo persistente.

\subsubsection{Estudos em humanos}

A reciprocidade Tmd-CPF também tem sido, direta ou indiretamente, objeto de estudo em humanos. Em sujeitos saudáveis sob ressonância magnética funcional, testes neuropsicológicos como jogos de cartas (Wisconsin Card Sorting) e tarefas verbais induziram aumento de sinal em ambas as regiões ${ }^{154-159}$. Particularmente, o CPF foi implicado na retenção de respostas ${ }^{154}$, o Tmd na mudança de estratégias conforme demandas da tarefa $^{155}$, e ambos na antecipação oculomotora a estímulos visuais ${ }^{156}$. Testes neuropsicológicos em pacientes que sofreram acidente vascular talâmico abarcando o Tmd também mostraram prejuízo em funções executivas reconhecidamente dependentes do $\mathrm{CPF}^{160}$. Outro corpo de evidências proeminente é representado pela estereologia postmortem. É bem sabido que o Tmd de pacientes diagnosticados com esquizofrenia têm perda celular e volumétrica ${ }^{161,162}$, que pode ser acompanhada por respostas inflamatórias no Tmd (microgliose) $)^{163}$ e regressão de terminais talâmicos no $\operatorname{CPF}^{164}$. Tecidos de pacientes postmortem não mostram uma patologia tão clara no $\mathrm{CPF}^{165}$. Isto indica que a perda das entradas talâmicas ao CPF, mas não a perda celular do CPF, pode contribuir à hipofunção 
pré-frontal subjacente às esquizofrenias ${ }^{166}$. Em pacientes vivos, a perda volumétrica e metabólica do tálamo (inclusive Tmd) nas esquizofrenias foi reforçada por estudos de imageamento e comparação morfométrica de voxel a voxel ${ }^{167,168}$. Além disto, estudos de imageamento por tractografia, que é sensível à difusão aquosa ao longo de feixes axonais, não apenas confirmaram a conectividade entre CPF e Tmd em humanos ${ }^{169}$, mas também sugeriram distribuição mais esparsa das fibras entre o CPF e o Tmd em pacientes com esquizofrenias ${ }^{170,171}$. Ainda sob ressonância magnética, o teste neuropsiquiátrico de inibição por pré-pulso - cuja medida é o reflexo palpebral eliciado por: (1) pulso sonoro forte; ou (2) pulso sonoro forte precedido por um pré-pulso fraco - indica utilização do circuito CPFestriado-Tmd em controles saudáveis e sub-utilização deste circuito nas esquizofrenias ${ }^{172}$.

Afora o interesse em torno do circuito Tmd-CPF nas esquizofrenias, estudos em humanos também têm acessado o envolvimento deste circuito na depressão maior e transtornos de humor ${ }^{173,174}$, geração dos fusos do sono no $\mathrm{CPF}^{175}$, e recrutamento do Tmd a partir da estimulação magnética transcraniana do $\mathrm{CPF}^{176}$. Ainda assim, a quantidade de trabalhos não relacionados às esquizofrenias é bem menor. Em particular, faltam estudos de neuroimagem e estereologia post-mortem diretamente interessados na participação deste circuito nas epilepsias. A recente contribuição de Edward Bertram e colaboradores após experimentos em ratos ${ }^{177-184}$ tem sugerido que o Tmd é crítico à amplificação de crises límbicas, indicando a necessidade de estudos clínicos direcionados a esta questão.

\subsection{Sistema colinérgico encefálico}

\subsubsection{Acetilcolina e fármacos colinérgicos}

A acetilcolina foi o primeiro neurotransmissor a ser identificado (início do século XX), e sua descoberta foi crucial para a atual noção de sinapses químicas. Ela foi pioneiramente isolada pelo farmacologista britânico Henry Dale (anos 1910-1920), a partir de alcaloides produzidos por um fungo (Claviceps purpurea, ou esporão) que ataca lavouras de centeio ${ }^{185}$. O interesse pelo estudo bioquímico do fungo provinha do fato de que sua contaminação aos 
alimentos derivados de centeio poderia causar ergotismo, que inclui sintomas como alucinações e vasoconstrição ${ }^{185}$. Na mesma época, o colega alemão de Henry Dale, Otto Löewi, realizou um experimento em que dois corações de rãs in vitro, um conectado ao nervo vago e outro não, foram perfundidos com um mesmo líquido fisiológico ${ }^{185}$. A estimulação elétrica do nervo vago reduziu a frequência de batimentos em ambos os corações, o que indicou a existência de um mediador químico liberado pelo nervo vago. No progresso da colaboração, Dale e Löewi demonstraram que o mediador químico era justamente a acetilcolina, o que rendeu a ambos um prêmio Nobel compartilhado $(1936)^{185}$.

Desde então, o estudo da acetilcolina como neurotransmissor aumentou o conhecimento sobre junções neuromusculares e sinapses dos gânglios viscerais ${ }^{185}$. Diferentemente, a pesquisa sobre a neurotransmissão colinérgica no sistema nervoso central começou a atrair interesse mais tarde, principalmente a partir dos anos 1970, quando começou a ficar claro o envolvimento do sistema colinérgico no desempenho cognitivo $^{186,187}$. Para a investigação das funções colinérgicas superiores, a aplicação sistêmica ou local de agentes farmacológicos foi, e ainda é, muito usada ${ }^{188}$. Tais agentes podem prolongar a disponibilidade de acetilcolina na fenda sináptica ao inibirem sua enzima hidrolítica, a acetilcolinesterase. Trata-se dos inibidores da acetilcolinesterase, que incluem paliativos aos estágios iniciais da doença de Alzheimer, como donepezil e galantamina ${ }^{189}$. Outras drogas atuam sobre os receptores colinérgicos centrais, bloqueando-os ou ativandoos com vários graus de seletividade quanto aos subtipos de receptores. Antagonistas de receptores colinérgicos muscarínicos incluem a escopolamina, cujo excesso pode causar alucinações e prejuízos cognitivos temporários ${ }^{190}$. Antagonistas de receptores nicotínicos incluem a mecamilamina, cujo efeito central pode ajudar contra a dependência ao tabaco ${ }^{191}$.

Também há um repertório de agonistas colinérgicos usados para fins clínicos, recreativos e de pesquisa. A presente Tese dá foco a dois deles: o agonista muscarínico nãoseletivo pilocarpina (PILO) e o agonista nicotínico não-seletivo nicotina (NIC). PILO é uma substância alcaloide originalmente extraída das folhas de um arbusto amazônico, Pilocarpus microphyllus, popularmente chamado de jaborandi ${ }^{192,193}$. A palavra tupi-guarani equivalente a jaborandi significa "planta que faz babar", o que é condizente com o aumento de salivação causado pela ingestão das folhas da planta ${ }^{192,193}$. PILO é comercializada principalmente na forma do sal cloridrato de pilocarpina e tem dois fins clínicos bem conhecidos: o combate ao glaucoma ${ }^{194}$ e à xerostomia (boca seca) ${ }^{195}$. Em roedores, quando aplicada por via sistêmica 
ou intra-hipocampal em doses altas, PILO induz um estado persistente de crise motora inconsciente (Status Epilepticus) que pode ser interrompido pela injeção sistêmica de anticonvulsivantes $^{196-198}$. Ratos que sofreram Status Epilepticus podem desenvolver crises recorrentes espontâneas semanas após a aplicação de PILO. Tais crises crônicas são associadas à esclerose hipocampal, que é uma referência patológica bem conhecida da epilepsia do lobo temporal mesial humano. Isto torna o Status Epilepticus induzido por PILO um modelo bem aceito deste tipo de epilepsia focal, que é o mais prevalente ${ }^{196-198}$.

NIC é outra substância alcaloide presente nas folhas de plantas originalmente sulamericanas: Nicotiana sp., ou tabaco. Seu uso recreativo por via inalatória (fumo), que já era habitual dentre índios nativos americanos, foi descoberto pelos primeiros colonizadores da América e disseminado ao longo da península ibérica no século $\mathrm{XVI}^{199}$. À época, o embaixador francês em Lisboa Jean Nicot (daí o nome nicotina) aprovou o fumo como suposto remédio contra a dor de cabeça e divulgou-o ao meio político parisiense, a partir do qual o uso de tabaco se popularizou pelo resto da Europa ${ }^{199}$. O emprego de NIC com fins de pesquisa é mais antigo que o da PILO. A pesquisa sobre NIC remonta ao trabalho do fisiologista francês Claude Bernard (século XIX), que descreveu seus efeitos estimulantes sobre músculos esqueléticos ${ }^{200}$. No caso do sistema nervoso central, o escopo da pesquisa envolvendo NIC é mais amplo que o da PILO. NIC em várias formas, como o líquido (-)nicotina e o sal hidrogeno-tartarato de (-)-nicotina, é usada em estudos abrangendo os efeitos cognitivos do abuso e abstinência ${ }^{201,202}$, modulação da plasticidade sináptica hipocampal ${ }^{203}$, vulnerabilidade do adolescente à dependência química ${ }^{204}$, interação desta dependência com alcoolismo $o^{205}$ e transtornos neuropsiquiátricos ${ }^{206,207}$, dentre outros temas.

\subsubsection{Receptores muscarínicos}

O nome dos receptores muscarínicos faz referência ao seu agonista não-seletivo muscarina, inicialmente extraído de um cogumelo de clima temperado (Amanita muscaria), mas também presente em outros fungos ${ }^{208}$. Existem cinco tipos identificados de receptores muscarínicos $\left(\mathrm{M}_{1}-\mathrm{M}_{5}\right)$ e todos são metabotrópicos, ou seja, suas ações intracelulares são mediadas por proteínas $\mathrm{G}$ (inativadas por ligação a guanosina difosfato, e ativadas por 
ligação a guanosina trifosfato) que atuam na face intracelular da membrana plasmática ${ }^{209,210}$. Os tipos de proteínas $G$, no entanto, variam conforme o tipo de receptor muscarínico, o que motiva a divisão destes receptores em dois grupos: $M_{1}$ acoplado a proteínas $G_{q / 11}\left(M_{1}, M_{3}\right.$ e $\left.M_{5}\right)$ e $M_{2}$ acoplado a proteínas $G_{i / o}\left(M_{2} \text { e } M_{4}\right)^{210,211}$.

A ativação dos receptores do grupo- $\mathrm{M}_{1}$ por um ligante extracelular desacopla sua proteína $\mathrm{G}_{\mathrm{q} / 11}$ intracelular, que por sua vez estimula a fosfolipase $C$. Atrelada à membrana plasmática, a fosfolipase $\mathrm{C}$ cliva fosfolipídios em inositol trifosfato (que libera estoques de $\mathrm{Ca}^{2+}$ do retículo endoplasmático por meio da interação com canais de cálcio) e diacilglicerol (que junto com $\mathrm{Ca}^{2+}$ ativa proteínas cinases $\mathrm{C}$ (209-211. $^{\mathrm{O}}$ envolvimento indireto do grupo- $\mathrm{M}_{1}$ na liberação intracelular de $\mathrm{Ca}^{2+}$ e ativação das cinases $\mathrm{C}$ indica que estes receptores interagem com muitas vias de sinalização, o que torna seus efeitos citossólicos complexos ${ }^{210}$. Não obstante, o grupo- $M_{1}$ também induz efeitos mais específicos sobre o potencial eletroquímico da membrana plasmática, que são expressados como redução da condutância de $\mathrm{K}^{+} \mathrm{e}$, por conseguinte, despolarização ${ }^{212}$. Em detalhes, canais de potássio $\mathrm{K}_{\text {ir }}$ ("ir" significando inward rectifier) normalmente permanecem abertos, auxiliando o trânsito de $\mathrm{K}^{+}$ importante à manutenção do potencial de repouso. A abertura dos canais $K_{i r}$ é sustentada por sua interação com um fosfolipídio presente na membrana plasmática: o fosfatidilinositol-4,5-bifosfato ${ }^{213}$. Ora, a fosfolipase $C$ reduz a proporção deste fosfolipídio na composição da membrana plasmática. A consequência disto é a diminuição da proporção de canais $\mathrm{K}_{\text {ir }}$ abertos e, finalmente, enfraquecimento do potencial de repouso ${ }^{212}$.

Por sua vez, os receptores do grupo- $\mathrm{M}_{2}$ possuem efeitos, em geral, opostos aos do $M_{1}$. O desacoplamento entre o receptor do grupo- $M_{2}$ e proteínas $G_{i / o}$ inibe a adenilato ciclase, cuja ação seria a de catalisar a quebra da adenosina trifosfato em adenosina monofosfato cíclica ${ }^{209-211}$. O fato de a adenilato ciclase ser inibida pela proteína $G_{i / o}$ implica em redução da presença de adenosina monofosfato cíclica no citossol e, consequentemente, inibição da atividade de proteínas cinases $A^{209-211}$. A estimulação do grupo- $M_{2}$ também gera efeitos eletroquímicos imediatos, e tais efeitos também são mediados por canais de $\mathrm{K}^{+}$. Neste caso, porém, determinados canais de $\mathrm{K}^{+}$que permanecem normalmente fechados têm a probabilidade de abertura aumentada pela sua interação direta com as proteínas $G_{i / 0}$, que contribui para a hiperpolarização e, consequentemente, inibição ${ }^{211,214}$.

Um levantamento imuno-histoquímico sobre a localização dos receptores muscarínicos no rato ${ }^{215}$ indicou que eles estão espalhados por todo o encéfalo. Porém, 
diferenciando-se os subtipos $M_{1}, M_{2}, M_{3}$ e $M_{4}$, notou-se que algumas regiões são ricas em um subtipo e pobres no outro. As regiões com distribuição diferencial mais evidente são o diencéfalo (rico em $M_{2}$ e $M_{3}$, mas pobre em $M_{1}$ e $M_{4}$ ), hipocampo (rico em $M_{1}, M_{2}$ e $M_{3}$ e pobre em $\mathrm{M}_{4}$ ) e tronco encefálico (rico em $\mathrm{M}_{2}$ e pobre nos demais). Neocórtex, amígdala e estriado apresentam todos os subtipos em proporções mais homogêneas ${ }^{215}$. Os receptores do grupo- $\mathrm{M}_{2}$ são preferencialmente pré-sinápticos, pois se localizam majoritariamente em terminais axonais ${ }^{210}$. Alguns destes terminais são colinérgicos, o que indica que receptores do grupo- $\mathrm{M}_{2}$ também atuam como autoceptores ${ }^{216}$. Opostamente, o grupo- $\mathrm{M}_{1}$ é preferencialmente pós-sináptico, ocorrendo no pericário, eixos dendríticos proximais e ramos dendríticos distais ${ }^{210}$. Ressalte-se, porém, que todas as divisões subcelulares expressam receptores muscarínicos de todos os tipos, independentemente da região encefálica ${ }^{210}$, o que os impede de serem classificados absolutamente como pré ou póssinápticos. Também há receptores muscarínicos em interneurônios GABAérgicos do córtex cerebral e neurônios GABAérgicos do $\mathrm{TRt}^{210}$. Portanto, embora possamos considerar a ação geral do grupo- $\mathrm{M}_{1}$ como excitatória e do grupo- $\mathrm{M}_{2}$ como inibitória, cada região encefálica reage de maneiras específicas à presença de acetilcolina, dependendo da proporção dos subtipos de receptores muscarínicos e sua localização subcelular ${ }^{215}$.

Dada a similaridade entre receptores muscarínicos quanto à estrutura proteica, a maioria dos agonistas e antagonistas muscarínicos é não-seletiva ${ }^{217}$. Este também é o caso da PILO, que estimula receptores dos grupos $-\mathrm{M}_{1}$ e $\mathrm{M}_{2}{ }^{218-222}$. Porém, PILO tem mais afinidade aos receptores do grupo- $M_{1}$, especialmente o próprio $M_{1}$, que é o mais abundante do córtex cerebral e o principal responsável pelas crises motoras induzidas por PILO ${ }^{219,221}$.

\subsubsection{Receptores nicotínicos}

$\mathrm{O}$ nome dos receptores nicotínicos provém de sua sensibilidade à $\mathrm{NIC}^{200}$. Em contraste com os receptores muscarínicos, os nicotínicos são canais iônicos ativados por ligante. Os canais são preenchíveis por solução aquosa e delimitados por uma estrutura pentamérica construída por cinco subunidades proteicas ${ }^{223}$. Até o momento, 17 subunidades foram identificadas em vertebrados: $\alpha$ (1-10), $\beta$ (1-4), $\gamma, \delta, \varepsilon$. Diferentes combinações de 
subunidades na composição do canal pentamérico multiplicam os receptores nicotínicos numa diversidade de tipos maior que a de receptores muscarínicos ${ }^{224}$. Nos neurônios, as subunidades são apenas $\alpha(2-6)$ e $\beta(2-4)$, e as combinações mais comuns do encéfalo mamífero são a heteromérica $\alpha 4 \beta 2$ (formada por duas subunidades $\alpha 4$ e três $\beta 2$, ou três $\alpha 4$ e duas $\beta 2$ ), e a homomérica $\alpha 7$, formada por cinco subunidades $\alpha 7^{200}$. Tendo em vista que $\alpha 4 \beta 2$ e $\alpha 7$ são os receptores nicotínicos neurais mais prevalentes e, também, os mais sensíveis à $\mathrm{NIC}^{223-225}$, trataremos somente deles daqui em diante.

A ação nicotínica é mais rápida do que a muscarínica e contribui diretamente à despolarização, pois a abertura de seus canais permite o influxo de cátions $\mathrm{Na}^{+}$e $\mathrm{Ca}^{2+}$ a favor do gradiente de concentração ${ }^{223}$. A permeabilidade alta ao $\mathrm{Ca}^{2+}$ é típica dos receptores nicotínicos neurais, e a razão da permeabilidade entre $\mathrm{Na}^{+}$e $\mathrm{Ca}^{2+}$ varia conforme o tipo de receptor. Em receptores heteroméricos como o $\alpha 4 \beta 2$ o influxo de $\mathrm{Ca}^{2+}$ é aproximadamente duas vezes maior do que o de $\mathrm{Na}^{+}$, e em homoméricos como $\alpha 7$ a permeabilidade ao $\mathrm{Ca}^{2+}$ chega a ser dez vezes maior ${ }^{226}$. Portanto, a ação nicotínica não se limita à despolarização rápida, pois ela também participa da regulação dos níveis citossólicos de cálcio ${ }^{226}$.

Um trabalho de marcação autorradiográfica ${ }^{227}$ levantou a localização dos receptores nicotínicos neurais do rato sem diferenciar subtipos. Os receptores nicotínicos são espalhados por todo o encéfalo, porém a maior concentração reside no tálamo (mas não hipotálamo), colículo superior, ATV e núcleo interpeduncular. A presença de receptores nicotínicos no neocórtex, estriado, amígdala e hipocampo é moderada, sendo maior no córtex retrosplenial e CPFm ${ }^{227,228}$. A principal localização subcelular dos receptores nicotínicos é o terminal pré-sináptico, de onde a ação nicotínica regula a liberação de dopamina, noradrenalina, serotonina, glutamato, GABA e a própria acetilcolina ${ }^{223}$. O influxo de $\mathrm{Ca}^{2+}$ através dos canais nicotínicos contribui à despolarização do terminal, estimulando canais de cálcio dependentes de voltagem cuja abertura permite ainda mais influxo de $\mathrm{Ca}^{2+}$. O efeito disto é o aumento da mobilização citoesquelética subjacente à ciclagem de vesículas e liberação dos conteúdos neurotransmissores ${ }^{223}$. Em terminais glutamatérgicos, este sinal de cálcio também influencia a atividade de proteínas cinases e fosfatases, o que pode regular adicionalmente a atividade pré-sináptica ${ }^{223}$. Em menor quantidade, também existem receptores nicotínicos extra-sinápticos em dendritos, pericários e segmentos axonais pré-terminais. Eles respondem à acetilcolina não-sináptica (transmissão por volume na matriz extracelular) regulando o potencial de repouso ou, quando estrategicamente 
localizados em bifurcações axonais, alterando a maneira com que os potenciais de ação se propagam neste ou naquele ramo ${ }^{200,223}$. Interneurônios GABAérgicos corticais e talâmicos (quando presentes) também apresentam receptores nicotínicos ${ }^{200}$. Em suma, enquanto a ação muscarínica regula de maneira lenta a liberação pré-sináptica e a recepção póssináptica, a principal ação nicotínica afeta rápida e diretamente o sinal pré-sináptico. Assim, as funções das duas famílias de receptores são coerentes com o caráter modulador da transmissão colinérgica, tanto em circuitos locais quanto em redes amplas.

\subsubsection{Projeções ascendentes e fisiologia}

O sistema colinérgico ascendente se origina de duas regiões. Uma delas reside entre a ponte e o mesencéfalo, e corresponde aos núcleos PPT e LDT, que enviam projeções principalmente ao tálamo e núcleos aminérgicos vizinhos ${ }^{54,60,62,119}$. A outra está contida no prosencéfalo basal, que inerva amplamente o telencéfalo, exceto o estriado ${ }^{54,60,119,223}$. 0 prosencéfalo basal inclui: (1) septo e parte da banda diagonal, que se projetam ao hipocampo; e (2) nucleus basalis magnocellularis (NBM, ou núcleo de Meynert em humanos), que se projeta ao neocórtex. Em ratos, grupos celulares vizinhos ao NBM (por exemplo, substantia innominata) também contribuem com projeções colinérgicas ao neocórtex ${ }^{54,60,119}$. A parte rostral do PPT/LDT envia projeções colaterais ao prosencéfalo basal, indicando que as projeções colinérgicas ao telencéfalo também são sujeitas ao controle do tronco encefálico ${ }^{59}$. Por fim, um grupo de células colinérgicas estriatais inerva o tubérculo olfatório ${ }^{60,229}$ e algumas projeções do prosencéfalo basal se dirigem ao $\mathrm{TRt}^{54}$. Basicamente, os terminais colinérgicos são varicosidades, ou seja, sequências de dilatações ao longo de um mesmo ramo axonal, que vão liberando acetilcolina à medida que os potenciais de ação se propagam ${ }^{62,223}$. Varicosidades colinérgicas podem, ou não, fazer contatos com terminais pós-sinápticos. Isto é, parte das varicosidades libera acetilcolina difusamente na matriz extracelular ${ }^{62,223}$. No tálamo, a proporção entre varicosidades sinápticas e não-sinápticas varia conforme o núcleo ${ }^{62}$. No córtex, a visão tradicional é a de que as varicosidades colinérgicas não-sinápticas predominam, embora estudos de microscopia eletrônica sugiram uma maior proporção de varicosidades sinápticas ${ }^{223}$. 
Atualmente, o debate morfológico quanto à proporção entre varicosidades sinápticas e não-sinápticas corticais é concomitante a um outro debate, de interesse fisiológico. Neste debate, discute-se a importância relativa entre a transmissão colinérgica sináptica e a nãosináptica, sendo a última conhecida como transmissão por volume. Revisões produzidas pelos estadunidenses Michael Hasselmo ${ }^{188,230}$ e Martin Sarter ${ }^{231,232}$ comentam sobre os dois métodos mais usados na medida de concentração extracelular de acetilcolina. No mais tradicional deles, emprega-se uma sonda de microdiálise intracortical em animais in vivo (por exemplo, CPFm de ratos) comportando-se durante testes de atenção. Nos testes, ratos recebem estímulos visuais antecipando-se repetidamente à entrega de comida ou água. Uma vez condicionados, os animais respondem aos estímulos desengajando-se de comportamentos aleatórios e orientando-se ao comedouro/bebedouro. Quantifica-se, assim, os estímulos que eliciaram a resposta de orientação (estímulos atendidos) e aqueles que não eliciaram a resposta (estímulos perdidos). Uma sequência de estímulos atendidos pode induzir aumentos de até $40 \%$ da concentração extracelular de acetilcolina, que podem se manter por minutos enquanto durar a tarefa ${ }^{188,232}$. Trata-se, portanto, de uma liberação tônica de acetilcolina, cuja cinética lenta é coerente com a noção de transmissão por volume $^{188,232}$. No entanto, o uso recente de um outro tipo de sonda cortical tem mostrado um padrão bem diferente de transmissão colinérgica. Determinados microeletrodos preenchidos com acetilcolinesterase detectam um subproduto da hidrólise de acetilcolina (colina) com maior resolução temporal. Sob esta sondagem, os estímulos atendidos (mas não os estímulos perdidos) são associados a liberações fásicas de acetilcolina, que duram apenas alguns segundos ${ }^{188,232}$. Hasselmo, Sarter e colaboradores $^{188,232}$ propõem que a existência de sinais colinérgicos fásicos confronta a opinião tradicional de que a transmissão colinérgica seria exclusivamente difusa e lenta. Mesmo assim, os autores admitem que a descoberta dos sinais fásicos ainda não elimina a plausibilidade dos sinais tônicos. Portanto, a transmissão colinérgica subjacente à atenção e cognição (particularmente no CPF) ainda não teve seu perfil temporal totalmente elucidado, embora o envolvimento do prosencéfalo basal na promoção do alerta cortical já esteja bem assimilado pela literatura ${ }^{233}$.

Boa parte do interesse sobre o prosencéfalo basal como promotor cognitivo é motivado por seu envolvimento na doença de Alzheimer, caracterizada pela aglutinação de peptídeos $\beta$-amiloides (placas senis) a partir da clivagem de proteínas transmembrana precursoras de amiloides, presentes em sinapses corticais ${ }^{234}$. Possivelmente, uma das causas 
da produção de $\beta$-amiloides no córtex seria a retração das aferências colinérgicas do prosencéfalo basal $^{234}$. Na doença de Alzheimer os terminais pré-sinápticos colinérgicos no córtex são pobres em tirosina-cinases, que têm afinidade a neurotrofinas retrogradamente produzidas pelo tecido-alvo cortical ${ }^{235}$. Considerando-se que a sinalização neurotrófica é importante para a sobrevivência axonal, o déficit desta sinalização provocaria regressão dos axônios do prosencéfalo basal e consequente perda de transmissão colinérgica ${ }^{235}$. Isto implicaria na menor ativação de receptores muscarínicos (grupo- $\mathrm{M}_{1}$ ) e nicotínicos (homoméricos $\alpha 7$ ) que, em condições normais, impedem indiretamente a clivagem de $\beta$ amiloides $^{234}$. A perda da inervação colinérgica também é encontrada na demência sob doença de Parkinson, patologicamente marcada por agregados peptídicos intracelulares (corpos de Lewy) presentes não somente no córtex, mas também no NBM ${ }^{236}$. A demência sob doença de Parkinson gera sintomas cognitivos similares aos da doença de Alzheimer, e ambas as doenças podem ocorrer em comorbidade ${ }^{236}$. Transtornos cognitivos dependentes do sistema colinérgico também são comuns em pacientes diagnosticados com esquizofrenia. Neste caso, porém, não há uma referência patológica implicando o prosencéfalo basal. Ao invés disso, as disfunções colinérgicas da esquizofrenia estão restritas ao nível dos receptores, e elas interagem de maneira complexa com outros sistemas de neurotransmissão ${ }^{237,238}$. A marcação por ligantes radioativos indica menor concentração de receptores muscarínicos e nicotínicos ao longo do telencéfalo e tálamo de pacientes com esquizofrenia, e a estimulação nicotínica pelo fumo de cigarro (hábito proporcionalmente mais prevalente em pacientes com esquizofrenia do que na população em geral ${ }^{206}$ ) melhora temporariamente déficits cognitivos ${ }^{237,238}$. Além disto, o tratamento de sintomas positivos (por exemplo, alucinações) com antipsicóticos de primeira e segunda geração pode colateralmente desregular a transmissão colinérgica no córtex, prejudicando adicionalmente o desempenho cognitivo ${ }^{238,239}$. Sugere-se que este desequilíbrio colinérgico seja devido à ação dos antipsicóticos sobre receptores dopaminérgicos e neurotrofinas em células colinérgicas, através de mecanismos não totalmente compreendidos ${ }^{238,239}$. De qualquer forma, os déficits cognitivos sob esquizofrenia e doenças de Alzheimer e Parkinson são parcialmente devidos a disfunções da transmissão colinérgica cortical, implicando direta ou indiretamente as terminações provenientes do prosencéfalo basal.

Ressalte-se, porém, que o prosencéfalo basal é a parte rostral do sistema colinérgico, e sua atividade é dependente do controle que ascende do tronco encefálico. Ou seja, os 
episódios de alerta regulados pelo prosencéfalo basal fazem parte do contexto mais amplo do ciclo sono-vigília, que embora seja executado pelas alças talamocorticais, é governado pela interface entre PPT/LDT e núcleos aminérgicos (locus coeruleus e núcleos da rafe) do tronco encefálico ${ }^{61,240,241}$. Em mais detalhes, a porção rostral dos núcleos PPT/LDT tem atividade tônica não só durante o sono paradoxal mas também na vigília ${ }^{240}$. Significativamente, este conjunto de células fornece projeções ascendentes que se bifurcam em dois caminhos: um direcionado ao tálamo e outro ao prosencéfalo basal ${ }^{59}$. Por sua vez, a porção caudal do complexo PPT/LDT só se despolariza durante o sono paradoxal. Esta porção caudal também envia projeções ao tálamo, mas ao invés de enviar aferências ao prosencéfalo basal, mantém retroalimentação negativa com a rafe e o locus coeruleus ${ }^{240}$. No modelo sumarizado por McCarley (2007) $)^{240}$, a rafe e o locus coeruleus estão tonicamente ativos na vigília, contribuindo para a modulação do encéfalo consciente e, ao mesmo tempo, inibindo o complexo PPT/LDT caudal, mas não o rostral. Em contraste, durante o sono de ondas lentas a atividade da rafe e do locus coeruleus é reduzida, permitindo que o PPT/LDT caudal sofra uma escalada gradual de sua atividade tônica, autossustentada por retroalimentação positiva interna. Assim, o PPT/LDT caudal atinge um pico de liberação de acetilcolina no tálamo, cuja células talamocorticais se despolarizam e passam a manifestar oscilações beta-gama, estabelecendo o sono paradoxal ${ }^{61,241-243}$. Enquanto isto, a atividade do PPT/LDT passa a excitar a rafe e o locus coeruleus, que por sua vez reagem retroalimentando negativamente o PPT/LDT, interrompendo o sono paradoxal e reiniciando o processo ${ }^{240,244}$. A alternância entre atividade tônica dos núcleos PPT/LDT e retroalimentação negativa da rafe e locus coeruleus explicaria o revezamento entre o sono de ondas lentas e o sono paradoxal, referido como arquitetura do sono ${ }^{240}$. Esta, por sua vez, estaria sob a regulação temporalmente mais ampla dos ritmos hormonais circadianos ${ }^{65}$ com participação da neuromodulação peptidérgica oriunda do hipotálamo ${ }^{245}$, mas este tema não será abordado aqui. Note-se que a interface colinérgica e aminérgica entre PPT/LDT, núcleos da rafe e locus coeruleus inclui conexões glutamatérgicas e GABAérgicas ${ }^{246,247}$, cuja complexidade também não detalharemos. 


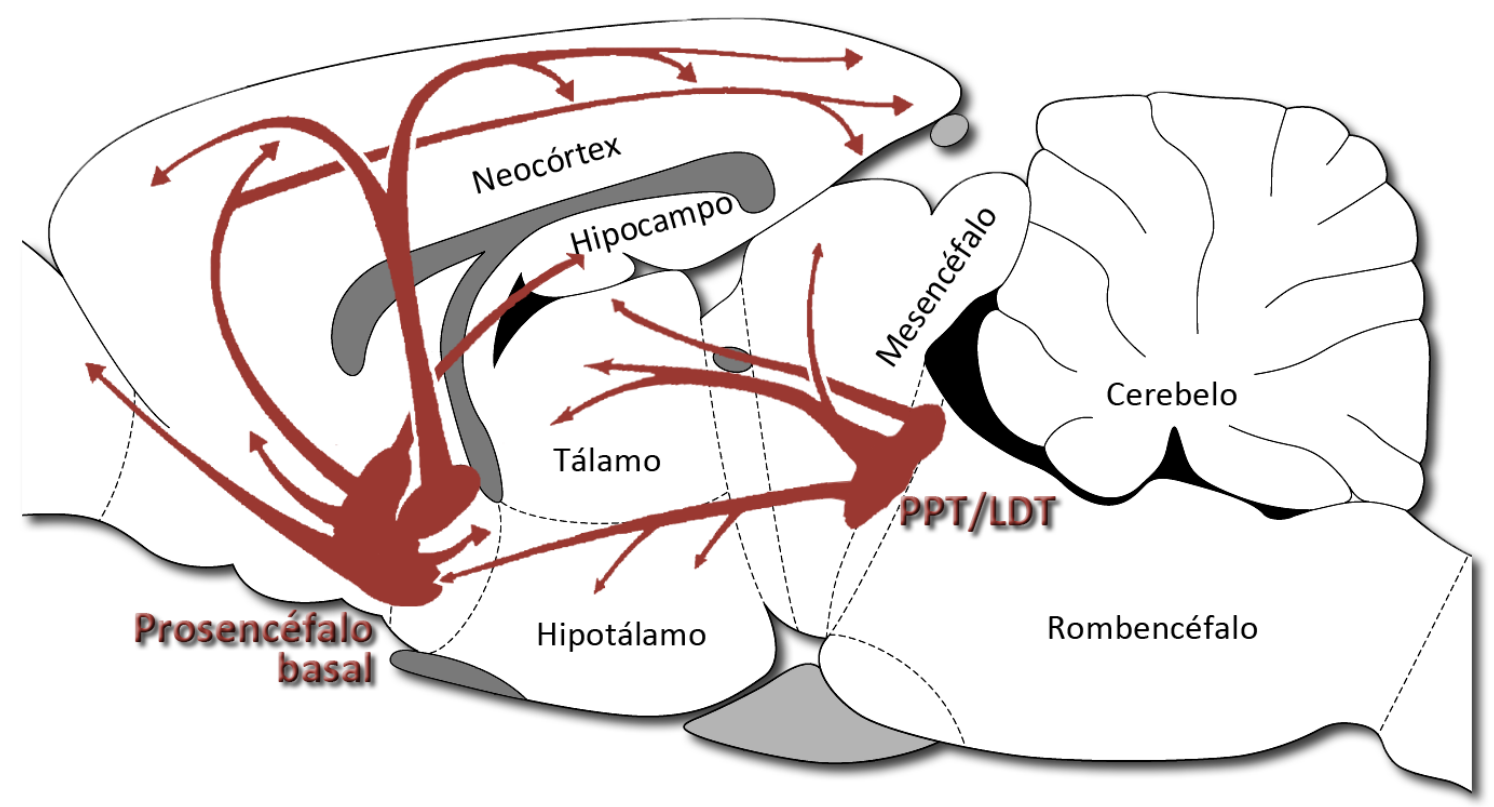

Figura 3. Principais vias ascendentes do sistema colinérgico de roedores. A divisão caudal do sistema colinérgico é representada pelos núcleos ponto-mesencefálicos PPT e LDT, cujas projeções se destinam principalmente ao tálamo. A inervação colinérgica no tálamo é responsável pelo estado oscilatório do sono paradoxal. O controle desta influência sobre o tálamo depende de uma interface entre PPT/LDT, núcleos da rafe e locus coeruleus (vide texto). A porção rostral do sistema colinérgico é representada pelo conjunto de núcleos contido no prosencéfalo basal. O prosencéfalo basal, que também recebe projeções dos núcleos PPT/LDT, é composto principalmente pelo NBM, parte da banda diagonal, substantia innominata e septo. As projeções do prosencéfalo basal alcançam basicamente o córtex, sendo as projeções do septo destinadas especificamente ao hipocampo. Diferentemente dos núcleos PPT/LDT, o prosencéfalo basal é mais relacionado à modulação colinérgica durante a vigília, favorecendo o alerta e a atenção. O plano sagital foi obtido da referência 119, e a topografia das projeções (setas e núcleos vermelhos) provém da referência 240.

\subsubsection{O sistema colinérgico sob anestesia por uretana}

Experimentos de plasticidade sináptica in vivo podem ser feitos em animais acordados (com implante crônico de eletrodos) ${ }^{149,150}$ ou anestesiados ${ }^{29,30}$. A preparação em animais acordados permite avaliação comportamental antes, durante, ou depois das sessões de registro eletrofisiológico. Além disto, as inferências podem ser mais facilmente extrapoladas aos mecanismos naturais de plasticidade, inclusive em modelos experimentais de doenças neuropsiquiátricas. No entanto, a construção e manutenção dos implantes crônicos é trabalhosa, a proteção contra ruídos elétricos pode ser difícil, e o risco de deslocamento acidental dos eletrodos é alto, sem falar de questões bioéticas. A preparação em animais anestesiados reduz tais dificuldades, possibilitando experimentos mais 
uniformes e amostragens mais numerosas, além de ser conveniente à precisão dos implantes e padronização de coordenadas estereotáxicas novas.

Um anestésico muito usado em experimentos in vivo é a uretana ${ }^{248}$, cuja aplicação intraperitonial $^{249}$ ou intravenosa ${ }^{250}$ induz anestesia irreversível. Um conhecimento importante aos estudos in vivo, inclusive o presente estudo, é o de que a anestesia por uretana afeta os sistemas neurotransmissores, cardiovasculares e respiratórios de maneira equilibrada e modesta ${ }^{248,251}$. Hara e Harris ${ }^{251}$ detalharam especificamente os efeitos neurais, utilizando a expressão de receptores em oócitos de Xenopus sp. Os receptores foram: GABAérgicos $A$, glicinérgicos $\alpha 1$, nicotínicos $\alpha 4 \beta 2$, e glutamatérgicos AMPA e NMDA. Segundo os autores, a uretana em concentração anestésica (50\%) potencializou a função dos receptores GABAA (+23\%), $\alpha 1$ (+33\%) e $\alpha 4 \beta 2$ (+15\%), enquanto inibiu NMDA (-10\%) e AMPA $(-18 \%)$. Hara e Harris ${ }^{251}$ compararam seus resultados com estudos equivalentes que haviam testado outros anestésicos e sedativos. Barbitúricos como pentobarbital e tiopental potencializam a função de receptores GABAérgicos em mais de $100 \%$, enquanto inibem AMPA (aproximadamente $-50 \%$ ). Os voláteis halotano e isoflurano também potencializam em mais de $100 \%$ os receptores GABAérgicos e glicinérgicos, enquanto inibem os nicotínicos (cerca de -50\%). Outro potencializador de receptores GABAérgicos é o hipnótico propofol, que não afeta significativamente os demais receptores. Por fim, a cetamina inibe receptores NMDA $(-80 \%)$ e também nicotínicos $(-50 \%)$. Como se vê, a atuação da uretana é comparativamente mais fraca e homogênea ao longo dos receptores testados, o que favorece sua viabilidade para medidas eletrofisiológicas in vivo ${ }^{251}$.

Os mecanismos pelos quais a uretana induz as ondas lentas da anestesia não são totalmente conhecidos, ainda mais considerando-se a baixa especificidade de seus efeitos sobre os sistemas neurotransmissores. Mesmo assim, em ratos anestesiados com uretana, Horner e Kubin ${ }^{252}$ mostraram que a aplicação do agonista colinérgico carbacol na formação reticular pontina (incluindo PPT/LDT) promove as manifestações musculares e eletrográficas típicas do sono paradoxal. Neste mesmo sentido, Clement et al. ${ }^{250}$ observaram que a atividade oscilatória lenta promovida pela uretana se alterna espontaneamente com episódios de ondas rápidas, e que tais episódios são acompanhados por perda de tônus muscular, similarmente aos ciclos de sono paradoxal encontrados no sono natural. Détári et al. $^{246}$ e Balatoni e Détári ${ }^{253}$ indicaram que, mesmo sob uretana, o prosencéfalo basal continua sensível à estimulação elétrica do PPT e núcleo dorsal da rafe. Coerentemente, 
Dringenberg e Olmstead ${ }^{249}$ mostraram que a estimulação do PPT de ratos anestesiados com uretana promove oscilações rápidas no neocórtex, e que tais oscilações são bloqueáveis por inativação reversível (injeções locais de lidocaína) no prosencéfalo basal e/ou tálamo. Finalmente, Toth et al. ${ }^{254}$ mostraram que a aplicação tópica de agonistas colinérgicos sobre a superfície cortical de ratos diminui as oscilações lentas promovidas pela uretana. Conjuntamente, estes achados indicam que o sistema colinérgico tem suas funções relativamente preservadas sob anestesia por uretana. Portanto, tendo em vista o contexto fisiológico levantado pela presente revisão, sugere-se que a anestesia por uretana também pode ser útil à exploração do controle colinérgico sobre a plasticidade talamocortical. 
O CPF é crucial à flexibilidade com que o indivíduo direciona sua atenção e toma decisões. Isto condiz com o conjunto de aferências que ele centraliza, algumas das quais pertencentes ao chamado sistema límbico. Particularmente no CPFm de roedores, homólogo ao CPFdl primata, as principais aferências corticais provêm dos córtices rinais, subículo e CA1 hipocampal ${ }^{118}$. Por sua vez, as principais aferências diencefálicas emergem dos núcleos mamilares do hipotálamo, núcleos talâmicos da linha média e $\mathrm{Tmd}^{118}$. Outras importantes aferências subcorticais se originam dos núcleos basais da amígdala, partes do prosencéfalo basal, substância cinzenta periaquedutal, ATV, núcleos da rafe e locus coeruleus ${ }^{118}$.

A manipulação do CPFm por lesão ou estimulação farmacológica é útil ao estudo de suas funções cognitivas. Tais funções podem ser monitoradas por neuroimagem ou registro eletrofisiológico, em busca de padrões temporais e espaciais da atividade neuronal. Contudo, tendo em vista que o CPFm compartilha funções com as estruturas que o inervam, um cenário fisiológico integrado requer a investigação da rede de aferências ao CPFm. A estimulação elétrica de vias convergentes tem o potencial de fornecer detalhes relevantes acerca das interações excitatórias e inibitórias que ocorrem dentro do CPFm. Estas interações podem, ainda, ser avaliadas sob contextos neuroquímicos que imitem de maneira controlada diferentes estados funcionais do encéfalo.

Dentre as vias aferentes ao CPFm, a mais estudada se origina da região posterior da formação hipocampal. A partir desta região, células piramidais do CA1 enviam projeções excitatórias ao CPFm, tanto diretamente, quanto através de células-relé no subículo ${ }^{134,255,256}$. A via hipocampo-CPFm atrai interesse pelo fato de sua plasticidade sináptica dependente de NMDA $^{257-261}$ ser associada à memória de trabalho ${ }^{258}$, reversão da depressão maior ${ }^{262,263}$, e esquizofrenias $^{264}$. Na busca por particularidades da plasticidade hipocampo-CPFm, uma estratégia relevante seria a de compará-la com a plasticidade intra-hipocampal, que é melhor conhecida. Esta indagação atraiu o interesse de Romcy-Pereira e Pavlides $(2004)^{265}$, que compararam os efeitos da privação de sono paradoxal sobre a PLD hipocampo-CPFm e intra-hipocampal. Os autores relataram que a privação do sono paradoxal acelerou o decaimento da PLD intra-hipocampal, mas prolongou a PLD hipocampo-CPFm por até $48 \mathrm{~h}$. Além de mostrarem que a plasticidade pré-frontal segue uma dinâmica diferente da hipocampal, estes resultados indicam que o sono paradoxal tem efeitos de longo prazo sobre a influência que o CPFm recebe do hipocampo. 
A atividade oscilatória do sono paradoxal ocorre num contexto neuroquímico dominado pela modulação colinérgica ${ }^{240,241}$. Portanto, os resultados de Romcy-Pereira e Pavlides ${ }^{265}$ sugeriram indiretamente que a ativação colinérgica global pode regular a plasticidade sináptica hipocampo-CPFm. A possibilidade ainda não havia sido experimentada, embora a participação colinérgica no processamento pré-frontal de longo prazo estivesse parcialmente explorada por técnicas não eletrofisiológicas ${ }^{188}$. Diante desta lacuna, nosso laboratório iniciou uma linhagem de estudos examinando os efeitos da ativação colinérgica sobre a PLD e DLD na via hipocampo-CPFm ${ }^{261,266,267}$. Anestesiando ratos com uretana e recrutando globalmente receptores muscarínicos por injeção sistêmica ou intraventricular de PILO (concentração sub-epiléptica), os resultados dos trabalhos mostraram que: (1) PILO prolonga a manutenção da PLD tardia ( 2 h após EAF) ${ }^{266}$; (2) PILO favorece uma DLD estável e dependente de NMDA por pelo menos $4 \mathrm{~h}$ após $\operatorname{EBF}^{261}$; (3) o fortalecimento da PLD por PILO é atenuado por LiCl aplicado sistemicamente no dia anterior $^{267}$; e (4) o favorecimento da DLD por PILO é aumentado pelo mesmo prétratamento com $\mathrm{LiCl}^{267}$. Conjuntamente, os resultados indicam que, no contexto da ativação muscarínica global, a via hipocampo-CPFm tem a plasticidade sináptica favorecida de modo bidirecional, ou seja, tanto PLD quanto DLD são fortalecidas quando EAF e EBF são aplicadas durante os efeitos da PILO.

Estes achados de nosso laboratório ajudam a esclarecer regulações de longo prazo da função pré-frontal sob ativação colinérgica. Mesmo assim, eles dizem respeito somente a uma parte das influências centrípetas ao CPFm. Além disto, eles se somam à série de estudos internacionais sobre a plasticidade hipocampo-CPFm que vêm se acumulando desde $1990^{257}$, formando um conhecimento bem maior que o relacionado às demais conexões do CPFm. Uma destas conexões negligenciadas está contida no circuito bidirecional Tmd$\mathrm{CPFm}^{129}$. A importância deste circuito para a função pré-frontal se deve ao fato de ele ser a alça talamocortical mais densa envolvendo o $\mathrm{CPFm}^{129}$. Considerando-se que as funções talamocorticais básicas incluem a reverberação excitatória sob as oscilações prosencefálicas $^{41,54}$, a coesão entre processamentos corticais de áreas distantes ${ }^{37,38}$, e o provimento de sinais aferentes individualmente mais eficazes do que os corticocorticais ${ }^{12,38}$, parece claro que o Tmd pode participar ativamente da cognição pré-frontal. De fato, tanto a pesquisa experimental quanto a clínica reforçam que Tmd e CPFm compartilham funções e disfunções comportamentais ${ }^{115-117,124-126,160-164}$. 
Apesar de a plasticidade talamocortical ser máxima num período curto da vida pósnatal, circuitos talamocorticais adultos retêm certa plasticidade, especialmente na presença de neuromoduladores ${ }^{29-31}$. Porém, no caso do circuito Tmd-CPFm, ainda não há estudos relatando efeitos de quaisquer neuromoduladores sobre sua plasticidade sináptica. Aliás, os poucos trabalhos que induziram plasticidade sináptica Tmd-CPFm foram produzidos por um único grupo francês ${ }^{149,150,268,269}$, que encontrou uma relação entre a DLD e a resistência à reversão do medo condicionado. Nós temos em vista que o circuito Tmd-CPFm e a via hipocampo-CPFm compartilham células em comum no CPFm, o que foi demonstrado por estudos de anatomia e evocação de respostas unitárias ${ }^{270-273}$. Portanto, é possível que a plasticidade Tmd-CPFm e hipocampo-CPFm regulem-se mutuamente, e tal regulação pode ser sensível ao contexto oscilatório dependente do sistema colinérgico.

Na tentativa de: (1) incrementar o conhecimento das comodulações que convergem ao CPFm; (2) tornar mais nítida a plasticidade em rede centralizada pelo CPFm; e (3) avaliar tal plasticidade sob contextos oscilatórios similares aos do alerta ou sono paradoxal, o objetivo geral deste trabalho foi o de induzir plasticidade sináptica no circuito Tmd-CPFm durante ativação colinérgica global e temporária. O presente estudo também avança na comparação das funções globais muscarínicas e nicotínicas, esclarecendo sua participação diferencial na indução da plasticidade pré-frontal. Em meio a outros achados de nosso grupo, esperamos contribuir ao entendimento do CPF funcional e disfuncional, propondo implicações para memória de trabalho, atenção, armazenamento de estratégias comportamentais, dependência química e transtornos neuropsiquiátricos.

\subsection{Objetivos específicos}

(1) Promover e controlar a ativação colinérgica temporária de PCLs corticais e talâmicos, através da injeção intraventricular de PILO ou NIC em ratos anestesiados com uretana.

(2) Aplicar EAF ou EBF no Tmd durante os efeitos de PILO ou NIC, registrar PPSCs do CPFm evocados por pulsos no Tmd durante $4 \mathrm{~h}$, e monitorar eventual PLD ou DLD. 


\subsection{Sujeitos}

Utilizamos ratos Wistar machos adultos pesando $250-400$ g, provenientes do Biotério Central do Campus de Ribeirão Preto, USP. Eles foram alojados em grupos de 2-4 indivíduos dentro de caixas plásticas padrão $(40 \times 33 \times 18 \mathrm{~cm})$ acamadas com serragem de madeira, e tiveram livre acesso a ração e água. A temperatura do biotério foi mantida em $23-25^{\circ} \mathrm{C}$, com período claro começando às 07:00 e período escuro às 19:00. O projeto de pesquisa submetido à agência de fomento (FAPESP) também foi apresentado à Comissão de Ética em Experimentação Animal (CETEA) da FMRP-USP, tendo seus procedimentos experimentais aprovados sob o protocolo 125/2008.

O número total de ratos usados no doutorado foi 190 . Destes, $87(45,8 \%)$ foram incluídos nas análises aqui apresentadas, 86 (45,3\%) foram descartados por causa de intercorrências (posicionamento incorreto de implantes, ruído no sinal eletrofisiológico, ou irregularidade dos PPSCs no CPFm), e 17 (8,9\%) morreram durante o procedimento cirúrgico ou etapas iniciais do experimento. Especificamente nos experimentos principais de plasticidade sináptica, três ratos de grupos distintos morreram no último quarto de registro eletrofisiológico, mas foram aproveitados sem afetarem significativamente as médias, nem as medidas de variação em torno dela.

\subsection{Cirurgia e eletrofisiologia}

\subsubsection{Estereotaxia e cânula}

Todos os experimentos foram realizados sob anestesia permanente. Para tanto, utilizamos aplicação única do anestésico uretana (Sigma-Aldrich, EUA) dissolvido em solução salina $(\mathrm{NaCl}$ 0,9\%) na concentração de $50 \%$. O anestésico foi injetado pela via intraperitoneal na dose de 1,2 mg/Kg. Após verificação da anestesia por pinçamento da cauda, foi feita a tricotomia do escalpo e fixação da cabeça em aparelho estereotáxico (David Kopf, EUA). 
Repousamos o rato sobre uma placa aquecedora metálica adaptada ao aparelho estereotáxico (Insight, Brasil), de modo a manter sua temperatura em $37 \pm 0,5{ }^{\circ} \mathrm{C}$, com monitoramento contínuo por termômetro retal.

Após incisão longitudinal do escalpo e remoção do periósteo, marcamos com caneta hidrocor os três pontos estereotáxicos de interesse sobre o crânio (Fig. 4):

- CPFm esquerdo (3,00 mm anterior ao bregma, 0,35 mm lateral à linha média),

- ventrículo lateral direito, VL (0,50 $\mathrm{mm}$ posterior ao bregma, 1,35 $\mathrm{mm}$ lateral à linha média),

- Tmd esquerdo (1,90 $\mathrm{mm}$ posterior ao bregma, 0,35 $\mathrm{mm}$ lateral à linha média).

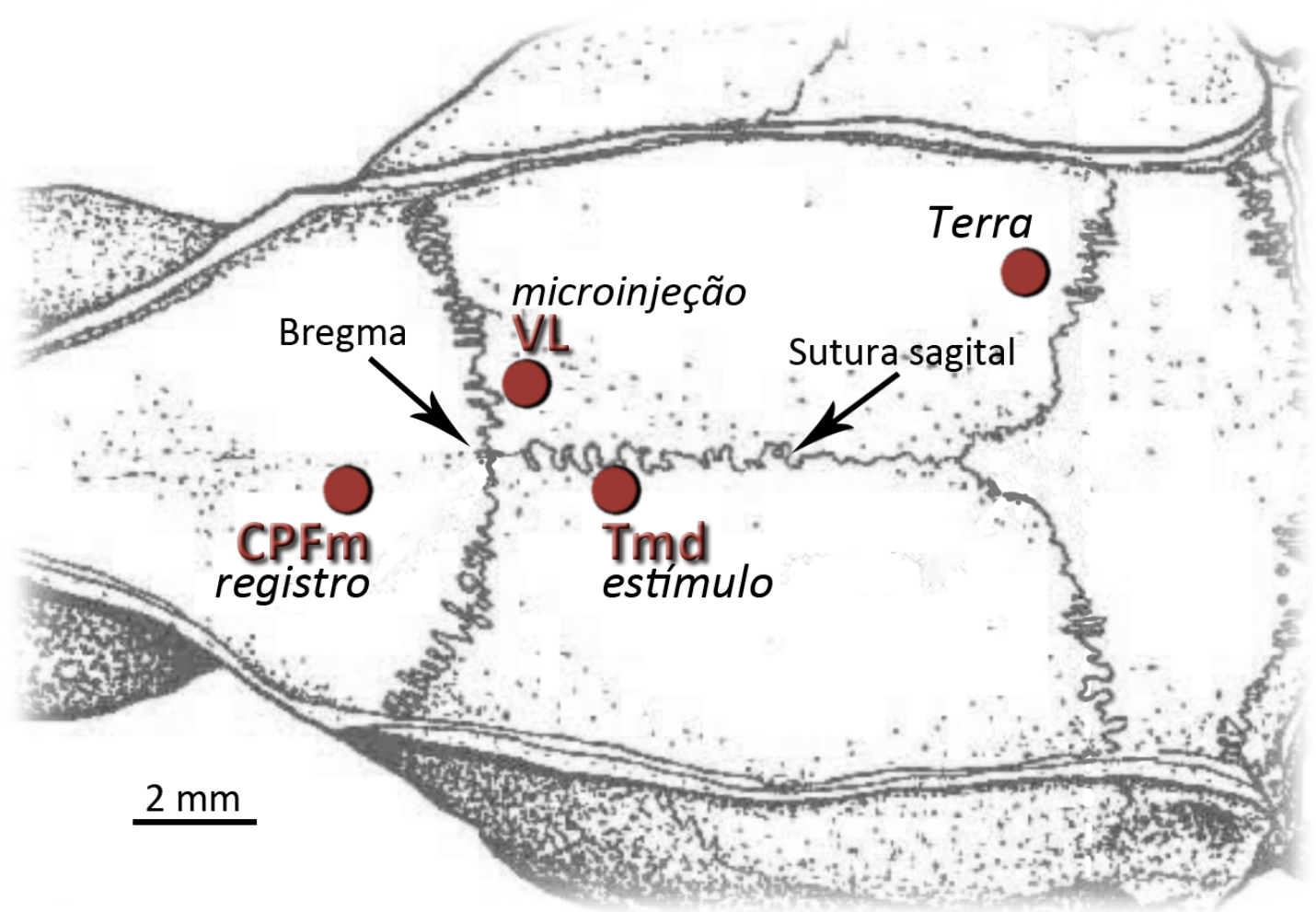

Figura 4. Perfurações feitas ao crânio dos ratos para acesso às regiões encefálicas de interesse. As coordenadas ântero-posteriores se referiram ao bregma, e as médio-laterais à linha média, grosseiramente coincidente com a sutura sagital (ver valores das coordenadas no texto). Os orifícios correspondentes ao CPFm e Tmd receberam, respectivamente, os eletrodos de registro e estimulação. $O$ orifício correspondente ao ventrículo lateral recebeu a cânula de microinjeção, fixada ao crânio pela construção de uma base acrílica. Por fim, a perfuração mais posterior não obedeceu a coordenadas precisas, e recebeu um microparafuso ligado a um fio de aterramento. A imagem do crânio foi obtida da referência 119.

As coordenadas seguem o atlas de Paxinos e Watson $(2007)^{119}$ com pequenas adaptações aos ratos reproduzidos em nosso biotério central. Um quarto orifício foi 
perfurado sobre o córtex parietal sem precisão de coordenadas, para implante de um microparafuso conectado ao fio de aterramento. Por fim, perfuramos gentilmente as meninges sob o orifício correspondente ao VL para implante de uma cânula de aço inoxidável feita manualmente a partir de uma agulha comum (calibre 23-gauge, $12 \mathrm{~mm}$ de comprimento). A extremidade da cânula foi posicionada $2,53 \mathrm{~mm}$ abaixo do nível das meninges, isto é, aproximadamente $1,00 \mathrm{~mm}$ acima do VL. A cânula foi presa ao crânio com uma pequena base acrílica esculpida com pincel e solvente. Não houve necessidade de construção de capacete acrílico abarcando os eletrodos, nem sutura do escalpo. Afinal, utilizamos a preparação de anestesia permanente, em que o animal é mantido preso ao aparelho estereotáxico durante todo o experimento.

\subsubsection{Eletrodo de registro e eletrencefalograma}

Preparamos o eletrodo monopolar de registro manualmente, a partir de um pino de ouro e um fio único de tungstênio (60 $\mu \mathrm{m}$ de diâmetro) eletricamente isolado por revestimento de teflon ( $A-M$ Systems, EUA). Uma das extremidades do fio teve seu revestimento removido para ser soldado ao pino de ouro (Fig. 5). Por sua vez, a outra extremidade foi cortada diagonalmente para a formação de um pequeno bisel que facilitasse o implante tecido adentro. Procuramos manter o eletrodo limpo e conservado para que pudesse ser reutilizado ao longo dos experimentos, e no caso da necessidade de renovação procuramos padronizar o comprimento ( $10-15 \mathrm{~mm}$ ) do novo fio.

O eletrodo monopolar teve seu pino de ouro conectado a um cabo comum, preso a um dos braços do aparelho estereotáxico. Este cabo, por sua vez, foi ligado a um préamplificador analógico P55 (Grass Technologies, EUA) alimentado pela corrente contínua de uma bateria alcalina de $9 \mathrm{~V}$, reduzindo-se o ruído de $\sim 60 \mathrm{~Hz}$ da corrente alternada predial. Regulamos o pré-amplificador para amplificar o sinal em 100 vezes e filtrá-lo na faixa de frequências de 0,3-1.000 Hz, uma vez que viríamos a coletar sinais ora na escala de segundos (PCLs, eletrencefalograma profundo), ora na escala de dezenas de milissegundos (PPSCs, respostas pré-frontais de campo evocadas pela estimulação talâmica). O conjunto formado

pelo aparelho estereotáxico, eletrodo, respectivo cabo e pré-amplificador foi 
compactamente organizado no interior de uma gaiola de Faraday (Insight, Brasil) com abertura frontal para a cirurgia e manipulação pelo experimentador (Fig. 5). A gaiola, construída a partir de uma malha metálica, foi na maior parte dos experimentos suficiente para reduzir substancialmente os ruídos elétricos, tornando desnecessário acionar o filtro notch $(\sim 60 \mathrm{~Hz})$ disponível no pré-amplificador analógico.

O canal de saída do pré-amplificador foi ligado a um conversor analógico-digital PowerLab/16S (ADInstruments, Austrália) externo à gaiola de Faraday, através de um cabo do tipo BNC (Fig. 5). Neste aparelho, o sinal analógico proveniente do eletrodo monopolar viria a ser digitalizado na forma de pontos amostrados a $10 \mathrm{KHz}$ (PPSCs) ou $200 \mathrm{~Hz}$ (PCLs), antes de ser finalmente transferido a um computador. Através dos programas computacionais Scope ou LabChart fornecidos pelo mesmo fabricante (ADInstruments, Austrália), configuramos modos de visualização adequados para coleta de PCLs e PPSCs.

Com o eletrodo monopolar a postos no aparelho estereotáxico, restava determinar qual altura no eixo dorsoventral viria a ser usada para seu implante. Para tanto, regulamos o braço do aparelho estereotáxico lentamente para baixo, até que a extremidade do eletrodo tocasse levemente a superfície da dura-máter sob o orifício do crânio correspondente ao CPFm esquerdo. Para a confirmação deste toque, acompanhamos o sinal ruidoso pelo programa computacional até que ele se convertesse no sinal "limpo" dos PCLs superficiais, confirmando aquela altura como nível zero de referência à coordenada dorsoventral. Em seguida, o eletrodo monopolar foi novamente elevado, com afastamento suficiente para perfurarmos gentilmente as meninges com uma agulha comum e, então, definitivamente abaixado para implante $3,20 \mathrm{~mm}$ abaixo do nível das meninges, na altura correspondente à área pré-límbica do CPFm (Fig. 5). 
A
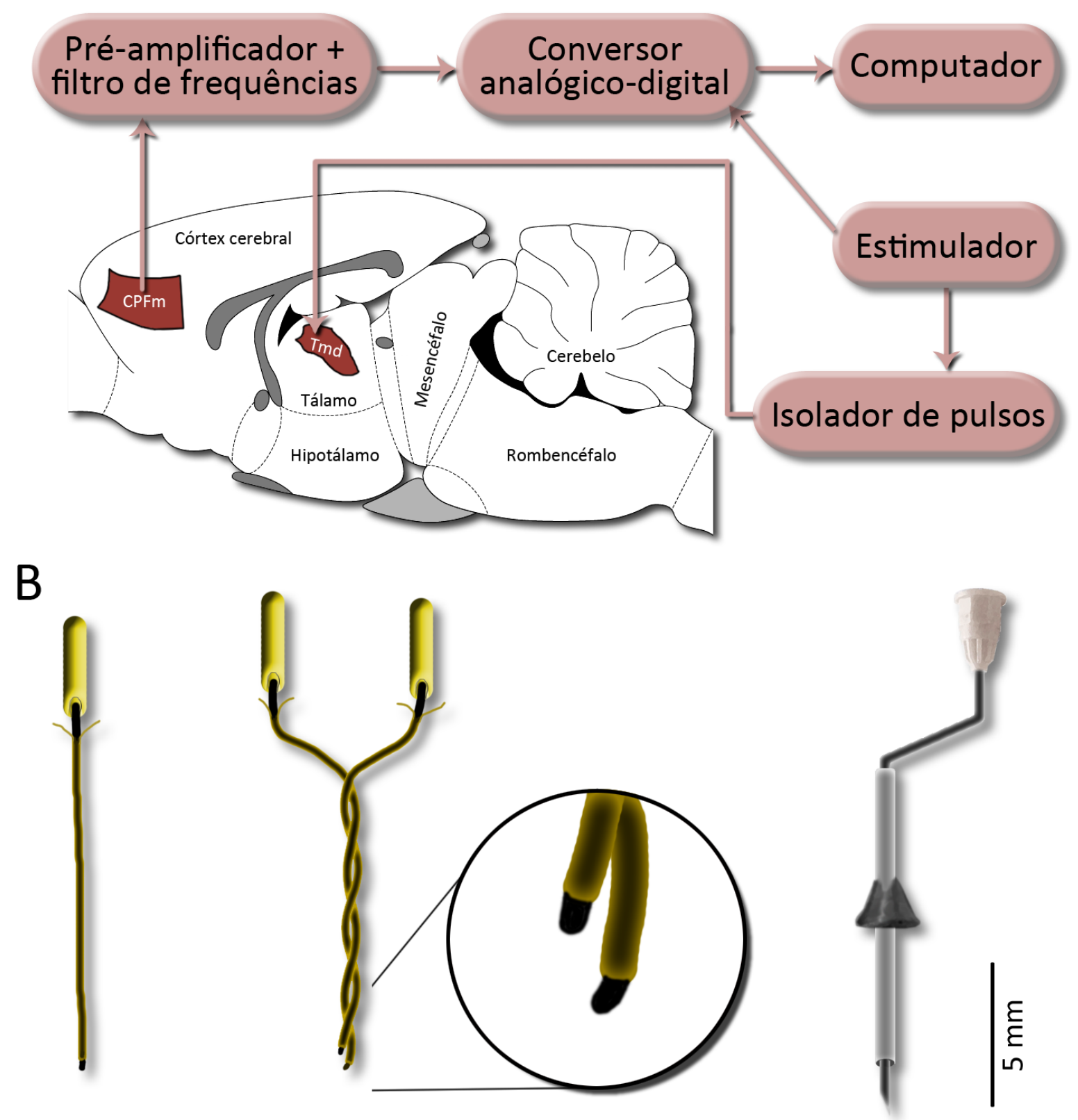

Figura 5. Representação esquemática do equipamento de eletrofisiologia, eletrodos e cânula de microinjeção. (A) Do estimulador parte um cabo ao isolador fotoelétrico de pulsos, que por sua vez transmite os pulsos monofásicos ao eletrodo bipolar implantado no Tmd. Para cada pulso é evocado um PPSC no CPFm, cujo sinal analógico é captado pelo eletrodo monopolar e recebido pelo pré-amplificador com filtro de frequências. Uma vez filtrado $(0,3-1.000 \mathrm{~Hz})$ e amplificado $(100 \mathrm{x})$, o sinal analógico é conduzido ao conversor analógico-digital para amostragem em pontos. O registro da janela temporal $(120 \mathrm{~ms})$ contendo o PPSC é desencadeado pelo sinal direto do estimulador ao conversor analógico-digital, que se antecipa ao pulso emitido no Tmd em 20 ms. Uma vez registrado dentro da janela temporal, o PPSC é armazenado em computador. (B) Da esquerda para a direta estão o eletrodo monopolar de registro, o eletrodo bipolar de estimulação e a cânula de aço atravessada pela agulha de microinjeção. Os pinos de ouro (em amarelo) se conectam aos cabos do sistema representado na parte superior da figura. Os fios dos eletrodos são de tungstênio (60 $\mu \mathrm{m}$ de diâmetro) revestidos com isolante elétrico (teflon). Note-se a remoção da cobertura de teflon nas extremidades, para soldagem aos pinos de ouro, ou captação do sinal eletrofisiológico. No eletrodo bipolar, as pontas são separadas por aproximadamente $500 \mu \mathrm{m}$ para passagem de corrente elétrica monofásica. A gota de solda presa ao meio da cânula ajuda na sua fixação ao crânio. 


\subsubsection{Eletrodo de estimulação, pulsos elétricos e PPSCs}

A preparação do eletrodo de estimulação foi similar à do eletrodo de registro, porém com dois pinos de ouro e dois fios de tungstênio trançados entre si, formando uma extremidade bipolar para passagem de corrente elétrica monofásica (Fig. 5). Os dois pinos de ouro do eletrodo bipolar foram conectados a um par de cabos, por sua vez presos ao outro braço do aparelho estereotáxico. Para fins de determinação do nível zero dorsoventral, um dos cabos correspondentes ao eletrodo bipolar foi provisoriamente conectado ao mesmo pré-amplificador mencionado acima, repetindo-se os procedimentos para coleta dos PCLs superficiais. Depois de definida a altura dorsoventral com alvo no Tmd o eletrodo bipolar não foi imediatamente implantado. Ao invés disto, foi temporariamente deixado fora do encéfalo antes da conexão de seus dois cabos ao sistema de estimulação, também externo à gaiola de Faraday.

O sistema de estimulação foi composto por: (1) estimulador S88 (Grass Technologies, EUA); (2) unidade para isolamento fotoelétrico de estímulos PSIU6 (Grass Technologies, EUA); (3) cabo especial de conexão entre S88 e PSIU6; (4) par de cabos comuns para conexão entre PSIU6 e os cabos presos ao aparelho estereotáxico (diretamente ligados ao eletrodo bipolar); e (5) cabo BNC de conexão entre S88 e PowerLab/16S, para sincronização temporal entre o pulso aplicado no Tmd e o registro dos PPSCs em janelas de 120 ms (Fig. 5). Através do estimulador S88 regulamos os parâmetros dos pulsos elétricos, isolados da interferência elétrica predial por meio da unidade fotoelétrica PSIU6. Configuramos a estimulação padrão na forma de pulsos retangulares (duração de $200 \mu$ s, intensidade de 150-200 $\mu \mathrm{A}$ ) emitidos a cada $20 \mathrm{~s}(0,05 \mathrm{~Hz})$. Com a estimulação padrão acionada, aí sim o eletrodo bipolar foi lentamente implantado em etapas de $200 \mu \mathrm{m}$. A cada avanço do eletrodo bipolar no seu trajeto dorsoventral em direção ao Tmd, observamos a evocação de PPSCs pré-frontais. Assim, pudemos refinar o posicionamento dorsoventral não só de acordo com a coordenada estereotáxica (4,80-5,20 mm abaixo das meninges), mas também conforme a aparência e regularidade dos PPSCs (Fig. 10). Os PPSCs foram individualmente registrados pelos softwares Scope ou LabChart, contidos nas janelas temporais de $120 \mathrm{~ms}$ acionadas pela comunicação do estimulador ao conversor analógico-digital (Fig. 5). O artefato resultante do pulso foi posicionado aos $20 \mathrm{~ms}$, de modo que os $100 \mathrm{~ms}$ restantes registrassem o PPSC. 


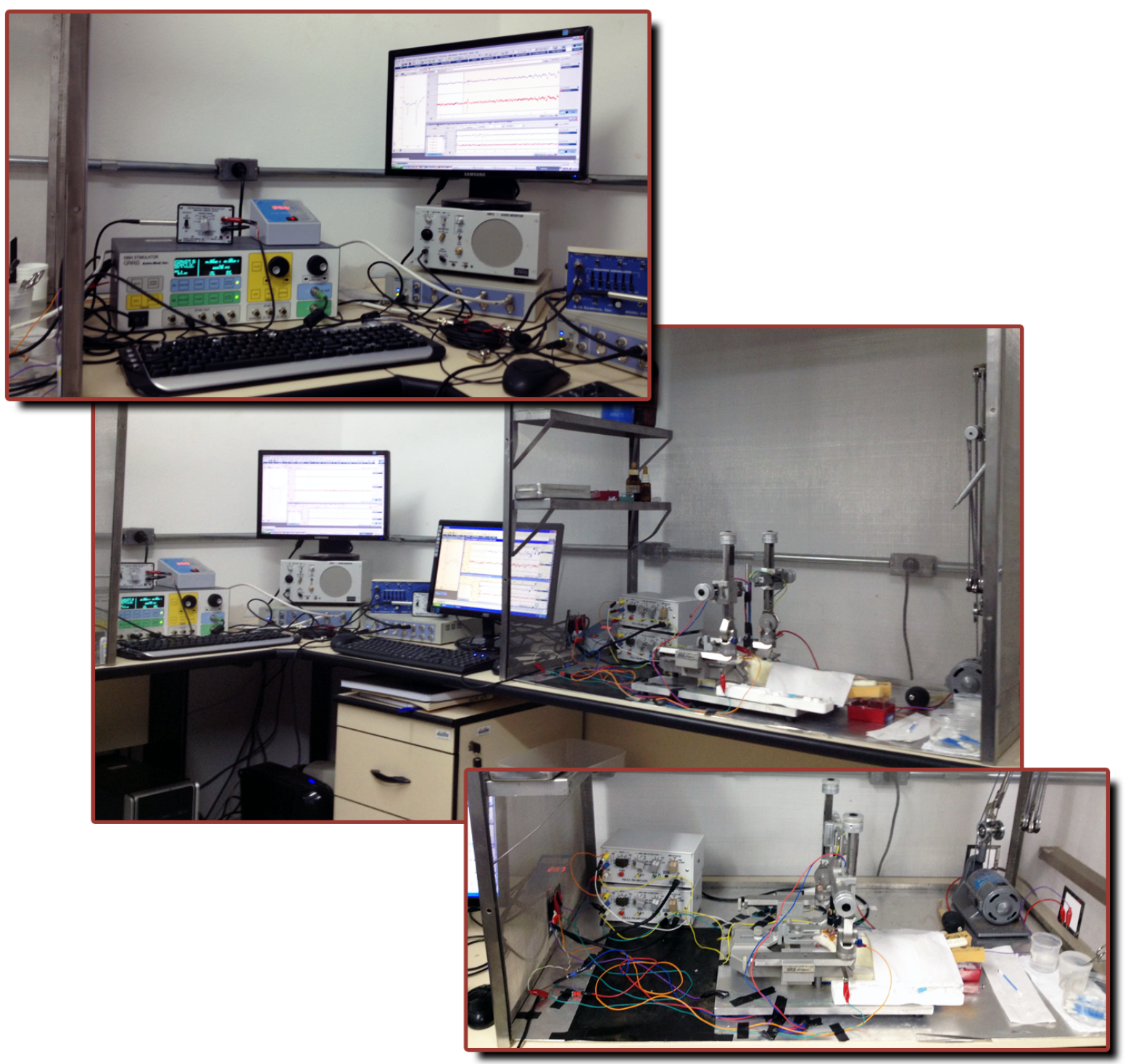

Figura 6. Visão geral dos equipamentos de eletrofisiologia. A imagem central mostra, em sua parte esquerda, um conjunto de aparelhos compartilhados por dois sistemas experimentais, sendo que somente um sistema (incluindo a gaiola de Faraday à direita) está mostrado na totalidade. A imagem superior detalha o conjunto de aparelhos: à esquerda está o estimulador, sobre o qual repousam o isolador fotoelétrico de pulsos e o termostato digital que controla a temperatura da placa aquecedora. À direita está o monitor de vídeo, mostrando o software de registro de PPSCs e PCLs. O monitor de vídeo repousa sobre um monitor de áudio, útil ao monitoramento de ruídos da rede elétrica. Por fim, o monitor de áudio está sobre o conversor analógico-digital. A imagem inferior detalha o arranjo interno à gaiola de Faraday, mostrando o par de préamplificadores (à esquerda) e o aparelho estereotáxico com rato anestesiado.

\subsection{Drogas colinérgicas}

Empregamos duas drogas, já mencionadas em nossa revisão da literatura: PILO, um agonista muscarínico não-seletivo com particular afinidade à família de receptores $\mathrm{M}_{1}{ }^{218-222}$, 
e NIC, um agonista nicotínico não-seletivo, com afinidade a receptores $\alpha 4 \beta 2$ e $\alpha 7$, que são os subtipos de receptores nicotínicos neurais mais prevalentes ${ }^{223-225}$. Utilizamos PILO na forma do sal cloridrato de pilocarpina (Sigma-Aldrich, EUA), que dissolvemos em líquido cerebrospinal artificial em concentração padronizada previamente por nosso laboratório: 40 $\mathrm{nmol} / \mu \mathrm{L}$ (para justificativa desta concentração, vide abaixo seção de experimentos preparatórios). Utilizamos NIC na forma de outro sal, hidrogeno-tartarato de (-)-nicotina (Sigma-Aldrich, EUA), para dissolução no mesmo líquido cerebrospinal em concentração que também foi experimentalmente testada, mas desta vez como parte deste doutorado: 320 $\mathrm{nmol} / \mu \mathrm{L}$ (Fig. 9). O líquido cerebrospinal artificial consistiu em solução aquosa de sais (em $\left.\mathrm{mM}: \mathrm{CaCl}_{2} 1,2 ; \mathrm{KCl} 2,7 ; \mathrm{MgCl}_{2} 1,0 ; \mathrm{NaCl} 135,0\right) \mathrm{com} \mathrm{pH} 7,3$ à temperatura ambiente. $\mathrm{Na}$ ausência de PILO e NIC, o líquido cerebrospinal serviu como substância controle, que chamaremos de VEIC daqui em diante. O volume de PILO, NIC e VEIC injetado dentro do ventrículo foi padronizado em $1 \mu \mathrm{L}$ ao longo dos experimentos.

\subsection{Desenho experimental}

3.4.1. Polaridade de estimulação, curva de entrada/saída e atividade basal

Uma vez estabelecido o implante do eletrodo bipolar, testamos a eliciação de PPSCs sob as duas polaridades de estimulação, isto é, com a corrente monofásica partindo ora de um dos fios trançados, ora do outro. A polaridade é regulável através de uma chave no isolador de pulsos PSIU6. Dependendo do sujeito, os testes ajudavam a definir a polaridade capaz de evocar os PPSCs com mais regularidade. Embora diferentes polaridades de estimulação produzissem artefatos de aparências distintas, as características mais importantes dos PPSCs (latências dos picos e direção negativa da deflexão) não se alteravam. Uma vez definida a polaridade de estimulação, ela não voltou a ser manipulada até o fim da coleta de dados de cada rato. 
A

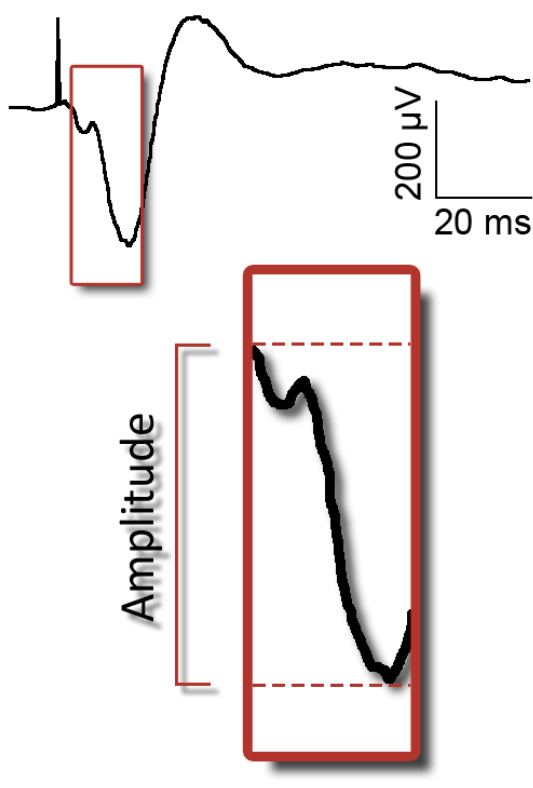

B

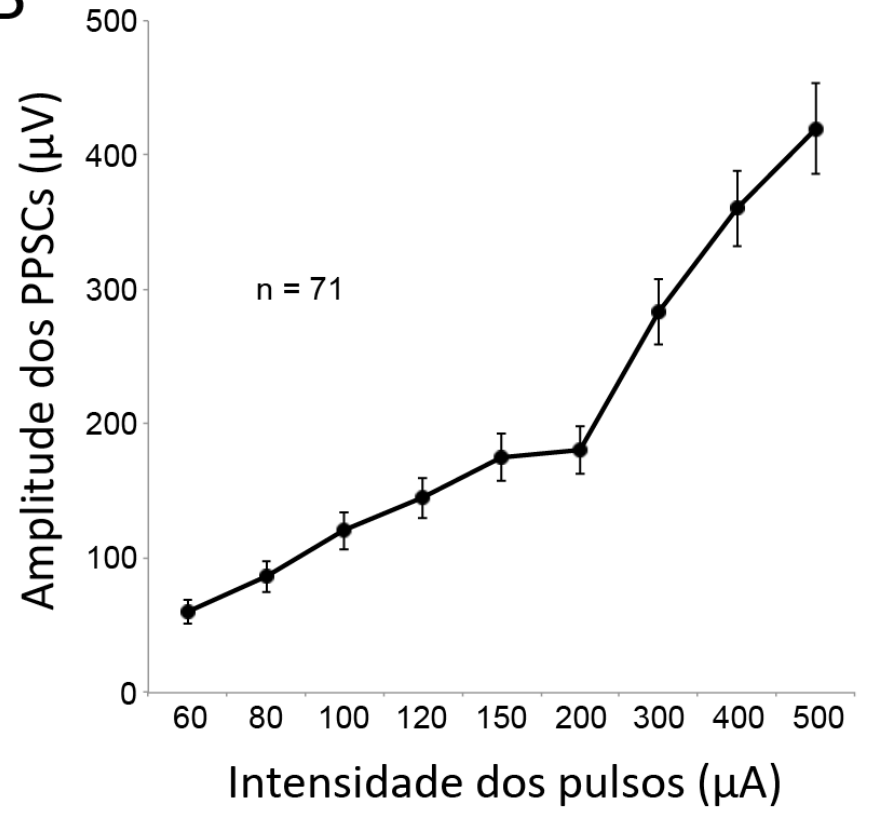

Figura 7. PPSC típico, sua medida de amplitude e curva E/S. (A) O PPSC típico está sob um quadro vermelho que representa o intervalo temporal automatizado para o cálculo da amplitude (macro). Este cálculo consistiu na diferença entres os valores dos picos negativo e positivo (centenas de microvolts). Em tese, a deflexão negativa representa a despolarização da população de células ao redor do eletrodo de registro, e consequente perda relativa de cátions do meio extracelular. Esta resposta de campo (ordem de dezenas de milissegundos), que não necessariamente indica potenciais de ação pós-sinápticos (ordem de milissegundos), é o objeto básico dos estudos em plasticidade sináptica. (B) A curva E/S mostra como a amplitude de PPSCs pré-frontais (eixo de ordenadas) mudou conforme a intensidade dos pulsos elétricos aplicados no Tmd (eixo de abscissas). Curvas E/S similares à da figura, porém individuais, foram obtidas antes de cada experimento, para definição da intensidade dos pulsos de acordo com a eficácia de evocação dos PPSCs. Nesta figura, agrupamos as curvas E/S de todos os experimentos de plasticidade sináptica, para mostrarmos que pulsos a 200-300 $\mu \mathrm{A}$ foram suficientes para evocar PPSCs com eficácia intermediária. Os dados são mostrados como média \pm erro padrão.

Definida a polaridade, mantivemos a estimulação de $0,05 \mathrm{~Hz}$ usada durante 0 implante do eletrodo bipolar, porém controlando a intensidade da corrente de maneira crescente para obtenção de uma curva de entrada/saída (E/S). Em mais detalhes, emitimos três pulsos para cada uma das seguintes intensidades: 60, 80, 100, 120, 150, 200, 300, 400 e $500 \mu \mathrm{A}$. Os três PPSCs eliciados em cada intensidade foram promediados e a amplitude dos PPSCs médios foi calculada pela diferença entre o valor em microvolts do pico positivo e o valor do pico negativo (eixo de ordenadas). A Figura 7 ilustra a medida de amplitude de um PPSC representativo, além de mostrar a curva E/S média de todos os sujeitos incluídos nas análises de plasticidade sináptica. A curva E/S foi importante para determinar uma intensidade de estimulação que viria a ser usada no resto do experimento. A intensidade deveria ser suficiente para evocar PPSCs com regularidade, porém sem recrutar uma resposta de campo tão forte que ocultasse a plasticidade sináptica. Para cada sujeito, a intensidade escolhida (200-300 $\mu \mathrm{A})$ foi aquela capaz de evocar PPSCs com $60-70 \%$ da 
amplitude máxima plotada na curva E/S. Esta porcentagem foi definida segundo a literatura ${ }^{149,150}$ e nossas próprias observações quanto à regularidade da evocação de PPSCs.

Utilizando a intensidade definida pela curva E/S e mantida a estimulação com pulsos a cada $20 \mathrm{~s}$, iniciamos a coleta dos PPSCs pré-frontais basais (linha de base), totalizando 90 PPSCs individualmente armazenados pelos softwares Scope ou LabChart ao longo de $30 \mathrm{~min}$.

\subsubsection{Injeção das drogas com registro da atividade oscilatória}

Após a coleta dos PPSCs basais, desativamos a emissão de pulsos, desconectamos o eletrodo bipolar do sistema de estimulação e provisoriamente conectamos um de seus cabos a um segundo pré-amplificador analógico P55, colocado sobre o primeiro. 0 canal de saída do segundo pré-amplificador foi conectado a um canal de entrada ocioso do conversor analógico-digital, permitindo temporariamente a coleta de PCLs corticais e talâmicos simultaneamente a partir dos dois eletrodos. Adequamos as configurações dos softwares Scope ou LabChart de modo a substituir o registro de PPSCs discretos (uma janela de $120 \mathrm{~ms}$ a cada 20 s) pelo registro de PCLs contínuos (janelas de $10 \mathrm{~s}$ em sequência ininterrupta). Em seguida, cuidadosamente inserimos uma agulha gengival (30-gauge) através da cânula, evitando-se a perturbação dos eletrodos. Conforme a Figura 4, fizemos um desvio com duas dobras na agulha de modo que sua extremidade repousasse $1 \mathrm{~mm}$ abaixo da extremidade da cânula, atingindo-se a luz do VL para microinjeção da droga (solução de PILO, NIC, ou VEIC). Previamente ao seu implante via cânula, a agulha fora conectada a uma microsseringa de 10 $\mu \mathrm{L}$ (Hamilton, EUA) através de um tubo flexível de polietileno. Todo este sistema hidráulico fora preenchido com a droga evitando-se bolhas de ar. Uma vez posicionada a agulha dentro da cânula, iniciamos o registro de PCLs continuamente por um período de $6 \mathrm{~min}$. Tal período foi dividido em três blocos de $2 \mathrm{~min}$, e a droga foi vagarosamente injetada ( $1 \mu \mathrm{L}$ ) ao longo do segundo bloco de 2 min, especificamente. Assim, obtivemos PCLs em três intervalos iguais: antes, durante e depois da microinjeção. Os efeitos das drogas sobre os PCLs foram atentamente acompanhados durante e após a microinjeção.

Conforme explicado adiante, na seção de experimentos preparatórios, nós padronizamos a duração dos efeitos de PILO e NIC sobre os PCLs de modo que ela 
coincidisse com a duração dos protocolos de estimulação indutores de plasticidade sináptica. De fato, obtivemos concentrações de PILO e NIC capazes de alterar os PCLs por 10-15 min, tempo suficiente para o registo de PCLs no bloco de 2 min pós-injeção e indução de plasticidade sináptica. Particularmente, em alguns sujeitos recebendo NIC os efeitos sobre os PCLs já se deflagravam durante a microinjeção (Fig. 11). Nestes casos, iniciamos a indução de plasticidade sináptica 2 min após o início dos efeitos sobre os PCLs sem que se completasse o período de $6 \mathrm{~min}$, respeitando-se a coincidência temporal almejada entre o efeito da droga e a estimulação indutora de plasticidade. Ao fim do registro de PCLs a agulha foi cuidadosamente retirada da cânula e os cabos de estimulação foram devolvidos às suas conexões originais para que pudéssemos induzir plasticidade sináptica.

\subsubsection{Indução de plasticidade sináptica e seu monitoramento}

O sistema de estimulação teve suas conexões restauradas para a aplicação dos trens de pulsos indutores de plasticidade sináptica, justamente durante os efeitos fugazes das drogas. Os protocolos de estimulação com trens de pulsos foram dois: estimulação em alta frequência (EAF, visando à indução de PLD) e baixa frequência (EBF, para indução de DLD). Conforme a Figura 8, EAF compôs-se de duas séries de 10 trens, separadas entre si por 10 min. Dentro de cada série, os trens foram espaçados entre si por $10 \mathrm{~s}$. Cada trem conteve 50 pulsos a $250 \mathrm{~Hz}$, totalizando $200 \mathrm{~ms}$ por trem ${ }^{150,265,266}$. No todo, EAF durou $13 \mathrm{~min}$. Por sua vez, EBF consistiu num trem único de 1.200 pulsos a $2 \mathrm{~Hz}$, resultando numa sequência ininterrupta de $10 \min ^{149,150}$ (Fig. 8). Para controle das variáveis EAF e EBF, os gruposcontrole (Ctrl) simplesmente não receberam trens de pulsos por período equivalente às durações aproximadas de EAF e EBF (11 min). EAF e EBF foram configuradas por regulagens analógicas do estimulador $\mathrm{S} 88$, e a intensidade dos pulsos foi $60-70 \%$ da amplitude máxima da curva E/S, similarmente aos pulsos emitidos a 0,05 Hz durante a coleta de PPSCs basais.

Após aplicação de EAF ou EBF (ou nenhuma delas, nos grupos Ctrl), as configurações do estimulador S88 foram revertidas às originais da coleta de PPSCs basais, visando a uma nova coleta ininterrupta de PPSCs a cada 20 s, mas desta vez por 240 min (720 PPSCs no total). Durante o período passivo pós-EAF ou EBF, manteve-se vigilância sobre eventuais 
ruídos elétricos (com acompanhamento por um monitor de áudio, que recebia o sinal do eletrodo monopolar em paralelo), mudanças bruscas na temperatura do rato (com eventuais regulagens do placa aquecedora, se necessário), ou secreções atrapalhando suas vias áreas (com cuidadosa sucção por uma bombinha improvisada).

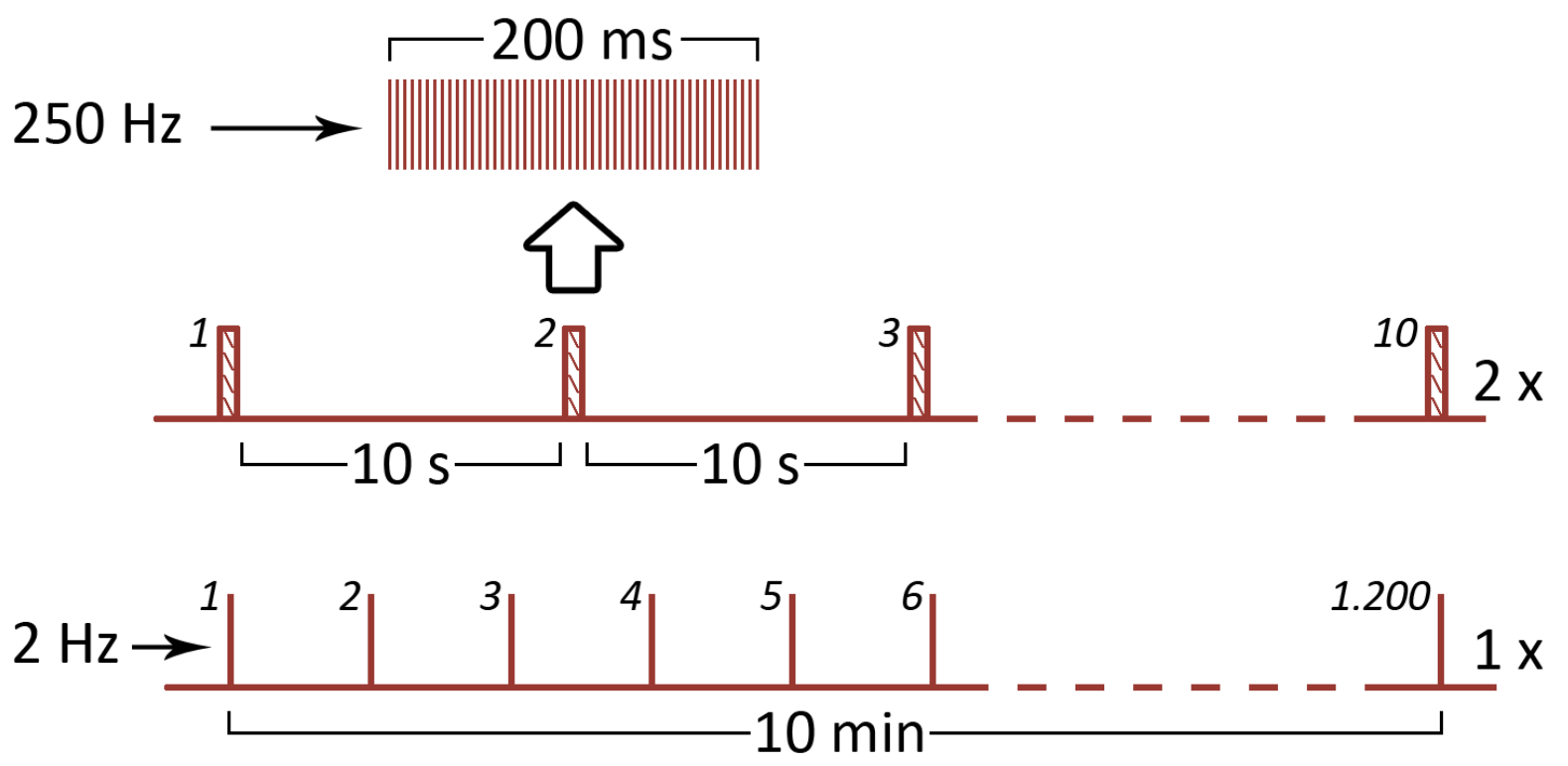

Figura 8. Trens de pulsos elétricos para indução de plasticidade sináptica. A EAF é representada pela parte superior da figura, mostrando uma sequência de 10 trens de pulsos separados entre si por $10 \mathrm{~s}$. Cada trem é composto por 50 pulsos a $250 \mathrm{~Hz}$, totalizando $200 \mathrm{~ms}$. A sequência de 10 trens é repetida uma vez, depois de $10 \mathrm{~min}$. No caso da EBF, na parte inferior da figura, o trem é único e formado por uma sequência ininterrupta de 1.200 pulsos a $2 \mathrm{~Hz}$, totalizando $10 \mathrm{~min}$. Na EAF, a duração de cada pulso monofásico foi $200 \mu \mathrm{s}$, e na EBF $100 \mu \mathrm{s}$. A ilustração tem fim didático e não respeita escalas precisas.

\subsubsection{Lesão eletrolítica, decapitação e histologia}

No fim do experimento, a sequência de pulsos foi interrompida e todos os cabos foram desligados do pré-amplificador. Então, um dos cabos relativos ao eletrodo bipolar foi conectado diretamente ao fio de aterramento (previamente ligado ao microparafuso preso ao crânio) para aplicação de uma corrente eletrolítica de $1 \mathrm{~mA}$ durante $1 \mathrm{~s}$ (carga de $1 \mathrm{mC}$ ), marcando-se a posição da extremidade do eletrodo bipolar com uma pequena lesão. 0 mesmo procedimento foi repetido para o eletrodo monopolar. Depois, cânula e eletrodos foram retirados para limpeza e reutilização (quando possível). Após dose adicional de uretana em solução salina, o rato foi decapitado com guilhotina apropriada (Insight, Brasil) e 
teve seu encéfalo removido para pós-fixação ao formaldeído $10 \%$ (em $\mathrm{NaCl}$ 0,9\%) por $24 \mathrm{~h}$ sob $4{ }^{\circ} \mathrm{C}$ (refrigerador comum). Os encéfalos foram, então, mergulhados em solução de sacarose $20 \%$, também sob $4{ }^{\circ} \mathrm{C}$, durante $48 \mathrm{~h}$, para proteção tecidual necessária ao fatiamento em criostato (Carl Zeiss, EUA).

Antes do fatiamento ao criostato, fizemos congelamento rápido dos encéfalos, mergulhando-os por $1 \mathrm{~min}$ em isopentano absoluto envolvido por gelo seco. Neste momento, ou o encéfalo era diretamente encaminhado ao criostato $\left(-20^{\circ} \mathrm{C}\right)$, ou armazenado em congelador $\left(-70{ }^{\circ} \mathrm{C}\right)$, dependendo da disponibilidade do criostato ou agenda de experimentos. Uma vez no criostato, a base do encéfalo foi aderida à resina Tissue-Tek (Sakura, EUA), antes da obtenção de fatias com $30 \mu \mathrm{m}$ de espessura. As fatias foram montadas sobre lâminas gelatinizadas com acompanhamento visual do atlas ${ }^{119}$ e deixadas em repouso à temperatura ambiente para secagem, de um dia para o outro. As lâminas foram, então, submetidas à coloração de Nissl, numa sequência de imersões para hidratação (clorofórmio absoluto, etanol absoluto, etanol 70\% e água destilada, 5 min cada), coloração (violeta de cresil, 30 s) e desidratação/limpeza (etanol 70\%, etanol absoluto e xilol, 5 min cada). As lamínulas foram coladas com resina histológica e deixadas em repouso por pelo menos 2 dias. Obtivemos as fotomicrografias digitais ao microscópio ótico (AxioPhot, Carl Zeiss, EUA) e arquivamos as lâminas em caixas plásticas apropriadas.

\subsubsection{Grupos experimentais}

Todo o método descrito até aqui diz respeito aos três experimentos de plasticidade sináptica, que são os principais. Especificaremos, agora, o planejamento de variáveis e a nomenclatura que atribuímos aos grupos que resultaram da combinação destas variáveis. No experimento 1 , testamos a modulação colinérgica sobre a PLD pré-frontal induzida a partir do Tmd. Para isto, aplicamos EAF durante os efeitos de PILO, NIC, ou VEIC. Assim, os ratos foram divididos nos grupos PILO-EAF $(n=8)$, NIC-EAF $(n=7)$, e VEIC-EAF $(n=8)$. No experimento 2, testamos a modulação colinérgica sobre a indução de DLD. Para isto, aplicamos EBF durante os efeitos de PILO, NIC, ou VEIC, o que implicou nos grupos PILO-EBF $(n=8)$, NIC-EBF $(n=8)$, e VEIC-EBF $(n=8)$. No experimento 3 , avaliamos a modulação 
colinérgica sobre os PPSCs basais sem aplicação de quaisquer trens de pulsos, para controle (Ctrl) quanto às variáveis EAF e EBF. Para tanto, no período correspondente à EAF ou EBF (11 min) nós simplesmente continuamos a registrar PCLs, sem emissão de pulsos. Isto implicou nos grupos PILO-Ctrl $(n=8)$, NIC-Ctrl $(n=8)$, e VEIC-Ctrl $(n=8)$. Linhas temporais ilustrando os grupos experimentais estão nas Figuras 12, 13 e 14, acompanhando os respectivos dados.

\subsection{Análise dos dados}

\subsubsection{Atividade oscilatória}

O registro de PCLs permitiu o acompanhamento em tempo real da latência e magnitude dos efeitos das drogas enquanto elas eram injetadas. Porém, mais importante que isto foi nossa análise a posteriori dos PCLs, que revelou com rigor os detalhes das mudanças. A análise dos PCLs requereu um pré-processamento dos dados individuais de cada sujeito, preparatório para aplicação à programação em MATLAB (MATrix LABoratory, MathWorks, EUA). Tal programação envolveu diferentes funções, sendo algumas já embutidas no próprio MATLAB e outras escritas manualmente. O sinal originalmente contínuo dos PCLs (amostrados em 200 pontos por segundo) foi dividido em oito janelas de Hann com duração de 1,25 s (625 pontos) em cada janela. O cálculo de janelas de Hann é um procedimento comumente aplicado sobre sinais oscilatórios imperfeitos, como os sinais biológicos, pois padroniza os valores extremos (começo e fim de cada janela) em zero. Esta padronização evita um tipo de distorção à análise de frequências conhecidas como fuga, ou vazamento (leakage). A perda de informações nas bordas das janelas de Hann foi feita pela sobreposição de $50 \%$ entre uma janela e outra, ao longo da sequência temporal. Como última etapa, calculamos a densidade espectral de Welch sobre cada janela de Hann, e obtivemos as médias de tais densidades em blocos de oito janelas, isto é, $10 \mathrm{~s}$. Portanto, a saída dos resultados foi expressada em épocas de $10 \mathrm{~s}$ do eletrencefalograma plotadas sobre o eixo de tempo nas abscissas, de modo que pudemos testar estatisticamente os resultados sob análise de variância (ANOVA) de duas vias com medidas repetidas (SigmaStat, Systat, 
EUA). Na ANOVA, a variável independente foi a substância injetada (PILO, NIC, ou VEIC, somando-se os ratos que receberam EAF, EBF, ou Ctrl) e as medidas repetidas foram os blocos de $10 \mathrm{~s}$ ao longo do período de $6 \mathrm{~min}$. A ANOVA foi seguida pelo teste post-hoc de Newman-Keuls, indicando as diferenças significativas entre os grandes agrupamentos PILO, NIC, ou VEIC conforme os blocos de $10 \mathrm{~s}$. 0 critério de significância estatística foi $P<0,05$.

Delimitamos quatro bandas de frequências para a análise de densidade espectral de Welch: delta $(0,5-4 \mathrm{~Hz})$, teta $(4-12 \mathrm{~Hz})$, beta $(12-30 \mathrm{~Hz})$ e gama $(30-80 \mathrm{~Hz})$. Dentro da banda gama, em particular, a faixa entre 58 e $62 \mathrm{~Hz}$ foi subtraída para remoção do ruído de $\sim 60 \mathrm{~Hz}$, inerente à corrente alternada predial. Embora a proteção exercida pela malha de Faraday tenha reduzido drasticamente tal ruído, sua eliminação não foi total. Assim, mesmo em baixa potência, o ruído de $\sim 60 \mathrm{~Hz}$ poderia contaminar os resultados referentes à banda gama, caso não fosse removido a posteriori.

De maneira geral, as frequências delta têm potência elevada durante estados de inconsciência, como anestesia e sono de ondas lentas, além de ocorrerem sob episódios de repouso comportamental durante a vigília ${ }^{41}$. Frequências teta são associadas a estados mais ativos, como os que acompanham a exploração ambiental e o sono paradoxal, sendo especialmente bem estudadas no hipocampo ${ }^{274,275}$. Por fim, as bandas beta e gama, também encontradas no sono paradoxal, são relacionadas a estados de máxima atenção quando ocorrem durante a vigília ${ }^{10,54}$. O padrão de beta-gama usado por nós respeita tendências recentes em que frequências de $\sim 20-90 \mathrm{~Hz}$ são consideradas basais à coerência talamocortical sob demanda atentiva e sensorial ${ }^{243}$.

\subsubsection{Plasticidade sináptica}

Tendo em vista que os PPSCs foram evocados a cada $20 \mathrm{~s}$, a coleta de PPSCs basais (30 min) rendeu 90 PPSCs e o monitoramento pós-EAF, EBF, ou Ctrl (240 min), rendeu 720 PPSCs. Para a análise de plasticidade sináptica, medimos a amplitude de todos os PPSCs utilizando macros automáticos, configurados a partir dos mesmos softwares (Scope ou LabChart, ADInstruments, Austrália) usados para coleta e armazenamento dos dados. Basicamente, a construção dos macros consistiu na delimitação de uma janela temporal em 
milissegundos (eixo de abscissas) que abarcasse de maneira padronizada os picos positivo e negativo dos PPSCs (Fig. 7). Independentemente da ligeira variação entre PPSCs, estes macros padronizados forneceram os valores numéricos referentes ao ponto mais positivo e mais negativo de cada PPSC no eixo de ordenadas, em centenas de microvolts. Assim, quando aplicados em sequência automática pelos softwares, os macros produziram uma tabela de valores em microvolts, que pôde ser inserida em planilha comum (Microsoft Excel, EUA). Utilizando as ferramentas da planilha, calculamos a amplitude de cada PPSC, ou seja, a diferença entre seus valores extremos no eixo de microvolts.

Então, agrupamos as amplitudes em blocos de $10 \mathrm{~min}$, de modo que cada bloco passou a ser representado pela amplitude média de seus 30 PPSCs. Tais amplitudes médias foram calculadas como porcentagens em relação à amplitude média da linha de base inteira, previamente normalizada como 100\%. Aumentos da amplitude (por exemplo, 130\%) posteriores à coleta de PPSCs basais foram interpretados como PLD, caso fossem consistentes e duradouros. Opostamente, diminuições duradouras (por exemplo, 80\%) foram interpretadas como DLD. Os dados foram submetidos à ANOVA de duas vias com medidas repetidas. As variáveis independentes foram os grupos de ratos e as medidas repetidas foram os blocos de $10 \mathrm{~min}$. A ANOVA foi seguida pelo teste post-hoc de NewmanKeuls e o critério de significância estatística foi $P<0,05$.

\subsubsection{Correlações lineares}

Com objetivo de testar se a magnitude dos efeitos de PILO ou NIC sobre os PCLs foi correlacionada com a magnitude das mudanças tardias nos PPSCs, reunimos os dados de todos os ratos nos três grandes grupos EAF, EBF, e Ctrl, independentemente da substância injetada no VL. Em seguida, calculamos a correlação linear de Pearson entre a potência relativa em cada banda de frequências (delta, teta, beta e gama) e a amplitude média nos blocos de 10 min do monitoramento pós-EAF, EBF, ou Ctrl. Para isto, utilizamos MATLAB para automatizar a concatenação entre as quatro bandas e os 24 blocos de 10 min do monitoramento de PPSCs. Definimos o critério de significância estatística em $P<0,05$. 


\subsection{Padronização das coordenadas estereotáxicas de estimulação}

Como mencionado na justificativa, este Doutorado faz parte de um conjunto de projetos envolvendo plasticidade sináptica no CPFm, porém com estimulação do CA1 hipocampal ${ }^{261,266,267}$. Assim, as coordenadas estereotáxicas para o implante do eletrodo de registro no CPFm já haviam sido adaptadas aos ratos disponíveis em nosso Campus. Considerando-se a não-especificidade laminar inerente ao registro de campo no CPFm, bem como o fato de CA1 e Tmd compartilharem a área pré-límbica do CPFm como um dos alvos de suas projeções ${ }^{270,271}$, nós aproveitamos a padronização já adquirida pelo laboratório quanto ao posicionamento do eletrodo de registro. Previmos que este usufruto poderia ser importante, uma vez que viríamos a investir esforço na padronização de coordenadas novas, cuja dificuldade de acesso desconhecíamos.

De fato, a primeira etapa deste Doutorado demandou alguns meses de alternância entre as experimentações eletrofisiológicas (sem compromisso, ainda, com uma coleta de dados padronizada em plasticidade sináptica) e preparações histológicas (observando-se a variação de posicionamento do eletrodo de estimulação). Como ponto de partida, nossa estratégia foi alvejar porções intermediárias do Tmd nas dimensões ântero-posterior e médio-lateral, sem seletividade quanto às suas subdivisões medial, central e lateral ${ }^{129}$. No progresso das cirurgias-teste, notamos um aumento da regularidade de obtenção dos PPSCs (até uma eficiência máxima de $70 \%$ dos sujeitos) ao deslocarmos o eletrodo de estimulação em direção ao bregma e à linha média, ou seja, buscando-se a porção rostromedial do Tmd. Esta busca pelo ponto ideal de estimulação rendeu uma varredura de $-2,40$ até $-1,90 \mathrm{~mm}$ no eixo ântero-posterior e de 1,00 até $0,35 \mathrm{~mm}$ no eixo médio-lateral, conforme nossas coordenadas. A padronização das coordenadas de estimulação guiada por otimização de PPSCs acabou sendo coerente com o mapeamento anatômico atualizado por Hoover e Vertes $(2007)^{118}$, publicado pouco mais de um ano antes do início de nosso trabalho. Afinal, como comentado em nossa revisão da literatura, os autores mostraram que a porção rostromedial do Tmd concentra a maior a quantidade de células de projeção ao CPFm, especialmente suas áreas ventrais PrL e IL (Fig. 1). 


\subsection{Padronização da concentração das drogas conforme a duração de seus efeitos}

O objetivo de nossos experimentos principais foi o de induzir plasticidade sináptica justamente durante o efeito dos agonistas colinérgicos sobre os PCLs. Uma vez que EAF e EBF já tivessem sido aplicadas, seria interessante que tal efeito se desvanecesse em não mais que alguns minutos. Assim, eventuais mudanças de longo prazo (horas) nos PPSCs poderiam ser interpretadas como resultado tardio de uma interação temporalmente restrita entre a ativação colinérgica global do encéfalo e os mecanismos glutamatérgicos talamocorticais desencadeados pela EAF e EBF.

Considerando-se que viríamos a injetar PILO e NIC no VL concomitantemente ao registro de PCLs, procuramos quais concentrações das drogas produziriam efeitos em PCLs com durações próximas às de EAF e EBF. A necessidade da padronização levou-nos a experimentos de concentração-efeito para PILO e NIC na via intraventricular. Um experimento prévio de nosso laboratório ${ }^{261}$ havia indicado que $1 \mu \mathrm{L}$ de líquido cerebrospinal artificial com PILO dissolvida a $40 \mathrm{nmol} / \mu \mathrm{L}$ (concentração sub-epiléptica) é suficiente para potencializar as oscilações rápidas (teta, beta e gama) por 10-15 min, tempo suficiente para EAF e EBF. Uma vez que o uso de PILO a $40 \mathrm{nmol} / \mu \mathrm{L}$ já havia sido incorporado à nossa rotina de injeções intraventriculares, não houve necessidade de repetir este experimento de concentração-efeito. Porém, um experimento similar para NIC não havia sido feito, uma vez que a droga ainda não tinha sido adquirida pelo laboratório antes deste Doutorado.

Assim, utilizando o mesmo anestésico e preparação cirúrgica dos experimentos principais, registramos PCLs corticais e talâmicos ininterruptamente por 120 min em uma amostra de oito animais. Nestes casos, o sistema de estimulação não foi usado. Exatamente aos 30, 60 e 90 min aplicamos a injeção intraventricular de NIC em uma de três concentrações candidatas: 160, 320 e $640 \mathrm{nmol} / \mu \mathrm{L}$, escolhidas após levantamento paramétrico de estudos utilizando injeção intraventricular de $\mathrm{NIC}^{276-279}$. A velocidade da injeção foi a mesma dos experimentos principais ( $1 \mu \mathrm{L}$ ao longo de $2 \mathrm{~min}$ ) e a sequência das diferentes concentrações foi aleatória entre os sujeitos. Após análise em MATLAB, empregando-se as mesmas funções e procedimentos de pré-processamento descritos anteriormente, foi determinada a latência entre o início da microinjeção e o início dos efeitos de NIC sobre as quatro bandas de frequências (especialmente beta-gama), bem 
como a duração de tais efeitos. Conforme os resultados expostos na Figura 8, a latência e duração dos efeitos de NIC sobre os PCLs são, de fato, dependentes da concentração injetada no VL. Em particular, a duração média dos efeitos de NIC a $320 \mathrm{nmol} / \mu \mathrm{L}$ foi a que mais se aproximou da duração da EAF e EBF. Portanto, esta concentração de NIC passou a ser usada nos experimentos principais de plasticidade sináptica.

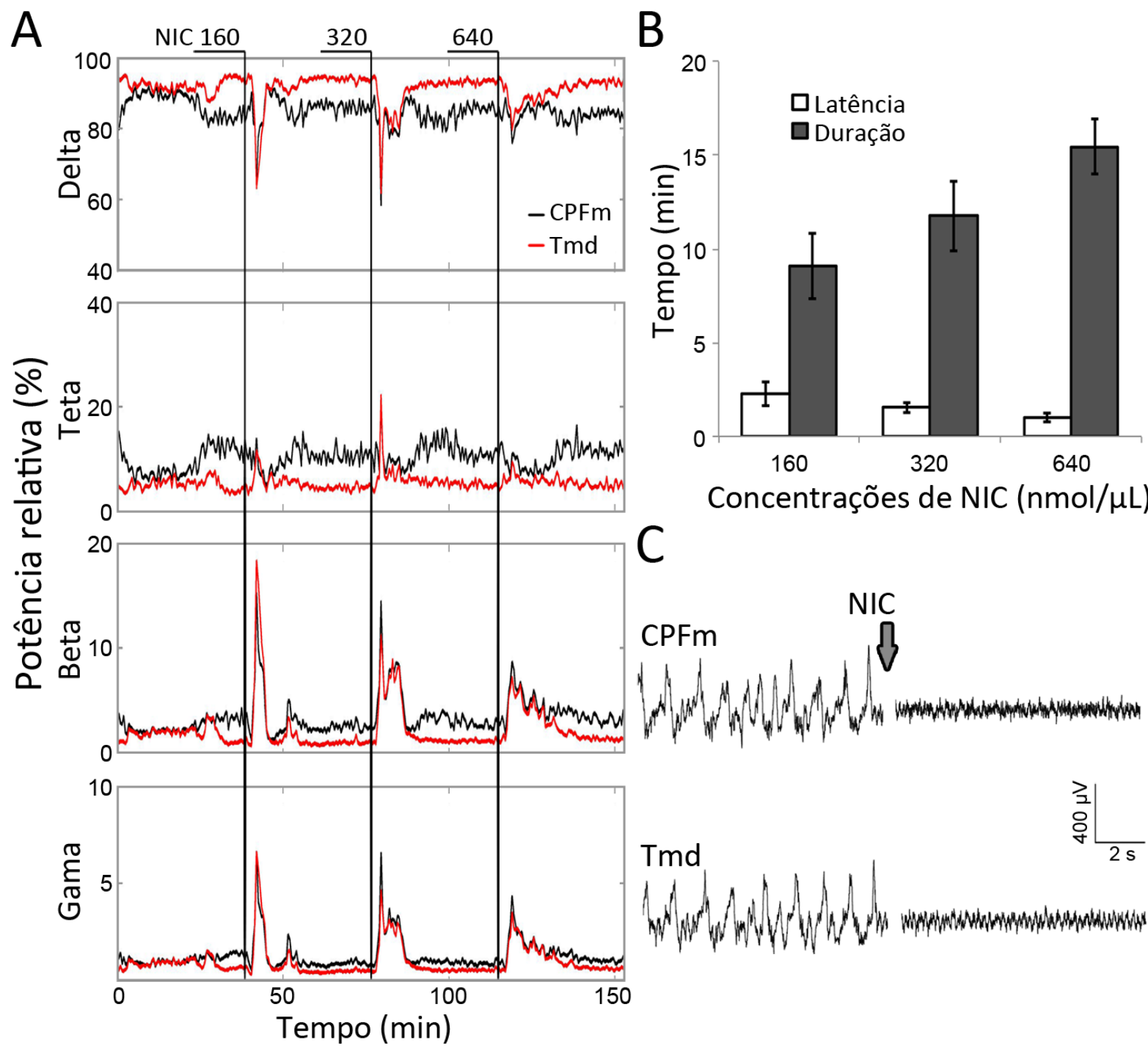

Figura 9. A latência e duração dos efeitos da NIC intraventricular sobre a atividade oscilatória prosencefálica dependem da concentração da droga. Diferentes concentrações de NIC (160, 320 e $640 \mathrm{nmol} / \mu \mathrm{L} ; 1 \mu \mathrm{L}$ intraventricular) foram injetadas enquanto PCLs eram registrados ininterruptamente durante 120 min para análise de potências nas bandas de frequências delta $(0,5-4 \mathrm{~Hz})$, teta $(4-12 \mathrm{~Hz})$, beta $(12-30 \mathrm{~Hz})$ e gama $(30-80$ $\mathrm{Hz}$ ). (A) PCLs contínuos registrados simultaneamente no CPFm e Tmd a partir de um sujeito representativo. (B) Análise de latência e duração das mudanças nos PCLs induzidas pela injeção intraventricular de diferentes concentrações de NIC numa amostra-piloto de oito ratos. A sequência de injeções em diferentes concentrações foi aleatória e os dados são mostrados como média \pm erro padrão. (C) PCLs representativos registrados no CPFm e Tmd antes e depois da microinjeção de NIC. Com este experimento preliminar, decidimos usar NIC a $320 \mathrm{nmol} / \mu \mathrm{L}$ para induzir um efeito temporário ( $10-15 \mathrm{~min}$ ) que coincidisse com a duração de EAF e EBF. 
Através da descrição das padronizações preparatórias, procuramos esclarecer nossos procedimentos quanto à definição de um sítio de estimulação e controle dos efeitos das drogas sobre os PCLs. Todas estas informações poderão, a partir de agora, basear uma exposição mais objetiva dos resultados principais, com foco às figuras e suas legendas.

\subsection{Precisão dos implantes: refinamento conforme PPSCs e validação histológica}

Todos os animais incluídos nas análises principais tiveram o eletrodo de estimulação localizado na metade anterior do Tmd esquerdo, mais frequentemente em seus aspectos mediais. Por sua vez, o eletrodo de registro foi posicionado no CPFm esquerdo, preferencialmente no nível dorso-ventral da área PrL. Finalmente, a extremidade inferior da cânula foi majoritariamente localizada $1 \mathrm{~mm}$ acima do VL direito, de modo que somente a agulha de microinjeção atingisse sua luz (Fig. 10A). Em poucos casos, a posição da cânula ficou ligeiramente deslocada no eixo meso-lateral, de modo que a injeção produziu lesões em tecidos que margeiam o VL (parede lateral do septo ou fímbria hipocampal, parede medial do núcleo caudado-putâmen, e corpo caloso). Estes casos foram mantidos nas análises finais contanto que os efeitos de PILO e NIC tivessem se manifestado nos PCLs. Excluímos os casos em que o conteúdo injetado ficou circunscrito aos tecidos vizinhos por erro grosseiro de posicionamento.

Conforme explicado na seção de métodos, emitimos pulsos a cada $20 \mathrm{~s}$ enquanto o eletrodo de estimulação era baixado em direção ao Tmd em passos de $200 \mu \mathrm{m}$, estando o eletrodo de registro já posicionado no CPFm. Por este procedimento, encontramos um consistente perfil dorso-ventral de PPSCs evocados a partir do trajeto percorrido pelo eletrodo bipolar (Fig. 10B). Mais especificamente, aproximadamente 3,00 mm abaixo da dura-máter (ou seja, na altura correspondente ao corpo caloso), evocamos um PPSC com pico negativo em $\sim 9,00$ ms de latência. O mesmo padrão de PPSC continuava a ser eliciado conforme o eletrodo bipolar atravessava o hipocampo. A partir de $\sim 4,2-4,4 \mathrm{~mm}$ abaixo da dura-máter, os pulsos passavam a evocar PPSCs com latência do pico negativo gradualmente tendendo a $\sim 13,00 \mathrm{~ms}$ de latência. Finalmente, na continuidade da descida do eletrodo bipolar até não mais que 4,8-5,2 mm abaixo da superfície, o PPSC assumia mais claramente a 
aparência correspondente à estimulação do Tmd (Fig. 10B). Provavelmente, os PPSCs préfrontais evocados a partir da altura correspondente ao hipocampo são devidos à estimulação de fibras de passagem. Afinal, no nível ântero-posterior usado por nós para implante do eletrodo bipolar não há células hipocampais de projeção ao $\mathrm{CPFm}^{118}$. Dada a regularidade com que esta sequência de PPSCs foi evocada ao longo dos sujeitos, ela passou a ser usada como referência adicional ao refinamento da posição do eletrodo bipolar, sendo consolidada como parte do protocolo experimental.

Em aproximadamente metade dos sujeitos, os PPSCs evocados pelo Tmd apresentaram dois picos negativos distintos, que nós chamamos de N1 e N2 (Fig. 10C). Quando claramente detectado, N1 era um pico negativo de baixa amplitude $(108,20 \pm 9,32$ $\mu \mathrm{V})$ e latência curta $(6,85 \pm 0,15 \mathrm{~ms})$. Em alguns casos, na latência correspondente a N1, observamos apenas um desvio sutil, que não chegava a ter aparência de um pico negativo. Em outros casos, N1 não era sequer aparente. Diferentemente, o pico N2 foi caracterizado por amplitude maior $(270,00 \pm 17,10 \mu \mathrm{V})$ e latência também maior $(13,43 \pm 0,17 \mathrm{~ms})$, sendo consistentemente detectado em todos os sujeitos (Fig. 10C). Considerando-se as latências de $\mathrm{N} 1$ e N2, nossos PPSCs foram muito parecidos com os previamente descritos por Herry et al. e Herry e Garcia ${ }^{149,150}$, que utilizaram camundongos acordados. Aliás, os autores também relataram dificuldade em dissociar seu componente de latência curta ( $7 \mathrm{~ms}$ ) dependendo do sujeito, de modo que eles decidiram usar a amplitude do componente de latência longa ( 13 ms) em suas medidas de plasticidade sináptica. Nós adotamos um procedimento similar, e medimos a amplitude de N2 ao longo de nossos experimentos. A Tabela 1 mostra os parâmetros médios de N2 (amplitude e latência) obtidos a partir da coleta de PPSCS basais de todos os grupos dos experimentos principais. Como esperado, não há diferenças significativas entre os grupos, conforme ANOVA de uma via $(P>0,05)$. 
Tabela 1. Amplitude e latência do pico negativo N2 dos PPSCs basais.

\begin{tabular}{ccc}
\hline Grupos & Amplitude $(\boldsymbol{\mu} \mathrm{V})$ & Latência $(\mathrm{ms})$ \\
\hline PILO-EAF $(n=8)$ & $231,25 \pm 31,19$ & $13,22 \pm 0,31$ \\
NIC-EAF $(n=7)$ & $250,00 \pm 56,78$ & $14,57 \pm 0,39$ \\
VEIC-EAF $(n=8)$ & $335,00 \pm 83,00$ & $13,41 \pm 0,42$ \\
& & \\
PILO-EBF $(n=8)$ & $277,50 \pm 31,83$ & $13,22 \pm 0,51$ \\
NIC-EBF $(n=8)$ & $262,50 \pm 64,96$ & $13,65 \pm 0,68$ \\
VEIC-EBF $(n=8)$ & $341,25 \pm 63,82$ & $13,16 \pm 0,36$ \\
PILO-Ctrl $(n=8)$ & & \\
NIC-Ctrl $(n=8)$ & $255,00 \pm 31,40$ & $11,99 \pm 0,44$ \\
VEIC-Ctrl $(n=8)$ & $285,00 \pm 50,92$ & $14,01 \pm 0,60$ \\
\hline
\end{tabular}

Para a obtenção destes valores, promediamos os PPSCs basais de cada rato e, em seguida, calculamos a amplitude e latência média \pm erro padrão de cada grupo. Por fim, comparamos os grupos sob ANOVA de uma via e não encontramos diferenças significativas.

\subsection{Atividade oscilatória talâmica e cortical conforme a injeção das drogas}

Para todos os experimentos de plasticidade sináptica, nós analisamos os PCLs talâmicos e corticais 2 min antes, 2 min durante, e 2 min depois das microinjeções de PILO, NIC, ou VEIC. A Figura 11 mostra as mudanças das potências relativas nas bandas delta, teta, beta e gama registradas no Tmd e CPFm ao longo de épocas contínuas de 6 min. Note-se que PILO e NIC reduziram significativamente a potência em delta, com proporcionais aumentos nas oscilações teta, beta e gama. Particularmente, os efeitos de NIC sobre as quatro bandas de frequências tiveram latências menores do que os efeitos de PILO, já estando evidentes antes do fim da microinjeção. Além disto, NIC induziu uma potencialização maior das frequências beta e gama em comparação com PILO. Como esperado, a microinjeção do VEIC, por si só, não alterou o estado de ondas lentas promovido pelo anestésico (Fig. 11). Seguem os valores $F$ correspondentes aos efeitos de interação após ANOVA de duas vias com medidas repetidas. Delta no CPFm: $F_{(58,1653)}=5,18$; Teta no CPFm: $F_{(58,1653)}=4,04$; Beta no CPFm: $F_{(58,1653)}=8,93$; Gama no CPFm: $F_{(58,1653)}=13,88$; Delta no Tmd: $F_{(58,1653)}=6,04$; Teta no Tmd: $F_{(58,1653)}=5,54$; Beta no Tmd: $F_{(58,1653)}=13,64$; Gama no Tmd: $F_{(58,1653)}=16,58$. Todos os valores $P$ dos efeitos de interação foram $<0,001$, e as diferenciações post-hoc indicadas na Figura 11 foram obtidas pelo teste de Newman-Keuls. 


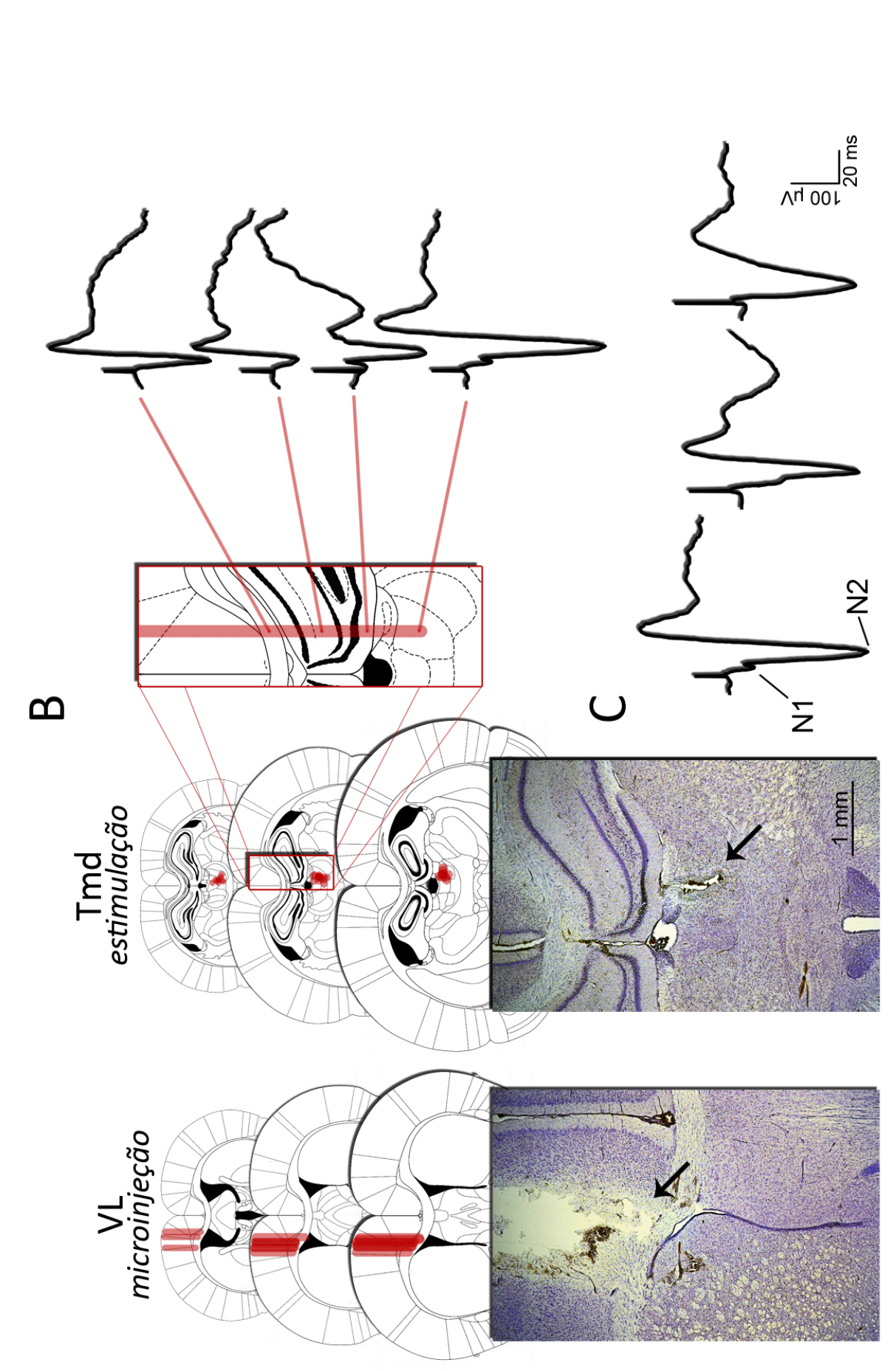

芹

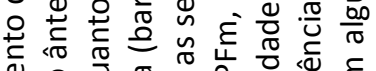

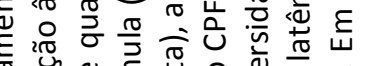

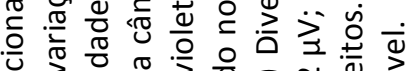
或

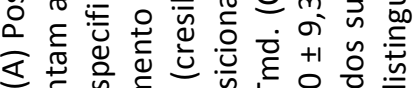

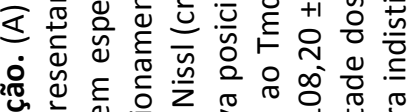
㟧 ध一兀 氙

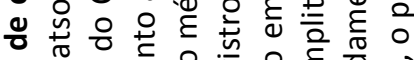

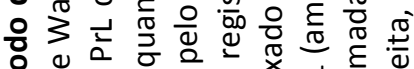

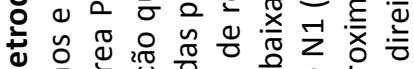

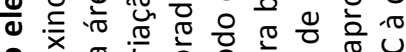
융 不 उٓ 壱

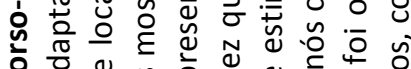

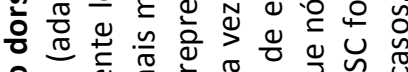

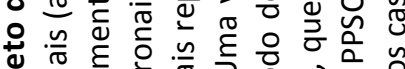

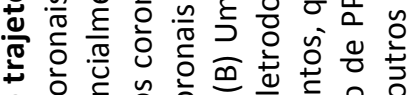

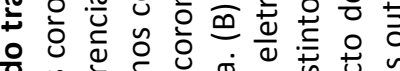

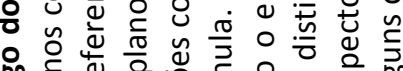

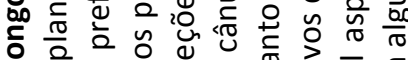

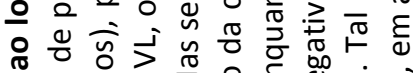

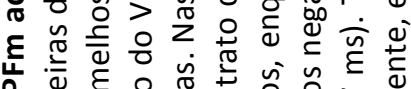

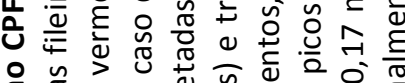

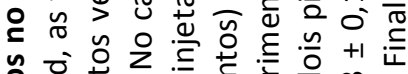

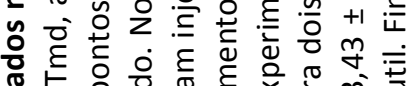

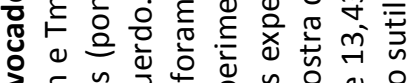

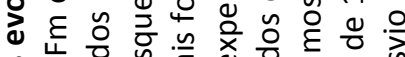
y

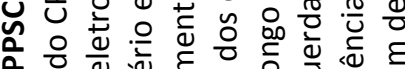

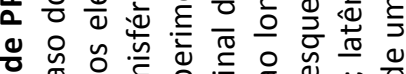
$\bar{E}$ 过

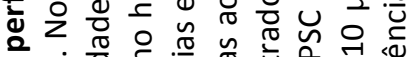

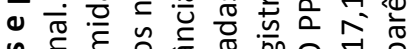

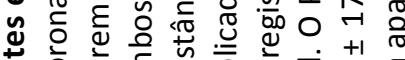

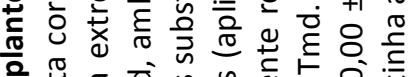

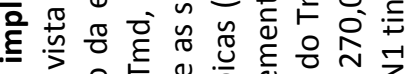

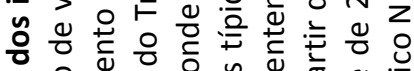

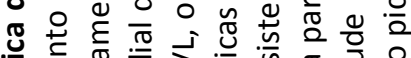

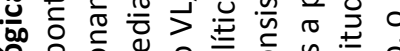
은 은 은

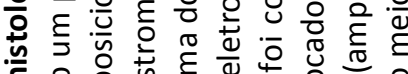

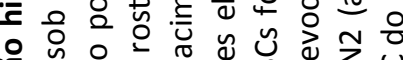
ri 0

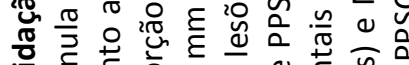

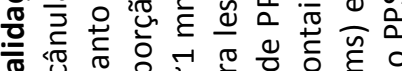

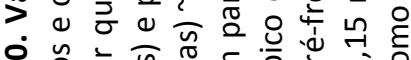

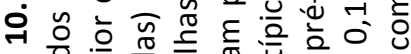

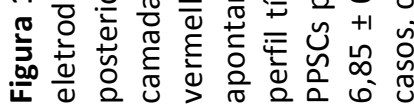




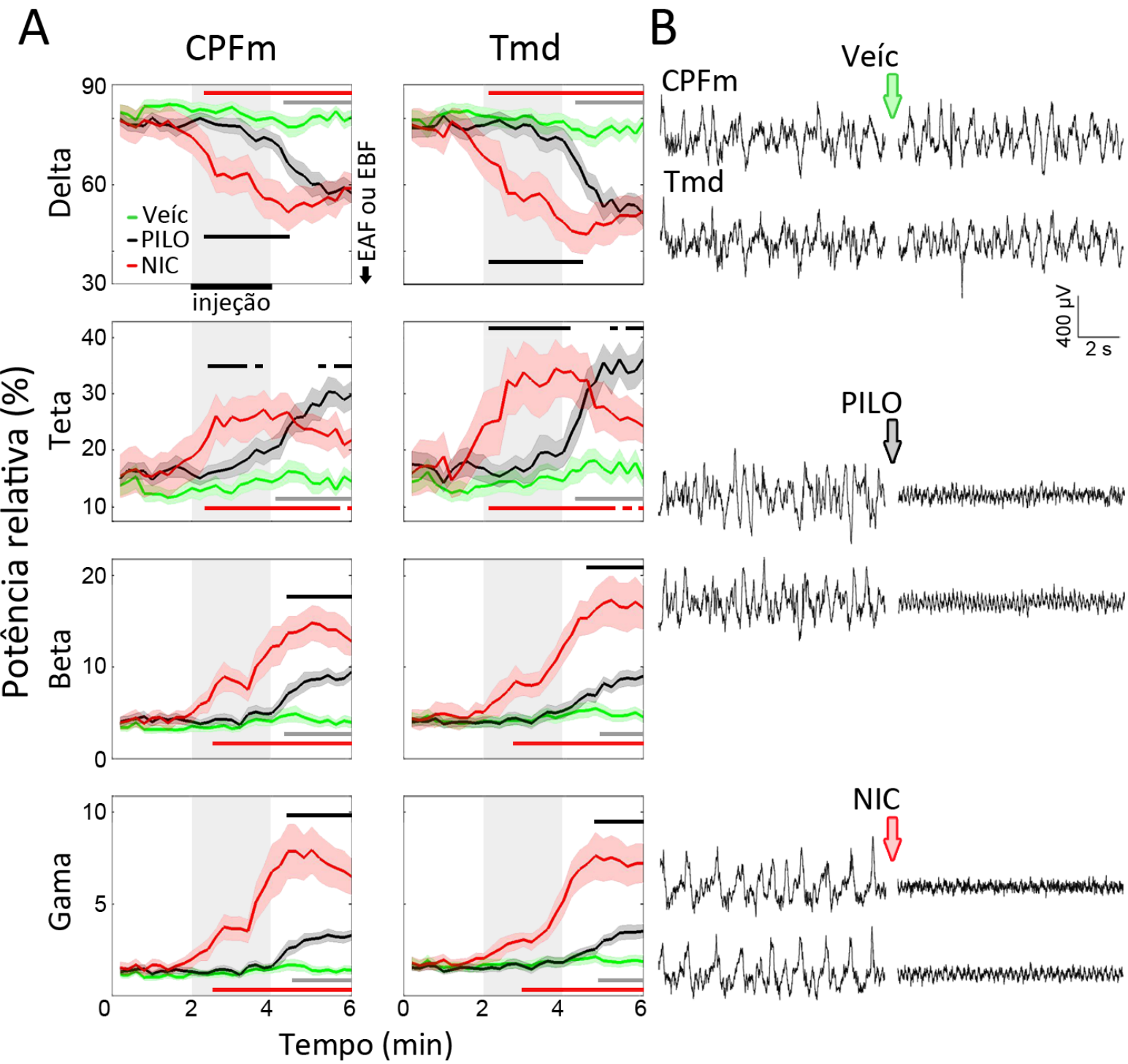

Figura 11. Bandas de frequências dos PCLs e suas potências relativas, comparando-se a atividade oscilatória cortical e talâmica antes, durante e depois da microinjeção de PILO, NIC ou VEIC. (A) Gráficos detalhando os efeitos de PILO e NIC sobre os PCLs ao longo dos 6 min de registro eletrográfico, mostrando decréscimo da potência em delta $(0,5-4 \mathrm{~Hz})$ e proporcional aumento da potência em oscilações rápidas, categorizadas como bandas teta $(4-12 \mathrm{~Hz})$, beta $(12-30 \mathrm{~Hz})$ e gama $(30-80 \mathrm{~Hz})$. As mudanças induzidas por NIC se manifestaram mais rapidamente do que as induzidas por PILO, com duração mais curta das mudanças em teta e potencialização mais forte das ondas beta e gama. Os dados dizem respeito à pré-ativação colinérgica dos experimentos de plasticidade sináptica, somando-se os ratos nos três grandes grupos VEIC, PILO e NIC independentemente de EAF, EBF ou Ctrl. As barras horizontais que acompanham cada gráfico representam diferenças significativas, indicadas por ANOVA de duas vias com medidas repetidas seguida pelo teste post-hoc de Newman-Keuls (barra cinza: VEIC x PILO; barra vermelha: VEIC x NIC; barra preta: PILO x NIC). Os dados são mostrados como média \pm erro padrão. (B) PCLs representativos registrados no CPFm e Tmd, mostrando épocas exemplares de $10 \mathrm{~s}$ contidas nos períodos pré e pós-microinjeção. 


\subsection{A ativação colinérgica prévia à EAF favoreceu uma PLD tardia no CPFm}

A aplicação da EAF no Tmd sob o contexto da anestesia, por si só, não induziu PLD no CPFm. Isto é o que podemos concluir a partir dos dados do grupo VEIC-EAF, que não mostram mudanças significativas nas amplitudes dos PPSCs por pelo menos $4 \mathrm{~h}$ (Fig. 12). Em contraste, quando a EAF foi aplicada durante os efeitos de PILO e NIC, houve uma PLD de manifestação tardia, que foi significativa a partir de $150 \mathrm{~min}$ de monitoramento pós-EAF (efeito de interação: $\left.F_{(46,460)}=1,71 ; P=0,003\right)$. Interessantemente, a PLD nos grupos PILOEAF e NIC-EAF evoluiu com cinéticas similares, de modo que em ambos os grupos a amplitude dos PPSCs chegou a 120-130\% em relação à média da linha de base (Fig. 12).

\subsection{A ativação colinérgica prévia à EBF suprimiu uma DLD estável no CPFm}

Nos animais em que a EBF foi aplicada sob as ondas lentas da anestesia (ou seja, após injeção do veículo), observamos uma DLD aproximadamente estável com duração de pelo menos $4 \mathrm{~h}$, com as amplitudes dos PPSCs mantendo-se em torno de 80-90\% do valor médio da linha de base (Fig. 13). Diferentemente, a DLD foi suprimida ao longo de todo o monitoramento de PPSCs quanto a EBF foi aplicada após PILO e NIC. Novamente, os efeitos pós-PILO e NIC tiveram cinéticas similares e converteram a DLD estável numa sutil PLD estável (Fig. 13; efeito de tratamento sem efeito de interação: $\left.F_{(2,21)}=6,72 ; P=0,006\right)$. 


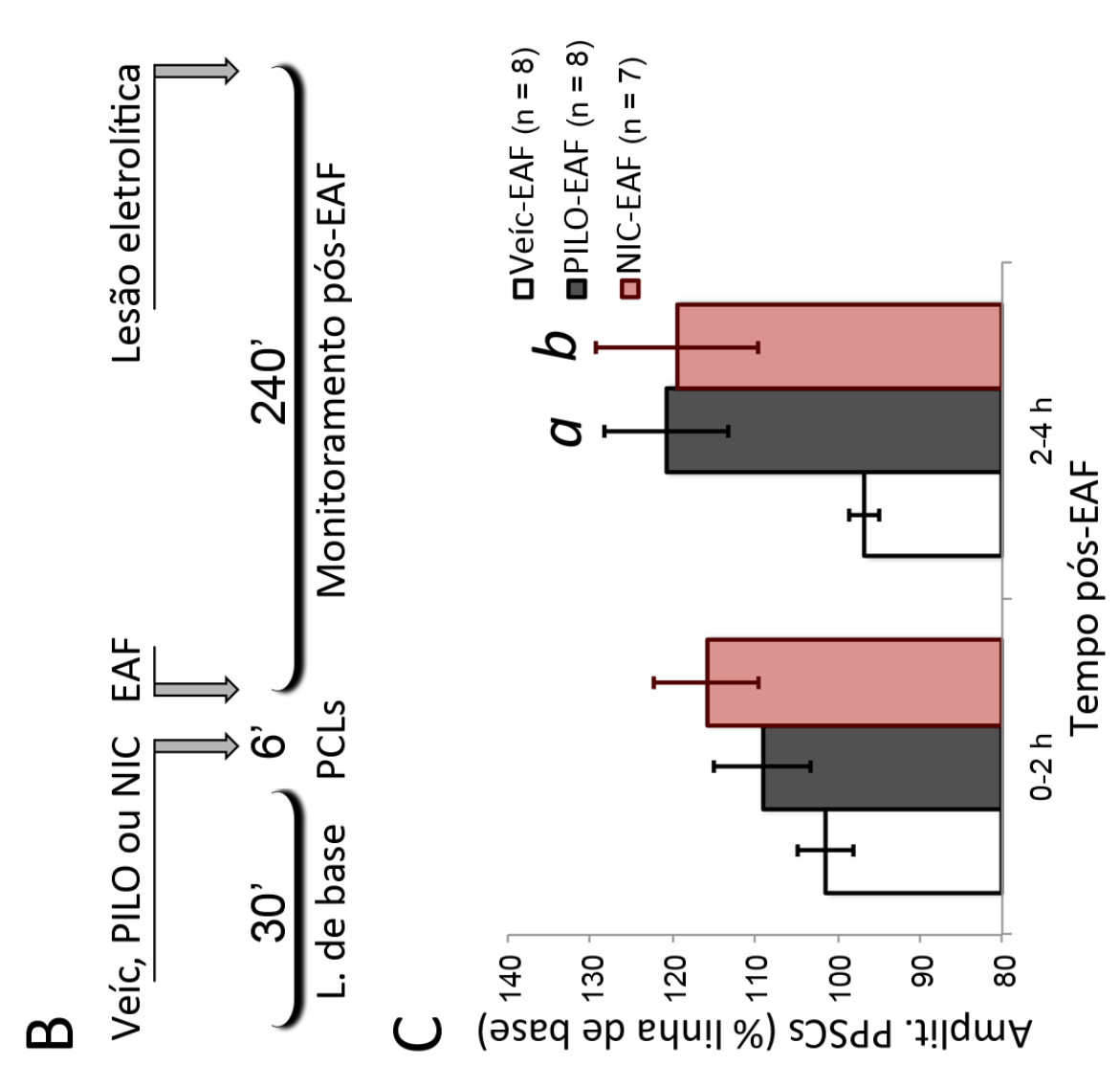

范

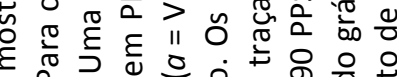

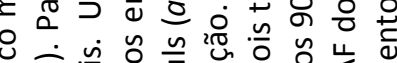

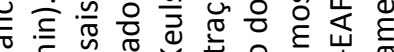
क力

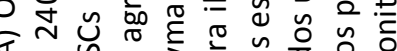

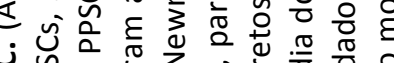

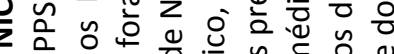
० O

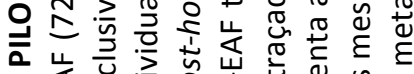
눈. นั

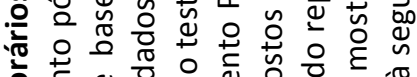
흔 ఖ

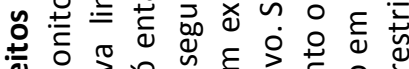

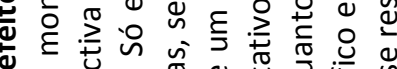

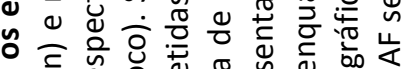

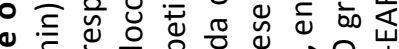
党 ह

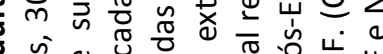
준

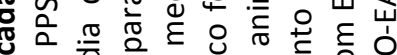

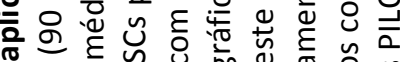

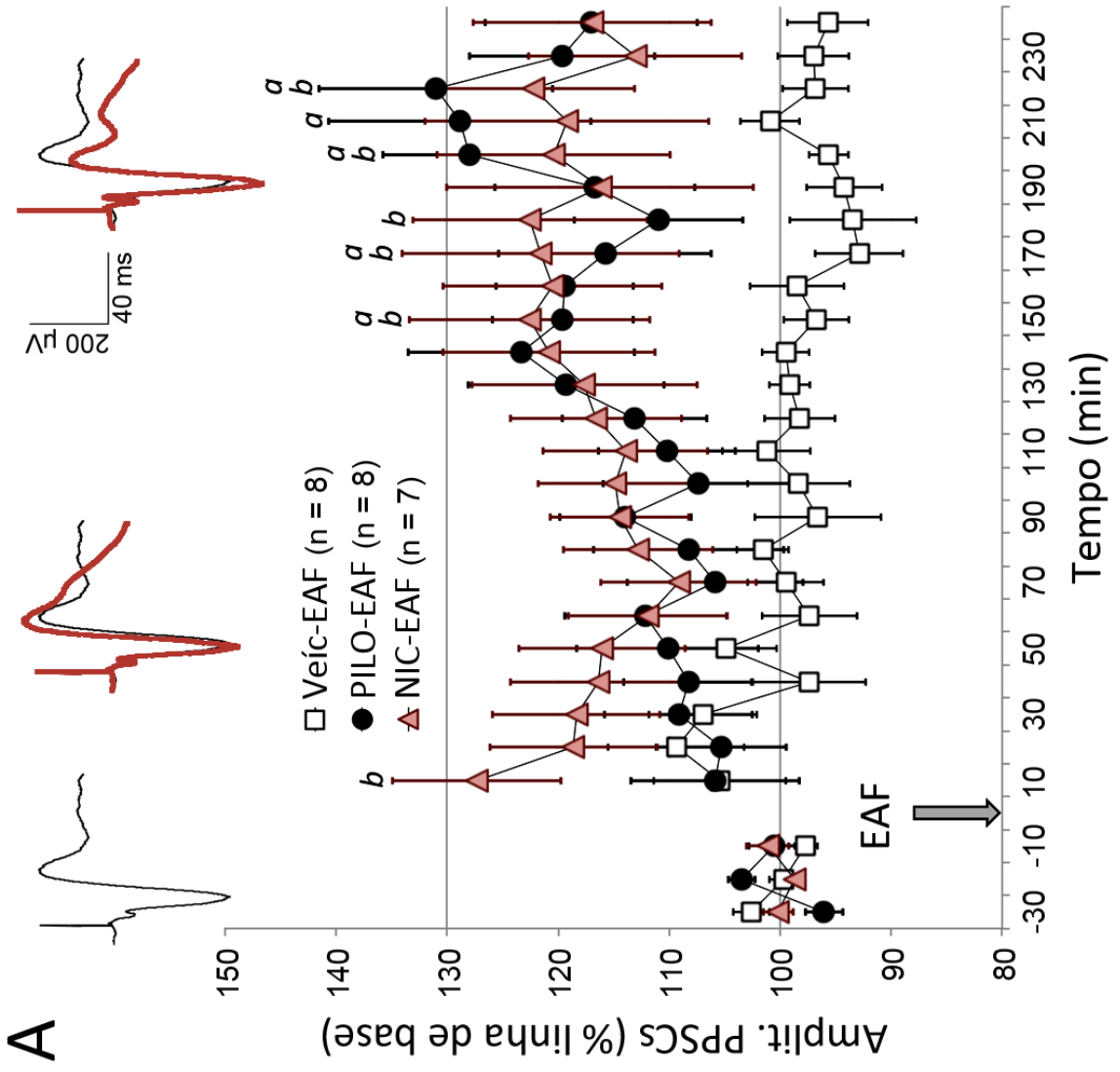

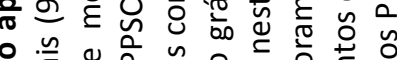

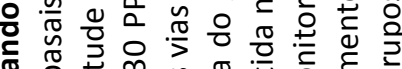

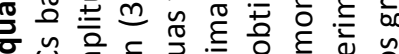
凹 동

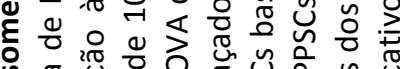

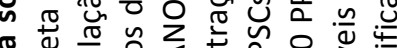

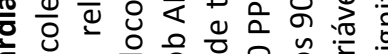

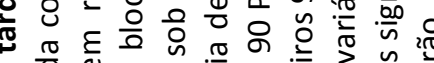

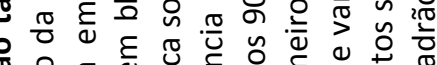
营

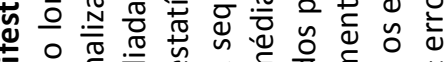
당

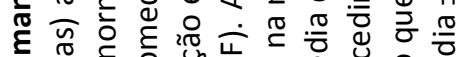

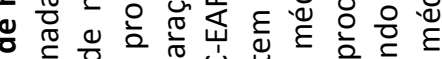

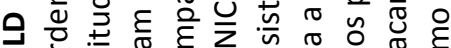

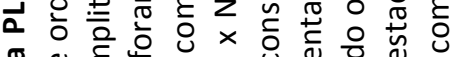

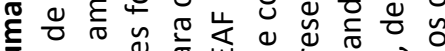
응

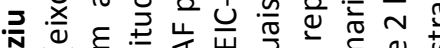

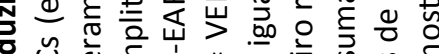

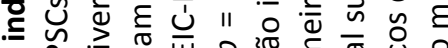
แล

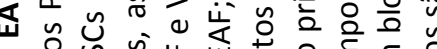

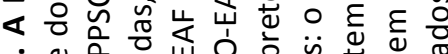

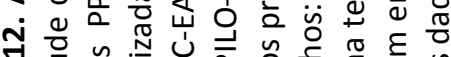
글

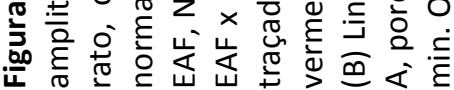




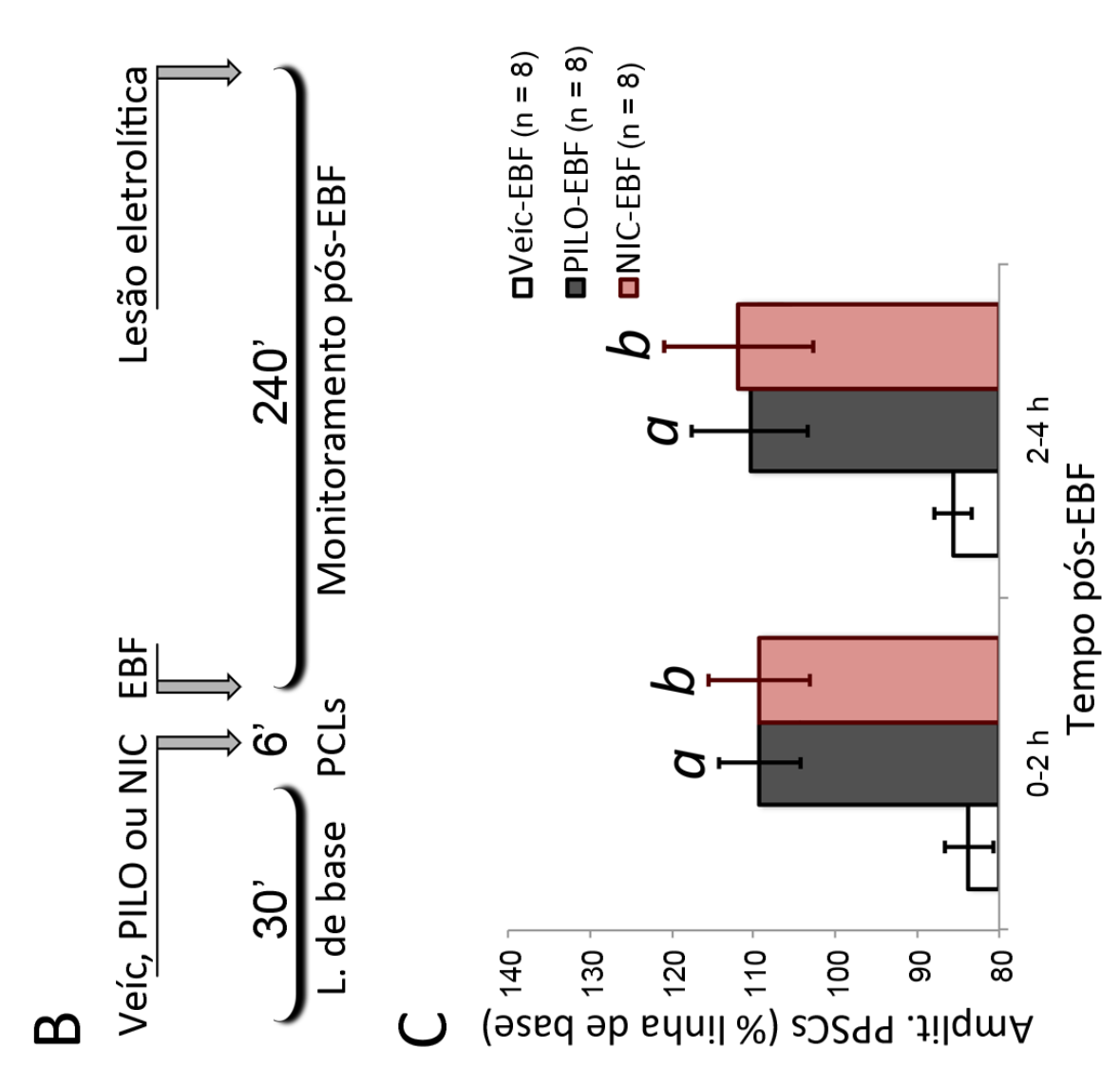

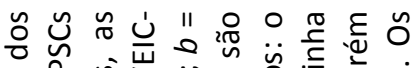

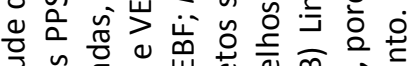

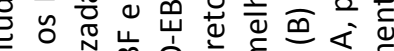

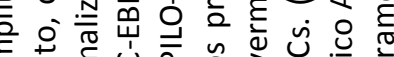
हाँ त

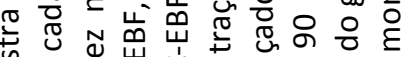

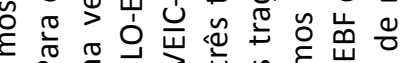

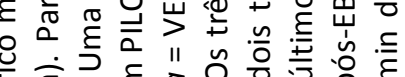

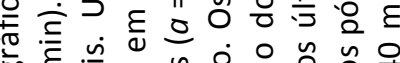

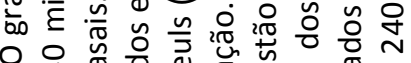

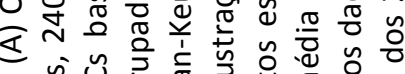

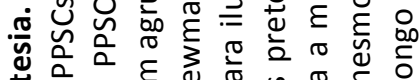

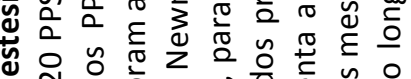
돈

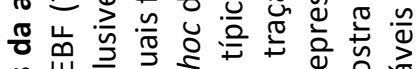

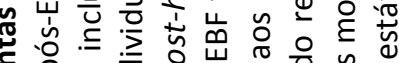

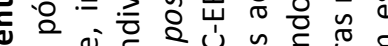

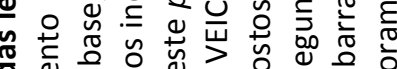
年

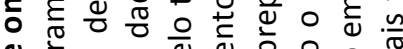
응

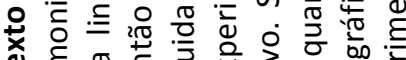

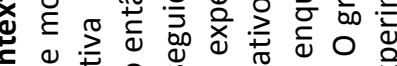

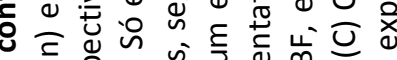
० है
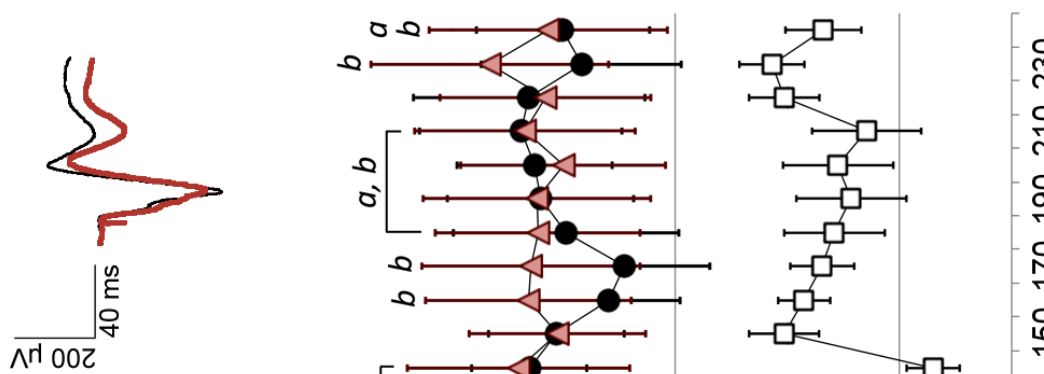

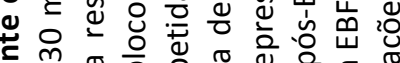

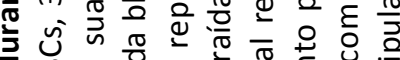

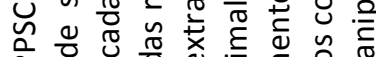

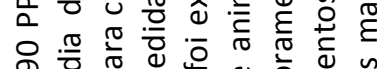

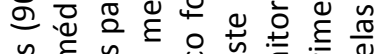
政记 윰 용 음 동

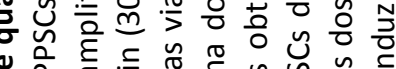

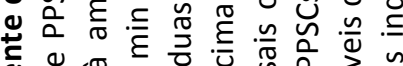

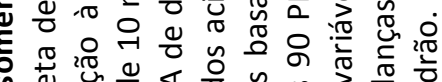

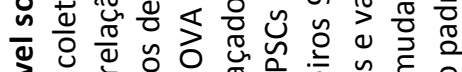

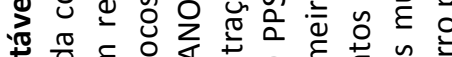

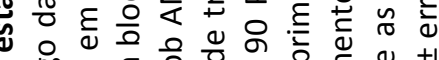

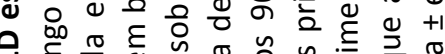
흐웡

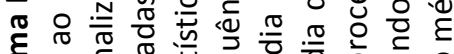

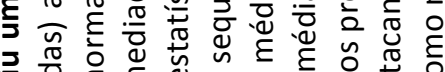
उ

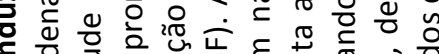

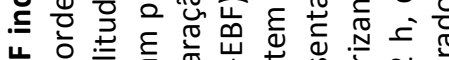

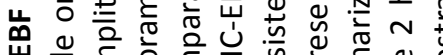

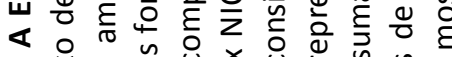

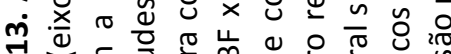
똔

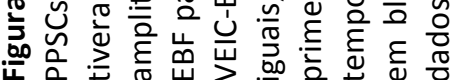




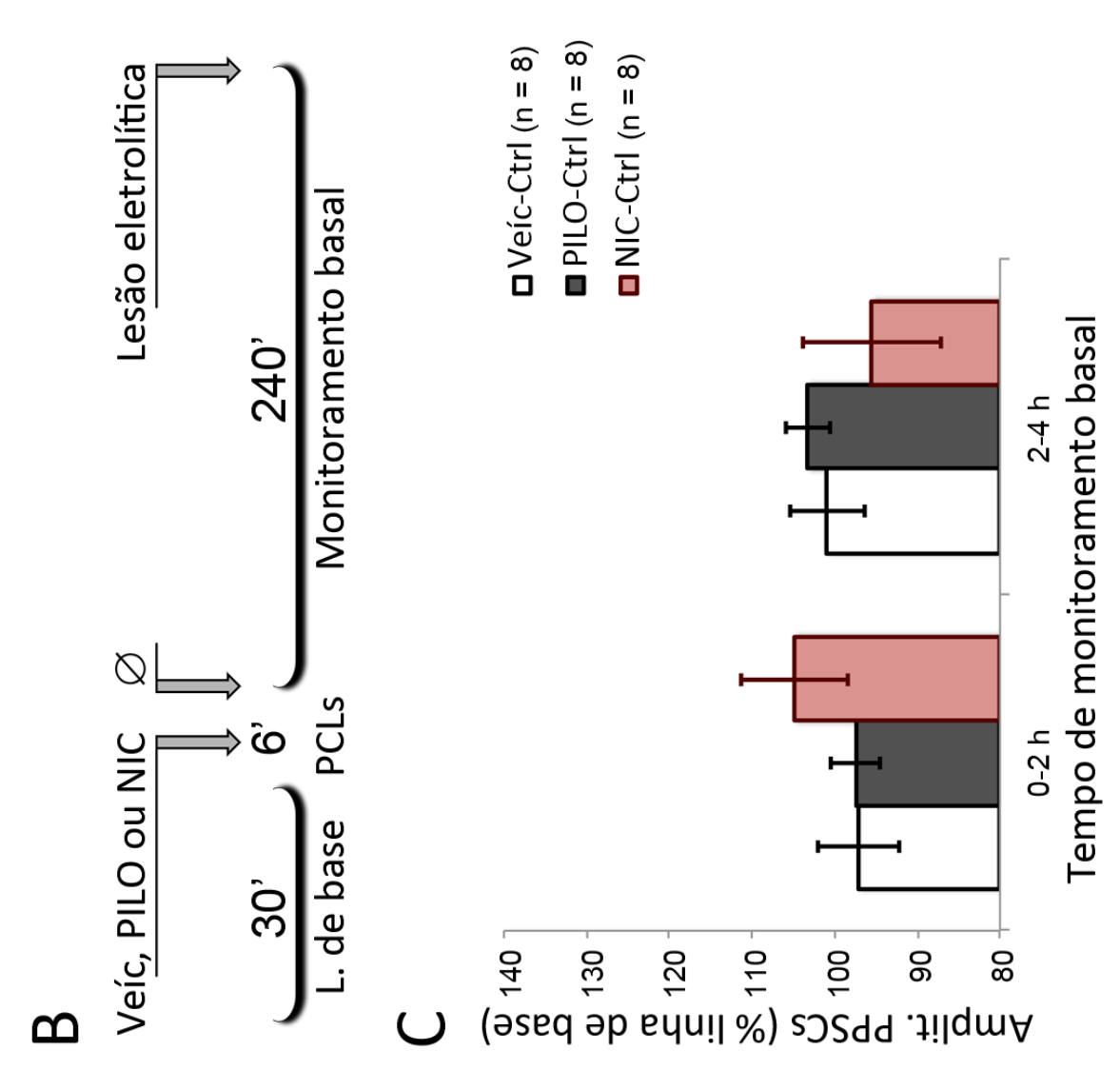

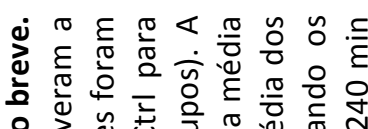

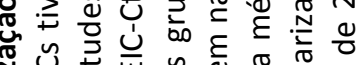

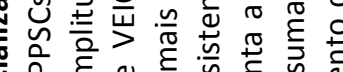

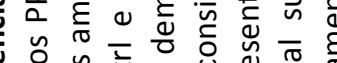
0.

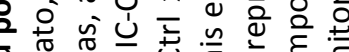

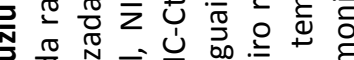

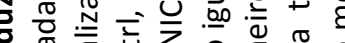
잉

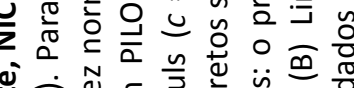

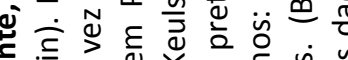

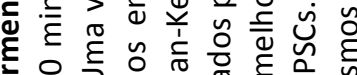

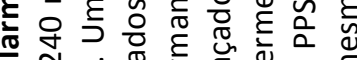
ᄀ

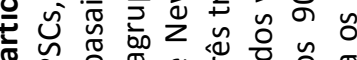
๘ บู่ 员

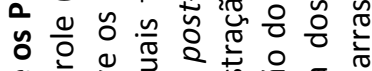

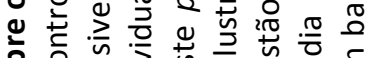

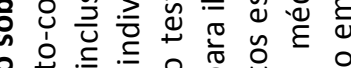

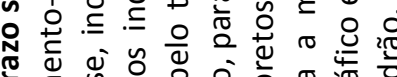

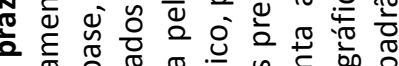

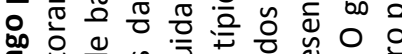
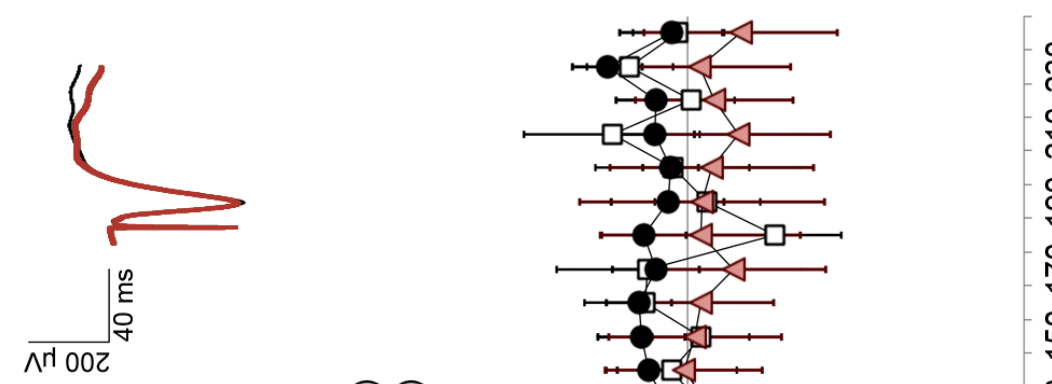

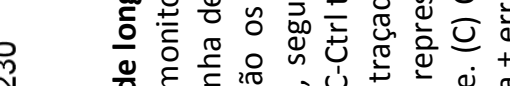

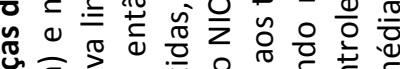

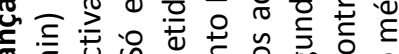

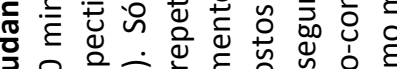

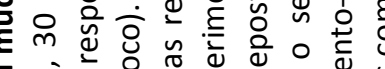
곤

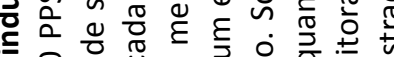

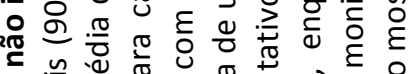

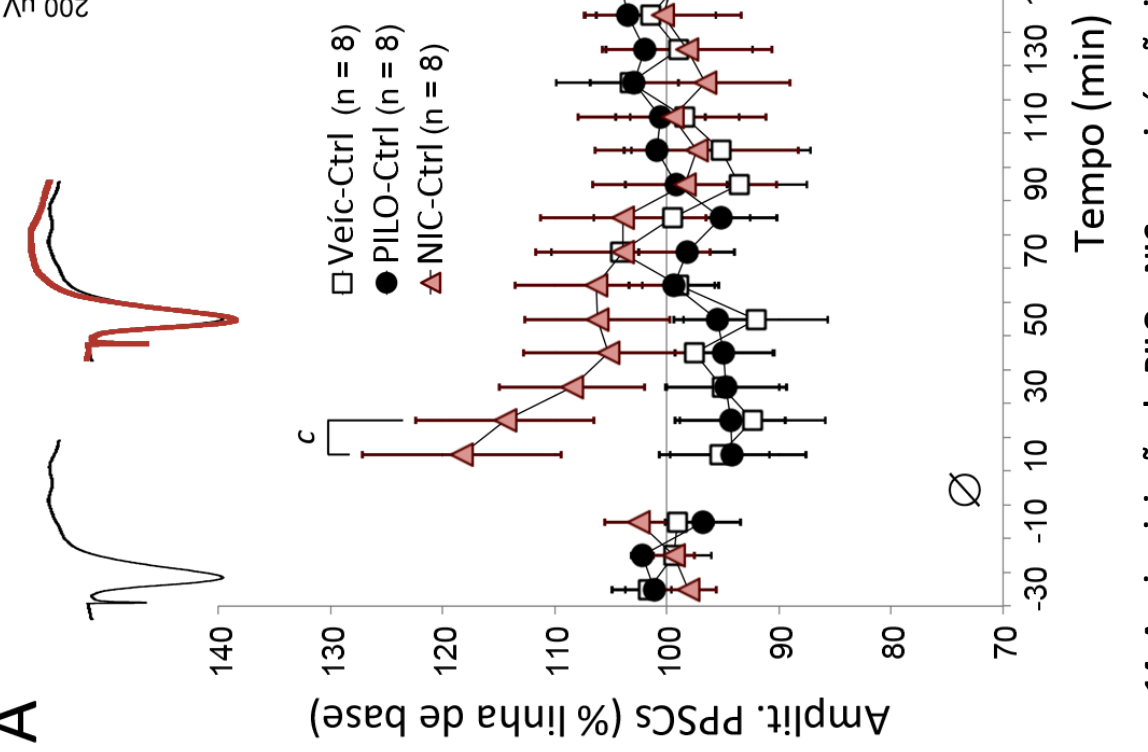
产

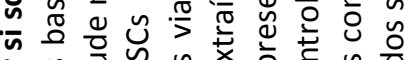

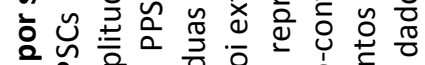

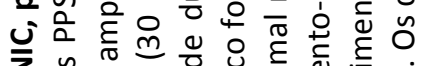

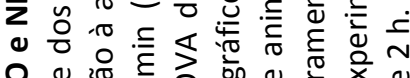
㐿

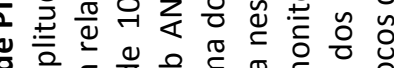

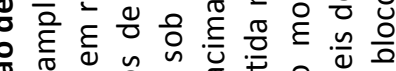
焉

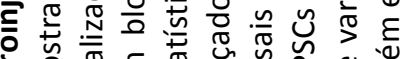

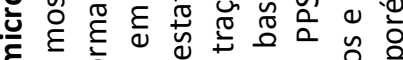
ব 원 பं

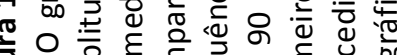

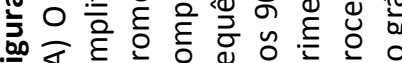




\subsection{A aplicação dos agonistas, por si só, não afetou os PPSCs a longo prazo}

Se por um lado PILO e NIC modularam igualmente os efeitos da EAF e EBF sobre os PPSCs pré-frontais, os agonistas sozinhos (ou seja, desacompanhados de EAF e EBF) não afetaram as respostas pré-frontais a longo prazo, o que indica ausência de plasticidade póssináptica de longa duração (Fig. 14). Embora tenhamos observado uma potencialização breve induzida pela injeção de NIC (efeito de interação: $F_{(46,480)}=2,15 ; P=0,001$ ), a potencialização não se sustentou, pois a amplitude dos PPSCs retomou o nível basal dentro de 30 min (Fig. 14). Estes dados de controle eletrofisiológico são importantes, pois garantem que os resultados dos experimentos com EAF e EBF são, de fato, devidos à interação entre os mecanismos sinápticos desencadeados pelos trens de pulsos e os estados colinérgicos globais transitoriamente promovidos pela injeção intraventricular de PILO e NIC.

\subsection{As mudanças nos PCLs foram correlacionadas com o pico da PLD pré-frontal}

Juntando-se todos os ratos que receberam EAF, independentemente da substância injetada no VL, encontramos correlações negativas entre a diminuição na potência em delta (tanto no CPFm quanto Tmd) e o aumento nas amplitudes dos PPSCs ao longo de todo o monitoramento, especialmente a partir dos $120 \mathrm{~min}$. Além disto, observamos correlações positivas entre o aumento em teta, beta e gama (no CPFm, especificamente) e o aumento dos PPSCs, principalmente a partir dos $120 \mathrm{~min}$. Em termos gerais, isto significa que quanto menor a potência em delta e quanto maior a potência em ondas rápidas após a microinjeção, maior a amplitude dos PPSCs a partir de 120 min após EAF. A Figura 15 ilustra correlações lineares referentes aos PPSCs evocados 120-150 min após EAF. Este foi o ponto temporal em que as correlações mais se concentraram, coincidindo aproximadamente com o pico da PLD previamente apresentada na Figura 12. Os valores estatísticos das correlações significativas são mostradas nos gráficos correspondentes (Fig. 15).

Correlações lineares significativas também foram encontradas no agrupamento de todos os animais que receberam EBF. Porém, elas foram menos frequentes e distribuídas 
esparsamente somente durante os primeiros $150 \mathrm{~min}$ do monitoramento pós-EBF. Os resultados significativos foram basicamente restritos às bandas delta (correlações negativas) e teta (correlações positivas) registradas tanto no CPFm quanto Tmd (por exemplo, no terceiro bloco de $10 \mathrm{~min}$, Delta no CPFm: $r=-0,52, P=0,038$; Teta no CPFm: $r=0,54, P=$ 0,032; no segundo bloco de $10 \mathrm{~min}$, Delta no Tmd: $r=-0,50, P=0,026$; Teta no Tmd: $r=-$ $0,49, P=0,028)$. Portanto, decréscimos na potência em delta e aumentos em teta logo após a microinjeção se correlacionaram com PPSCs de maior amplitude durante a primeira metade do monitoramento. Isto é coerente com a supressão da DLD induzida por PILO e NIC nos experimentos envolvendo EBF.

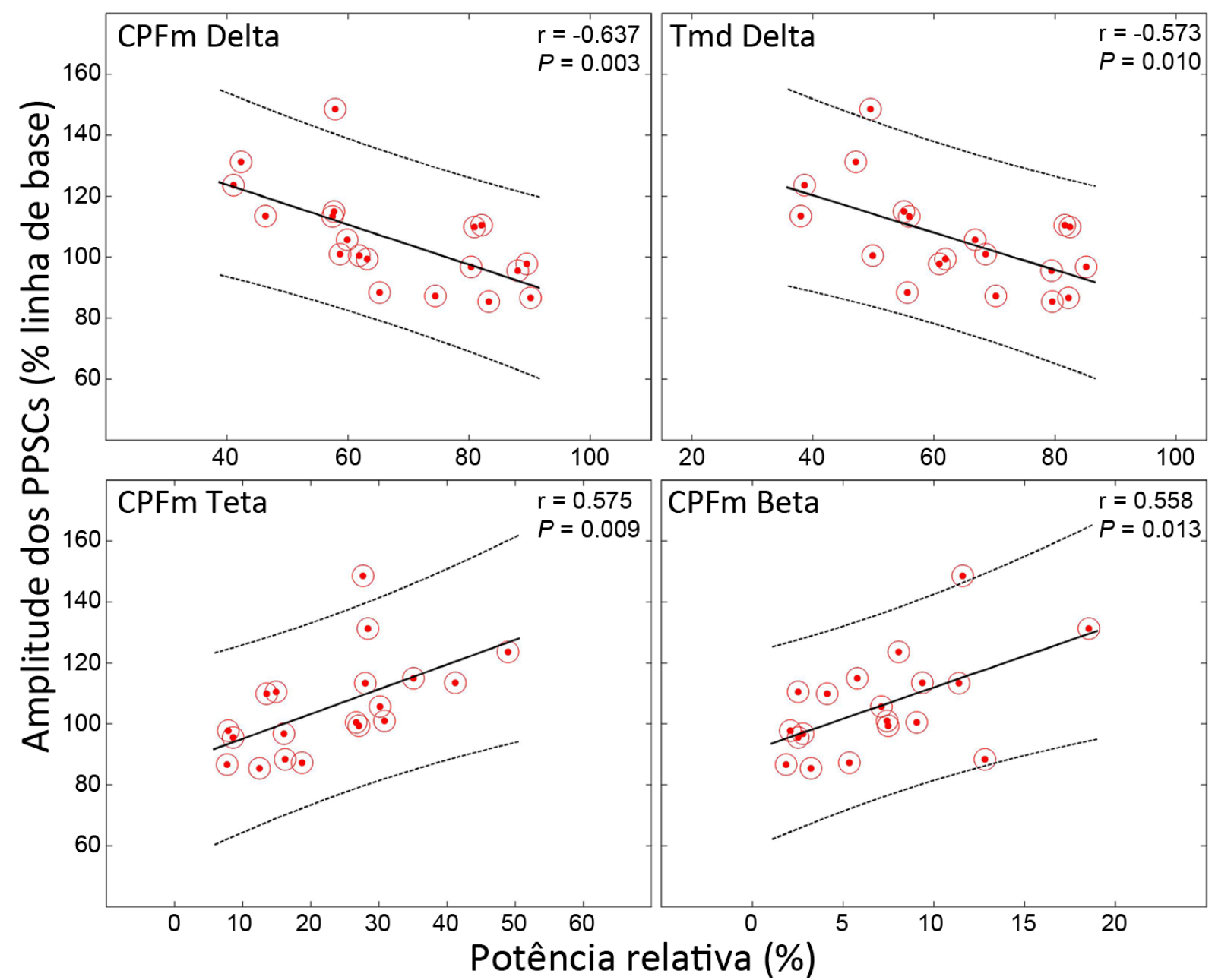

Figura 15. Os efeitos de PILO e NIC prévios à EAF foram correlacionados com a PLD que se manifestou mais de duas horas depois. Os quatro gráficos representam correlações lineares de Pearson entre as mudanças nos PCLs pré-EAF e a potencialização de PPSCs 120-150 min pós-EAF. Este período pós-EAF conteve a maior concentração de correlações entre as bandas de frequências (especialmente delta no CPFm e Tmd, e teta-beta no CPFm) e as amplitudes de PPSCs em blocos de $10 \mathrm{~min}$. Quanto menor a potência delta no CPFm e Tmd préEAF, maior a amplitude dos PPSCs 120-150 min após EAF (gráficos superiores). Quanto maior a potência tetabeta no CPFm pré-EAF, maior a amplitude dos PPSCs 120-150 min após EAF. 


\subsection{Experimento complementar: facilitação pré-sináptica por pulsos pareados}

Nossos picos negativos N1 e N2 (Fig. 10) tiveram latências similares às dos componentes dos PPSCs de Herry et al. ${ }^{149}$ e Herry e Garcia ${ }^{150}$. Porém, os autores descreveram seus PPSCs como deflexões positivas, ao contrário do que nós observamos. A distinção pode ter vários motivos, como as espécies de roedores, e posicionamento e características dos eletrodos. Por si só, o perfil temporal das respostas unitárias coletadas por Pirot et al. ${ }^{124-126}$ poderia ser considerado suficiente para a interpretação dos componentes dos PPSCs, independentemente de sua direção no eixo de microvolts. Foi exatamente deste modo que Herry et $a^{149}{ }^{149}$ e Herry e Garcia ${ }^{150}$ procederam. Nós, diferentemente, julgamos necessária uma segurança maior de que nosso componente N2 poderia ser atribuído a despolarizações pós-sinápticas no CPFm. Nossa estratégia foi a de medir a plasticidade sináptica de curta duração por aplicação de pulsos pareados no Tmd. Pulsos pareados separados entre si por $20-500$ ms causam facilitação de curta duração ${ }^{280}$, ou seja, o PPSC eliciado pelo segundo pulso tem amplitude maior do que o primeiro PPSC. Resumidamente, aceita-se que esta potencialização reflita uma facilitação à neurotransmissão, através de mecanismos regulados pela concentração de $\mathrm{Ca}^{2+}$ no terminal pré-sináptico. Um modelo possível é o do acúmulo de $\mathrm{Ca}^{2+}$ : o potencial de ação eliciado pelo primeiro pulso gera influxo de $\mathrm{Ca}^{2+}$ através de seus canais dependentes de voltagem. Com o segundo potencial de ação (20-500 ms depois), o influxo acumulado de $\mathrm{Ca}^{2+}$ potencializaria a exocitose das vesículas e, consequentemente, a liberação de seu conteúdo neurotransmissor.

Caso o componente N2 de nosso PPSC correspondesse à despolarização póssináptica de células corticais (inervadas pelos ramos axonais recrutados por estimulação antidrômica), ele deveria ser passível de facilitação por pulsos pareados. De fato, foi o que observamos. A Figura 16 mostra os dados de um experimento com oito animais. $\mathrm{O}$ procedimento usado foi o de aplicar pulsos pareados com intervalo entre pulsos de 5, 10, 20, 40, 80, 160, 320 e 480 ms. Para cada intervalo entre pulsos promediamos 3 pares de PPSCs. Os resultados (Fig. 16) indicaram não só potencialização de N2, mas também deslocamento de sua latência para até 18 ms. O fato de N2 ter sido potencializado em até 200\% sugere que o componente tardio de nossos PPSCs refletiu a neurotransmissão glutamatérgica 

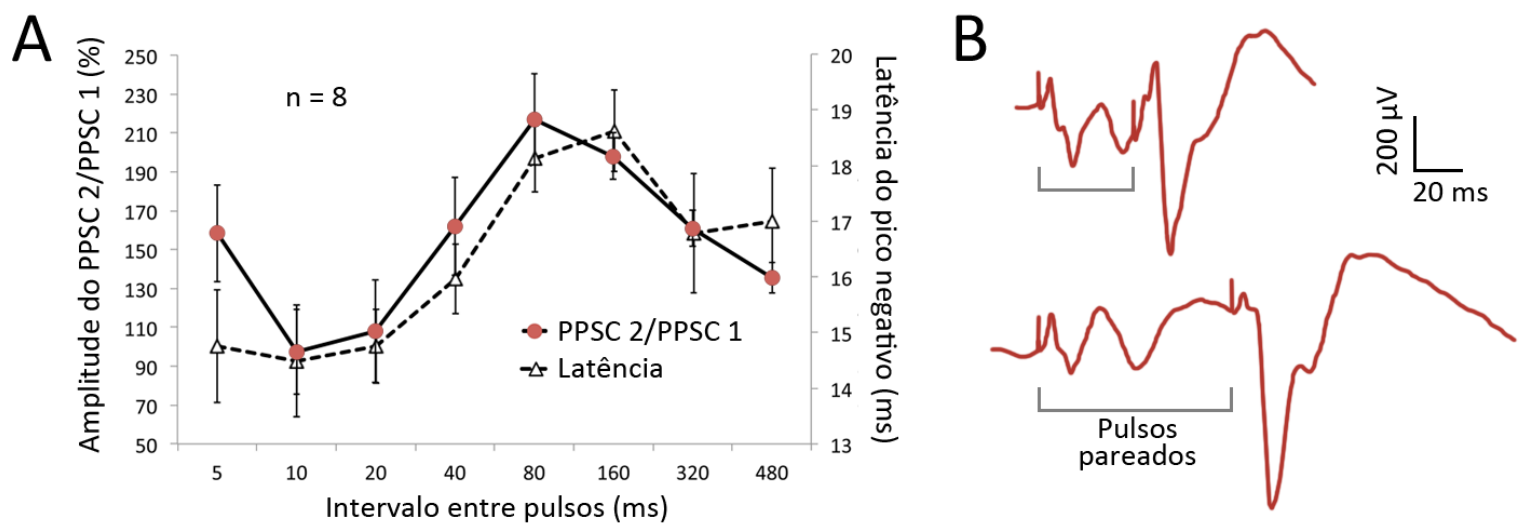

Figura 16. O pico negativo das respostas pré-frontais evocadas pelo Tmd é passível de facilitação por pulsos pareados, o que constitui evidência adicional da sua natureza pós-sináptica. (A) O gráfico compara duas curvas sobrepostas, correspondentes a dimensões distintas no eixo de ordenadas: a porcentagem de potencialização do segundo PPSC em relação ao primeiro e a latência do pico negativo do segundo PPSC. Ambas as dimensões variaram com o intervalo entre pulsos (eixo de abscissas). Tanto a amplitude do PPSC quanto a latência de seu pico negativo aumentaram com a aplicação do segundo pulso, especialmente quando os pulsos pareados foram separados por 80 ou $160 \mathrm{~ms}$. (B) O traçado mostra PPSCs representativos evocados por pulsos pareados (intervalo de $40 \mathrm{~ms}$ ), ilustrando que o segundo pulso induz aumento da amplitude de N2. 
O presente estudo é o primeiro a mostrar como a ativação colinérgica global afeta a plasticidade sináptica pré-frontal induzida por estimulação do tálamo. Nossos dados indicam que: (1) tanto a ativação muscarínica quanto a nicotínica potencializaram temporariamente ( 10-15 min) PCLs corticais e talâmicos em frequências rápidas (teta-gama); (2) a EAF induziu uma PLD tardia (mais de $2 \mathrm{~h}$ de latência) somente quando aplicada durante o estado transitório de oscilações rápidas; (3) opostamente, quando a EBF foi aplicada durante o mesmo estado oscilatório, uma DLD estável com pelo menos 4 h de duração foi suprimida; (4) nenhum destes efeitos de longo prazo sobre os PPSCs foi observado quando a ativação colinérgica ocorreu sozinha, ou seja, desacompanhada de EAF ou EBF; e (5) embora os efeitos das drogas colinérgicas sobre os PCLs tenham durado apenas alguns minutos, eles foram consistentemente correlacionados com a supressão da DLD e, principalmente, manifestação tardia da PLD horas depois. Uma primeira conclusão parcimoniosa é que a estimulação do Tmd modulou a transmissão excitatória contida, no mínimo, dentro da alça Tmd-CPFm. Ora, nós padronizamos a concentração das drogas de modo que a duração da ativação colinérgica coincidisse, aproximadamente, com a duração de EAF e EBF. Portanto, uma segunda conclusão possível é que os mecanismos excitatórios do circuito Tmd-CPFm interagiram com a ativação colinérgica durante uma janela temporal restrita, desencadeando efeitos de longo prazo sobre a função pré-frontal. Mais especificamente, o requisito à expressão da PLD foi a modulação colinérgica, enquanto o requisito à expressão da DLD foi a ausência dela.

Nossos dados sugerem que a modulação colinérgica encefálica potencializa o sinal talâmico no CPFm de forma duradoura. Embora estes achados, por si só, contribuam ao entendimento da função pré-frontal sob alerta e sono paradoxal, seu significado funcional pode ficar mais claro no contexto da rede aferente ao CPFm. Assim, convém fazer comparação com a via hipocampo-CPFm, que é a mais investigada ${ }^{258,264,281}$. Estudos prévios $^{261,266,267}$ de nosso laboratório mostraram que a modulação muscarínica global por PILO favoreceu tanto PLD quanto DLD na via hipocampo-CPFm. Ou seja, enquanto a modulação muscarínica potencializou a plasticidade hipocampo-CPFm bidirecionalmente, a mesma modulação favoreceu somente a PLD no circuito Tmd-CPFm. Além disto, a cinética e magnitude da plasticidade nos dois circuitos também foram contrastantes. Na via hipocampo-CPFm, a EAF induziu uma PLD imediata superior a 200\% que decaiu para até $\sim 150 \%$ dentro de $2-4 \mathrm{~h}$, e tal decaimento foi atenuado pela ativação muscarínica ${ }^{266,267}$. Por 
outro lado, no circuito Tmd-CPFm não houve PLD imediata. Ao invés disto, a PLD se manifestou a partir de $2 \mathrm{~h}$ após EAF chegando ao modesto patamar de $130 \%$, sendo que este efeito requereu a ativação muscarínica. No caso da DLD, a cinética estável e a magnitude de $\sim 85 \%$ foi similar entre os dois circuitos, apesar de PILO ter favorecido a DLD somente na via hipocampo-CPFm ${ }^{261}$. Como se vê, as comparações dizem respeito apenas à modulação muscarínica por PILO, que foi a única manipulação colinérgica usada nos trabalhos prévios ao presente estudo. No caso do circuito Tmd-CPFm nós mostramos que os efeitos de longo prazo da modulação nicotínica por NIC foram iguais aos de PILO. Este resultado é interessante, considerando-se que as ações e localizações das duas famílias de receptores colinérgicos são distintas ${ }^{210,211,223,227}$.

Em geral, os achados sugerem que as atividades convergentes ao CPFm são diferencialmente reguladas, dependendo do contexto oscilatório promovido pelo sistema colinérgico. Mais adiante, proporemos especulações sobre esta regulação diferencial, com ênfase à interface talâmica e hipocampal que ocorre dentro do CPFm. De qualquer forma, nossa contribuição começa a esclarecer a plasticidade pré-frontal em rede. Afinal, a literatura carece de estudos mostrando, de maneira integrada, como as entradas ao CPFm interagem em meio aos estados de neuromodulação ascendente. De fato, afora a via hipocampo-CPFm, ainda há poucas informações sobre a plasticidade em outros circuitos, como Tmd-CPFm ${ }^{149,150,268,269}$ e amígdala-CPFm ${ }^{282,283}$. Além disto, os poucos estudos com neuromodulação da plasticidade pré-frontal in vivo se restringem à modulação aminérgica ${ }^{284-286}$, e a maioria dos trabalhos sobre modulação dopaminérgica do CPFm utilizaram a preparação in vitro ${ }^{287-290}$. Esperamos, portanto, que nossas discussões abram caminho a novas estratégias in vivo que acessem a plasticidade sináptica em rede, em busca de implicações mais completas e realistas da flexibilidade funcional do CPFm.

Antes de propormos o raciocínio generalista sobre a modulação colinérgica e estados oscilatórios, é necessário comentarmos sobre os possíveis mecanismos celulares e sinápticos que nossas manipulações teriam desencadeado no CPFm. 


\subsection{Possível envolvimento de receptores NMDA}

Retomemos rapidamente conceitos apresentados na revisão da literatura. (1) Pulsos elétricos aplicados dentro do Tmd eliciam respostas unitárias no CPFm que são dependentes de receptores AMPA e NMDA, sendo que a função NMDA é concentrada na comunicação colateral entre células piramidais corticotalâmicas (camadas V-VI) recrutadas na direção antidrômica $^{125,129}$. (2) PLD e DLD dependentes de NMDA são os tipos de plasticidade sináptica mais prevalentes e investigados de todo o encéfalo, sendo presentes inclusive em circuitos talamocorticais ${ }^{11,28,140,145}$. (3) A ativação de receptores NMDA depende tanto do potencial de membrana quanto da ligação de glutamato, e diferentes níveis de influxo de $\mathrm{Ca}^{2+}$ mediados pelos receptores NMDA modulam de maneiras distintas a sinalização intracelular ${ }^{140}$. (4) A ação metabotrópica dos receptores muscarínicos do grupo-M $\mathrm{M}_{1}$ (preferencialmente pós-sinápticos) torna o potencial de repouso menos negativo ao reduzir indiretamente a condutância membranar de $\mathrm{K}^{+}$, além de promover a liberação de $\mathrm{Ca}^{2+}$ no citossol a partir de estoques intracelulares por meio da cascata de inositol trifosfato ${ }^{211-213}$. (5) A ação ionotrópica dos receptores nicotínicos $\alpha 4 \beta 2$ e $\alpha 7$ (preferencialmente présinápticos) promove de modo direto uma despolarização dependente de $\mathrm{Na}^{+}$e $\mathrm{Ca}^{2+}$, e tal influxo de $\mathrm{Ca}^{2+}$ participa da modulação da sinalização intracelular, em última análise potencializando a liberação de neurotransmissores como o glutamato ${ }^{223-226}$.

Nossos dados mostram que o condicionamento glutamatérgico do circuito TmdCPFm, simulado por EAF e EBF, e a modulação colinérgica global, simulada pela injeção intraventricular de PILO e NIC, interagem na indução de plasticidade sináptica. A plasticidade Tmd-CPFm ainda não havia sido testada sob nenhum tipo de modulação neuroquímica, nem mesmo a glutamatérgica. Considerando-se que o alcance de nossos resultados é preferencialmente fisiológico, eles poderão inspirar novos experimentos de dissecção farmacológica diretamente interessados nos mecanismos sob a interação glutamatérgica e colinérgica no CPFm. Mesmo assim, a literatura disponibiliza evidências que nos permitem discutir como funcionaria tal interação, a começar pela participação dos receptores NMDA na plasticidade pré-frontal. Pirot et al. $(1994)^{124}$ descreveram que pulsos elétricos no Tmd evocam duas categorias de respostas unitárias no CPFm, distinguidas conforme a latência (curta ou longa). Em seguida, Pirot et al. (1995) ${ }^{125}$ indicaram que as respostas de latência 
curta (células piramidais da camada III) são reduzidas pelo bloqueio local de receptores AMPA mas não NMDA, enquanto as de latência longa (células piramidais das camadas V-VI) são reduzidas pelo bloqueio de ambos os tipos de receptores. As respostas unitárias de latência longa corresponderiam ao segundo componente dos PPSCs pré-frontais evocados pelo Tmd, conforme a interpretação feita por Herry et al. (1999) ${ }^{149}$, por Herry e Garcia $(2002)^{150}$, e por nós. Ora, o segundo componente destes PPSCs é o mais sensível (se não o único sensível) à indução de plasticidade sináptica de longa duração. Portanto, podemos propor indiretamente que tal plasticidade é dependente de NMDA, e que ela reflete principalmente a despolarização de células piramidais das camadas V-VI e seus dendritos.

O traçamento anatômico mostra que, nas camadas $\mathrm{V}-\mathrm{VI}$, as células piramidais inervadas pela via hipocampo-CPFm são compartilhadas com o circuito Tmd-CPFm ${ }^{255,270-}$ ${ }^{272,291}$. Assim, caso a literatura evidenciasse diretamente que a plasticidade hipocampo-CPFm depende de NMDA, o envolvimento destes receptores na plasticidade Tmd-CPFm ficaria ainda mais plausível. De fato, a literatura fornece tais evidências, embora elas provenham somente de dois estudos. No primeiro, Jay et al. $(1995)^{260}$ confirmaram que a PLD na via hipocampo-CPFm depende de NMDA. No segundo, a partir de nosso próprio laboratório, Lopes-Aguiar et al. $(2012)^{261}$ mostraram que a DLD hipocampo-CPFm também depende de NMDA. Como mencionado na revisão que iniciou o presente texto, são justamente as camadas $\mathrm{V}-\mathrm{VI}$ do CPFm que enviam as principais projeções corticotalâmicas ao Tmd. Portanto, é razoável supor que a plasticidade hipocampo-CPFm exerça uma regulação de longo prazo sobre a via corticotalâmica CPFm-Tmd, o que tem importantes implicações ao nosso raciocínio de plasticidade em rede, destacado mais adiante.

Abrindo um parêntese, os PPSCs refletem despolarizações populacionais sem distinção clara quanto às camadas corticais, células e elementos subcelulares. Por isto, o implante do eletrodo de registro deve ser maximamente padronizado ao longo dos experimentos. Este cuidado reduz a inconsistência causada pela variação de posicionamento do eletrodo em relação às camadas corticais. No caso do CPFm, a padronização do implante é facilitada pelas características anatômicas desta área cortical. Em roedores, o plano laminar do CPFm é perpendicular ao plano horizontal do encéfalo, de modo que o implante vertical do eletrodo de registro é sempre paralelo às camadas. Assim, a inevitável variação quanto ao posicionamento do eletrodo no eixo dorso-ventral é mais indiferente no CPFm do que na maioria das outras áreas corticais ${ }^{119}$. Além disto, as áreas $\operatorname{PrL}$ e IL do CPFm são 
relativamente estreitas (espessura de $\sim 1 \mathrm{~mm}$ ) em comparação com a maior parte do córtex de roedores (espessura de $\sim 2 \mathrm{~mm}$ ), aumentando a representatividade dos PPSCs quanto ao conjunto de camadas a despeito da variação de posicionamento médio-lateral ${ }^{119}$.

\subsection{Possível interação entre receptores colinérgicos e glutamatérgicos}

Em geral, o contexto anatômico e eletrofisiológico prévio ${ }^{125,129,260,261}$ favorece a noção de que a plasticidade pré-frontal induzida a partir do Tmd depende de receptores NMDA pós-sinápticos. Com isto em mente e mantendo-se o foco no CPFm, pode-se discutir sobre a coativação entre receptores NMDA e muscarínicos do grupo- $\mathrm{M}_{1}$ possivelmente deflagrada por nossos experimentos com PILO. Em 1992, Müller e Connor ${ }^{292}$ utilizaram fatias hipocampais in vitro (cobaias), e monitoraram a concentração de íons $\mathrm{Ca}^{2+}$ nos dendritos de CA3 (microfluorometria) conforme a estimulação elétrica destas células piramidais. A estimulação gerou acúmulos transitórios de $\mathrm{Ca}^{2+}$, que mostraram um gradiente decrescente dos espinhos aos ramos dendríticos. Segundo os autores, os efeitos da estimulação sobre a concentração de $\mathrm{Ca}^{2+}$ foram potencializados pela ativação de receptores muscarínicos, e tal ação muscarínica foi acompanhada pela redução da condutância de $\mathrm{K}^{+}$e consequente despolarização. Outro resultado é que os acúmulos de $\mathrm{Ca}^{2+}$ favorecidos por receptores muscarínicos foram dificultados pelo bloqueio de receptores NMDA, mas este bloqueio só ocorreu nos espinhos dendríticos. Conjuntamente, os achados indicaram uma cooperação entre receptores NMDA e muscarínicos nos espinhos dendríticos ${ }^{292}$. Desde então, autores como John Lisman ${ }^{293}$, Cliff Abraham ${ }^{294}$, Alfredo Kirkwood ${ }^{295}$ e colaboradores vêm utilizando experimentos em fatias encefálicas in vitro para demonstrar que a cooperação entre receptores NMDA e muscarínicos regula a plasticidade sináptica. A cooperação ocorre em regiões como o córtex piriforme ${ }^{296}$, córtex insular ${ }^{297}$, córtex visual ${ }^{298}, \mathrm{CA}^{299-302}$, subículo $^{303} \mathrm{e}$ estriado $^{304}$. No CA1, oscilações teta induzidas por modulação muscarínica favorecem PLD e DLD dependente de NMDA $^{293}$. Ainda em CA1, o acúmulo de peptídeos $\beta$-amiloides em modelos transgênicos da doença de Alzheimer prejudica tanto a ação muscarínica quanto as correntes mediadas por NMDA, o que contribui à perda cognitiva e mnemônica ${ }^{305,306}$. No CA1 e giro denteado, a coativação de receptores NMDA e muscarínicos aumenta a expressão 
de genes imediatos associados à plasticidade sináptica ${ }^{294}$. No córtex visual, a plasticidade evocada por estimulação sensorial é potencializada pela ativação muscarínica, que também interage com a ativação noradrenérgica ${ }^{295,307-309}$.

A cooperação colinérgica à plasticidade dependente de NMDA também inclui os receptores nicotínicos, embora a interação destes receptores com canais NMDA possa ser indireta conforme a região encefálica e subcelular. Na experimentação em fatias encefálicas in vitro, autores como John Dani ${ }^{310}$, Huibert Mansvelder ${ }^{311}$, Daniel McGehee ${ }^{312}$ e colaboradores têm concentrado esforços na modulação nicotínica da plasticidade no hipocampo e ATV. Em terminais pré-sinápticos sobre CA1, Nishizaki et al. (1999) mostraram que as correntes catiônicas mediadas por receptores $\alpha 4 \beta 2$ e $\alpha 7$ aumentaram a liberação de glutamato potencializando a neurotransmissão por até $3 \mathrm{~h}$, e tal efeito duradouro dependeu de cascatas envolvendo a proteína cinase C. A potencialização da neurotransmissão mostrou-se independente de NMDA, mas mesmo assim os autores sugeriram que ela poderia contribuir indiretamente à PLD dependente de NMDA ${ }^{313}$. Diferentemente, Mann e Greenfield (2003) ${ }^{314}$ mostraram que receptores $\alpha 7$ podem facilitar diretamente a PLD dependente de NMDA no CA1. A discrepância encontrada no CA1 pode ser atribuída a um contexto complicado, no qual receptores $\alpha 4 \beta 2$ e $\alpha 7$ estão presentes tanto em terminais pré-sinápticos quanto células piramidais e interneurônios pós-sinápticos ${ }^{315}$. A complicação é aumentada pelo fato de que os dois tipos de receptores nicotínicos, com suas diversas permeabilidades ao $\mathrm{Ca}^{2+}$, poderiam contribuir diferencialmente ao influxo de $\mathrm{Ca}^{2+}$ mediado por NMDA, regulando a polaridade (PLD ou DLD) da plasticidade sináptica ${ }^{315-319}$. Na ATV, particularmente rica em receptores $\alpha 4 \beta 2$ e $\alpha 7^{227,320}$, o contexto nicotínico parece ser mais trivial. Reconhece-se, de modo geral, que receptores nicotínicos em terminais présinápticos facilitam a liberação de glutamato sobre células pós-sinápticas dopaminérgicas, o que por sua vez potencializa a influência dopaminérgica ascendente. A permanência de tal potencialização seria devida ao aumento da exposição pós-sináptica de AMPA em relação a NMDA, e este mecanismo ajudaria a explicar a dependência à nicotina ${ }^{310,312,320-322}$. Finalmente, em modelos animais da doença de Alzheimer, os peptídeos $\beta$-amiloides também afetam a contribuição nicotínica à plasticidade ${ }^{323,324}$.

Apesar da diversidade de interações entre receptores colinérgicos e NMDA na plasticidade sináptica, os estudos in vitro deixam como legado um modelo representando os mecanismos básicos sob estas interações. No caso dos receptores do grupo- $\mathrm{M}_{1}$, o ponto de 
convergência na interação com NMDA está na regulação da concentração pós-sináptica de cálcio, principalmente em espinhos dendríticos ${ }^{292}$. A ação metabotrópica do grupo- $\mathrm{M}_{1}$ diminui a condutância de $\mathrm{K}^{+}$ao modular a composição da bicamada lipídica via fosfolipase $\mathrm{C}^{212}$, o que acaba tornando o potencial de repouso menos negativo e contribuindo às correntes de $\mathrm{Ca}^{2+}$ mediadas por canais $\mathrm{NMDA}^{325}$. Além de sua ação despolarizante, a cascata da fosfolipase $C$ ativada pelo grupo- $M_{1}$ gera inositol trifosfato responsável pelo vazamento de cálcio a partir do retículo endoplasmático, e este efeito também converge à regulação do cálcio intracelular ${ }^{325}$. Em última análise, a oscilação do cálcio citossólico comodulada por NMDA e receptores do grupo-M1 afeta ações citoesqueléticas subjacentes à inserção ou remoção de receptores AMPA da densidade pós-sináptica ${ }^{140,326}$.

Por sua vez, a ação nicotínica também utiliza a maquinaria celular regulada pela concentração de cálcio, mas isto ocorre predominantemente em terminais pré-sinápticos glutamatérgicos ${ }^{327}$. A acetilcolina extracelular em baixas concentrações ativa preferencialmente os receptores de alta afinidade $\alpha 4 \beta 2$. Uma vez ativados, os $\alpha 4 \beta 2$ mediam influxo de $\mathrm{Na}^{+}$e $\mathrm{Ca}^{2+}$ em proporções equilibradas. Isto despolariza o terminal, favorecendo a abertura de canais de cálcio dependentes de voltagem. A consequência disto é a exocitose dependente de $\mathrm{Ca}^{2+}$, seguida da liberação do conteúdo neurotransmissor a partir das vesículas $^{327}$. Porém, o efeito mediado por $\alpha 4 \beta 2$ é efêmero em comparação com o efeito de receptores $\alpha 7$ que, para serem ativados, requerem concentrações altas de acetilcolina (ou,

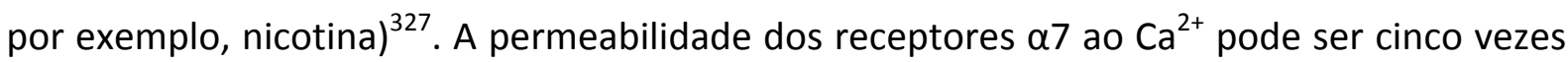
maior do que a de receptores $\alpha 4 \beta 2$, de modo que sua abertura promove grande influxo do cátion. $\mathrm{A}$ invasão aumentada de $\mathrm{Ca}^{2+}$ não só mobiliza as vesículas, mas também regula as cascatas de fosforilação responsáveis pela potencialização da neurotransmissão em longo prazo $^{327}$. Embora este modelo pré-sináptico não inclua receptores NMDA, estes acabam sendo afetados pela disponibilidade de glutamato na fenda sináptica, aumentada pela regulação nicotínica ${ }^{327}$. Ressalte-se, porém, que receptores NMDA e $\alpha 7$ podem coexistir nos mesmos terminais prés ${ }^{328}$ ou pós-sinápticos ${ }^{315,320}$. Deste modo, ambos podem atuar concomitantemente no influxo de $\mathrm{Ca}^{2+}$, dependendo da região encefálica.

Os modelos de interação entre receptores glutamatérgicos e colinérgicos na plasticidade sináptica provêm de um corpo de evidências que não inclui investigações do CPFm. Apesar disto, é provável que os modelos sejam válidos, pelo menos parcialmente, ao CPFm, o que nos permite algumas suposições. Primeiro, os efeitos de nossos experimentos 
com PILO pré-EAF ou EBF refletiriam, no mínimo, a coativação de receptores pós-sinápticos NMDA e do grupo- $\mathrm{M}_{1}$ em células corticotalâmicas das camadas V-VI. Conforme revisado por Hasselmo e Sarter $(2011)^{188}$, a ação colinérgica sobre os neurônios piramidais eferentes do CPFm (inclusive neurônios corticotalâmicos) é basicamente mediada por receptores muscarínicos do grupo-M $M_{1}$. A ação colinérgica, quando coincidente com entradas glutamatérgicas subcorticais ou corticocorticais ao CPFm, parece ser necessária ao controle pré-motor do CPFm sobre o deslocamento de atenção conforme demanda ambiental ${ }^{188}$. Considerando-se que a coincidência glutamatérgica e colinérgica sobre as células eferentes do CPFm seja capaz de induzir plasticidade sináptica endogenamente, é possível que tal plasticidade controle a aprendizagem e adaptação dos comportamentos de orientação. Porém, o entendimento dos mecanismos muscarínicos no CPFm ainda é incompleto, principalmente quanto ao seu envolvimento na plasticidade sináptica.

Por sua vez, os efeitos da NIC pré-EAF ou EBF podem indicar facilitação à liberação de glutamato. Isto explicaria a potencialização breve (20-30 min) que observamos após aplicação da NIC sozinha, ou seja, desacompanhada de EAF e EBF nos grupos-controle. Enquanto presente no tecido, a NIC teria favorecido a abertura de canais pré-sinápticos $\alpha 4 \beta 2$ e/ou $\alpha 7$ em proporções desconhecidas, sem que o influxo de $\mathrm{Ca}^{2+}$ por meio dos canais chegasse a facilitar de maneira duradoura a liberação de glutamato. A ação nicotínica modula principalmente as entradas ao CPFm, diferentemente da modulação pelo grupo- $\mathrm{M}_{1}$, que regula a saída desta área cortical ${ }^{188}$. Os receptores nicotínicos do CPFm participariam da detecção de contingências entre estímulos ambientais e esta detecção, junto com o direcionamento atentivo dependente do grupo- $\mathrm{M}_{1}$, constituiria a base da contribuição colinérgica ao processamento pré-frontal na vigília ${ }^{188}$. Considerando-se que a facilitação présináptica nicotínica favorece a plasticidade pré-frontal através da potencialização de seu sinal aferente, é possível que tal plasticidade participe da detecção e memorização das relações de contingência entre eventos ambientais. Apesar das possíveis funções dos receptores $\alpha 4 \beta 2$ e/ou $\alpha 7$ no CPFm, novamente ressaltamos que faltam estudos diretamente interessados nos mecanismos nicotínicos envolvidos da plasticidade sináptica pré-frontal.

Em suma, as interações glutamatérgicas e colinérgicas na plasticidade sináptica do CPFm não são totalmente elucidadas. A incompreensão é ainda maior quando se consideram os mecanismos glutamatérgicos e colinérgicos em várias regiões encefálicas (por exemplo, células talamocorticais, núcleo TRt, ATV, estriado, hipocampo e outras áreas 
corticais) que, embora distantes do CPFm, podem contribuir indiretamente à sua plasticidade. Este pode ser o caso das nossas observações eletrofisiológicas. Embora continuem sendo viáveis as conjeturas sobre processos locais do CPFm, nossos dados escondem um conjunto de processos que são distribuídos e, possivelmente, condicionados pelos estados oscilatórios globais. Como já mencionado, o alcance de nossos achados é preferencialmente fisiológico. Assim, a partir daqui nos concentraremos na contextualização da plasticidade pré-frontal sob os estados oscilatórios promovidos por nossas manipulações. Acreditamos que o presente estudo esclarece mais diretamente a função hipocampocórtico-talâmica durante o sono, como argumentado a seguir.

\subsection{Ativação colinérgica no contexto da anestesia: imitando o sono paradoxal?}

Para a discussão dos dados a partir de um ponto de vista fisiológico, lembremos a revisão sobre a anestesia por uretana. Esta anestesia resguarda a capacidade do sistema colinérgico de promover estados oscilatórios rápidos ${ }^{246,249,250,253,254}$. De fato, a estimulação dos centros colinérgicos ponto-mesencefálicos sob uretana induz um estado oscilatório global similar ao do sono paradoxal ${ }^{252}$. Neste sentido, permear globalmente o encéfalo com agonistas colinérgicos durante a anestesia por uretana (por exemplo, pela via intraventricular, que é de fácil acesso) pode ser útil à imitação do sono paradoxal. Opostamente, o sono de ondas lentas também pode ser imitado. Para tanto, basta substituir os agonistas colinérgicos por uma substância-controle inócua, de modo a preservar o estado de oscilações lentas promovido pela uretana. Pois bem, tal estratégia foi utilizada no presente trabalho acerca do circuito Tmd-CPFm, assim como em trabalhos prévios de nosso laboratório que avaliaram PLD e DLD na via monossináptica CA1-CPFm²61,266,267.

No CA1 de ratos anestesiados com uretana, a aplicação da EAF sem ativação colinérgica, ou seja, durante o contexto com prevalência máxima de ondas delta, induziu uma PLD imediata superior a 200\% que decaiu para até 150\% dentro de 2-4 h. Quando a EAF foi aplicada durante a ativação colinérgica, ou seja, durante o período transitório em que a proporção de ondas rápidas esteve aumentada, a PLD foi fortalecida e teve seu decaimento desacelerado, embora a curva da PLD tenha permanecido decrescente ${ }^{266,267}$. No 
circuito Tmd-CPFm, nossos resultados quanto à PLD foram contrastantes. Primeiro, a PLD não foi sequer induzida quando a EAF foi aplicada no contexto oscilatório lento promovido pela anestesia. Ou seja, a ativação colinérgica foi requisito à PLD talamocortical. Segundo, a manifestação desta PLD teve uma latência de pelo menos $2 \mathrm{~h}$ em relação à aplicação da EAF, alcançando apenas $\sim 130 \%$ em relação à linha de base.

Temos em vista os seguintes pontos: (1) as curvas de PLD induzidas pelo CA1 e Tmd têm cinéticas distintas; (2) o estado de alta sincronização talamocortical promovido pela uretana equivaleria ao sono de ondas lentas; (3) a ativação colinérgica sob uretana imitaria o sono paradoxal; (4) o fluxo de informações do CA1/subículo ao CPFm é unidirecional e se direciona principalmente, embora não exclusivamente, a células piramidais das camadas VVI do CPFm ${ }^{255,291}$; e (5) a estimulação do Tmd recruta células piramidais pertencentes às mesmas camadas do CPFm, apesar de isto ocorrer na direção antidrômica ${ }^{124,129}$. Agora, com nosso levantamento teórico sobre oscilações talamocorticais, podemos propor uma dinâmica endógena de plasticidade em rede, que ocorreria no CPFm sob os diferentes estágios do sono. Faremos esta proposta em duas etapas: uma baseada na interpretação dos dados de PLD e outra que contextualiza PLD e DLD conjuntamente.

Comecemos pela intepretação da PLD. No sono de ondas lentas as entradas hipocampais ao CPFm não teriam condições de flexibilizar a modulação corticotalâmica CPFm-Tmd. Em outras palavras, no contexto da sincronização global entre tálamo e córtex (modo funcional de salvas), o CPFm estaria impedido de modular o Tmd, independentemente da atividade hipocampo-CPFm. Isto é coerente com a ausência de PLD no circuito Tmd-CPFm quando a EAF é aplicada durante o estado oscilatório lento. Isto também é coerente com o fato de que, durante o mesmo estado oscilatório, a via CA1-CPFm permanece capaz de sofrer uma PLD robusta, embora tal PLD seja ligeiramente mais fraca em comparação com a PLD modulada pela ativação colinérgica. O sono paradoxal, diferentemente, favoreceria tanto a potencialização do sinal hipocampo-CPFm quanto a flexibilização das entradas CPFm-Tmd, abrindo caminho à transferência hipocampo-córticotalâmica. Em mais detalhes, a influência hipocampal sobre as camadas V-VI do CPFm estaria potencializada pelo sono paradoxal. Enquanto isto, o mesmo estágio do sono instauraria uma janela temporária de permissividade ao fluxo corticotalâmico de informações. Isto condiz com nossa PLD no circuito Tmd-CPFm, que só ocorreu quando a EAF foi acompanhada de modulação colinérgica. Assim, o sinal hipocampocortical aumentado, junto 
com a abertura à comunicação corticotalâmica, tornaria o sono paradoxal um período privilegiado à transferência de informações do hipocampo ao CPFm, do CPFm ao Tmd e, consequentemente, do Tmd de volta ao CPFm. Isto é, durante o sono paradoxal, as entradas hipocampo-CPFm seriam traduzidas em novos padrões de reverberação excitatória na alça CPFm-Tmd-CPFm. O significado disto é que a conexão unilateral hipocampo-CPFm se desengajaria de determinadas informações, contanto que tais informações pudessem, na oportunidade propiciada pelo sono paradoxal, ser relegadas à reverberação excitatória CPFm-Tmd-CPFm. Afinal, possivelmente o CPFm não seria capaz de sustentar estas informações em longo prazo na ausência de sua relação funcional com o Tmd.

Podemos, agora, interpretar os dados de DLD no circuito Tmd-CPFm, comparando-os com os da DLD na via CA1-CPFm. Em contraste com os resultados de PLD resumidos acima, as curvas de DLD obtidas em CA1-CPFm e Tmd-CPFm são parecidas: aproximadamente estáveis ao longo das $4 \mathrm{~h}$ de monitoramento, e variando em torno de $80-85 \%$ em relação à linha de base. Porém há uma diferença importante. Na via CA1-CPFm sob uretana, a DLD estável só é observada quando sua indução ocorre durante a ativação colinérgica. Na ausência de ativação colinérgica, esta DLD também é induzida, porém se desvanece em 30$60 \mathrm{~min}$. Isto é, na via CA1-CPFm, a ativação colinérgica converte uma DLD efêmera numa DLD sustentada ${ }^{261}$. Opostamente, no circuito Tmd-CPFm a ativação colinérgica suprime a DLD. Ou seja, o mesmo estado oscilatório rápido favorável à sustentação da DLD na via CA1CPFm é desfavorável à DLD no circuito Tmd-CPFm. Na primeira etapa de nossas hipóteses, tentamos interpretar os resultados de PLD, propondo que o sono paradoxal promoveria uma transferência da potencialização ao longo da rede CA1-CPFm-Tmd-CPFm. Este cenário fisiológico já é, por si só, especulativo. Com a inclusão destes dados de DLD a especulação tende a aumentar. Mesmo assim, interpretar os dados de PLD e DLD conjuntamente é oportunidade para arriscar um cenário fisiológico mais generalista e passível de experimentação. Vamos, então, à segunda etapa de nossas propostas.

Diferentes frequências de estimulação (EAF ou EBF) regulam a polaridade da plasticidade sináptica (PLD ou DLD). Uma implicação disto é que a plasticidade em rede, pelo menos no circuito CA1-CPFm-Tmd-CPFm, poderia ser seletiva quanto aos padrões de atividade excitatória, e tal seletividade poderia ser diferencialmente regulada pelo sono de ondas lentas e sono paradoxal. No contexto de ondas lentas, a comunicação interna da alça Tmd-CPFm seria permissiva aos padrões de atividade com frequências igualmente lentas. 
Isto parece óbvio, tendo em vista que quaisquer circuitos talamocorticais são, nada mais nada menos, responsáveis pela sincronização do prosencéfalo em ondas lentas. Nossos dados de DLD são coerentes com esta permissividade. Afinal, a EBF, cuja frequência se encaixa na banda delta, induz DLD estável no circuito Tmd-CPFm, contanto que o contexto de ondas lentas da anestesia esteja intocado. Enquanto isto, na via CA1-CPFm, o mesmo contexto de ondas lentas estaria dificultando (sem, contudo, impossibilitar) a sustentação da DLD. Ora, apesar de a via CA1-CPFm ter dificuldade de sustentar a DLD induzida sob ondas lentas, ela continua capaz de sofrer PLD sem ativação colinérgica, mesmo que tal PLD seja ligeiramente mais fraca. Isto sugere que o sono de ondas lentas sujeitaria a via CA1-CPFm e o circuito Tmd-CPFm a dois filtros distintos. Na via CA1-CPFm, o filtro seria do tipo passaalta, pois a atividade em alta frequência nesta via continuaria sendo influente, mesmo sem a potencialização promovida pela ativação colinérgica. Por outro lado, o filtro imposto ao circuito Tmd-CPF seria de passa-baixa, com permissividade à depressão sináptica. Relembremos nosso primeiro conjunto de hipóteses, de que o sono de ondas lentas bloquearia a interferência hipocampal sobre a excitação corticotalâmica. Pois bem, agora podemos expandir a ideia: o sono de ondas lentas não somente obstruiria a transferência CA1-CPFm-Tmd, mas também deprimiria a excitação interna do circuito Tmd-CPFm, e tal depressão seria indiferente à atividade CA1-CPFm. Para ilustração, ver Figura 17.

No sono paradoxal, os filtros diferenciais seriam transformados. O fato de a ativação colinérgica fortalecer tanto a DLD quanto a PLD na via CA1-CPFm sugere que, no sono paradoxal, a comunicação CA1-CPFm estaria livre de filtros. Ou seja, padrões de atividade em frequências baixas e altas estariam igualmente favorecidos, facilitando a plasticidade sináptica bidirecional. Em contraste, o circuito Tmd-CPFm estaria submetido a um filtro passa-alta, inversamente ao que ocorreria sob ondas lentas. Assim, a via CA1-CPFm estaria passível de potencialização ou depressão no sono paradoxal. Por outro lado, a conexão corticotalâmica CPFm-Tmd estaria passível somente de potencialização. Isto significa que a transferência CA1-CPFm-Tmd propiciada pelo sono paradoxal só seria válida aos padrões de atividade em alta frequência. Ou seja, a atividade em baixa frequência na via CA1-CPFm não seria transmitida ao Tmd nem no sono de ondas lentas, nem no paradoxal. Pode-se supor, deste modo, que a potencialização sináptica no CPFm dependeria mutuamente de CA1 e Tmd, enquanto a depressão no CPFm teria duas origens independentes: uma contida no circuito Tmd-CPFm e outra promovida unilateralmente a partir do CA1 (Fig. 17). 

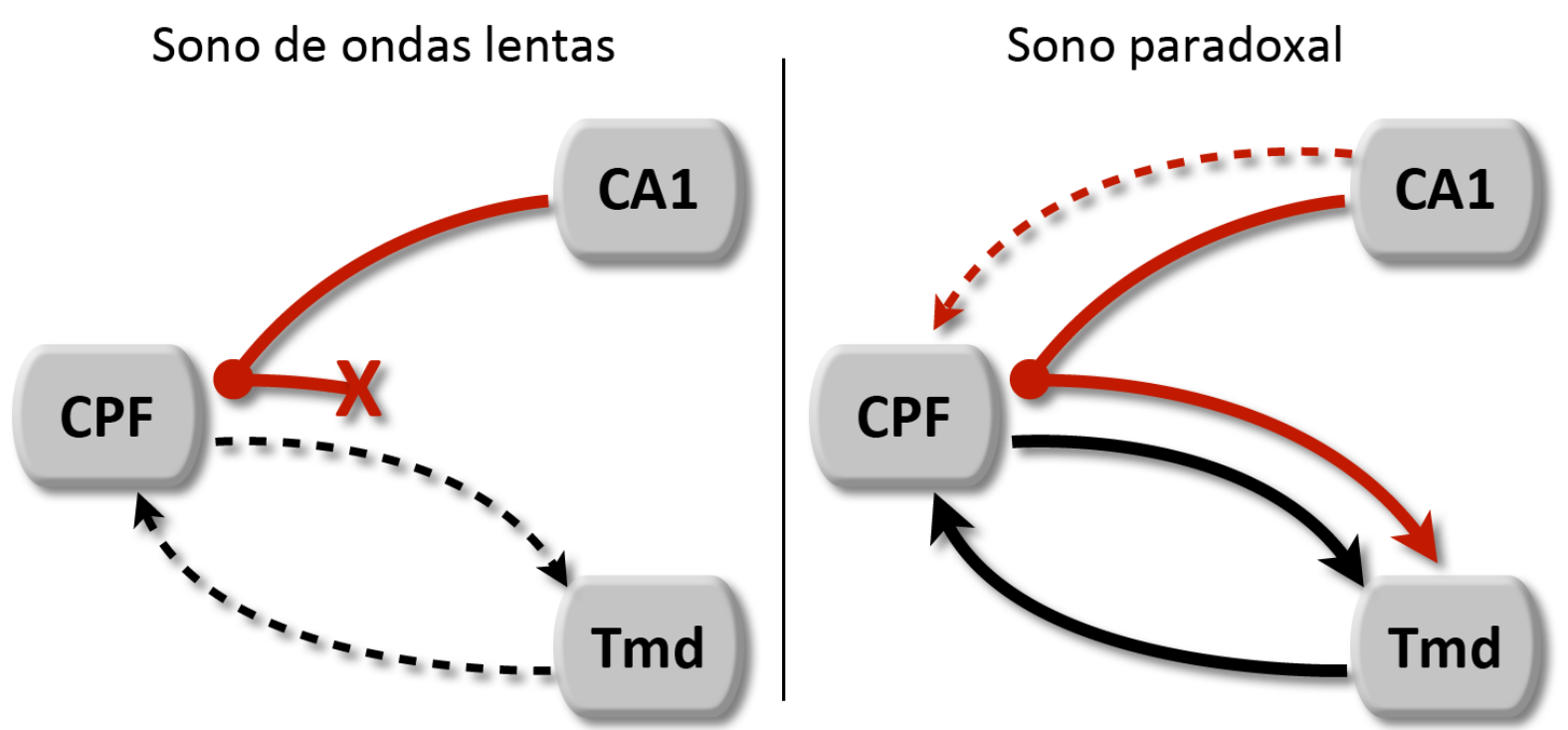

Figura 17. Modelo propondo a plasticidade em rede da via CA1-CPF e do circuito Tmd-CPF, bem como a regulação de tal plasticidade pelos estados oscilatórios do sono. As linhas e setas vermelhas representam projeções provenientes de CA1, e as pretas representam a comunicação recíproca entre Tmd e CPF. As linhas cheias indicam propensão à atividade em altas frequências (e, consequentemente, potencialização sináptica), e as tracejadas indicam propensão a baixas frequências (e, consequentemente, depressão sináptica). $\mathrm{O}$ círculo vermelho ao lado do CPF representa as camadas V-VI do CPF. Estas camadas contêm células piramidais que recebem aferências de CA1 e enviam eferências corticotalâmicas ao Tmd, completando o circuito CA1-CPFTmd-CPF. No sono de ondas lentas, a alça Tmd-CPF estaria propensa somente à atividade em baixas frequências. Tal depressão seria indiferente à atividade em altas frequências de CA1, cuja influência sobre as camadas V-VI do CPF seria incapaz de afetar a sincronia talamocortical. No sono paradoxal, o estado tônico talamocortical tornaria a comunicação Tmd-CPF permissiva às frequências altas, oferecendo condições para a transferência da atividade em altas frequências ao longo do circuito CA1-CPF-Tmd-CPF. Ainda no sono paradoxal, a via CA1-CPF também estaria passível de transmitir atividade em baixas frequências, o que explicaria o favorecimento da modulação colinérgica tanto à potencialização quanto à depressão na via CA1CPF. No entanto, a eventual depressão sináptica na via CA1-CPF não afetaria diretamente o circuito Tmd-CPF.

Em suma, nosso modelo propõe: (1) no sono de ondas lentas, a atividade no circuito Tmd-CPFm seria passível de depressão e estaria desacoplada da influência CA1-CPFm, que por sua vez estaria mais passível de potencialização do que depressão; (2) no sono paradoxal, a via CA1-CPFm seria plenamente sujeita à plasticidade bidirecional, mas somente sua potencialização conseguiria invadir a alça CPFm-Tmd-CPFm, aumentando sua reverberação excitatória (Fig. 17). Seria útil confrontar este modelo com dados da literatura. Porém, somente um trabalho estudou a plasticidade sináptica pré-frontal conforme o ciclo sono-vigília. Romcy-Pereira e Pavlides $(2004)^{265}$ se interessaram pelos efeitos da privação seletiva de sono paradoxal sobre a PLD no CPFm. Em ratos acordados, os autores induziram a PLD por EAF no CA1 posterior dorsal, que é a mesma região que viria a ser estimulada por Lopes-Aguiar et al. $(2008,2012)^{261,266}$ e Ruggiero et al. $(2010)^{267}$ em ratos anestesiados. Em seguida, no primeiro episódio de sono, Romcy-Pereira e Pavlides ${ }^{265}$ perturbaram o sono 
paradoxal logo que ele se manifestasse eletrograficamente, e a perturbação foi feita por manipulações gentis à câmara de registro eletrofisiológico. Os resultados indicaram que a privação do sono paradoxal desacelerou o decaimento da PLD, que só foi observado nos animais-controle com sono preservado. De acordo com os autores, o sono paradoxal poderia restaurar o funcionamento do CPFm, retirando-o de uma saturação sináptica que, nos episódios de vigília subsequentes, atrapalharia as operações cognitivas centralizadas pelo CPFm. Isto é coerente com estudos de imageamento encefálico e eletrencefalograma em humanos, que têm associado o aumento da atividade pré-frontal ao longo de dias com déficits cognitivos e de humor causados pela privação total ou parcial de sono ${ }^{329-332}$.

$\mathrm{Na}$ comparação dos achados de Romcy-Pereira e Pavlides ${ }^{265}$ com os modelos propostos aqui, uma interpretação possível é que a privação do sono paradoxal retiraria as janelas temporais de máxima plasticidade bidirecional da via CA1-CPFm. Em outras palavras, a ausência dos picos de ativação colinérgica do sono atrapalharia a depressão sináptica na via CA1-CPFm e, portanto, a capacidade de esta mesma via reverter uma potencialização adquirida previamente na vigília. Supondo o envolvimento do sono paradoxal na restauração da habilidade cognitiva, a sustentação anormal da PLD hipocampo-CPF seria prejudicial às funções executivas desta área cortical. Mantendo o raciocínio, migremos à plasticidade préfrontal induzida a partir do tálamo. Os achados e discussões de Herry et al. (1999) ${ }^{149}$ e Herry e Garcia (2002) ${ }^{150}$ caminham numa direção que, a princípio, parece contrária à de RomcyPereira e Pavlides ${ }^{265}$. Afinal, os autores franceses mostraram que, no circuito Tmd-CPFm de camundongos acordados, a DLD é prejudicial à flexibilidade comportamental, e não a PLD. Consistentemente, eles também mostraram que, na ausência de indução de plasticidade sináptica, a comunicação Tmd-CPFm sofre uma natural conversão da depressão à potencialização sináptica ao longo da extinção do medo condicionado, conforme revisado na primeira parte desta tese. Ora, a discussão de Herry et al. ${ }^{149}$ e Herry e Garcia ${ }^{150}$ passou ao largo do sistema colinérgico. Assim, é difícil definir os processos colinérgicos endógenos que teriam contribuído aos efeitos observados por estes autores. Mais difícil ainda é discutir a participação colinérgica durante as sessões de condicionamento/extinção ou nos episódios de sono entre sessões. De qualquer forma, pode-se sugerir que a DLD talamocortical de Herry et al. $^{149}$ e Herry e Garcia ${ }^{150}$ (tanto a DLD que os autores induziram intencionalmente, quanto a que ocorreu espontaneamente) teria bloqueado a transferência de uma 
potencialização hipocampo-CPFm ao circuito Tmd-CPFm, embora os autores não tenham testado a plasticidade hipocampo-CPFm e Tmd-CPFm conjuntamente nestes trabalhos.

Portanto, os dados e revisões do presente estudo unem discussões sobre plasticidade pré-frontal em rede que vinham se mostrando desarticuladas e escassas. Além disto, os modelos fisiológicos aqui propostos parecem se adequar a alguns postulados sobre a plasticidade do neocórtex em geral, que relacionam a consolidação de memórias explícitas ao ciclo sono-vigília. Sintetizando tais postulados: (1) No início da aprendizagem, os aspectos multimodais da experiência sensorial seriam codificados por interações instáveis envolvendo a formação hipocampal, córtices rinais e o resto do neocórtex, sustentando memórias de prazo curto. Eventualmente, as interações mais relevantes ou mantidas por repetição fortaleceriam as redes corticocorticais envolvidas, ora pela reforma de conexões intracorticais prévias, ora pela criação de conexões novas. Finalmente, no gradual desengajamento das interações hipocampocorticais e concomitante estabelecimento de novos padrões funcionais e morfológicos intracorticais, a experiência se consolidaria como uma memória duradoura (Frankland e Bontempi, 2005 ${ }^{333}$ ). (2) A consolidação de memórias explícitas ocorreria em etapas sucessivas, alternando períodos favoráveis ao fluxo de informações hipocampocorticais com períodos de remodelagem funcional e morfológica dentro de módulos neocorticais específicos. A alternância cíclica entre estas duas etapas estaria alicerçada nos estados oscilatórios do sono de ondas lentas (fluxo de informações entre formação hipocampal e neocórtex) e sono paradoxal (consolidação intracortical; Diekelmann e Born, 2010 ; Born e Wilhelm, 2012 ${ }^{334}$ ). (3) O fluxo de informações hipocampocorticais seria representado por salvas de potenciais de ação em altíssimas frequências ( 100-300 Hz) temporalmente acopladas às ondas delta e ondas em fuso geradas pelo sistema talamocortical no sono de ondas lentas. Tais salvas induziriam os mecanismos não-morfológicos de plasticidade sináptica, dependentes da concentração citossólica de $\mathrm{Ca}^{2+}$ e mobilização de receptores, principalmente na densidade pós-sináptica de espinhos dendríticos. Dependendo da sinalização intracelular dependente de $\mathrm{Ca}^{2+}$, as sinapses intracorticais ganhariam mais ou menos probabilidade de sofrer as alterações morfológicas no sono paradoxal, completando o processo de consolidação mnemônica (Ribeiro e Nicolelis, $2004^{335}$ ). (4) De acordo com a hipótese de que o sono serviria como regulador homeostático da plasticidade sináptica (Tononi e Cirelli, $2003^{336}$ ), o sono de ondas lentas deprimiria a função sináptica ao longo do neocórtex, preparando-o para a vigília 
seguinte. Neste contexto de despotencialização generalizada, a potencialização de vias hipocampocorticais particulares seria destacada. Isto priorizaria as sinapses neocorticais a serem estruturalmente modificadas durante os episódios subsequentes de sono paradoxal (Ribeiro e Nicolelis, $2004^{335}$ ).

Conjuntamente, os postulados defendem que a arquitetura do sono serviria como substrato fisiológico às etapas da consolidação de memórias explícitas. Este contexto fisiológico, executado pelo sistema talamocortical, afeta a comunicação hipocampocortical. A interação triangular entre hipocampo, tálamo e neocórtex provavelmente inclui o circuito formado por CA1/subículo, CPF e Tmd. Futuros estudos que monitorem, simultaneamente, a plasticidade pré-frontal induzida a partir de aferências centrípetas poderão confirmar ou refutar nossas ideias. Isto esclarecerá a relação entre a consolidação de memórias e os estágios do sono, especificamente no que diz respeito às memórias processadas pelo CPF, por exemplo contingências estímulo-resposta e sequências comportamentais. Alternativamente, talvez a plasticidade pré-frontal modulada pelo sono não seja, necessariamente, atrelada à consolidação de memórias. Ao invés disto, é possível que esta plasticidade seja mais importante à restauração funcional do CPF, que otimizaria o controle atentivo e pré-motor na vigília. De qualquer forma, transtornos neuropsiquiátricos dependentes do CPF podem ter várias relações bidirecionais com os distúrbios do sono, cujos sintomas cognitivos podem ser explicados pela disfunção pré-frontal. Isto sugere a necessidade de maior exploração da rede límbica convergente ao CPF com e sem anestesia, em busca de achados com relevância diretamente clínica. 
7. CONSIDERAÇÕES FINAIS 
O trânsito entre o ponto de vista molecular e o panorâmico é um exercício necessário ao progresso interdisciplinar. Isto desafia o neurocientista a lidar com uma gama de procedimentos experimentais e comunicativos não necessariamente pertencentes à sua formação básica. A diversidade de nichos, em suas variadas interseções, inclui biologia molecular, farmácia, eletrofisiologia, observação comportamental, e as análises matemáticas que procuram dar coesão a estes cenários.

A tentativa de contextualizar os processos corticais em meio à sua modulação aferente é particularmente acolhedora a este trânsito entre abordagens. No caso das redes límbicas, o esforço integrador esclarecerá cada vez mais as cooperações subjacentes à cognição saudável, subsidiando a busca por novas estratégias clínicas. Nossos estudos tentam decifrar uma parte destas cooperações em rede: a interação de entradas talâmicas e hipocampais no córtex pré-frontal, e sua plasticidade conforme a regulação colinérgica. Esperamos contribuir ao entendimento das funções executivas durante o alerta e sono paradoxal, destacando que a reverberação excitatória do córtex pré-frontal junto ao tálamo tem sido pouco explorada no Brasil. 


\section{REFERÊNCIAS}


1. Nieuwenhuys R. The neocortex. An overview of its evolutionary development, structural organization and synaptology. Anat Embryol. 1994 Oct;190(4):307-37.

2. Braitenberg V. Thoughts on the cerebral cortex. J Theor Biol. 1974 Aug;46(2):421-47.

3. Schüz A, Chaimow D, Liewald D, Dortenman M. Quantitative aspects of corticocortical connections: a tracer study in the mouse. Cereb Cortex. 2006 Oct;16(10):1474-86.

4. Okhotin VE. Cytophysiology of spiny stellate cells in the striate cortex and their role in the excitatory mechanisms of intracortical synaptic circulation. Neurosci Behav Physiol. 2006 Oct;36(8):825-36.

5. Kätzel D, Zemelman BV, Buetfering C, Wölfel M, Miesenböck G. The columnar and laminar organization of inhibitory connections to neocortical excitatory cells. Nat Neurosci. 2011 Jan;14(1):100-7.

6. Gu Q. Neuromodulatory transmitter systems in the cortex and their role in cortical plasticity. Neuroscience. 2002;111(4):815-35.

7. Castro-Alamancos MA, Connors BW. Thalamocortical synapses. Prog Neurobiol. 1997 Apr;51(6):581-606.

8. Diekelmann S, Born J. The memory function of sleep. Nat Rev Neurosci. 2010 Feb;11(2):114-26.

9. Harris KD, Thiele A. Cortical state and attention. Nat Rev Neurosci. 2011 Sep;12(9):50923.

10. Steriade M, McCormick DA, Sejnowski TJ. Thalamocortical oscillations in the sleeping and aroused brain. Science. 1993 Oct 29;262(5134):679-85.

11. Amitai Y. Thalamocortical synaptic connections: efficacy, modulation, inhibition and plasticity. Rev Neurosci. 2001;12(2):159-73.

12. Cronenwett WJ, Csernansky J. Thalamic pathology in schizophrenia. Curr Top Behav Neurosci. 2010;4:509-28.

13. Sherman SM, Guillery RW. Exploring the thalamus. San Diego: Academic Press; 2001.

14. Jones EG. Thalamic organization and function after Cajal. Prog Brain Res. 2002;136:33357.

15. Price DJ, Kennedy H, Dehay C, Zhou L, Mercier M, Jossin Y, et al. The development of cortical connections. Eur J Neurosci. 2006 Feb;23(4):910-20.

16. Bentivoglio M, Spreafico R, Minciacchi D, Macchi G. GABAergic interneurons and neuropil of the intralaminar thalamus: an immunohistochemical study in the rat and the cat, with notes in the monkey. Exp Brain Res. 1991;87(1):85-95. 
17. Arcelli P, Frassoni C, Regondi MC, De Biasi S, Spreafico R. GABAergic neurons in mammalian thalamus: a marker of thalamic complexity? Brain Res Bull. 1997;42(1):2737.

18. Pinault D. The thalamic reticular nucleus: structure, function and concept. Brain Res Brain Res Rev. 2004 Aug;46(1):1-31.

19. Ramón y Cajal S. Texture of the nervous system of man and the vertebrates. Volume II. New York: Springer; 2000.

20. Ramón y Cajal S. Texture of the nervous system of man and the vertebrates. Volume III. New York: Springer; 2002.

21. Nissl F. Die Grosshirnanteile des Kaninchens. Eur Arch Psychiatry Clin Neurosci. 1913;52(3):867-953.

22. Lorente de Nó R. Architectonics and structure of the cerebral cortex. The physiology of the nervous system. London: Oxford University Press; 1938. p. 291-340.

23. Herkenham M. Laminar organization of thalamic projections to the rat neocortex. Science. 1980 Feb 1;207(4430):532-5.

24. Van der Werf YD, Witter MP, Groenewegen HJ. The intralaminar and midline nuclei of the thalamus. Anatomical and functional evidence for participation in processes of arousal and awareness. Brain Res Brain Res Rev. 2002 Sep;39(2-3):107-40.

25. Hayano Y, Yamamoto N. Activity-dependent thalamocortical axon branching. The Neuroscientist. 2008 Aug 1;14(4):359-68.

26. Feldman DE, Nicoll RA, Malenka RC. Synaptic plasticity at thalamocortical synapses in developing rat somatosensory cortex: LTP, LTD, and silent synapses. J Neurobiol. 1999 Oct;41(1):92-101.

27. Heynen AJ, Bear MF. Long-term potentiation of thalamocortical transmission in the adult visual cortex in vivo. J Neurosci. 2001 Dec 15;21(24):9801-13.

28. Gagolewicz PJ, Dringenberg HC. NR2B-subunit dependent facilitation of long-term potentiation in primary visual cortex following visual discrimination training of adult rats. Eur J Neurosci. 2011 Oct;34(8):1222-9.

29. Dringenberg HC, Hamze B, Wilson A, Speechley W, Kuo M-C. Heterosynaptic facilitation of in vivo thalamocortical long-term potentiation in the adult rat visual cortex by acetylcholine. Cereb Cortex. 2007 Apr;17(4):839-48.

30. Kuo M-C, Dringenberg HC. Histamine facilitates in vivo thalamocortical long-term potentiation in the mature visual cortex of anesthetized rats. Eur J Neurosci. 2008 Apr;27(7):1731-8. 
31. Kuo M-C, Rasmusson DD, Dringenberg HC. Input-selective potentiation and rebalancing of primary sensory cortex afferents by endogenous acetylcholine. Neuroscience. 2009 Sep 29;163(1):430-41.

32. Hogsden JL, Rosen LG, Dringenberg HC. Pharmacological and deprivation-induced reinstatement of juvenile-like long-term potentiation in the primary auditory cortex of adult rats. Neuroscience. 2011 Jul 14;186:208-19.

33. Blundon JA, Bayazitov IT, Zakharenko SS. Presynaptic gating of postsynaptically expressed plasticity at mature thalamocortical synapses. J Neurosci. $2011 \mathrm{Nov}$ 2;31(44):16012-25.

34. Colonnier M, Guillery RW. Synaptic organization in the lateral geniculate nucleus of the monkey. Z Zellforsch Mikrosk Anat. 1964 Apr 9;62:333-55.

35. Guillery RW. The organization of synaptic interconnections in the laminae of the dorsal lateral geniculate nucleus of the cat. Z Zellforsch Mikrosk Anat. 1969;96(1):1-38.

36. Van Horn SC, Erişir A, Sherman SM. Relative distribution of synapses in the A-laminae of the lateral geniculate nucleus of the cat. J Comp Neurol. 2000 Jan 24;416(4):509-20.

37. Sherman SM, Guillery RW. The role of the thalamus in the flow of information to the cortex. Philos Trans R Soc Lond B Biol Sci. 2002 Dec 29;357(1428):1695-708.

38. Sherman SM, Guillery RW. On the actions that one nerve cell can have on another: distinguishing "drivers" from "modulators."Proc Natl Acad Sci USA. 1998 Jun 9;95(12):7121-6.

39. Sommer MA. The role of the thalamus in motor control. Curr Opin Neurobiol. 2003 Dec;13(6):663-70.

40. Sommer MA, Wurtz RH. Brain circuits for the internal monitoring of movements. Annu Rev Neurosci. 2008;31:317-38.

41. Llinás RR, Steriade M. Bursting of thalamic neurons and states of vigilance. J Neurophysiol. 2006 Jun;95(6):3297-308.

42. Jahnsen $\mathrm{H}$, Llinás R. Electrophysiological properties of guinea-pig thalamic neurones: an in vitro study. J Physiol. 1984 Apr;349:205-26.

43. Jahnsen $\mathrm{H}$, Llinás $\mathrm{R}$. Ionic basis for the electro-responsiveness and oscillatory properties of guinea-pig thalamic neurones in vitro. J Physiol. 1984 Apr;349:227-47.

44. Deschênes $M$, Roy JP, Steriade $M$. Thalamic bursting mechanism: an inward slow current revealed by membrane hyperpolarization. Brain Res. 1982 May 6;239(1):289-93.

45. Deschênes $M$, Paradis $M$, Roy JP, Steriade M. Electrophysiology of neurons of lateral thalamic nuclei in cat: resting properties and burst discharges. J Neurophysiol. 1984 Jun;51(6):1196-219. 
46. Butler AB. Evolution of brains, cognition, and consciousness. Brain Res Bull. 2008 Mar $18 ; 75(2-4): 442-9$.

47. Rial RV, Akaârir M, Gamundí A, Nicolau C, Garau C, Aparicio S, et al. Evolution of wakefulness, sleep and hibernation: from reptiles to mammals. Neurosci Biobehav Rev. 2010 Jul;34(8):1144-60.

48. Domich L, Oakson G, Steriade M. Thalamic burst patterns in the naturally sleeping cat: a comparison between cortically projecting and reticularis neurones. J Physiol (Lond). 1986 Oct;379:429-49.

49. McCormick DA, Pape HC. Properties of a hyperpolarization-activated cation current and its role in rhythmic oscillation in thalamic relay neurones. J Physiol (Lond). 1990 Dec;431:291-318.

50. Coulter DA, Huguenard JR, Prince DA. Calcium currents in rat thalamocortical relay neurones: kinetic properties of the transient, low-threshold current. J Physiol (Lond). 1989 Jul;414:587-604.

51. Steriade M, Deschenes M. The thalamus as a neuronal oscillator. Brain Res. 1984 Nov;320(1):1-63.

52. Steriade M, Domich L, Oakson G. Reticularis thalami neurons revisited: activity changes during shifts in states of vigilance. J Neurosci. 1986 Jan;6(1):68-81.

53. Steriade M, Domich L, Oakson G, Deschênes $M$. The deafferented reticular thalamic nucleus generates spindle rhythmicity. J Neurophysiol. 1987 Jan;57(1):260-73.

54. McCormick DA. Neurotransmitter actions in the thalamus and cerebral cortex and their role in neuromodulation of thalamocortical activity. Prog Neurobiol. 1992 Oct;39(4):337-88.

55. Sherman SM. A wake-up call from the thalamus. Nat Neurosci. 2001 Apr;4(4):344-6.

56. Lisman JE. Bursts as a unit of neural information: making unreliable synapses reliable. Trends Neurosci. 1997 Jan;20(1):38-43.

57. Swadlow HA, Gusev AG. The impact of "bursting" thalamic impulses at a neocortical synapse. Nat Neurosci. 2001 Apr;4(4):402-8.

58. Paré D, Llinás R. Conscious and pre-conscious processes as seen from the standpoint of sleep-waking cycle neurophysiology. Neuropsychologia. 1995 Sep;33(9):1155-68.

59. Losier BJ, Semba K. Dual projections of single cholinergic and aminergic brainstem neurons to the thalamus and basal forebrain in the rat. Brain Res. 1993 Feb 26;604(12):41-52.

60. Lucas-Meunier E, Fossier P, Baux G, Amar M. Cholinergic modulation of the cortical neuronal network. Pflugers Arch. 2003 Apr;446(1):17-29. 
61. Steriade M. Acetylcholine systems and rhythmic activities during the waking--sleep cycle. Prog Brain Res. 2004;145:179-96.

62. Parent M, Descarries L. Acetylcholine innervation of the adult rat thalamus: distribution and ultrastructural features in dorsolateral geniculate, parafascicular, and reticular thalamic nuclei. J Comp Neurol. 2008 Dec 10;511(5):678-91.

63. Barbier AJ, Bradbury MJ. Histaminergic control of sleep-wake cycles: recent therapeutic advances for sleep and wake disorders. CNS Neurol Disord Drug Targets. 2007 Feb;6(1):31-43.

64. Berridge CW, Waterhouse BD. The locus coeruleus-noradrenergic system: modulation of behavioral state and state-dependent cognitive processes. Brain Res Brain Res Rev. 2003 Apr;42(1):33-84.

65. Monti JM. The role of dorsal raphe nucleus serotonergic and non-serotonergic neurons, and of their receptors, in regulating waking and rapid eye movement (REM) sleep. Sleep Med Rev. 2010 Oct;14(5):319-27.

66. Monti JM, Monti D. The involvement of dopamine in the modulation of sleep and waking. Sleep Med Rev. 2007 Apr;11(2):113-33.

67. Llinás R, Urbano FJ, Leznik E, Ramírez RR, van Marle HJF. Rhythmic and dysrhythmic thalamocortical dynamics: GABA systems and the edge effect. Trends Neurosci. 2005 Jun;28(6):325-33.

68. Swerdlow NR. Integrative circuit models and their implications for the pathophysiologies and treatments of the schizophrenias. Curr Top Behav Neurosci. 2010;4:555-83.

69. Sukhodolsky DG, Leckman JF, Rothenberger A, Scahill L. The role of abnormal neural oscillations in the pathophysiology of co-occurring Tourette syndrome and attentiondeficit/hyperactivity disorder. Eur Child Adolesc Psychiatry. 2007 Jun;16 Suppl 1:51-9.

70. Vukadinovic Z. Sleep abnormalities in schizophrenia may suggest impaired transthalamic cortico-cortical communication: towards a dynamic model of the illness. Eur J Neurosci. 2011 Oct;34(7):1031-9.

71. Bertram EH. Temporal lobe epilepsy: where do the seizures really begin? Epilepsy Behav. 2009 Jan;14 Suppl 1:32-7.

72. Bertram EH, Zhang DX, Mangan P, Fountain N, Rempe D. Functional anatomy of limbic epilepsy: a proposal for central synchronization of a diffusely hyperexcitable network. Epilepsy Res. 1998 Sep;32(1-2):194-205.

73. Kandratavicius L, Lopes-Aguiar C, Bueno-Júnior L, Romcy-Pereira R, Hallak J, Leite J. Psychiatric comorbidities in temporal lobe epilepsy: possible relationships between psychotic disorders and involvement of limbic circuits. Rev Bras Psiquiatr. 2012; in press.

74. Schmahmann JD. Vascular syndromes of the thalamus. Stroke. 2003 Sep;34(9):2264-78. 
75. Hübener M. Mouse visual cortex. Curr Opin Neurobiol. 2003 Aug;13(4):413-20.

76. Petersen $\mathrm{CCH}$. The functional organization of the barrel cortex. Neuron. 2007 Oct 25;56(2):339-55.

77. Otani S. Prefrontal cortex from synaptic plasticity to cognition. Boston: Kluwer Academic Publishers; 2004.

78. Dalley JW, Cardinal RN, Robbins TW. Prefrontal executive and cognitive functions in rodents: neural and neurochemical substrates. Neurosci Biobehav Rev. 2004 Nov;28(7):771-84.

79. Stamm JS, Weber-Levine ML. Delayed alternation impairments following selective prefrontal cortical ablations in monkeys. Exp Neurol. 1971 Nov;33(2):263-78.

80. Stamm JS. The monkey's prefrontal cortex functions in motor programming. Acta Neurobiol Exp (Wars). 1979;39(6):683-704.

81. Kojima S, Goldman-Rakic PS. Delay-related activity of prefrontal neurons in rhesus monkeys performing delayed response. Brain Res. 1982 Sep 23;248(1):43-9.

82. Goldman-Rakic PS. Cellular and circuit basis of working memory in prefrontal cortex of nonhuman primates. Prog Brain Res. 1990;85:325-335; discussion 335-336.

83. Kubota K, Niki H. Prefrontal cortical unit activity and delayed alternation performance in monkeys. J Neurophysiol. 1971 May;34(3):337-47.

84. Kubota K, Tonoike M, Mikami A. Neuronal activity in the monkey dorsolateral prefrontal cortex during a discrimination task with delay. Brain Res. 1980 Feb 3;183(1):29-42.

85. Niki H, Watanabe M. Prefrontal and cingulate unit activity during timing behavior in the monkey. Brain Res. 1979 Aug 3;171(2):213-24.

86. Watanabe M. Prefrontal unit activity during delayed conditional discriminations in the monkey. Brain Res. 1981 Nov 23;225(1):51-65.

87. Fuster JM. Unit activity in prefrontal cortex during delayed-response performance: neuronal correlates of transient memory. J Neurophysiol. 1973 Jan;36(1):61-78.

88. Bauer RH, Fuster JM. Effects of d-amphetamine and prefrontal cortical cooling on delayed matching-to-sample behavior. Pharmacol Biochem Behav. 1978 Mar;8(3):243-9.

89. Funahashi S. Responses of monkey prefrontal neurons during a visual tracking task reinforced by substantia innominata self-stimulation. Brain Res. 1983 Oct 16;276(2):26776.

90. Funahashi S, Bruce CJ, Goldman-Rakic PS. Mnemonic coding of visual space in the monkey's dorsolateral prefrontal cortex. J Neurophysiol. 1989 Feb;61(2):331-49. 
91. Kolb B. Dissociation of the effects of lesions of the orbital or medial aspect of the prefrontal cortex of the rat with respect to activity. Behav Biol. 1974 Mar;10(3):329-43.

92. Kolb B. Social behavior of rats with chronic prefrontal lesions. J Comp Physiol Psychol. 1974 Sep;87(3):466-74.

93. Mora F, Myers RD. Brain self-stimulation: direct evidence for the involvement of dopamine in the prefrontal cortex. Science. 1977 Sep 30;197(4311):1387-9.

94. Mora F. The neurochemical substrates of prefrontal cortex self-stimulation: a review and an interpretation of some recent data. Life Sci. 1978 Mar;22(11):919-29.

95. Kesner RP, Holbrook T. Dissociation of item and order spatial memory in rats following medial prefrontal cortex lesions. Neuropsychologia. 1987;25(4):653-64.

96. Kesner RP. Retrospective and prospective coding of information: role of the medial prefrontal cortex. Exp Brain Res. 1989;74(1):163-7.

97. Uylings HBM, Groenewegen HJ, Kolb B. Do rats have a prefrontal cortex? Behav Brain Res. 2003 Nov 30;146(1-2):3-17.

98. Rose J, Woolsey C. The orbitofrontal cortex and its connections with the mediodorsal nucleus in rabbit, sheep and cat. Res Publ Assoc Res Nerv Ment Dis. 1948;27:210-32.

99. Groenewegen HJ, Berendse HW. The specificity of the "nonspecific" midline and intralaminar thalamic nuclei. Trends Neurosci. 1994 Feb;17(2):52-7.

100. Asunción Morán M, Reinoso-Suárez F. Topographical organization of the thalamic afferent connections to the motor cortex in the cat. J Comp Neurol. $1988 \mathrm{Apr}$ 1;270(1):64-85.

101. Giguere M, Goldman-Rakic PS. Mediodorsal nucleus: areal, laminar, and tangential distribution of afferents and efferents in the frontal lobe of rhesus monkeys. J Comp Neurol. 1988 Nov 8;277(2):195-213.

102. Kessler J, Markowitsch HJ. Delayed-alternation performance after kainic acid lesions of the thalamic mediodorsal nucleus and the ventral tegmental area in the rat. Behav Brain Res. 1981 Jul;3(1):125-30.

103. Markowitsch HJ, Kessler J, Streicher M. Consequences of serial cortical, hippocampal, and thalamic lesions and of different lengths of overtraining on the acquisition and retention of learning tasks. Behav Neurosci. 1985 Apr;99(2):233-56.

104. Harrison LM, Mair RG. A comparison of the effects of frontal cortical and thalamic lesions on measures of spatial learning and memory in the rat. Behav Brain Res. 1996 Feb;75(1-2):195-206.

105. Bailey KR, Mair RG. Lesions of specific and nonspecific thalamic nuclei affect prefrontal cortex-dependent aspects of spatial working memory. Behav Neurosci. 2005 Apr;119(2):410-9. 
106. Romanides AJ, Duffy P, Kalivas PW. Glutamatergic and dopaminergic afferents to the prefrontal cortex regulate spatial working memory in rats. Neuroscience. 1999;92(1):97106.

107. Churchill L, Zahm DS, Duffy P, Kalivas PW. The mediodorsal nucleus of the thalamus in rats--II. Behavioral and neurochemical effects of GABA agonists. Neuroscience. 1996 Jan;70(1):103-12.

108. Chauveau F, Piérard C, Corio M, Célérier A, Christophe T, Vouimba RM, et al. Mediodorsal thalamic lesions block the stress-induced inversion of serial memory retrieval pattern in mice. Behav Brain Res. 2009 Nov 5;203(2):270-8.

109. Block AE, Dhanji H, Thompson-Tardif SF, Floresco SB. Thalamic-prefrontal corticalventral striatal circuitry mediates dissociable components of strategy set shifting. Cereb Cortex. 2007 Jul;17(7):1625-36.

110. Antoniadis EA, McDonald RJ. Fornix, medial prefrontal cortex, nucleus accumbens, and mediodorsal thalamic nucleus: roles in a fear-based context discrimination task. Neurobiol Learn Mem. 2006 Jan;85(1):71-85.

111. Padilla-Coreano N, Do-Monte FH, Quirk GJ. A time-dependent role of midline thalamic nuclei in the retrieval of fear memory. Neuropharmacology. 2012 Jan;62(1):457-63.

112. Young KA, Hicks PB, Randall PK, Wilcox RE. Behavioral and frontal cortical metabolic effects of apomorphine and muscimol microinjections into the mediodorsal thalamic nucleus. J Neural Transm Gen Sect. 1994;98(2):119-32.

113. Vives F, Morales A, Mora F. Lesions of connections of the medial prefrontal cortex in rats: differential effects on self-stimulation and spontaneous motor activity. Physiol Behav. 1986 Jan;36(1):47-52.

114. Ferrer JM, Cobo M, Mora F. The basolateral limbic circuit and self-stimulation of the medial prefrontal cortex in the rat. Physiol Behav. 1987;40(3):291-5.

115. Sarter M, Bodewitz G, Steckler T. 2-[3H]deoxyglucose uptake patterns in rats exploring a six-arm radial tunnel maze: differences between experienced and nonexperienced rats. Behav Neurosci. 1989 Dec;103(6):1217-25.

116. Gabriel M, Orona E. Parallel and serial processes of the prefrontal and cingulate cortical systems during behavioral learning. Brain Res Bull. 1982 Jun;8(6):781-5.

117. Oyoshi T, Nishijo H, Asakura T, Takamura Y, Ono T. Emotional and behavioral correlates of mediodorsal thalamic neurons during associative learning in rats. J Neurosci. 1996 Sep 15;16(18):5812-29.

118. Hoover WB, Vertes RP. Anatomical analysis of afferent projections to the medial prefrontal cortex in the rat. Brain Struct Funct. 2007 Sep;212(2):149-79. 
119. Paxinos G, Watson C. The rat brain in stereotaxic coordinates. Amsterdam; Boston: Elsevier; 2007.

120. Vertes RP. Interactions among the medial prefrontal cortex, hippocampus and midline thalamus in emotional and cognitive processing in the rat. Neuroscience. 2006 Sep 29;142(1):1-20.

121. Ferron A, Thierry AM, Le Douarin C, Glowinski J. Inhibitory influence of the mesocortical dopaminergic system on spontaneous activity or excitatory response induced from the thalamic mediodorsal nucleus in the rat medial prefrontal cortex. Brain Res. 1984 Jun 8;302(2):257-65.

122. Mantz J, Milla C, Glowinski J, Thierry AM. Differential effects of ascending neurons containing dopamine and noradrenaline in the control of spontaneous activity and of evoked responses in the rat prefrontal cortex. Neuroscience. 1988 Nov;27(2):517-26.

123. Mantz J, Godbout R, Tassin JP, Glowinski J, Thierry AM. Inhibition of spontaneous and evoked unit activity in the rat medial prefrontal cortex by mesencephalic raphe nuclei. Brain Res. 1990 Jul 30;524(1):22-30.

124. Pirot S, Jay TM, Glowinski J, Thierry AM. Anatomical and electrophysiological evidence for an excitatory amino acid pathway from the thalamic mediodorsal nucleus to the prefrontal cortex in the rat. Eur J Neurosci. 1994 Jul 1;6(7):1225-34.

125. Pirot S, Glowinski J, Thierry AM. Excitatory responses evoked in prefrontal cortex by mediodorsal thalamic nucleus stimulation: influence of anaesthesia. Eur J Pharmacol. 1995 Oct 4;285(1):45-54.

126. Pirot S, Glowinski J, Thierry AM. Mediodorsal thalamic evoked responses in the rat prefrontal cortex: influence of the mesocortical DA system. Neuroreport. 1996 May $31 ; 7(8): 1437-41$.

127. Gioanni Y, Rougeot C, Clarke PB, Lepousé C, Thierry AM, Vidal C. Nicotinic receptors in the rat prefrontal cortex: increase in glutamate release and facilitation of mediodorsal thalamo-cortical transmission. Eur J Neurosci. 1999 Jan;11(1):18-30.

128. Krettek JE, Price JL. The cortical projections of the mediodorsal nucleus and adjacent thalamic nuclei in the rat. J Comp Neurol. 1977 Jan 15;171(2):157-91.

129. Kuroda M, Yokofujita J, Murakami K. An ultrastructural study of the neural circuit between the prefrontal cortex and the mediodorsal nucleus of the thalamus. Prog Neurobiol. 1998 Mar;54(4):417-58.

130. Beckstead RM. An autoradiographic examination of corticocortical and subcortical projections of the mediodorsal-projection (prefrontal) cortex in the rat. J Comp Neurol. 1979 Mar 1;184(1):43-62.

131. Hebb DO. The organization of behavior : a neuropsychological theory. Mahwah, NJ: L. Erlbaum Associates; 2002. 
132. Bliss TV, Gardner-Medwin AR. Long-lasting potentiation of synaptic transmission in the dentate area of the unanaestetized rabbit following stimulation of the perforant path. J Physiol (Lond). 1973 Jul;232(2):357-74.

133. Bliss TV, Lomo T. Long-lasting potentiation of synaptic transmission in the dentate area of the anaesthetized rabbit following stimulation of the perforant path. J Physiol (Lond). 1973 Jul;232(2):331-56.

134. Andersen P, Morris R, Amaral D, Bliss T, O'Keefe J. The Hippocampus book. Oxford: Oxford University Press; 2007.

135. Tsumoto T. Long-term potentiation and long-term depression in the neocortex. Prog Neurobiol. 1992 Aug;39(2):209-28.

136. Bliss TV, Collingridge GL. A synaptic model of memory: long-term potentiation in the hippocampus. Nature. 1993 Jan 7;361(6407):31-9.

137. Abraham WC, Goddard GV. Asymmetric relationships between homosynaptic longterm potentiation and heterosynaptic long-term depression. Nature. 1983 Oct 20;305(5936):717-9.

138. Ekerot CF, Kano M. Long-term depression of parallel fibre synapses following stimulation of climbing fibres. Brain Res. 1985 Sep 9;342(2):357-60.

139. Martin SJ, Morris RGM. New life in an old idea: the synaptic plasticity and memory hypothesis revisited. Hippocampus. 2002;12(5):609-36.

140. Citri A, Malenka RC. Synaptic plasticity: multiple forms, functions, and mechanisms. Neuropsychopharmacology. 2008 Jan;33(1):18-41.

141. Mathis DM, Furman JL, Norris CM. Preparation of Acute Hippocampal Slices from Rats and Transgenic Mice for the Study of Synaptic Alterations during Aging and Amyloid Pathology. J Vis Exp. 2011 Mar 23;(49):e2330.

142. Lu HC, Gonzalez E, Crair MC. Barrel cortex critical period plasticity is independent of changes in NMDA receptor subunit composition. Neuron. 2001 Nov 20;32(4):619-34.

143. Daw MI, Scott HL, Isaac JTR. Developmental synaptic plasticity at the thalamocortical input to barrel cortex: mechanisms and roles. Mol Cell Neurosci. 2007 Apr;34(4):493502.

144. Scott HL, Braud S, Bannister NJ, Isaac JTR. Synaptic strength at the thalamocortical input to layer IV neonatal barrel cortex is regulated by protein kinase $\mathrm{C}$.

Neuropharmacology. 2007 Jan;52(1):185-92.

145. Hogsden JL, Dringenberg HC. Decline of long-term potentiation (LTP) in the rat auditory cortex in vivo during postnatal life: involvement of NR2B subunits. Brain Res. 2009 Aug 4;1283:25-33. 
146. Speechley WJ, Hogsden JL, Dringenberg HC. Continuous white noise exposure during and after auditory critical period differentially alters bidirectional thalamocortical plasticity in rat auditory cortex in vivo. Eur J Neurosci. 2007 Nov;26(9):2576-84.

147. Kuo M-C, Dringenberg HC. Short-term (2 to $5 \mathrm{~h}$ ) dark exposure lowers long-term potentiation (LTP) induction threshold in rat primary visual cortex. Brain Res. 2009 Jun 18;1276:58-66.

148. Hager AM, Dringenberg HC. Assessment of different induction protocols to elicit long-term depression (LTD) in the rat visual cortex in vivo. Brain Res. 2010 Mar 8;1318:33-41.

149. Herry C, Vouimba RM, Garcia R. Plasticity in the mediodorsal thalamo-prefrontal cortical transmission in behaving mice. J Neurophysiol. 1999 Nov;82(5):2827-32.

150. Herry C, Garcia R. Prefrontal cortex long-term potentiation, but not long-term depression, is associated with the maintenance of extinction of learned fear in mice. J Neurosci. 2002 Jan 15;22(2):577-83.

151. Bremner JD, Narayan M, Staib LH, Southwick SM, McGlashan T, Charney DS. Neural correlates of memories of childhood sexual abuse in women with and without posttraumatic stress disorder. Am J Psychiatry. 1999 Nov;156(11):1787-95.

152. Bremner JD, Staib LH, Kaloupek D, Southwick SM, Soufer R, Charney DS. Neural correlates of exposure to traumatic pictures and sound in Vietnam combat veterans with and without posttraumatic stress disorder: a positron emission tomography study. Biol Psychiatry. 1999 Apr 1;45(7):806-16.

153. Fernandez $M$, Pissiota A, Frans O, von Knorring L, Fischer $H$, Fredrikson M. Brain function in a patient with torture related post-traumatic stress disorder before and after fluoxetine treatment: a positron emission tomography provocation study. Neurosci Lett. 2001 Jan 12;297(2):101-4.

154. de Zubicaray GI, McMahon K, Wilson SJ, Muthiah S. Brain activity during the encoding, retention, and retrieval of stimulus representations. Learn Mem. 2001 Oct;8(5):243-51.

155. Monchi O, Petrides M, Petre V, Worsley K, Dagher A. Wisconsin Card Sorting revisited: distinct neural circuits participating in different stages of the task identified by event-related functional magnetic resonance imaging. J Neurosci. 2001 Oct 1;21(19):7733-41.

156. Simó LS, Krisky CM, Sweeney JA. Functional neuroanatomy of anticipatory behavior: dissociation between sensory-driven and memory-driven systems. Cereb Cortex. 2005 Dec;15(12):1982-91.

157. Buchsbaum MS, Buchsbaum BR, Chokron S, Tang C, Wei T-C, Byne W. Thalamocortical circuits: $\mathrm{fMRI}$ assessment of the pulvinar and medial dorsal nucleus in normal volunteers. Neurosci Lett. 2006 Sep 1;404(3):282-7. 
158. Mitelman SA, Byne W, Kemether EM, Newmark RE, Hazlett EA, Haznedar MM, et al. Metabolic thalamocortical correlations during a verbal learning task and their comparison with correlations among regional volumes. Brain Res. 2006 Oct 9;1114(1):125-37.

159. Parris BA, Thai NJ, Benattayallah A, Summers IR, Hodgson TL. The role of the lateral prefrontal cortex and anterior cingulate in stimulus-response association reversals. J Cogn Neurosci. 2007 Jan;19(1):13-24.

160. Zoppelt D, Koch B, Schwarz M, Daum I. Involvement of the mediodorsal thalamic nucleus in mediating recollection and familiarity. Neuropsychologia. 2003;41(9):116070 .

161. Pakkenberg B. Leucotomized schizophrenics lose neurons in the mediodorsal thalamic nucleus. Neuropathol Appl Neurobiol. 1993 Oct;19(5):373-80.

162. Young KA, Manaye KF, Liang C, Hicks PB, German DC. Reduced number of mediodorsal and anterior thalamic neurons in schizophrenia. Biol Psychiatry. 2000 Jun 1;47(11):944-53.

163. Steiner J, Bielau H, Brisch R, Danos P, Ullrich O, Mawrin C, et al. Immunological aspects in the neurobiology of suicide: elevated microglial density in schizophrenia and depression is associated with suicide. J Psychiatr Res. 2008 Jan;42(2):151-7.

164. Lewis DA, Cruz DA, Melchitzky DS, Pierri JN. Lamina-specific deficits in parvalbuminimmunoreactive varicosities in the prefrontal cortex of subjects with schizophrenia: evidence for fewer projections from the thalamus. Am J Psychiatry. 2001 Sep;158(9):1411-22.

165. Thune JJ, Uylings HB, Pakkenberg B. No deficit in total number of neurons in the prefrontal cortex in schizophrenics. J Psychiatr Res. 2001 Feb;35(1):15-21.

166. Popken GJ, Bunney WE Jr, Potkin SG, Jones EG. Subnucleus-specific loss of neurons in medial thalamus of schizophrenics. Proc Natl Acad Sci USA. 2000 Aug 1;97(16):9276-80.

167. Hazlett EA, Buchsbaum MS, Byne W, Wei TC, Spiegel-Cohen J, Geneve C, et al. Threedimensional analysis with MRI and PET of the size, shape, and function of the thalamus in the schizophrenia spectrum. Am J Psychiatry. 1999 Aug;156(8):1190-9.

168. Ananth H, Popescu I, Critchley HD, Good CD, Frackowiak RSJ, Dolan RJ. Cortical and subcortical gray matter abnormalities in schizophrenia determined through structural magnetic resonance imaging with optimized volumetric voxel-based morphometry. Am J Psychiatry. 2002 Sep;159(9):1497-505.

169. Klein JC, Rushworth MFS, Behrens TEJ, Mackay CE, de Crespigny AJ, D'Arceuil H, et al. Topography of connections between human prefrontal cortex and mediodorsal thalamus studied with diffusion tractography. Neuroimage. 2010 Jun;51(2):555-64. 
170. Kim D-J, Kim J-J, Park JY, Lee SY, Kim J, Kim IY, et al. Quantification of thalamocortical tracts in schizophrenia on probabilistic maps. Neuroreport. 2008 Mar 5;19(4):399-403.

171. Kito S, Jung J, Kobayashi T, Koga Y. Fiber tracking of white matter integrity connecting the mediodorsal nucleus of the thalamus and the prefrontal cortex in schizophrenia: a diffusion tensor imaging study. Eur Psychiatry. 2009 Jun;24(5):269-74.

172. Hazlett EA, Buchsbaum MS, Zhang J, Newmark RE, Glanton CF, Zelmanova Y, et al. Frontal-striatal-thalamic mediodorsal nucleus dysfunction in schizophrenia-spectrum patients during sensorimotor gating. Neuroimage. 2008 Sep 1;42(3):1164-77.

173. Young KA, Holcomb LA, Yazdani U, Hicks PB, German DC. Elevated neuron number in the limbic thalamus in major depression. Am J Psychiatry. 2004 Jul;161(7):1270-7.

174. Cardoso EF, Maia FM, Fregni F, Myczkowski ML, Melo LM, Sato JR, et al. Depression in Parkinson's disease: convergence from voxel-based morphometry and functional magnetic resonance imaging in the limbic thalamus. Neuroimage. 2009 Aug $15 ; 47(2): 467-72$.

175. Nakamura M, Uchida S, Maehara T, Kawai K, Hirai N, Nakabayashi T, et al. Sleep spindles in human prefrontal cortex: an electrocorticographic study. Neurosci Res. 2003 Apr;45(4):419-27.

176. Li X, Nahas Z, Kozel FA, Anderson B, Bohning DE, George MS. Acute left prefrontal transcranial magnetic stimulation in depressed patients is associated with immediately increased activity in prefrontal cortical as well as subcortical regions. Biol Psychiatry. 2004 May 1;55(9):882-90.

177. Bertram EH, Scott C. The pathological substrate of limbic epilepsy: neuronal loss in the medial dorsal thalamic nucleus as the consistent change. Epilepsia. 2000;41 Suppl 6:S3-8.

178. Bertram EH, Mangan PS, Zhang D, Scott CA, Williamson JM. The midline thalamus: alterations and a potential role in limbic epilepsy. Epilepsia. 2001 Aug;42(8):967-78.

179. Rajasekaran K, Kapur J, Bertram EH. Alterations in GABA(A) receptor mediated inhibition in adjacent dorsal midline thalamic nuclei in a rat model of chronic limbic epilepsy. J. Neurophysiol. 2007 Nov;98(5):2501-8.

180. Bertram EH, Zhang D, Williamson JM. Multiple roles of midline dorsal thalamic nuclei in induction and spread of limbic seizures. Epilepsia. 2008 Feb;49(2):256-68.

181. Sloan DM, Bertram EH 3rd. Changes in midline thalamic recruiting responses in the prefrontal cortex of the rat during the development of chronic limbic seizures. Epilepsia. 2009 Mar;50(3):556-65.

182. Rajasekaran K, Sun C, Bertram EH. Altered pharmacology and GABA-A receptor subunit expression in dorsal midline thalamic neurons in limbic epilepsy. Neurobiol Dis. 2009 Jan;33(1):119-32. 
183. Sloan DM, Zhang D, Bertram EH 3rd. Increased GABAergic inhibition in the midline thalamus affects signaling and seizure spread in the hippocampus-prefrontal cortex pathway. Epilepsia. 2011 Mar;52(3):523-30.

184. Sloan DM, Zhang D, Bertram EH 3rd. Excitatory amplification through divergentconvergent circuits: the role of the midline thalamus in limbic seizures. Neurobiol Dis. 2011 Aug;43(2):435-45.

185. Tansey EM. Henry Dale and the discovery of acetylcholine. Comptes Rendus Biologies. 2006 May;329(5-6):419-25.

186. Deutsch JA. The cholinergic synapse and the site of memory. Science. 1971 Nov 19;174(4011):788-94.

187. Drachman DA. Memory and cognitive function in man: does the cholinergic system have a specific role? Neurology. 1977 Aug;27(8):783-90.

188. Hasselmo ME, Sarter M. Modes and models of forebrain cholinergic neuromodulation of cognition. Neuropsychopharmacology. 2011 Jan;36(1):52-73.

189. Rodda J, Morgan S, Walker Z. Are cholinesterase inhibitors effective in the management of the behavioral and psychological symptoms of dementia in Alzheimer's disease? A systematic review of randomized, placebo-controlled trials of donepezil, rivastigmine and galantamine. Int Psychogeriatr. 2009 Oct;21(5):813-24.

190. Klinkenberg I, Blokland A. The validity of scopolamine as a pharmacological model for cognitive impairment: a review of animal behavioral studies. Neurosci Biobehav Rev. $2010 \mathrm{Jul} ; 34(8): 1307-50$.

191. Lancaster T, Stead LF. Mecamylamine (a nicotine antagonist) for smoking cessation. Cochrane Database Syst Rev. 2000;(2):CD001009.

192. Sandhu S, Abreu I, Colombo C, Mazzafera P. Pilocarpine content and molecular diversity in Jaborandi. Scientia Agric. 2006 Sep;63(5):478-82.

193. Sawaya ACHF, Vaz BG, Eberlin MN, Mazzafera P. Screening species of Pilocarpus (Rutaceae) as sources of pilocarpine and other imidazole alkaloids. Gen Resour Crop Evol. 2011 Jan 29;58(3):471-80.

194. Lee DA, Higginbotham EJ. Glaucoma and its treatment: a review. Am J Health Syst Pharm. 2005 Apr 1;62(7):691-9.

195. Berk L. Systemic pilocarpine for treatment of xerostomia. Expert Opin Drug Metab Toxicol. 2008 Oct;4(10):1333-40.

196. Turski L, Ikonomidou C, Turski WA, Bortolotto ZA, Cavalheiro EA. Review: cholinergic mechanisms and epileptogenesis. The seizures induced by pilocarpine: a novel experimental model of intractable epilepsy. Synapse. 1989;3(2):154-71. 
197. Cavalheiro EA. The pilocarpine model of epilepsy. Ital J Neurol Sci. 1995 Mar;16(12):33-7.

198. Leite JP, Garcia-Cairasco N, Cavalheiro EA. New insights from the use of pilocarpine and kainate models. Epilepsy Res. 2002 Jun;50(1-2):93-103.

199. Haas LF. Jean Nicot 1530-1600. J Neurol Neurosurg Psychiatry. 1992 Jun 1;55(6):430430.

200. Miwa JM, Freedman R, Lester HA. Neural systems governed by nicotinic acetylcholine receptors: emerging hypotheses. Neuron. 2011 Apr 14;70(1):20-33.

201. Herman Al, Sofuoglu M. Cognitive effects of nicotine: genetic moderators. Addict Biol. 2010 Jul;15(3):250-65.

202. De Biasi M, Dani JA. Reward, addiction, withdrawal to nicotine. Annu Rev Neurosci. 2011;34:105-30.

203. Kenney JW, Gould TJ. Modulation of hippocampus-dependent learning and synaptic plasticity by nicotine. Mol Neurobiol. 2008 Aug;38(1):101-21.

204. O'Dell LE. A psychobiological framework of the substrates that mediate nicotine use during adolescence. Neuropharmacology. 2009;56 Suppl 1:263-78.

205. Lajtha A, Sershen H. Nicotine: alcohol reward interactions. Neurochem Res. 2010 Aug;35(8):1248-58.

206. Mobascher A, Winterer G. The molecular and cellular neurobiology of nicotine abuse in schizophrenia. Pharmacopsychiatry. 2008 Sep;41 Suppl 1:S51-59.

207. Quik M, Huang LZ, Parameswaran N, Bordia T, Campos C, Perez XA. Multiple roles for nicotine in Parkinson's disease. Biochem Pharmacol. 2009 Oct 1;78(7):677-85.

208. King $\mathrm{H}$. The isolation of muscarine, the potent principle of Amanita muscaria. J Chem Soc. $1922 ; 121: 1743-53$.

209. Purves D. Neuroscience. Sunderland: Sinauer Associates; 2004.

210. Nathanson NM. Synthesis, trafficking, and localization of muscarinic acetylcholine receptors. Pharmacol Ther. 2008 Jul;119(1):33-43.

211. Ishii M, Kurachi Y. Muscarinic acetylcholine receptors. Curr Pharm Des. 2006;12(28):3573-81.

212. Carr DB, Surmeier DJ. M1 muscarinic receptor modulation of Kir2 channels enhances temporal summation of excitatory synaptic potentials in prefrontal cortex pyramidal neurons. J Neurophysiol. 2007 May;97(5):3432-8. 
213. Stanfield PR, Nakajima S, Nakajima Y. Constitutively active and G-protein coupled inward rectifier K+ channels: Kir2.0 and Kir3.0. Rev Physiol Biochem Pharmacol. 2002;145:47-179.

214. Wang L, Yuan L-L. Activation of M2 muscarinic receptors leads to sustained suppression of hippocampal transmission in the medial prefrontal cortex. J Physiol. 2009 Sep 14;587(21):5139-47.

215. Levey Al. Immunological localization of $\mathrm{m} 1-\mathrm{m} 5$ muscarinic acetylcholine receptors in peripheral tissues and brain. Life Sci. 1993;52(5-6):441-8.

216. Rouse ST, Edmunds SM, Yi H, Gilmor ML, Levey Al. Localization of $M(2)$ muscarinic acetylcholine receptor protein in cholinergic and non-cholinergic terminals in rat hippocampus. Neurosci Lett. 2000 Apr 28;284(3):182-6.

217. Leach K, Simms J, Sexton PM, Christopoulos A. Structure-function studies of muscarinic acetylcholine receptors. Handb Exp Pharmacol. 2012;(208):29-48.

218. Hoss W, Woodruff JM, Ellerbrock BR, Periyasamy S, Ghodsi-Hovsepian S, Stibbe J, et al. Biochemical and behavioral responses of pilocarpine at muscarinic receptor subtypes in the CNS. Comparison with receptor binding and low-energy conformations. Brain Res. 1990 Nov 19;533(2):232-8.

219. Maslanski JA, Powelt R, Deirmengiant C, Patelt J. Assessment of the muscarinic receptor subtypes involved in pilocarpine-induced seizures in mice. Neurosci Lett. 1994 Feb 28;168(1-2):225-8.

220. Mayorga AJ, Cousins MS, Trevitt JT, Conlan A, Gianutsos G, Salamone JD. Characterization of the muscarinic receptor subtype mediating pilocarpine-induced tremulous jaw movements in rats. Eur J Pharmacol. 1999 Jan 1;364(1):7-11.

221. Bymaster FP, Carter PA, Yamada M, Gomeza J, Wess J, Hamilton SE, et al. Role of specific muscarinic receptor subtypes in cholinergic parasympathomimetic responses, in vivo phosphoinositide hydrolysis, and pilocarpine-induced seizure activity. Eur J Neurosci. 2003 Apr;17(7):1403-10.

222. Wirtshafter $D$. The selective $m 1$ muscarinic antagonist MT-7 blocks pilocarpineinduced striatal Fos expression. Brain Res. 2006 Apr 26;1085(1):127-31.

223. Dani JA, Bertrand D. Nicotinic acetylcholine receptors and nicotinic cholinergic mechanisms of the central nervous system. Annu Rev Pharmacol Toxicol. 2007;47:699729.

224. D’hoedt D, Bertrand D. Nicotinic acetylcholine receptors: an overview on drug discovery. Expert Opin Ther Targets. 2009 Apr;13(4):395-411.

225. Flores CM, Rogers SW, Pabreza LA, Wolfe BB, Kellar KJ. A subtype of nicotinic cholinergic receptor in rat brain is composed of alpha 4 and beta 2 subunits and is upregulated by chronic nicotine treatment. Mol Pharmacol. 1992 Jan;41(1):31-7. 
226. Vernino S, Amador M, Luetje CW, Patrick J, Dani JA. Calcium modulation and high calcium permeability of neuronal nicotinic acetylcholine receptors. Neuron. 1992 Jan;8(1):127-34.

227. Happe HK, Peters JL, Bergman DA, Murrin LC. Localization of nicotinic cholinergic receptors in rat brain: autoradiographic studies with [3H]cytisine. Neuroscience. 1994 Oct;62(3):929-44.

228. Nashmi R, Lester HA. CNS localization of neuronal nicotinic receptors. J Mol Neurosci. 2006;30(1-2):181-4.

229. Zhou F-M, Wilson CJ, Dani JA. Cholinergic interneuron characteristics and nicotinic properties in the striatum. J Neurobiol. 2002 Dec;53(4):590-605.

230. Hasselmo ME, Giocomo LM. Cholinergic modulation of cortical function. J Mol Neurosci. 2006;30(1-2):133-5.

231. Parikh V, Sarter M. Cholinergic mediation of attention: contributions of phasic and tonic increases in prefrontal cholinergic activity. Ann NY Acad Sci. 2008;1129:225-35.

232. Sarter M, Parikh V, Howe WM. Phasic acetylcholine release and the volume transmission hypothesis: time to move on. Nat Rev Neurosci. 2009 May;10(5):383-90.

233. Semba K. The cholinergic basal forebrain: a critical role in cortical arousal. Adv Exp Med Biol. 1991;295:197-218.

234. Schliebs R. Basal forebrain cholinergic dysfunction in Alzheimer's disease-interrelationship with beta-amyloid, inflammation and neurotrophin signaling. Neurochem Res. 2005 Jul;30(6-7):895-908.

235. Auld DS, Kornecook TJ, Bastianetto S, Quirion R. Alzheimer's disease and the basal forebrain cholinergic system: relations to beta-amyloid peptides, cognition, and treatment strategies. Prog Neurobiol. 2002 Oct;68(3):209-45.

236. Bohnen NI, Albin RL. The cholinergic system and Parkinson disease. Behav Brain Res. 2011 Aug 10;221(2):564-73.

237. Friedman Jl. Cholinergic targets for cognitive enhancement in schizophrenia: focus on cholinesterase inhibitors and muscarinic agonists. Psychopharmacology (Berl). 2004 Jun;174(1):45-53.

238. Terry AV Jr, Mahadik SP. Time-dependent cognitive deficits associated with first and second generation antipsychotics: cholinergic dysregulation as a potential mechanism. J Pharmacol Exp Ther. 2007 Mar;320(3):961-8.

239. Scarr E, Dean B. Role of the cholinergic system in the pathology and treatment of schizophrenia. Expert Rev Neurother. 2009 Jan;9(1):73-86.

240. McCarley RW. Neurobiology of REM and NREM sleep. Sleep Med. 2007 Jun;8(4):30230. 
241. Stenberg D. Neuroanatomy and neurochemistry of sleep. Cell Mol Life Sci. 2007 May;64(10):1187-204.

242. Curró Dossi R, Paré D, Steriade M. Short-lasting nicotinic and long-lasting muscarinic depolarizing responses of thalamocortical neurons to stimulation of mesopontine cholinergic nuclei. J Neurophysiol. 1991 Mar;65(3):393-406.

243. Urbano FJ, Kezunovic N, Hyde J, Simon C, Beck P, Garcia-Rill E. Gamma band activity in the reticular activating system. Front Neurol. 2012;3:6.

244. Pal D, Mallick BN. Neural mechanism of rapid eye movement sleep generation with reference to REM-OFF neurons in locus coeruleus. Indian J Med Res. 2007 Jun;125(6):721-39.

245. Adamantidis A, Carter MC, de Lecea L. Optogenetic deconstruction of sleep-wake circuitry in the brain. Front Mol Neurosci. 2010;2:31.

246. Détári L, Semba K, Rasmusson DD. Responses of cortical EEG-related basal forebrain neurons to brainstem and sensory stimulation in urethane-anaesthetized rats. Eur J Neurosci. 1997 Jun;9(6):1153-61.

247. Boucetta S, Jones BE. Activity profiles of cholinergic and intermingled GABAergic and putative glutamatergic neurons in the pontomesencephalic tegmentum of urethaneanesthetized rats. J Neurosci. 2009 Apr 8;29(14):4664-74.

248. Maggi CA, Meli A. Suitability of urethane anesthesia for physiopharmacological investigations in various systems. Part 1: General considerations. Experientia. 1986 Feb 15;42(2):109-14.

249. Dringenberg HC, Olmstead MC. Integrated contributions of basal forebrain and thalamus to neocortical activation elicited by pedunculopontine tegmental stimulation in urethane-anesthetized rats. Neuroscience. 2003;119(3):839-53.

250. Clement EA, Richard A, Thwaites M, Ailon J, Peters S, Dickson CT. Cyclic and sleep-like spontaneous alternations of brain state under urethane anaesthesia. PLOS ONE. 2008;3(4):e2004.

251. Hara K, Harris RA. The anesthetic mechanism of urethane: the effects on neurotransmitter-gated ion channels. Anesth Analg. 2002 Feb;94(2):313-318, table of contents.

252. Horner RL, Kubin L. Pontine carbachol elicits multiple rapid eye movement sleep-like neural events in urethane-anaesthetized rats. Neuroscience. 1999;93(1):215-26.

253. Balatoni B, Détári L. EEG related neuronal activity in the pedunculopontine tegmental nucleus of urethane anaesthetized rats. Brain Res. 2003 Jan 10;959(2):304-11.

254. Toth A, Hajnik T, Detari L. Cholinergic modulation of slow cortical rhythm in urethane-anesthetized rats. Brain Res Bull. 2012 Jan 4;87(1):117-29. 
255. Swanson LW. A direct projection from Ammon's horn to prefrontal cortex in the rat. Brain Res. 1981 Jul 27;217(1):150-4.

256. Ferino F, Thierry AM, Glowinski J. Anatomical and electrophysiological evidence for a direct projection from Ammon's horn to the medial prefrontal cortex in the rat. Exp Brain Res. 1987;65(2):421-6.

257. Laroche S, Jay TM, Thierry AM. Long-term potentiation in the prefrontal cortex following stimulation of the hippocampal CA1/subicular region. Neurosci Lett. 1990 Jul 3;114(2):184-90.

258. Laroche S, Davis S, Jay TM. Plasticity at hippocampal to prefrontal cortex synapses: dual roles in working memory and consolidation. Hippocampus. 2000;10(4):438-46.

259. Takita M, Izaki Y, Jay TM, Kaneko H, Suzuki SS. Induction of stable long-term depression in vivo in the hippocampal-prefrontal cortex pathway. Eur J Neurosci. 1999 Nov;11(11):4145-8.

260. Jay TM, Burette F, Laroche S. NMDA receptor-dependent long-term potentiation in the hippocampal afferent fibre system to the prefrontal cortex in the rat. Eur J Neurosci. 1995 Feb 1;7(2):247-50.

261. Lopes-Aguiar C, Bueno-Júnior L, Ruggiero R, Romcy-Pereira R, Leite J. NMDA receptor blockade impairs the muscarinic conversion of sub-threshold transient depression into long-lasting LTD in the hippocampus-prefrontal cortex pathway in vivo: correlation with gamma oscillations. Neuropharmacology. 2013;65:143-155.

262. Rocher C, Spedding M, Munoz C, Jay TM. Acute stress-induced changes in hippocampal/prefrontal circuits in rats: effects of antidepressants. Cereb Cortex. 2004 Feb;14(2):224-9.

263. Kessal K, Deschaux O, Chessel A, Xu L, Moreau J-L, Garcia R. Fluoxetine reverses stress-induced fimbria-prefrontal long-term potentiation facilitation. Neuroreport. 2006 Feb 27;17(3):319-22.

264. Goto Y, Yang CR, Otani S. Functional and dysfunctional synaptic plasticity in prefrontal cortex: roles in psychiatric disorders. Biol Psychiatry. 2010 Feb 1;67(3):199207.

265. Romcy-Pereira R, Pavlides C. Distinct modulatory effects of sleep on the maintenance of hippocampal and medial prefrontal cortex LTP. Eur J Neurosci. 2004 Dec;20(12):345362.

266. Lopes Aguiar C, Romcy-Pereira RN, Escorsim Szawka R, Galvis-Alonso OY, AnselmoFranci JA, Pereira Leite J. Muscarinic acetylcholine neurotransmission enhances the latephase of long-term potentiation in the hippocampal-prefrontal cortex pathway of rats in vivo: a possible involvement of monoaminergic systems. Neuroscience. 2008 Jun 2;153(4):1309-19. 
267. Ruggiero RN, Lopes-Aguiar C, Bueno Júnior LS, Leite JP, Romcy-Pereira RN. Lithium effects and interactions with the muscarinic neurotransmission on synaptic plasticity in the medial prefrontal cortex of rats in vivo. San Diego, CA; 2010.

268. Herry C, Garcia R. Behavioral and paired-pulse facilitation analyses of long-lasting depression at excitatory synapses in the medial prefrontal cortex in mice. Behav Brain Res. 2003 Nov 30;146(1-2):89-96.

269. Hugues S, Garcia R. Reorganization of learning-associated prefrontal synaptic plasticity between the recall of recent and remote fear extinction memory. Learn Mem. 2007 Aug;14(8):520-4.

270. Gigg J, Tan AM, Finch DM. Glutamatergic hippocampal formation projections to prefrontal cortex in the rat are regulated by GABAergic inhibition and show convergence with glutamatergic projections from the limbic thalamus. Hippocampus. 1994 Apr;4(2):189-98.

271. Groenewegen $\mathrm{HJ}$, Wright $\mathrm{Cl}$, Uylings $\mathrm{HB}$. The anatomical relationships of the prefrontal cortex with limbic structures and the basal ganglia. J Psychopharmacol (Oxford). 1997;11(2):99-106.

272. Floresco SB, Grace AA. Gating of hippocampal-evoked activity in prefrontal cortical neurons by inputs from the mediodorsal thalamus and ventral tegmental area. $J$ Neurosci. 2003 May 1;23(9):3930-43.

273. Rotaru DC, Barrionuevo G, Sesack SR. Mediodorsal thalamic afferents to layer III of the rat prefrontal cortex: synaptic relationships to subclasses of interneurons. J Comp Neurol. 2005 Sep 26;490(3):220-38.

274. Leung LS. Generation of theta and gamma rhythms in the hippocampus. Neurosci Biobehav Rev. 1998 Mar;22(2):275-90.

275. Lubenov EV, Siapas AG. Hippocampal theta oscillations are travelling waves. Nature. 2009 May 28;459(7246):534-9.

276. Schaeppi U. Nicotine treatment of selected areas of the cat brain: effects upon EEG and autonomic system. Int J Neuropharmacol. 1968 May;7(3):207-20.

277. Guha D, Pradhan SN. Effects of nicotine on EEG and evoked potentials and their interactions with autonomic drugs. Neuropharmacology. 1976 Apr;15(4):225-32.

278. Haranath PS, Venkatakrishna-Bhatt H. Sleep induced by drugs injected into the inferior horn of the lateral cerebral ventricle in dogs. Br J Pharmacol. 1977 Feb;59(2):231-6.

279. Martin WR, Sloan JW, Hook R, Kaplan E, Wash C. Fourth ventricle effects of nicotine, 2-methylpiperidine and cytisine in dogs. Pharmacol Biochem Behav. 1986 Oct;25(4):8438. 
280. Zucker RS, Regehr WG. Short-term synaptic plasticity. Annu Rev Physiol. 2002;64:355-405.

281. Otani S. Prefrontal cortex function, quasi-physiological stimuli, and synaptic plasticity. J Physiol Paris. 2003 Nov;97(4-6):423-30.

282. Maroun M, Richter-Levin G. Exposure to acute stress blocks the induction of longterm potentiation of the amygdala-prefrontal cortex pathway in vivo. J Neurosci. 2003 Jun 1;23(11):4406-9.

283. Richter-Levin G, Maroun M. Stress and amygdala suppression of metaplasticity in the medial prefrontal cortex. Cereb Cortex. 2010 Oct;20(10):2433-41.

284. Ohashi S, Matsumoto M, Otani H, Mori K, Togashi H, Ueno K, et al. Changes in synaptic plasticity in the rat hippocampo-medial prefrontal cortex pathway induced by repeated treatments with fluvoxamine. Brain Res. 2002 Sep 13;949(1-2):131-8.

285. Ohashi S, Matsumoto M, Togashi H, Ueno K, Yoshioka M. The serotonergic modulation of synaptic plasticity in the rat hippocampo-medial prefrontal cortex pathway. Neurosci Lett. 2003 May 22;342(3):179-82.

286. Ishikawa A, Kadota T, Kadota K, Matsumura H, Nakamura S. Essential role of D1 but not $D 2$ receptors in methamphetamine-induced impairment of long-term potentiation in hippocampal-prefrontal cortex pathway. Eur J Neurosci. 2005 Oct;22(7):1713-9.

287. Otani S, Blond O, Desce JM, Crépel F. Dopamine facilitates long-term depression of glutamatergic transmission in rat prefrontal cortex. Neuroscience. 1998 Aug;85(3):66976.

288. Young CE, Yang CR. Dopamine D1-like receptor modulates layer- and frequencyspecific short-term synaptic plasticity in rat prefrontal cortical neurons. Eur J Neurosci. 2005 Jun;21(12):3310-20.

289. Matsuda Y, Marzo A, Otani S. The presence of background dopamine signal converts long-term synaptic depression to potentiation in rat prefrontal cortex. J Neurosci. 2006 May 3;26(18):4803-10.

290. Kolomiets B, Marzo A, Caboche J, Vanhoutte P, Otani S. Background dopamine concentration dependently facilitates long-term potentiation in rat prefrontal cortex through postsynaptic activation of extracellular signal-regulated kinases. Cereb. Cortex. 2009 Nov;19(11):2708-18.

291. Jay TM, Witter MP. Distribution of hippocampal CA1 and subicular efferents in the prefrontal cortex of the rat studied by means of anterograde transport of Phaseolus vulgaris-leucoagglutinin. J Comp Neurol. 1991 Nov 22;313(4):574-86.

292. Müller W, Connor JA. Ca2+ signalling in postsynaptic dendrites and spines of mammalian neurons in brain slice. J Physiol Paris. 1992;86(1-3):57-66. 
293. Huerta PT, Lisman JE. Bidirectional synaptic plasticity induced by a single burst during cholinergic theta oscillation in CA1 in vitro. Neuron. 1995 Nov;15(5):1053-63.

294. Dragunow M, Abraham W, Hughes P. Activation of NMDA and muscarinic receptors induces nur-77 mRNA in hippocampal neurons. Brain Res Mol Brain Res. 1996 Mar;36(2):349-56.

295. Choi S-Y, Chang J, Jiang B, Seol G-H, Min S-S, Han J-S, et al. Multiple receptors coupled to phospholipase $C$ gate long-term depression in visual cortex. J Neurosci. 2005 Dec 7;25(49):11433-43.

296. Hasselmo ME, Barkai E. Cholinergic modulation of activity-dependent synaptic plasticity in the piriform cortex and associative memory function in a network biophysical simulation. J Neurosci. 1995 Oct;15(10):6592-604.

297. Jones MW, French PJ, Bliss TV, Rosenblum K. Molecular mechanisms of long-term potentiation in the insular cortex in vivo. J Neurosci. 1999 Nov 1;19(21):RC36.

298. Gu Q. Contribution of acetylcholine to visual cortex plasticity. Neurobiol Learn Mem. 2003 Nov;80(3):291-301.

299. Fernández de Sevilla D, Núñez A, Borde M, Malinow R, Buño W. Cholinergic-mediated IP3-receptor activation induces long-lasting synaptic enhancement in CA1 pyramidal neurons. J Neurosci. 2008 Feb 6;28(6):1469-78.

300. Scheiderer CL, Smith CC, McCutchen E, McCoy PA, Thacker EE, Kolasa K, et al. Coactivation of $\mathrm{M}(1)$ muscarinic and alpha1 adrenergic receptors stimulates extracellular signal-regulated protein kinase and induces long-term depression at CA3-CA1 synapses in rat hippocampus. J Neurosci. 2008 May 14;28(20):5350-8.

301. Bartlett TE, Lu J, Wang YT. Slice orientation and muscarinic acetylcholine receptor activation determine the involvement of $\mathrm{N}$-methyl $\mathrm{D}$-aspartate receptor subunit GluN2B in hippocampal area CA1 long-term depression. Mol Brain. 2011;4:41.

302. Petrovic MM, Nowacki J, Olivo V, Tsaneva-Atanasova K, Randall AD, Mellor JR. Inhibition of post-synaptic Kv7/KCNQ/M channels facilitates long-term potentiation in the hippocampus. PLoS ONE. 2012;7(2):e30402.

303. Shor OL, Fidzinski P, Behr J. Muscarinic acetylcholine receptors and voltage-gated calcium channels contribute to bidirectional synaptic plasticity at CA1-subiculum synapses. Neurosci Lett. 2009 Jan 16;449(3):220-3.

304. Silkis I. The cortico-basal ganglia-thalamocortical circuit with synaptic plasticity. I. Modification rules for excitatory and inhibitory synapses in the striatum. BioSystems. 2000 Sep;57(3):187-96.

305. Wang Y, Greig NH, Yu Q, Mattson MP. Presenilin-1 mutation impairs cholinergic modulation of synaptic plasticity and suppresses NMDA currents in hippocampus slices. Neurobiol Aging. 2009 Jul;30(7):1061-8. 
306. Ondrejcak T, Klyubin I, Hu N-W, Barry AE, Cullen WK, Rowan MJ. Alzheimer's disease amyloid beta-protein and synaptic function. Neuromolecular Med. 2010 Mar;12(1):1326.

307. Bröcher S, Artola A, Singer W. Agonists of cholinergic and noradrenergic receptors facilitate synergistically the induction of long-term potentiation in slices of rat visual cortex. Brain Res. 1992 Feb 21;573(1):27-36.

308. Boroojerdi B, Battaglia F, Muellbacher W, Cohen LG. Mechanisms underlying rapid experience-dependent plasticity in the human visual cortex. Proc Natl Acad Sci USA. 2001 Dec 4;98(25):14698-701.

309. Kang Jl, Vaucher E. Cholinergic pairing with visual activation results in long-term enhancement of visual evoked potentials. PLoS ONE. 2009;4(6):e5995.

310. Placzek AN, Zhang TA, Dani JA. Age dependent nicotinic influences over dopamine neuron synaptic plasticity. Biochem Pharmacol. 2009 Oct 1;78(7):686-92.

311. Verhoog MB, Mansvelder HD. Presynaptic ionotropic receptors controlling and modulating the rules for spike timing-dependent plasticity. Neural Plast.

2011;2011:870763.

312. Mao D, Gallagher K, McGehee DS. Nicotine potentiation of excitatory inputs to ventral tegmental area dopamine neurons. J Neurosci. 2011 May 4;31(18):6710-20.

313. Nishizaki T, Nomura T, Matsuoka T, Enikolopov G, Sumikawa K. Arachidonic acid induces a long-lasting facilitation of hippocampal synaptic transmission by modulating PKC activity and nicotinic ACh receptors. Brain Res Mol Brain Res. 1999 Jun 8;69(2):26372.

314. Mann EO, Greenfield SA. Novel modulatory mechanisms revealed by the sustained application of nicotine in the guinea-pig hippocampus in vitro. J Physiol (Lond). 2003 Sep 1;551(Pt 2):539-50.

315. Maggi L, Sola E, Minneci F, Le Magueresse C, Changeux JP, Cherubini E. Persistent decrease in synaptic efficacy induced by nicotine at Schaffer collateral-CA1 synapses in the immature rat hippocampus. J Physiol (Lond). 2004 Sep 15;559(Pt 3):863-74.

316. Broide RS, Leslie FM. The alpha7 nicotinic acetylcholine receptor in neuronal plasticity. Mol Neurobiol. 1999 Aug;20(1):1-16.

317. Fayuk D, Yakel JL. Ca2+ permeability of nicotinic acetylcholine receptors in rat hippocampal CA1 interneurones. J Physiol (Lond). 2005 Aug 1;566(Pt 3):759-68.

318. Wang H-L, Chen X-T, Luo L, Lou Z-Y, Wang S, Chen J-T, et al. Reparatory effects of nicotine on NMDA receptor-mediated synaptic plasticity in the hippocampal CA1 region of chronically lead-exposed rats. Eur J Neurosci. 2006 Mar;23(5):1111-9. 
319. Hornick A, Lieb A, Vo NP, Rollinger JM, Stuppner H, Prast H. The coumarin scopoletin potentiates acetylcholine release from synaptosomes, amplifies hippocampal long-term potentiation and ameliorates anticholinergic- and age-impaired memory. Neuroscience. 2011 Dec 1;197:280-92.

320. Gao M, Jin Y, Yang K, Zhang D, Lukas RJ, Wu J. Mechanisms involved in systemic nicotine-induced glutamatergic synaptic plasticity on dopamine neurons in the ventral tegmental area. J Neurosci. 2010 Oct 13;30(41):13814-25.

321. Livingstone PD, Dickinson JA, Srinivasan J, Kew JNC, Wonnacott S. Glutamatedopamine crosstalk in the rat prefrontal cortex is modulated by Alpha7 nicotinic receptors and potentiated by PNU-120596. J Mol Neurosci. 2010 Jan;40(1-2):172-6.

322. Jin $\mathrm{Y}$, Yang $\mathrm{K}$, Wang $\mathrm{H}, \mathrm{Wu}$ J. Exposure of nicotine to ventral tegmental area slices induces glutamatergic synaptic plasticity on dopamine neurons. Synapse. 2011 Apr;65(4):332-8.

323. Snyder EM, Nong Y, Almeida CG, Paul S, Moran T, Choi EY, et al. Regulation of NMDA receptor trafficking by amyloid-beta. Nat Neurosci. 2005 Aug;8(8):1051-8.

324. Wei W, Nguyen LN, Kessels HW, Hagiwara H, Sisodia S, Malinow R. Amyloid beta from axons and dendrites reduces local spine number and plasticity. Nat Neurosci. 2010 Feb;13(2):190-6.

325. Jerusalinsky D, Kornisiuk E, Izquierdo I. Cholinergic neurotransmission and synaptic plasticity concerning memory processing. Neurochem Res. 1997 Apr;22(4):507-15.

326. Jo J, Son GH, Winters BL, Kim MJ, Whitcomb DJ, Dickinson BA, et al. Muscarinic receptors induce LTD of NMDAR EPSCs via a mechanism involving hippocalcin, AP2 and PSD-95. Nat Neurosci. 2010 Oct;13(10):1216-24.

327. Mansvelder HD, Mertz M, Role LW. Nicotinic modulation of synaptic transmission and plasticity in cortico-limbic circuits. Semin Cell Dev Biol. 2009 Jun;20(4):432-40.

328. Lin H, Vicini S, Hsu F-C, Doshi S, Takano H, Coulter DA, et al. Axonal $\alpha 7$ nicotinic ACh receptors modulate presynaptic NMDA receptor expression and structural plasticity of glutamatergic presynaptic boutons. Proc Natl Acad Sci USA. 2010 Sep 21;107(38):166616.

329. Chee MWL, Choo WC. Functional imaging of working memory after $24 \mathrm{hr}$ of total sleep deprivation. J Neurosci. 2004 May 12;24(19):4560-7.

330. Szelenberger W, Piotrowski T, Dabrowska AJ. Increased prefrontal event-related current density after sleep deprivation. Acta Neurobiol Exp (Wars). 2005;65(1):19-28.

331. Ferreira C, Deslandes A, Moraes H, Cagy M, Basile LF, Piedade R, et al. The relation between EEG prefrontal asymmetry and subjective feelings of mood following 24 hours of sleep deprivation. Arq Neuropsiquiatr. 2006 Jun;64(2B):382-7. 
332. Soshi T, Kuriyama K, Aritake S, Enomoto M, Hida A, Tamura M, et al. Sleep deprivation influences diurnal variation of human time perception with prefrontal activity change: a functional near-infrared spectroscopy study. PLoS ONE. 2010;5(1):e8395.

333. Frankland PW, Bontempi B. The organization of recent and remote memories. Nat Rev Neurosci. 2005 Feb;6(2):119-30.

334. Born J, Wilhelm I. System consolidation of memory during sleep. Psychol Res. 2012 Mar;76(2):192-203.

335. Ribeiro S, Nicolelis MAL. Reverberation, storage, and postsynaptic propagation of memories during sleep. Learn Mem. 2004 Dec;11(6):686-96.

336. Tononi G, Cirelli C. Sleep and synaptic homeostasis: a hypothesis. Brain Res Bull. 2003 Dec 15;62(2):143-50. 
ANEXO: ARTIGO PRINCIPAL [PLOS ONE 2012;7(10):E47484] 


\title{
Muscarinic and Nicotinic Modulation of Thalamo- Prefrontal Cortex Synaptic Pasticity In Vivo
}

\author{
Lezio Soares Bueno-Junior ${ }^{1}$, Cleiton Lopes-Aguiar ${ }^{1}$, Rafael Naime Ruggiero ${ }^{1}$, Rodrigo Neves Romcy- \\ Pereira $^{1,2 *}$, João Pereira Leite ${ }^{1}$
}

1 Department of Neuroscience and Behavioral Sciences, Ribeirão Preto School of Medicine, University of São Paulo, Ribeirão Preto, São Paulo, Brazil, 2 Brain Institute, Federal University of Rio Grande do Norte, Natal, Rio Grande do Norte, Brazil

\begin{abstract}
The mediodorsal nucleus of the thalamus (MD) is a rich source of afferents to the medial prefrontal cortex (mPFC). Dysfunctions in the thalamo-prefrontal connections can impair networks implicated in working memory, some of which are affected in Alzheimer disease and schizophrenia. Considering the importance of the cholinergic system to cortical functioning, our study aimed to investigate the effects of global cholinergic activation of the brain on MD-mPFC synaptic plasticity by measuring the dynamics of long-term potentiation (LTP) and depression (LTD) in vivo. Therefore, rats received intraventricular injections either of the muscarinic agonist pilocarpine (PILO; $40 \mathrm{nmol} / \mu \mathrm{L}$ ), the nicotinic agonist nicotine (NIC; $320 \mathrm{nmol} / \mu \mathrm{L}$ ), or vehicle. The injections were administered prior to either thalamic high-frequency (HFS) or low-frequency stimulation (LFS). Test pulses were applied to MD for 30 min during baseline and 240 min after HFS or LFS, while field postsynaptic potentials were recorded in the MPFC. The transient oscillatory effects of PILO and NIC were monitored through recording of thalamic and cortical local field potentials. Our results show that HFS did not affect mPFC responses in vehicle-injected rats, but induced a delayed-onset LTP with distinct effects when applied following PILO or NIC. Conversely, LFS induced a stable LTD in control subjects, but was unable to induce LTD when applied after PILO or NIC. Taken together, our findings show distinct modulatory effects of each cholinergic brain activation on MD-mPFC plasticity following HFS and LFS. The LTP-inducing action and long-lasting suppression of cortical LTD induced by PILO and NIC might implicate differential modulation of thalamo-prefrontal functions under low and high input drive.
\end{abstract}

Citation: Bueno-Junior LS, Lopes-Aguiar C, Ruggiero RN, Romcy-Pereira RN, Leite JP (2012) Muscarinic and Nicotinic Modulation of Thalamo-Prefrontal Cortex Synaptic Pasticity In Vivo. PLoS ONE 7(10): e47484. doi:10.1371/journal.pone.0047484

Editor: Michelle L. Block, Virginia Commonwealth University, United States of America

Received May 9, 2012; Accepted September 11, 2012; Published October 30, 2012

Copyright: (c) 2012 Bueno-Junior et al. This is an open-access article distributed under the terms of the Creative Commons Attribution License, which permits unrestricted use, distribution, and reproduction in any medium, provided the original author and source are credited.

Funding: This work was supported by grants from FAPESP (\#2008/57413-7), FAPESP-CInAPCe (\#2005/56447-7) and CNPq (\#502726/2009-1). Respectively, these are the funder's websites: http://www.fapesp.br/en/, http://www.fcm.unicamp.br/cinapce/, http://www.cnpq.br/english/cnpq/index.htm. The funders had no role in study design, data collection and analysis, decision to publish, or preparation of the manuscript.

Competing Interests: The authors have declared that no competing interests exist.

*E-mail: rnrpereira@neuro.ufrn.br

\section{Introduction}

In the prefrontal cortex (PFC), the rescaling of synaptic weights mediated by long-term potentiation (LTP) and long-term depression (LTD) is thought to play an important role in working memory, decision-making, behavioral inhibition and attention shifting [1-3]. Much of the LTP/LTD dynamics in the PFC takes place at afferent terminals from subcortical structures, including the basolateral amygdala, ventral tegmental area, CAl of the hippocampus, and medial thalamic nuclei [4]. In particular, the mediodorsal thalamic nucleus (MD) is one of the most prominent sources of excitatory projections to the PFC, both in primates and rodents [5-10].

Several studies, ranging from functional imaging of the human brain to behavioral tests in animal models, have demonstrated the involvement of MD-PFC reciprocal projections in cognitive functions [11-16] and in pathological conditions, especially schizophrenia [17-20]. Electrophysiological studies in rodents have also shown that changes in PFC responses mediated by MD stimulation are involved in the modulation of hippocampusevoked activity in the PFC [21], fear extinction [22,23], and propagation of limbic seizures [24-27].
The MD-PFC circuit can be influenced by ascending cholinergic projections from the brainstem and basal forebrain [28-30], which represent important modulators of cognitive processes [3134] and oscillatory activity throughout the sleep-wake cycle [3537]. Unbalanced cholinergic neurotransmission is associated with cognitive decline, schizophrenia, Alzheimer's disease, and temporal lobe epilepsy [38-43]. In addition, several studies have shown that cholinergic activation regulates synaptic plasticity in adult thalamocortical loops comprising sensorial areas of the cortex [4448]. However, the cholinergic modulation of thalamus-induced plasticity in associative cortical areas is still poorly understood. In one of the few studies in vivo [49], it was shown that nicotinic agonists into the medial prefrontal cortex of rats (mPFC, prelimbic area) facilitated MD-evoked spikes and increased glutamate levels in the $\mathrm{mPFC}$. However, the authors did not evaluate long-term synaptic plasticity in the MD-mPFC pathway. Synaptic plasticity in this pathway was also shown to occur associated with fear learning in mice in the absence of any pharmacological treatment [22,23].

Recently, we have shown that muscarinic activation of the brain, by an M1 preferential agonist, enhances the hippocampalmPFC plasticity in two different ways. It specifically potentiates the 
late-phase LTP induced by high frequency stimulation [50], and promotes a long-lasting LTD in the mPFG induced by trains of low frequency stimulation [51]. Therefore, considering (1) that CAl and MD project and influence a common set of neurons in the mPFC [52,53], suggesting a possible substrate for the local interaction between hippocampal inputs and thalamocortical activity; and (2) that these projections can be modulated during general states of cholinergic activation achieved by the administration of muscarinic and nicotinic agonists, we decided to further investigate the muscarinic and nicotinic effects on LTP and LTD in the MD-mPFC circuit in vivo.

\section{Materials and Methods}

\subsection{Subjects}

A total of 71 adult male Wistar rats (250-450 g) were housed in standard rodent cages in a colony room maintained at $24^{\circ} \mathrm{C}$ under a $12 \mathrm{~h}$ light/ $12 \mathrm{~h}$ dark cycle with free access to food and water. All procedures were performed according to the Brazilian Council for Animal Experimentation (CONCEA) guidelines and approved by the Ethics Committee of the Ribeirão Preto School of Medicine (protocol number 125/2008). These guidelines abide by the National Institutes of Health rules for the care and use of laboratory animals (NIH Publications No. 8023, revised 1978). Experiments were designed to minimize the number of animals used and their suffering.

\subsection{Surgery and electrophysiology}

Rats were anesthetized with urethane $(1.2-1.5 \mathrm{mg} / \mathrm{kg}$, i.p., in $\mathrm{NaCl}$ 0.15 M; Sigma-Aldrich, USA) and placed in a stereotaxic frame (David Kopf Instruments, USA), and their body temperature was maintained at $37 \pm 0.5^{\circ} \mathrm{C}$ by using a heating pad (Insight Ltda, Brazil). When necessary, the level of anesthesia was maintained with supplementary injections of the anesthetic $(10 \%$ of the initial dose) after checking the tail pinch reflex. For electrode and cannula implantation, the skull was exposed and small holes were drilled to allow access to the left hemisphere prelimbic area $(\mathrm{PrL})$ of the mPFG (antero-posterior, AP: $+3.0 \mathrm{~mm}$; lateral to midline, L: $-0.4 \mathrm{~mm}$; ventral to dura mater, $\mathrm{V}:-3.2 \mathrm{~mm})$, left hemisphere MD (AP: $-1.9 \mathrm{~mm}, \mathrm{~L}:-0.4 \mathrm{~mm}, \mathrm{~V}:-4.8 \mathrm{~mm})$ and right hemisphere lateral ventricle $(\mathrm{LV} ; \mathrm{AP}:-0.5 \mathrm{~mm}, \mathrm{~L}$ : $+1.3 \mathrm{~mm}, \mathrm{~V}:-2.5 \mathrm{~mm}$ ) according to the rat brain atlas [54]. An additional hole was drilled over the parietal cortex in the right hemisphere to implant a micro-screw used as recording reference. Thereafter, a 23-gauge stainless-steel cannula was inserted into the brain and positioned $1 \mathrm{~mm}$ above the LV. The cannula was fixed to the skull with dental acrylic resin.

Teflon-insulated tungsten wires (60 $\mu \mathrm{m}$ diameter) were used to prepare stimulating and recording electrodes. A twisted bipolar electrode (vertical tip separation: $500 \mu \mathrm{m}$ ) was used for constant current stimulation of the $\mathrm{MD}$ and a monopolar electrode was used to record field post-synaptic potentials (fPSPs) in the mPFG. Both electrodes were lowered into the brain through the holes drilled on the skull, after removing the dura mater. Monophasic test pulses (200 $\mu$ s duration, 150-200 $\mu \mathrm{A}$; S88 Stimulator, Grass Technologies, USA) were delivered through the bipolar electrode every $20 \mathrm{~s}$, and the final position of the electrodes was adjusted to obtain the highest negative-going fPSP in the mPFG (amplitude $\geq 150 \mu \mathrm{V})$. fPSPs were amplified and filtered $(\times 100,0.01-1 \mathrm{KHz}$; P55-AC Pre-amplifier, Grass Technologies, USA) before digitization at $10 \mathrm{KHz}$ (PowerLab/16S; ADInstruments, Australia). For some animals, it was necessary to invert the polarity of the stimulation prior to the beginning of the experiments in order to increase the regularity of the fPSP. Although polarity influenced direction of stimulus artifact, it did not affect the latencies of fPSP negative peaks. Once the electrodes were positioned and the stimulation polarity was defined, electrical pulses were delivered every $20 \mathrm{~s}$ at increasing intensities $(60-500 \mu \mathrm{A})$ and the fPSP amplitudes were used to calculate input-output curves for each animal. Based on the input-output curves, we obtained the intensity necessary to produce maximum fPSP amplitudes and used $60-70 \%$ of such intensity to stimulate the MD during baseline, LTP or LTD induction and post-LTP or LTD recordings.

Baseline fPSPs were recorded for 30 min with single electrical pulses (200 $\mu \mathrm{s}$ duration; every $20 \mathrm{~s}$ ). Then, the drugs were microinjected through a 30 -gauge needle inserted into the cannula and connected to a $10 \mu \mathrm{L}$ microsyringe (Hamilton Company, USA) via a polyethylene tube. After microinjection, LTP or LTD was induced by delivery ofhigh-frequency (HFS) or low-frequency (LFS) trains of stimuli into the MD, respectively. Post-HFS/LFS recordings of fPSPs resumed for an additional $240 \mathrm{~min}$ to monitor the dynamics of $\mathrm{mPFC}$ responses. The HFS protocol consisted of two series (10 min apart) of 10 trains of 50 pulses $(250 \mathrm{~Hz})$. These trains were delivered every $10 \mathrm{~s}[23,50,55]$. LFS consisted of a single train of 1200 pulses $(2 \mathrm{~Hz})$ [23].

\subsection{Cholinergic drugs}

We used the following drugs: (1) pilocarpine hydrochloride (PILO, Sigma-Aldrich, USA), a non-selective muscarinic agonist with high affinity for M1-like receptors [56,57]; and (2) (-)-nicotine hydrogen tartrate (NIC, Sigma-Aldrich, USA), an agonist with high affinity for neural nicotinic receptors, especially $\alpha 7$ and $\alpha 4 \beta 2$ subtypes [58,59]. Artificial cerebrospinal fluid (aCSF; in mM: 2.7 $\mathrm{KCl}, 1.2 \mathrm{CaCl}_{2}, 1.0 \mathrm{MgCl}_{2}$, and $135.0 \mathrm{NaCl}$, with $\mathrm{pH} 7.3$ at room temperature) was used to dissolve both PILO $(40 \mathrm{nmol} / \mu \mathrm{L})$ and NIC $(320 \mathrm{nmol} / \mu \mathrm{L})$ salts. The concentrations of PILO and NIC were chosen based on a pilot experiment that measured the duration of the oscillatory changes induced in the $\mathrm{MPFC}$ and MD, and did not produce alteration of the physiological parameters of the animals, such as heart rate and salivation. aCSF without PILO or NIC was used as the control vehicle. The injections of PILO, NIC, or aCSF were delivered by intracerebroventricular route (i.c.v) in a volume of $1 \mu \mathrm{L}$ over a two-minute period.

\subsection{Experimental design}

To investigate the cholinergic modulation of MD-evoked synaptic plasticity in the $\mathrm{mPFC}$, three experiments were carried out. Experiment I tested the effects of cholinergic modulation on the induction and maintenance of LTP. For that, animals received PILO, NIC, or aCSF immediately before HFS and were divided into three groups: PILO-HFS, NIC-HFS, and aCSF-HFS, respectively. Experiment II tested the effects of cholinergic modulation on the induction and maintenance of LTD. Animals received PILO, NIC, or aCSF just before LFS and were also divided into three groups: PILO-LFS, NIC-LFS, and aCSF-LFS, respectively. Experiment III assessed the effects of PILO, NIC, or aCSF on basal mPFC responses induced by MD stimulation. Animals received PILO, NIC, or aCSF, but did not receive train stimulation and were grouped as PILO-Ctrl, NIC-Ctrl, and aCSFCtrl. Synaptic plasticity was analyzed by quantifying the average fPSP amplitude normalized to the baseline at different time points after synaptic plasticity induction. For that, fPSP amplitudes were averaged every $10 \mathrm{~min}$ and normalized as percentage of the baseline mean amplitude. 


\subsection{Local field potential analysis}

To monitor the state of brain activity associated to the muscarinic (PILO) and nicotinic (NIG) modulation, we recorded local field potentials (LFP) simultaneously in the $\mathrm{MD}$ and $\mathrm{mPFC}$ through the same electrodes used to induce and record LTP or LTD. Thalamic and neocortical LFPs were recorded during a 6 min period divided into 2 min blocks: before, during and after i.c.v microinjection. After down sampling to $200 \mathrm{~Hz}$ and low-pass filtering $(0.5-100 \mathrm{~Hz})$, Welch's power spectral densities (Hanning window) were calculated every $10 \mathrm{~s}$ epochs. Spectral densities were estimated for each epoch after averaging periodograms calculated from eight sections with $50 \%$ overlap. Delta $(0.5-4 \mathrm{~Hz})$, theta $(4$ $12 \mathrm{~Hz}$ ), beta $(12-30 \mathrm{~Hz})$ and gamma $(30-80 \mathrm{~Hz}$, removing $58-$ $62 \mathrm{~Hz}$ noise) normalized powers were calculated using custommade MATLAB scripts (The MathWorks, Natick, MA). Normalized band powers were compared to evaluate the effects of PILO and NIC on the oscillatory activity recorded in the MD and mPFG.

\subsection{Histology}

After each recording session, a current pulse (1 mA, $1 \mathrm{~s})$ was delivered through the stimulation and recording electrodes to produce a small electrolytic lesion for electrode localization. The animals received an additional injection of the anesthetic and had their brains removed after decapitation. The brains were postfixed in $10 \%$ formaldehyde-saline solution for $14 \mathrm{~h}$ at $4{ }^{\circ} \mathrm{C}$ and cryoprotected for $48 \mathrm{~h}$ in $20 \%$ sucrose solution (in $0.1 \mathrm{M}$ sodium phosphate buffer, $\mathrm{pH}$ 7.4). After rapid freezing in dry ice-chilled isopentane, $30 \mu \mathrm{m}$-thick slices were cut in a cryostat, mounted on gelatinized slides and stained with cresyl violet. Electrode tip positions and cannula tracts were determined after analysis of brain sections under the optic microscope (AxioPhot, Carl Zeiss Inc.).

\subsection{Statistical analysis}

Analysis of group differences following HFS or LFS was carried out by two-way ANOVA with repeated measures (group: fixed factor vs. time: repeated measures). The same ANOVA was used to test power spectrum differences in the $\mathrm{mPFC}$ and $\mathrm{MD}$ along the 6 min recording of LFPs. The Newman-Keuls post hoc test was applied following ANOVAs when necessary. All results are expressed as the mean \pm SEM and significance level was set to 0.05 .

\section{Results}

\subsection{Accuracy of implants}

All animals included in our analysis had the stimulation electrode tips positioned within the MD, most often in its anterior and medial aspects, which contain the highest density of mPFGprojecting cells according to retrograde tracing [60]. Recording electrode tips were most frequently observed in the medial wall of the ipsilateral mPFC, at the level of PrL. Cannulae placement was observed approximately $1 \mathrm{~mm}$ above the $\mathrm{LV}$, so that only the microinjection needle reached the LV (Figure 1).

\subsection{Characteristics of mPFC responses evoked by MD stimulation}

In all experiments, we first positioned the recording electrode at the PrL area of the mPFC based on stereotaxic coordinates [54] and then, lowered the stimulation electrode in $200 \mu \mathrm{m}$ steps while applying pulses each $20 \mathrm{~s}$ (electrical parameters described in the methods section). No fPSP was found until the stimulation electrode reached $3.0 \mathrm{~mm}$ below the dura mater (presumably at the corpus callosum level), from where we consistently elicited fPSPs with a negative peak at latency of $\sim 9 \mathrm{~ms}$ (Figure 1). As the stimulation electrode crossed the hippocampus on its way towards the MD, the same profile of fPSP was repeatedly elicited until approximately $4.2-4.4 \mathrm{~mm}$ below the dura mater, when we observed a shift of the negative peak from a latency of $\sim 9$ to $\sim 13 \mathrm{~ms}$. From that point on, we continued to lower the electrode until 4.8-5.2 mm below dura mater (at the MD level), when we obtained the strongest and most reliable negative-going fPSP and concluded the implantation. The prefrontal fPSPs obtained by stimulation throughout the hippocampus may occur due to the activation of passing fibers, since retrograde tracing data from the literature do not show hippocampal cells projecting to the $\mathrm{mPFC}$ at the anteroposterior level where our stimulation electrodes were implanted [59]. Nevertheless, fPSPs elicited during the trajectory of the stimulating electrode were useful as references for the refinement of the dorso-ventral implant position.

In approximately half of the subjects, the MD-evoked fPSPs showed two distinct negative peaks, which we termed N1 and N2 (Figure 1). When clearly detected, N1 was a low-amplitude $(108.20 \pm 9.32 \mu \mathrm{V})$ short-latency $(6.85 \pm 0.15 \mathrm{~ms})$ negative peak, but in some cases it was too subtle to be defined. Differently, N2 was a negative peak characterized by high amplitude $(270.00 \pm 17.10 \mu \mathrm{V})$ and long latency $(13.43 \pm 0.17 \mathrm{~ms})$, and was consistently detected in all subjects. PPSPs recorded in the present study had latency and amplitude profiles resembling those previously described in awake mice $[22,23]$. As reported by these authors, it was difficult to dissociate the short-latency component of the fPSP depending on the case. Thus, we adopted a similar definition and used measurements of the consistent N2 peak amplitude as an index of field synaptic response in the mPFG. Table 1 shows baseline N2 parameters for all groups in the present study. As expected, no significant differences were detected between groups when latency and amplitude were analyzed (one-way ANOVA; $p>0.05$ ).

Pirot et al. [5,61] showed that MD stimulation evoked two categories of unitary responses in the $\mathrm{mPFC}$, which were distinguished by their latencies: short $(3.46 \pm 0.05 \mathrm{~ms})$ and long $(13.67 \pm 0.22 \mathrm{~ms})$. Short-latency responses correspond to the actual recruitment of MD-mPFC thalamocortical fibers, whereas longlatency responses correspond to the activation of intracortical axon collaterals, originating from mPFC-MD corticothalamic fibers. Indeed, electrical pulses applied within the MD inevitably stimulate mPFC-derived axon terminals, eliciting antidromic action potentials towards the $\mathrm{mPFC}$, and thereby recruiting the axon collaterals of corticothalamic fibers [6]. Differently from Pirot et al. [5,61], Herry et al. [22] were the first to examine MDevoked fPSPs in the mPFC to study long-term synaptic plasticity in the thalamocortical circuit, interpreting the short-latency component of their fPSPs as a response to MD-mPFG activation. However, given that the they were not always able to identify the short-latency component depending on the subject, the authors (as well as Herry and Garcia [23]) measured the amplitude of the long-latency component (N2) of the fPSPs. Similarly, we decided to use $\mathrm{N} 2$ as an index of mPFC plasticity. Despite the low selectivity of MD electrical stimulation, we consider that MDevoked plasticity may control the excitatory reverberation in the MD-mPFC circuit as a whole. In addition, Herry et al. [22] and Herry and Garcia [23] showed that LTD of MD-evoked fPSPs correlate to learning behaviors (i.e., resistance to extinction of conditioned fear), reinforcing the functional implications of MDmPFC long-term plasticity. 
A

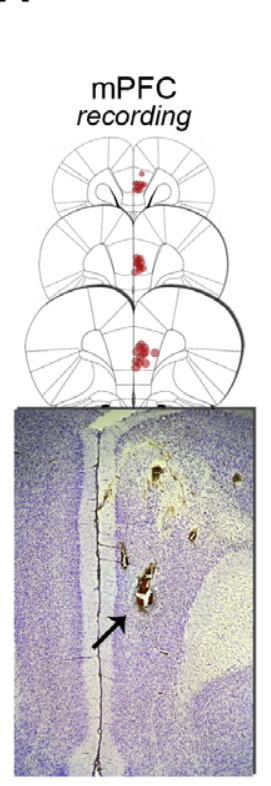

B
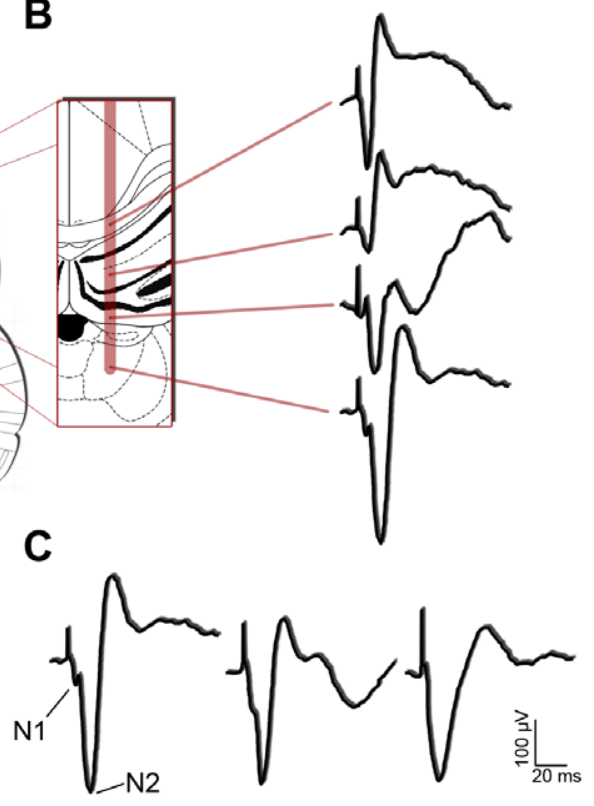

Figure 1. Histological validation of implants and typical prefrontal fPSPs. (A) Positioning of electrodes and cannulae from a coronal point of view. For mPFC and MD, coronal plates represent the anteroposterior variation of the electrode tip positioning (red dots), preferentially at the PrL of mPFC (layer-inespecific) and the anterior half of MD (subdivision-inespecific), both in the left hemisphere. For LV, the coronal plates show the variation of the cannula positioning (red bars) just above the right lateral ventricle, where the experimental drugs were injected. In the representative Nissl-stained coronal sections, the arrows point to typical electrolytic lesions (applied after the end of the experiments) and cannula tract. (B) Once the recording electrode was positioned at the MPFC, a typical dorsoventral profile of fPSPs was consistently evoked across subjects, while the stimulation electrode was lowered towards the MD (see details in the text). (C) Diversity of MD-evoked fPSPs recorded in the mPFC. The first fPSP shows a clear differentiation between two distinct negative peaks, which we termed N1 (amplitude 108.20 $\pm 9.32 \mu \mathrm{V}$; latency $6.85 \pm 0.15 \mathrm{~ms}$ ) and N2 (amplitude $270.00 \pm 17.10 \mu \mathrm{V}$; latency $13.43 \pm 0.17 \mathrm{~ms}$ ). Such an aspect of fPSP was obtained in approximately half the subjects. In some cases, like the second fPSP, the N1 peak was subtle. Finally, in some other cases, like the third fPSP, the N1 peak was indistinguishable.

doi:10.1371/journal.pone.0047484.g001

\subsection{Concentration-dependent effects of PILO and NIC on MD and mPFC oscillations}

We have recently determined the latency and duration of the muscarinic effect of PILO on LFP oscillations in the hippocampus and $\mathrm{mPFC}$ following i.c.v. injections of different concentrations of the drug. PILO $40 \mathrm{nmol} / \mu \mathrm{L}$ (injected volume of $1 \mu \mathrm{L}$ ) shifts the pattern of urethane-driven slow waves to a transient state of increased high-frequency oscillations for $\sim 15 \mathrm{~min}$ with a latency $\sim 1 \mathrm{~min}$. In the present study, we show that LFPs recorded in the

Table 1. Amplitude and latency of MD-evoked fPSPs recorded in the $\mathrm{mPFC}$ during baseline.

\begin{tabular}{lll}
\hline Groups & Amplitude $(\mu \mathbf{V})$ & Latency $(\mathbf{m s})$ \\
\hline PILO-HFS & $231.25 \pm 31.19$ & $13.22 \pm 0.31$ \\
NIC-HFS & $250.00 \pm 56.78$ & $14.57 \pm 0.39$ \\
aCSF-HFS & $335.00 \pm 83.00$ & $13.41 \pm 0.42$ \\
PILO-LFS & $277.50 \pm 31.83$ & $13.22 \pm 0.51$ \\
NIC-LFS & $262.50 \pm 64.96$ & $13.65 \pm 0.68$ \\
aCSF-LFS & $341.25 \pm 63.82$ & $13.16 \pm 0.36$ \\
PILO-Ctrl & $255.00 \pm 31.40$ & $11.99 \pm 0.44$ \\
NIC-Ctrl & $285.00 \pm 50.92$ & $14.01 \pm 0.60$ \\
aCSF-Ctrl & $190.00 \pm 14.52$ & $13.72 \pm 0.57$ \\
\hline
\end{tabular}

Intergroup one-way ANOVA showed no significant differences. Data are shown as the mean \pm SEM.

doi:10.1371/journal.pone.0047484.t001
MD and mPFG are also shifted towards faster oscillations in a concentration-dependent manner in response to NIC (Figure 2). In particular, the effect of $\mathrm{NIC} 320 \mathrm{nmol} / \mu \mathrm{L}$ (1 $\mu \mathrm{L}$, i.c.v.) on thalamic and cortical LFPs lasted for $\sim 12$ min, matching the duration of HFS and LFS protocols used in this study. Therefore, PILO and NIC were used at these concentrations (respectively, $40 \mathrm{nmol} / \mu \mathrm{L}$ and $320 \mathrm{nmol} / \mu \mathrm{L}$ ) in all experiments.

\subsection{Cholinergic modulation of the oscillatory activity in the hippocampus and mPFC}

We quantified the spectral content of cortical and thalamic LFPs before, during, and after PILO and NIC microinjections. Figure 3 shows the integrated relative power spectra changes in MD and mPFG LFPs along the 6 min period of LFP continuous recording. We can see that PILO and NIC significantly decreased delta and proportionally potentiated theta, beta, and gamma oscillations. Particularly, the NIC effects on the four frequency bands had shorter latencies than the PILO effects, since the latter were already evident during the microinjection window. In addition, NIC induced a stronger potentiating effect on beta and gamma. Microinjection of aCSF by itself did not alter the urethane-induced slow-wave context. The ANOVA $F$ values for interaction effects are as follows. mPFC delta: $F_{(58,1653)}=5.181$; mPFC theta $F_{(58,1653)}=4.039$; $\mathrm{mPFC}$ beta: $F_{(58,1653)}=8.930$; mPFG gamma: $F_{(58,1653)}=13.880 ;$ MD delta: $F_{(58,1653)}=6.040$; MD theta: $F_{(58,1653)}=5.538 ; \mathrm{MD}$ beta: $F_{(58,1653)}=13.643 ; \mathrm{MD}$ gamma: $F_{(58,1653)}=16.578$. The $p$ values for all the ANOVAs were less than 0.001 . 


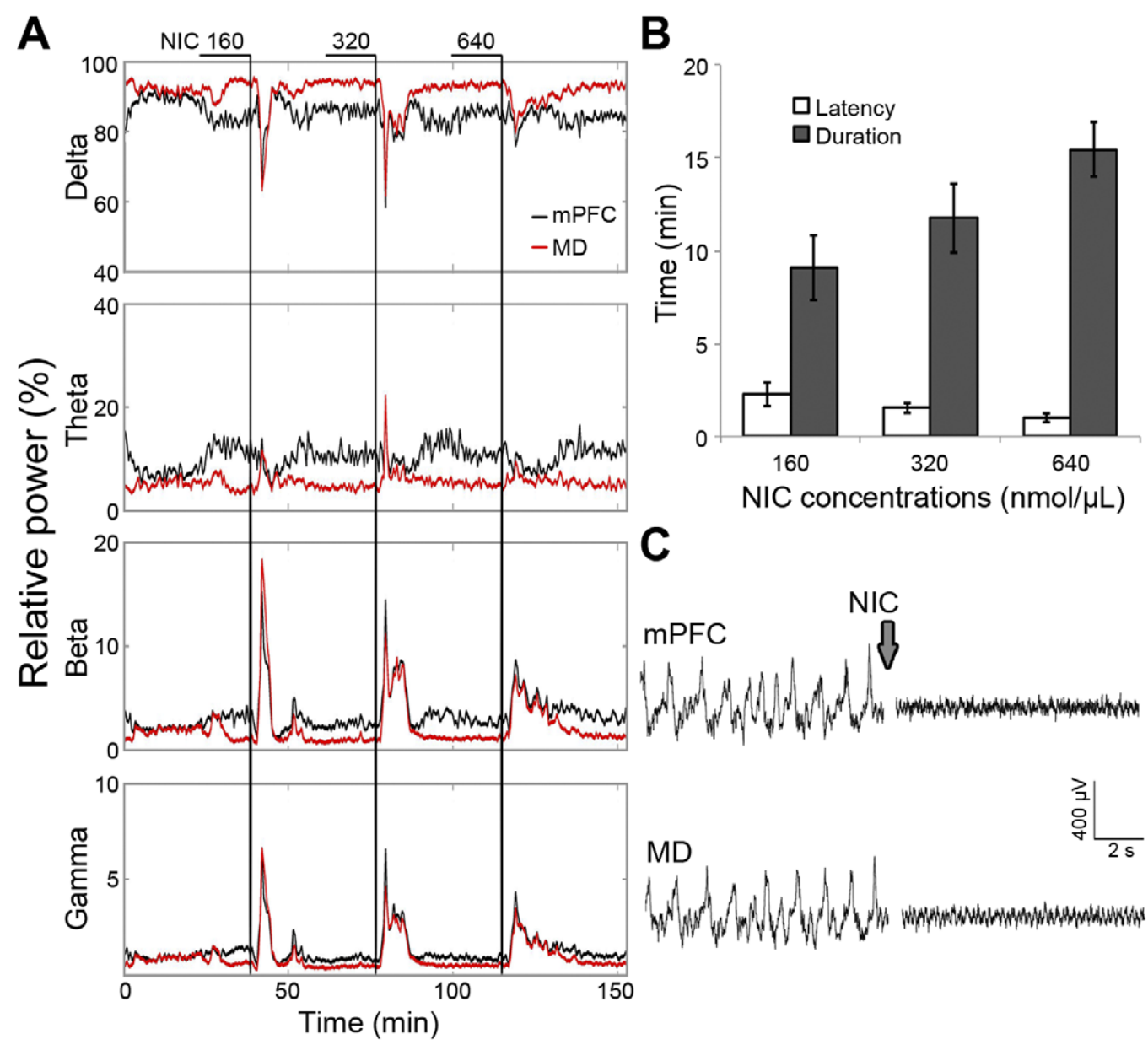

Figure 2. Concentration-dependent effect of NIC on forebrain oscillatory activity. Different concentrations of NIC (160, 320, and $640 \mathrm{nmol} /$ $\mu \mathrm{L} ; 1 \mu \mathrm{L}$ icv) were injected while LFPs were continuously recorded during $120 \mathrm{~min}$ for analysis of the power spectrum at delta $(0.5-4 \mathrm{~Hz})$, theta $(4-$ $12 \mathrm{~Hz})$, beta $(12-30 \mathrm{~Hz})$, and gamma $(30-80 \mathrm{~Hz})$ frequency bands. (A) Continuous thalamic and cortical LFP recording from a representative subject. (B) Analysis of latency and duration of LFP changes induced by the injection of the different NIC concentrations in a sample of eight rats. The sequence of injections at the different concentrations was randomized (data shown as the mean $\pm \mathrm{SEM}$ ). (C) Representative EEG tracings from mPFC and MD before and after NIC injection. Based on these experiments, we decided to use NIC $320 \mathrm{nmol} / \mu \mathrm{L}$ to induce a transient effect matching the duration of HFS and LFS protocols.

doi:10.1371/journal.pone.0047484.g002

\subsection{Cholinergic activation triggers a delayed form of LTP} in the $\mathrm{MPFC}$

Application of HFS in the MD did not induce LTP in the mPFC by itself. The amplitude of mPFC fPSPs recorded following aCSF injection (aCSF-HFS group) did not change for $4 \mathrm{~h}$ (Figure 4). In contrast, we observed that both PILO and NIC induced a delayed-onset form of LTP, with similar kinetics (PILOHFS and NIC-HFS groups; interaction effect: $F_{(46,460)}=1.714$; $p=0.003)$. As depicted in figure 4 , LTP induced by PILO and by NIC began to emerge approximately $2 \mathrm{~h}$ after HFS, with values reaching approximately $120-130 \%$ of baseline level.

\subsection{Cholinergic activation suppresses a long-lasting form of LTD in the MPFC}

In the groups in which LFS was applied after aCSF microinjection, we observed stable LTD with duration of $4 \mathrm{~h}$, at 80-90\% of baseline level (Figure 5). In contrast, PILO-LFS and NIC-LFS subjects showed a complete suppression of LTD throughout the $4 \mathrm{~h}$ monitoring period. The effects had similar kinetics for both groups and apparently converted the LTD into a subtle, but stable LTP (Figure 6; group effect: $F_{(2,21)}=6.719$; $p=0.006)$.

\subsection{Basal mPFC fPSPs are not affected by NIC or PILO in the long term}

While PILO and NIC modulated HFS and LFS effects on MDevoked prefrontal responses, these agonists alone did not affect $\mathrm{mPFC}$ responses in the long term. Although we observed a brief potentiation induced by NIC in the first $20 \mathrm{~min}$ (interaction effect: $\left.F_{(46,480)}=2.148 ; p<0.001\right)$, mPFC responses quickly recovered and did not show the sustained effect observed after HFS and LFS (Figure 6). These results support the fact that the cholinergic modulation observed after HFS and LFS is due to the interaction between the stimulation protocols and the cholinomimetic states promoted by PILO and NIC.

By separately comparing aCSF-LFS with aCSF-Ctrl or aCSFHFS curves, we showed that LTD was significantly induced after LFS, but our HFS protocol was not sufficient to induce LTP (aCSF-LFS vs. aCSF-Ctrl: group effect, $F_{(1,14)}=7.638, p=0.015$, and time effect, $F_{(23,315)}=1.587, p=0.045$; aCSF-LFS vs. aCSFHFS: group effect, $F_{(1,14)}=19.074, p<0.001$, and interaction 


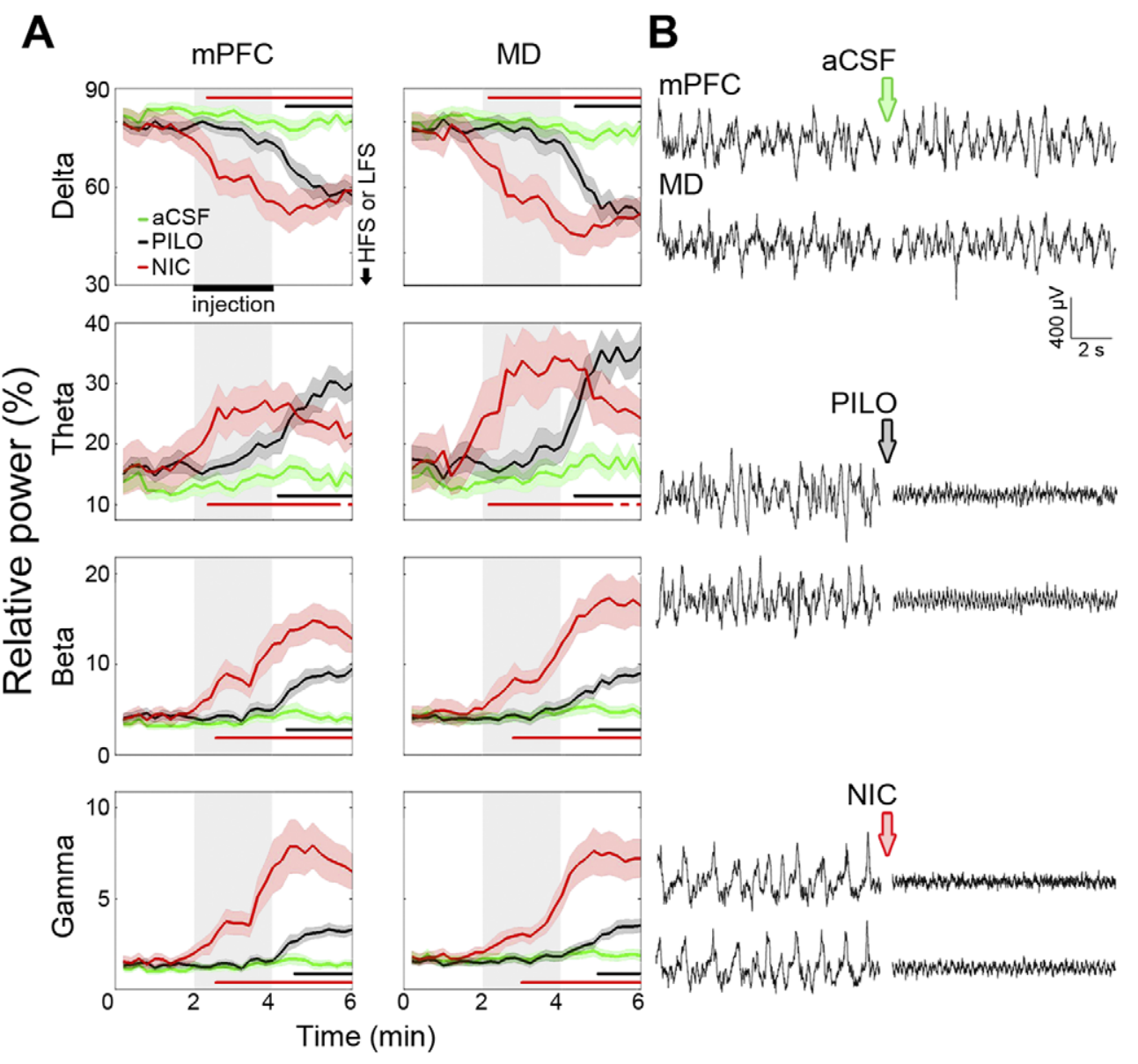

Figure 3. LFP power spectrum comparing MPFC and MD oscillatory activity before, during, and after microinjection. (A) Charts detailing PILO and NIC effects on LFPs, showing a decrease in delta $(0.5-4 \mathrm{~Hz})$, as well as an increase in theta $(4-12 \mathrm{~Hz})$, beta $(12-30 \mathrm{~Hz})$, and gamma $(30-80 \mathrm{~Hz})$ relative power. The LFP changes induced by NIC occurred earlier than those induced by PILO, with a shorter duration of theta potentiation, and a stronger potentiation of beta and gamma waves. The data were obtained from all aCSF, PILO and NIC rats of the synaptic plasticity experiments. Significant differences are indicated by two-way repeated measures ANOVA followed by the Newman-Keuls post-hoc test (black bar: aCSF vs. PILO; red bar: aCSF vs. NIC). (B) Representative EEG tracings from mPFC and MD before and after icv microinjections. Data are shown as the mean \pm SEM.

doi:10.1371/journal.pone.0047484.g003

effect, $F_{(23,315)}=1.734, p<0.021 ;$ two-way repeated measures ANOVA; Figure S1). Given the subtle and stable LTP $(\sim 110 \%)$ observed in PILO-LFS and NIC-LFS groups, four additional comparisons were made: PILO-LFS vs. PILO-Ctrl, PILO-LFS vs. PILO-HFS, NIC-LFS vs. NIC-Ctrl, and NIC-LFS vs. NIC-HFS. All comparisons showed no intergroup differences. Thus, PILO and NIC were able to induce LTP (up to $\sim 130 \%$, Figure 4 ) when applied before an ineffective HFS protocol, whereas they promoted a stable but of lower magnitude LTP following the LTD-inducing LFS protocol.

\subsection{Thalamic and cortical oscillatory activity correlates with the peak of prefrontal LTP}

To test whether the magnitude of prefrontal fPSPs correlated to the level of oscillatory changes induced by PILO and NIC in the $\mathrm{MD}$ and $\mathrm{mPFC}$, we pooled data from all rats used in the synaptic plasticity experiments and divided them into three major groups (HFS, LFS, and Ctrl), regardless the injection they received. We then calculated the Pearson's linear correlation between the relative power at four frequency bands (delta, theta, beta, and gamma) and the mean fPSP amplitude every 10 min blocks following HFS, LFS, or Ctrl.
In HFS rats, the most evident results show a negative correlation between the amplitude of cortical fPSPs and the relative power of delta recorded in the $\mathrm{MPFC}$ and MD throughout the experiments. In addition, we observed a positive correlation of the amplitude of cortical fPSPs with the relative power of theta and beta recorded specifically in the $\mathrm{mPFC}$, Therefore, the lower the relative delta power after microinjection, the higher the prefrontal responses to MD stimulation during the $4 \mathrm{~h}$ monitoring. Similarly, the higher the relative theta and beta powers after microinjection, the higher the prefrontal responses. The significant correlations were particularly concentrated $120 \mathrm{~min}$ after HFS, nearly matching the peak of prefrontal LTP in our HFS experiments (Figure 7).

Significant correlations were also found in LFS rats although they were less frequent and occurred only during the first $150 \mathrm{~min}$ of monitoring. Significant results were restricted to delta (negative correlations) and theta oscillations (positive correlations) recorded both in the $\mathrm{mPFC}$ and MD (e.g., at 20 min after LFS, MD delta: $\mathrm{r}=-0.497, p=0.026$; MD theta: $\mathrm{r}=0.489, p=0.028$; at $30 \mathrm{~min}$ after LFS, mPFG delta: $\mathrm{r}=-0.521, p=0.038$; $\mathrm{mPFG}$ theta: $\mathrm{r}=0.537, p=0.032)$. Therefore, delta and theta powers after microinjection were negatively and positively correlated with the 

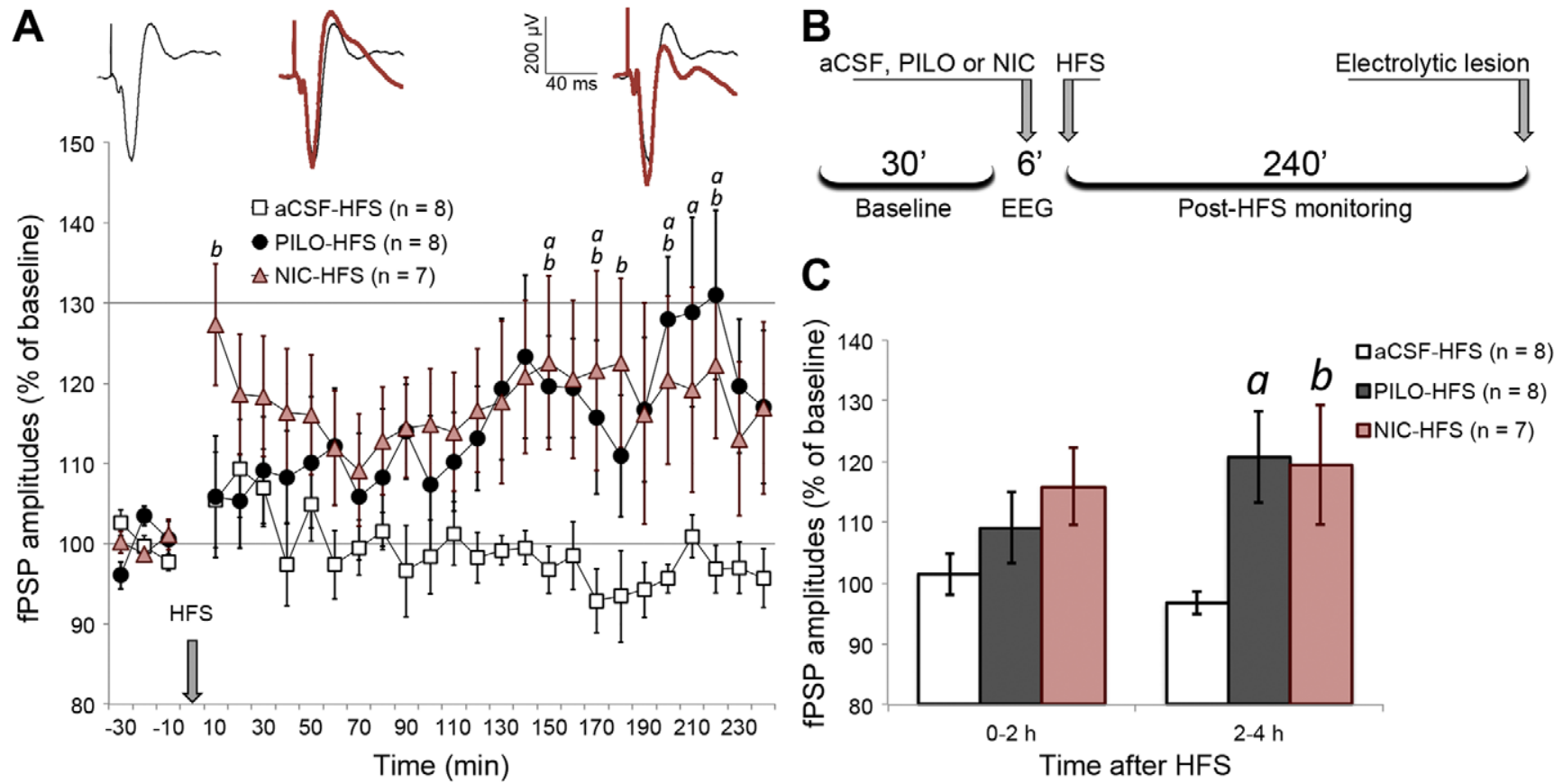

Figure 4. HFS induced a late LTP in MPFC only when applied under PILO and NIC effects. (A) fPSP amplitude throughout baseline (30 min) and post-HFS monitoring (240 min), depicting amplitudes averaged in 10-min blocks and normalized in relation to baseline mean amplitude. Significant differences are indicated by two-way ANOVA with repeated measures, followed by the Newman-Keuls post-hoc test ( $a=$ PILO vs. aCSF; $b=$ NIC vs. aCSF; $p<0.05$ ). The sequence of averaged fPSPs above the chart represents a typical PILO-HFS experiment, where post-HFS fPSPs (red) are superimposed on baseline fPSPs (black). Such fPSPs are roughly aligned with the time course of the chart. (B) Timeline summarizing the procedures for HFS experiments. (C) Data from chart A clustered in blocks of $2 \mathrm{~h}$ after HFS, highlighting PILO and NIC significant effects restricted to the second half of the monitoring. Data are shown as the mean \pm SEM. doi:10.1371/journal.pone.0047484.g004

A

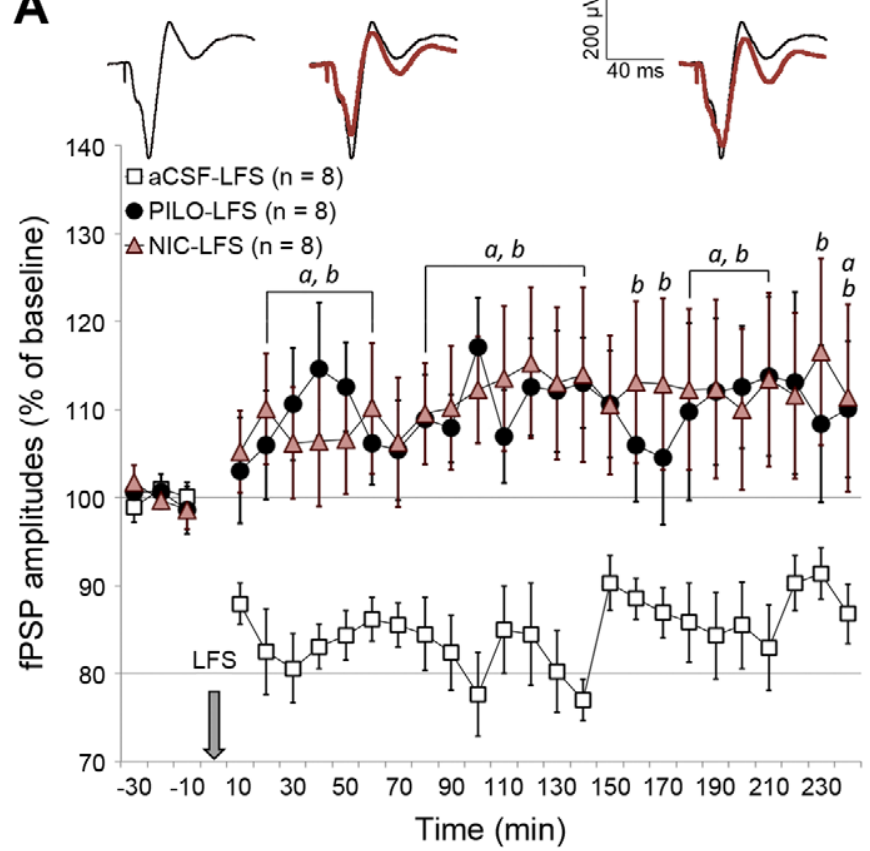

B
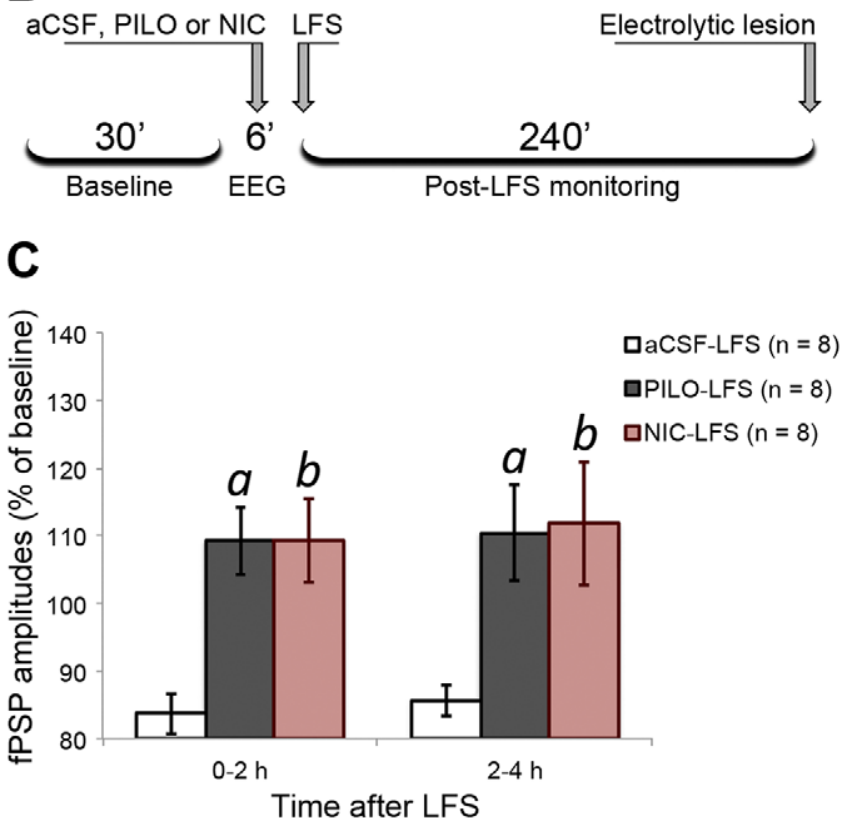

Figure 5. LFS induced a stable LTD in MPFC only when applied under urethane-driven slow-wave context. (A) fPSP amplitude throughout baseline $(30 \mathrm{~min})$ and post-LFS monitoring $(240 \mathrm{~min})$, depicting amplitudes averaged in 10 min blocks and normalized in relation to baseline mean amplitude. Significant differences are indicated by two-way ANOVA with repeated measures, followed by the Newman-Keuls post-hoc test $(a=$ PILO vs. aCSF; $b=$ NIC vs. aCSF; $p<0.05)$. The sequence of averaged fPSPs above the chart represents a typical aCSF-LFS experiment, where post-LFS fPSPs (red) are superimposed on baseline fPSPs (black). Such fPSPs are roughly aligned with the time course of the chart. (B) Timeline summarizing the procedures for LFS experiments. (C) Data from chart A clustered in blocks of $2 \mathrm{~h}$ after LFS, showing the stability of PILO and NIC effects throughout the monitoring. Data are shown as mean \pm SEM.

doi:10.1371/journal.pone.0047484.g005 
A

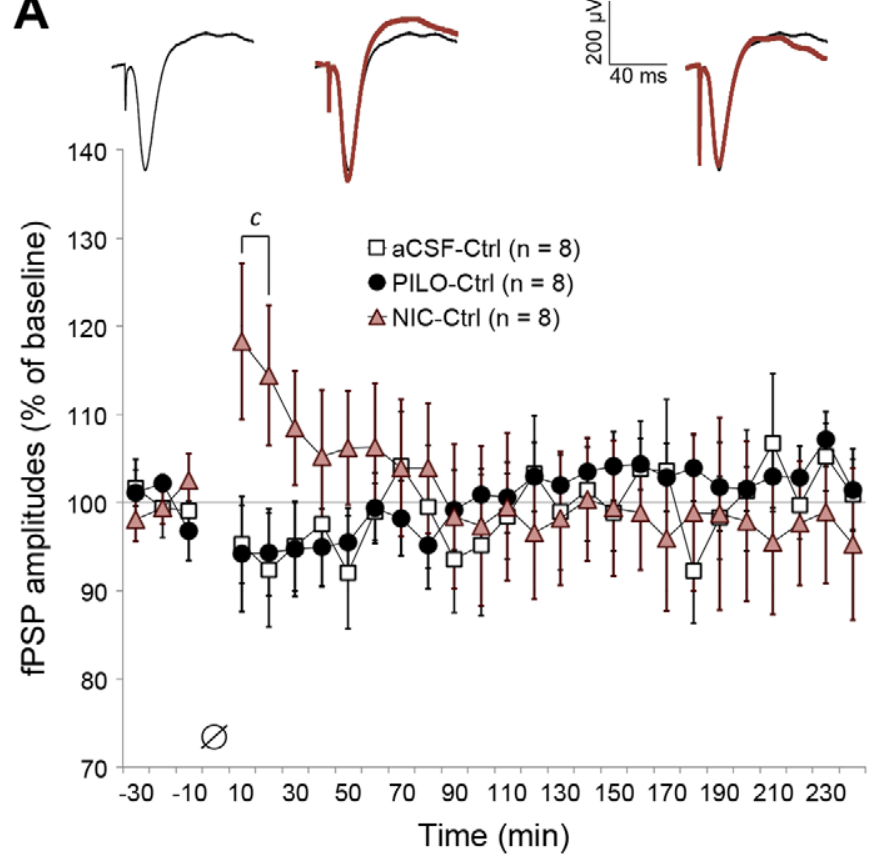

B
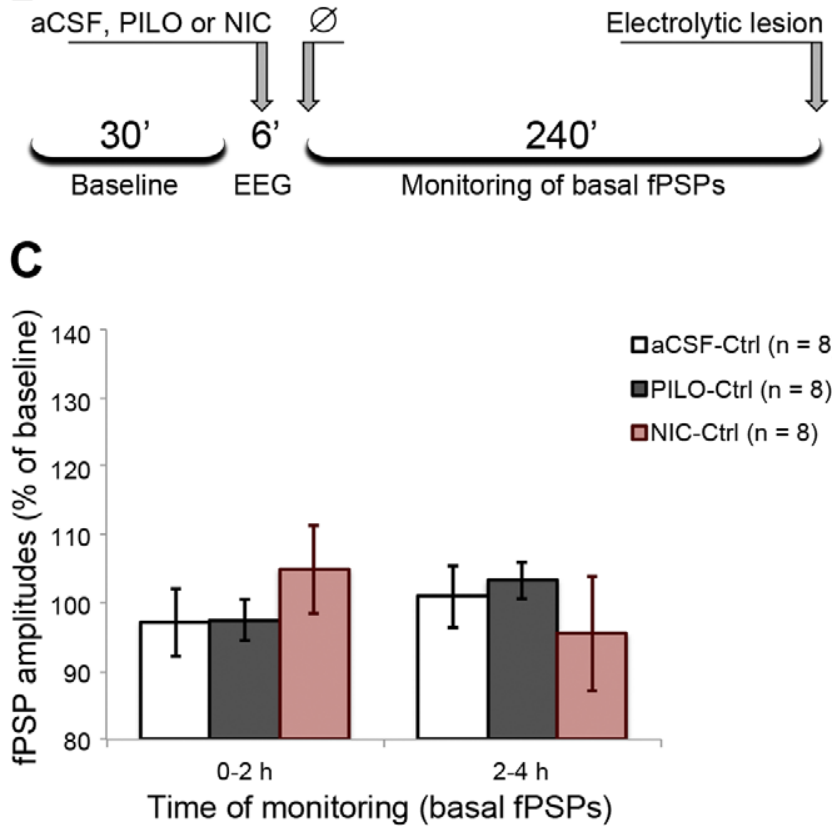

Figure 6. PILO and NIC microinjection alone did not induce long-term changes in MD-evoked prefrontal fPSPs. (A) fPSP amplitude throughout baseline $(30 \mathrm{~min}$ ) and monitoring $(240 \mathrm{~min})$, depicting amplitudes averaged in $10 \mathrm{~min}$ blocks and normalized in relation to baseline mean amplitude. Significant differences are indicated by two-way ANOVA with repeated measures, followed by the Newman-Keuls post-hoc test $(c=$ NIC vs. both aCSF and PILO; $p<0.05$ ). The sequence of averaged fPSPs above the chart represents a typical NIC-Ctrl experiment, where fPSPs recorded during the $4 \mathrm{~h}$ monitoring (red) are superimposed on baseline fPSPs (black). Such fPSPs are roughly aligned with the time course of the chart. (B) Timeline summarizing the procedures for Ctrl experiments, in which the empty-set symbol represents absence of train stimulation. (C) Data from chart A clustered in blocks of $2 \mathrm{~h}$ of monitoring. Data are shown as the mean \pm SEM.

doi:10.1371/journal.pone.0047484.g006

prefrontal responses to MD stimulation during the first half of the monitoring respectively, which is consistent with the LTDsuppressing effects of PILO and NIC in our experiments.

\section{Discussion}

The present study describes the effects of the muscarinic and nicotinic brain activation on the long-term synaptic plasticity in the mPFC induced by electrical stimulation of the MD in vivo. We can divide our results into five main findings: (1) the muscarinic and nicotinic activation, induced by PILO and NIC, promoted a delayed-onset LTP in the $\mathrm{mPFC}$ when applied prior to HFS; (2) in contrast, both PILO and NIC suppressed LTD in the mPFC triggered by LFS; (3) PILO and NIC did not affect basal synaptic transmission in the long term, but NIC showed a transient potentiating effect both in the control and HFS condition with a mean duration of $20 \mathrm{~min}$; (4) the network effects of PILO and NIC were detected by a transient decrease in the prevalence of delta waves $(0.5-4 \mathrm{~Hz})$ and a proportional increase of fast oscillations $(4-80 \mathrm{~Hz})$ in the cortex and thalamus; and (5) although PILO and NIC induced brief oscillatory changes in the MD and mPFC, such changes showed significant correlation to the increase in fPSP amplitudes recorded more than two hours after HFS or LFS.

In two recent reports, we used a similar design in anesthetized rats to assess the muscarinic modulation of LTP and LTD in the hippocampus-mPFG pathway [50,51]. We showed that muscarinic activation, produced by systemic administration of PILO prior to HFS in CAl, prevented the decay of LTP $2 \mathrm{~h}$ after its induction [50]. In contrast, the intracerebroventricular administration of PILO converted a subthreshold transient synaptic depression into a robust and stable LTD, lasting up to $4 \mathrm{~h}$ [51].
These results indicate that the brain muscarinic activation enhances both forms of synaptic plasticity in the mPFC suggesting an important cholinergic role in the bidirectional control of hippocampo-prefrontal plasticity. Our present findings, on the other hand, support a distinct function for the cholinergic modulation of MD-evoked $\mathrm{mPFC}$ plasticity, in which both muscarinic and nicotinic agonists either enhance LTP or suppress LTD. In fact, PILO and NIC converted a subthreshold HFS into a late-onset LTP and completely blocked LTD induced by LFS, with a net potentiating effect after HFS and a net suppressive effect after LFS. Besides, in the absence of stimulation, the application of NIC induced a transient enhancement of MD-mPFC responses that decayed to basal levels in $20 \mathrm{~min}$. However, it is still unknown if NIC produces similar effects on the CAl-mPFC responses in vivo.

Neurochemically, the reciprocal communication between MD and $\mathrm{mPFC}$ is mediated by AMPA and NMDA receptors, and regulated by several neuromodulators [5,49,61-65]. It is well described that NMDA-dependent LTP and LTD relies on the intracellular signaling mediated by cytosolic $\mathrm{Ca}^{2+}$, which controls AMPA receptor trafficking to and from the postsynaptic density [67]. These mechanisms can be triggered by HFS or LFS, and enhanced by simultaneous activation of Ml-like muscarinic receptors that are widely distributed in the frontal cortex, resulting in sustained or reduced membrane depolarization [31,68-71]. Moreover, some reports have shown that presynaptic nicotinic receptors, mainly the low-affinity $\alpha 7$ and high-affinity $\alpha 4 \beta 2$ subtypes, can exert a calcium-dependent potentiation of the thalamocortical transmission [34,47,59,72,73], which could explain the net potentiating effects of PILO and NIC. Consistently, Gioanni et al. [49] have shown that nicotinic agonists facilitate MD-evoked firing and promote glutamate release in the mPFC. 


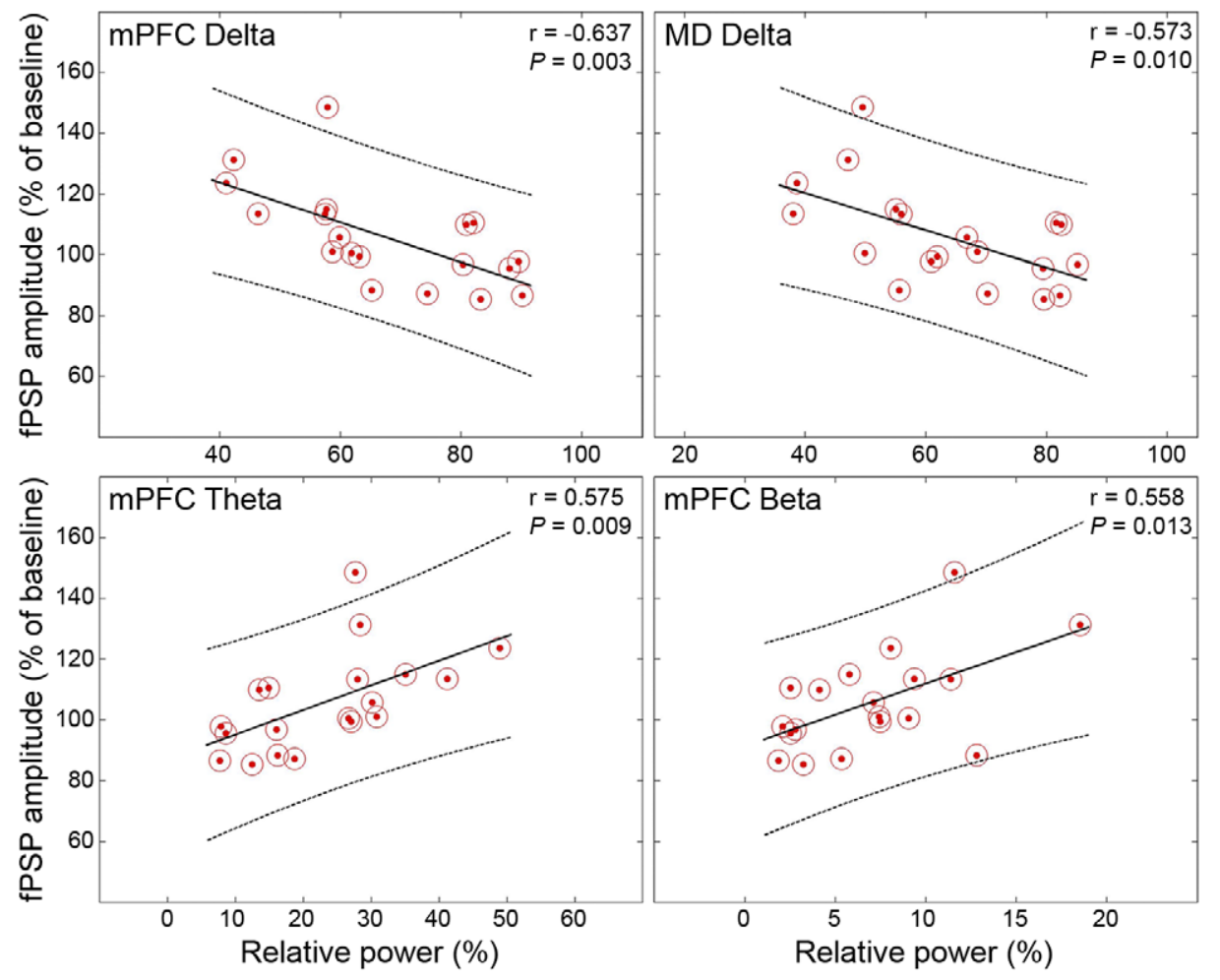

Figure 7. There were correlations between the level of LFP changes and fPSP amplitudes throughout the monitoring. The four plots represent the highest concentration of significant correlations, specifically between the delta, theta, and beta bands recorded prior to HFS and the 120-150 min time point after HFS. The lower the delta in MPFC and MD, the higher the fPSP amplitudes (top). The higher the theta-beta in mPFC, the higher the fPSP amplitudes (bottom). doi:10.1371/journal.pone.0047484.g007

The authors also observed that unilateral MD lesions reduced in $\sim 40 \%$ the binding of $3 \mathrm{H}$-nicotine in the $\mathrm{mPFC}$, indicating that thalamic presynaptic terminals in the $\mathrm{mPFC}$ are rich in nicotinic receptors. However, our data do not allow us to make a clear dissection of the individual effects of PILO and NIC on specific receptor subtypes, as we did not use cholinergic antagonists to block their actions.

Although previous studies have shown that excitability and neurotransmission in thalamocortical loops are susceptible to cholinergic modulation $[46,48,66]$, there is still a lack of understanding on how synaptic plasticity in the MD-mPFC is affected by cholinergic-driven brain states. Here, our strategy of injecting PILO or NIC into the ventricle of anesthetized rats allowed us to achieve a global cholinergic activation that tried to mimic a physiological state of arousal or rapid-eye-movement (REM) sleep, which are endogenously regulated by ascending projections from the brainstem, basal forebrain, and septum $[29,30]$. Despite the limitation of recording during anesthesia, it was recently shown that urethane anesthesia mimics the state alternations of sleep, suggesting its possible use as a model to study sleep oscillations [95]. Interestingly, the cholinergic control of oscillatory states of sleep is relatively preserved by urethane [9095]. Indeed, the transient effects of PILO and NIC on LFPs under urethane resembled the oscillatory pattern observed in REM sleep episodes [84], which are primarily induced by cholinergic projections depolarizing thalamocortical cells and inducing their tonic firing [36,85,88-89].

A plausible implication of our findings is that acetylcholine through muscarinic and nicotinic receptors might favor MD inputs to the mPFC during cholinergic-driven states such as in sleep or during cognitive demands during waking, leading to a long lasting strengthening of thalamo-prefrontal communication. More specifically, high-frequency inputs to $\mathrm{mPFC}$ during REM sleep might induce LTP in thalamocortical synapses, as shown from the effects of PILO and NIC following HFS. In agreement to that, cortical synaptic plasticity seems to occur in sleep and is thought to be a mechanism of consolidation of memories traces [37,86,87]. In contrast, low-frequency trains of MD spikes would more efficiently cause synaptic depression in the $\mathrm{mPFC}$ in a low cholinergic activity condition. Such LTD-favoring effect would be congruent with the hypothesis of sleep-dependent synaptic homeostasis, according to which slow-wave activity downscales prefrontal synapses, preparing them for ensuing wakefulness [96]. It is know that cholinergic cells of the basal forebrain and septum are also particularly active during wakefulness and are involved in the phasic and tonic cholinergic discharges during cue-detection tasks [81]. Such neuromodulation is thought to raise the sensitivity of cortical networks to afferent inputs, supporting arousal [33,4648,74-76] and enhancing the thalamocortical signal-to-noise ratio during cognitive and attention-demanding tasks [77-81]. It is possible that cognitive processes requiring $\mathrm{mPFC}$ activity, such as working memory and action planning, could undergo a statedependent bimodal cholinergic modulation [2,82-83].

In conclusion, the present study shows that the brain cholinergic activation by PILO and NIC differentially modulate LTP and LTD in the mPFC driven by the thalamus. Considering that a cholinergic unbalance in limbic circuits connected to the prefrontal cortex may contribute to major disorders, such as 
Alzheimer's disease and schizophrenia, new studies on network plasticity in freely behaving animals under low and highcholinergic tone may help to elucidate some of the prefrontal roles in such dysfunctions.

\section{Supporting Information}

Figure S1 Pairwise comparisons between drug-treated groups (aCSF, PILO and NIG) in all experimental conditions (Control, LFS and HFS). Normalized amplitude of fPSPs recorded during baseline (30 $\mathrm{min})$ and post-tetanization (240 min) are plotted in 10-min blocks. (A) aCSF; (B) PILO; (C) NIC. Significant differences were evaluated by two-way ANOVA with repeated measures, followed by Newman-Keuls post-hoc test.

\section{References}

1. Otani S (2003) Prefrontal cortex function, quasi-physiological stimuli, and synaptic plasticity. J Physiol Paris 97: 423-430.

2. Dalley JW, Cardinal RN, Robbins TW (2004) Prefrontal executive and cognitive functions in rodents: neural and neurochemical substrates. Neurosci Biobehav Rev 28: 771-784.

3. Goto Y, Yang CR, Otani S (2010) Functional and dysfunctional synaptic plasticity in prefrontal cortex: roles in psychiatric disorders. Biol Psychiatry 67: 199-207.

4. Vertes RP (2006) Interactions among the medial prefrontal cortex, hippocampus and midline thalamus in emotional and cognitive processing in the rat. Neuroscience 142: 1-20.

5. Pirot S, Jay TM, Glowinski J, Thierry AM (1994) Anatomical and electrophysiological evidence for an excitatory amino acid pathway from the thalamic mediodorsal nucleus to the prefrontal cortex in the rat. Eur J Neurosci 6: $1225-1234$

6. Kuroda M, Yokofujita J, Murakami K (1998) An ultrastructural study of the neural circuit between the prefrontal cortex and the mediodorsal nucleus of the thalamus. Prog Neurobiol 54: 417-458.

7. Uylings HB, Groenewegen HJ, Kolb B (2003) Do rats have a prefrontal cortex? Behav Brain Res 146: 3-17.

8. Negyessy L, Goldman-Rakic PS (2005) Morphometric characterization of synapses in the primate prefrontal cortex formed by afferents from the mediodorsal thalamic nucleus. Exp Brain Res 164: 148-154

9. Klein JC, Rushworth MFS, Behrens TEJ, Mackay CE, Crespigny AJ, et al. (2010) Topography of connections between human prefrontal cortex and mediodorsal thalamus studied with diffusion tractography. Neuroimage 51: 555564.

10. Eckert U, Metzger CD, Buchmann JE, Kaufmann J, Osoba A, et al. (2011) Preferential networks of the mediodorsal nucleus and centromedian-parafascicular complex of the thalamus - A DTI tractography study. Hum Brain Mapp doi: 10.1002/hbm.21389.

11. Bailey KR, Mair RG (2005) Lesions of specific and nonspecific thalamic nuclei affect prefrontal cortex-dependent aspects of spatial working memory. Behav Neurosci 119: 410-419.

12. Antoniadis EA, McDonald RJ (2006) Fornix, medial prefrontal cortex, nucleus accumbens, and mediodorsal thalamic nucleus: roles in a fear-based context discrimination task. Neurobiol Learn Mem 85: 71-85.

13. Izquierdo A, Murray EA (2010) Functional interaction of medial mediodorsal thalamic nucleus but not nucleus accumbens with amygdala and orbital prefrontal cortex is essential for adaptive response selection after reinforce devaluation. J Neurosci 30: 661-669.

14. Metzger CD, Eckert U, Steiner J, Sartorius A, Buchmann JE, et al. (2010) High field fMRI reveals thalamocortical integration of segregated cognitive and emotional processing in mediodorsal and intralaminar thalamic nuclei. Front Neuroanat 4: 138.

15. Padilla-Coreano N, Do-Monte FH, Quirk GJ (2012) A time-dependent role of midline thalamic nuclei in the retrieval of fear memory. Neuropharmacology 62 : 457-463.

16. Watanabe Y, Funahashi S (2012) Thalamic mediodorsal nucleus and working memory. Neurosci Biobehav Rev 36: 134-142.

17. Mitelman SA, Byne W, Kemether EM, Hazlett EA, Buchsbaum MS (2006) Correlations between volumes of the pulvinar, centromedian, and mediodorsal nuclei and cortical Brodmann's areas in schizophrenia. Neurosci Lett 392: 1621.

18. Kito S, Jung J, Kobayashi T, Koga Y (2009) Fiber tracking of white matter integrity connecting the mediodorsal nucleus of the thalamus and the prefrontal cortex in schizophrenia: a diffusion tensor imaging study. Eur Psychiatry 24: 269-274.

19. Pakkenberg B, Scheel-Krüger J, Kristiansen LV (2009) Schizophrenia: from structure to function with special focus on the mediodorsal thalamic prefrontal loop. Acta Psychiatr Scand 120: 345-354.
*, $\mathrm{p}<0.05$. All curves correspond to data shown in figures $4-6$. Data are shown as mean \pm SEM.

(TIF)

\section{Acknowledgments}

We would like to thank Renata Caldo Scandiuzzi and Antônio Renato Meirelles Silva for their excellent technical support, and Matheus Teixeira Rossignoli for valuable discussions.

\section{Author Contributions}

Conceived and designed the experiments: LSBJ RRP. Performed the experiments: LSBJ CLA RNR. Analyzed the data: LSBJ RRP. Contributed reagents/materials/analysis tools: JPL RRP. Wrote the paper: LSBJ RRP.

20. Volk DW, Lewis DA (2010) Prefrontal cortical circuits in schizophrenia. Curr Top Behav Neurosci 4: 485-508.

21. Floresco SB, Grace AA (2003) Gating of hippocampal-evoked activity in prefrontal cortical neurons by inputs from the mediodorsal thalamus and ventral tegmental area. J Neurosci 23: 3930-3943.

22. Herry G, Vouimba RM, Garcia R (1999) Plasticity in the mediodorsal thalamoprefrontal cortical transmission in behaving mice. J Neurophysiol 82: 28272932.

23. Herry C, Garcia R (2002) Prefrontal cortex long-term potentiation, but not longterm depression, is associated with the maintenance of extinction of learned fear in mice. J Neurosci 22: 577-583.

24. Bertram EH, Zhang D, Williamson JM (2008) Multiple roles of midline dorsal thalamic nuclei in induction and spread of limbic seizures. Epilepsia 49: 256268.

25. Sloan DM, Bertram EH (2009) Changes in midline thalamic recruiting responses in the prefrontal cortex of the rat during the development of chronic limbic seizures. Epilesia 50: 556-565.

26. Sloan DM, Zhang D, Bertram EH (2011) Excitatory amplification though divergent-convergent circuits: the role of the midline thalamus in limbic seizures. Neurobiol Dis 43: 435-445.

27. Sloan DM, Zhang D, Bertram EH (2011) Increased GABAergic inhibition in the midline thalamus affects signaling and seizure spread in the hippocampusprefrontal cortex pathway. Epilepsia 52: 523-530.

28. Buzsáki G, Gage BH (1989) The cholinergic nucleus basalis: a key structure in neocortical arousal. EXS 57: 159-171.

29. Lucas-Meunier E, Fossier P, Baux G, Amar M (2003) Cholinergic modulation of the cortical neuronal network. Pflügers Arch 446: 17-29.

30. Parent M, Descarries L (2008) Acetylcholine innervation of the adult rat thalamus: distribution and ultrastructural features in dorsolateral geniculate, parafascicular, and reticular thalamic nuclei. J Comp Neurol 511: 678-691.

31. Gu Q (2002) Neuromodulatory transmitter systems in the cortex and their role in cortical plasticity. Neuroscience 111: 815-835.

32. Giocomo LM, Hasselmo ME (2007) Neuromodulation by glutamate and acetylcholine can change circuit dynamics by regulating the relative influence of afferent input and excitatory feedback. Mol Neurobiol 36: 184-200.

33. Hasselmo ME, Giocomo LM (2006) Cholinergic modulation of cortical function. J Mol Neurosci 30: 133-135.

34. Hasselmo ME, Sarter M (2011) Modes and models of forebrain cholinergic neuromodulation of cognition. Neuropsychopharmacology Rev 36: 52-73.

35. McCormick DA (1989) Cholinergic and noradrenergic modulation of thalamocortical processing. Trends Neurosci 12: 215-221.

36. Steriade M (2004) Acetylcholine systems and rhythmic activities during the waking-sleep cycle. Prog Brain Res 145: 179-196.

37. Diekelmann S, Born J (2010) The memory function of sleep. Nat Rev Neurosci 11: $114-126$.

38. Raggenbass M, Bertrand D (2002) Nicotinic receptors in circuit excitability and epilepsy. J Neurobiol 53: 580-589.

39. Friedman A, Behrens CJ, Heinemann U (2007) Cholinergic dysfunction in temporal lobe epilepsy. Epilepsia 48 Suppl 5: 126-130.

40. Raedler TJ, Bymaster FP, Tandon R, Copolov D, Dean B (2007) Towards a muscarinic hypothesis of schizophrenia. Mol Psychiatry 12: 232-246.

41. Herholz K, Weisenbach S, Kalbe E (2008) Deficits of the cholinergic system in early AD. Neuropsychologia 46: 1642-1647.

42. Scarr E, Dean B (2009) Role of the cholinergic system in the pathology and treatment of schizophrenia. Expert Rev Neurother 9: 73-86.

43. Craig LA, Hong NS, McDonald RJ (2011) Revisiting the cholinergic hypothesis in the development of Alzheimer's disease. Neurosci Biobehav Rev 35: 13971409 .

44. Metherate R, Ashe JH (1993) Nucleus basalis stimulation facilitates thalamocortical synaptic transmission in the rat auditory cortex. Synapse 14: 132-143. 
45. Dringenberg HC, Kuo MC, Tomaszek S (2004) Stabilization of thalamo-cortical long-term potentiation by the amygdala: cholinergic and transcriptiondependent mechanisms. Eur J Neurosci 20: 557-565.

46. Dringenberg HC, Hamze B, Wilson A, Speechley W, Kuo MC (2007) Heterosynaptic facilitation of in vivo thalamocortical long-term potentiation in the adult rat visual cortex by acetylcholine. Cereb Cortex 17: 839-848.

47. Kawai H, Lazar R, Metherate R (2007) Nicotinic control of axon excitability regulates thalamocortical transmission. Nat Neurosci 10: 1168-1175.

48. Kuo MC, Rasmusson DD, Dringenberg HC (2009) Input-selective potentiation and rebalancing of primary sensory cortex afferents by endogenous acetylcholine. Neuroscience 163: 430-441.

49. Gioanni Y, Rougeot C, Clarke PB, Lepousé C, Thierry AM, et al. (1999) Nicotinic receptors in the rat prefrontal cortex: increase in glutamate release and facilitation of mediodorsal thalamo-cortical transmission. Eur J Neurosci 11: 1830 .

50. Lopes-Aguiar C, Romcy-Pereira RN, Escorsim-Szawka R, Galvis-Alonso OY, Anselmo-Franci JA, et al. (2008) Muscarinic acetylcholine neurotransmission enhances the late-phase of long-term potentiation in the hippocampal-prefrontal cortex pathway of rats in vivo: a possible involvement of monoaminergic systems. Neuroscience 153: 1309-1319.

51. Lopes-Aguiar C, Bueno-Júnior LS, Ruggiero RN, Romcy-Pereira RN, Leite JP (2012) NMDA receptor blockade impairs the muscarinic conversion of subthreshold transient depression into long-lasting LTD in the hippocampusprefrontal cortex pathway in vivo: correlation with gamma oscillations. Neuropharmacology, 10.1016/j.neuropharm.2012.09.013. In press.

52. Gigg J, Tan AM, Finch DM (1994) Glutamatergic hippocampal formation projections to prefrontal cortex in the rat are regulated by GABAergic inhibition and show convergence with glutamatergic projections from the limbic thalamus. Hippocampus 4: 189-198.

53. Groenewegen HJ, Wright CI, Uylings HB (1997) The anatomical relationships of the prefrontal cortex with limbic structures and the basal ganglia. J Psychopharmacol 11: 99-106.

54. Paxinos G, Watson C (2007) The Rat Brain in Stereotaxic Coordinates. London: Academic Press. 462 p.

55. Romcy-Pereira RN, Pavlides G (2004) Distinct modulatory effects of sleep on the maintenance of hippocampal and medial prefrontal cortex LTP. Eur J Neurosci 20: $3453-3462$.

56. Hoss W, Woodruff JM, Ellerbrock BR, Periyasamy S, Ghodsi-Hovsepian S, et al. (1990) Biochemical and behavioral responses of pilocarpine at muscarinic receptor subtypes in the CNS. Comparisons with receptor binding and lowenergy conformations. Brain Res 533: 232-238.

57. Cavalheiro EA (1995) The pilocarpine model of epilepsy. Ital J Neurol Sci 16: 33-37.

58. Dani JA, Bertrand D (2007) Nicotinic acetylcholine receptors and nicotinic cholinergic mechanisms of the central nervous system. Annu Rev Pharmacol Toxicol 47: 699-729.

59. McKay BE, Placzek AN, Dani JA (2007) Regulation of synaptic transmission and plasticity by neuronal nicotinic acetylcholine receptors. Biochem Pharmacol 74: 1120-1133.

60. Hoover WB, Vertes RP (2007). Anatomical analysis of afferent projections to the medial prefrontal cortex in the rat. Brain Struct Funct 212: 149-179.

61. Pirot S, Glowinski J, Thierry AM (1995) Excitatory responses evoked in prefrontal cortex by mediodorsal thalamic nucleus stimulation: influence of anesthesia. Eur J Pharmacol 285: 45-54

62. Ferron A, Thierry AM, Le Douarin C, GlowinskiJ (1984) Inhibitory influence of the mesocortical dopaminergic system on spontaneous activity or excitatory response induced from the thalamic mediodorsal nucleus in the rat medial prefrontal cortex. Brain Res 302: 257-265.

63. Mantz J, Godbout R, Tassin JP, Glowinski J, Thierry AM (1990) Inhibition of spontaneous and evoked unit activity in the rat medial prefrontal cortex by mesencephalic raphe nuclei. Brain Res 524: 22-30.

64. Mantz J, Milla C, Glowinski J, Thierry AM (1988) Differential effects of ascending neurons containing dopamine and noradrenaline in the control of spontaneous activity and of evoked responses in the prefrontal cortex. Neuroscience 27: 517-526.

65. Puig MV, Celada P, Díaz-Mataix L, Artigas F (2003) In vivo modulation of the activity of pyramidal neurons in the rat medial prefrontal cortex by 5 -HT2A receptors: relationship to thalamocortical afferents. Cereb Cortex 13: 870-882.

66. Hogsden JL, Dringenberg HC (2009) Decline of long-term potentiation (LTP) in the rat auditory cortex in vivo during postnatal life: involvement of NR2B subunits. Brain Res 1283: 25-33.

67. Citri A, Malenka RC (2008) Synaptic plasticity: multiple forms, functions, and mechanisms. Neuropsychopharmacology 33: 18-41.

68. Rasmusson DD (2000) The role of acetylcholine in cortical synaptic plasticity. Behav Brain Res 115: 205-218.
69. Carr DB, Surmeier DJ (2007) M1 muscarinic receptor modulation of Kir2 channels enhances temporal summation of excitatory synaptic potentials in prefrontal cortex pyramidal neurons. J Neurophysiol 97: 3432-3438.

70. Broicher T, Wettschureck N, Munsch T, Coulon P, Meuth SG, et al. (2008) Muscarinic ACh receptor-mediated control of thalamic activity via $G(q) / G(11)$ family G-proteins. Pflügers Arch 456: 1049-1060.

71. Buchanan KA, Petrovic MM, Chamberlain SEL, Marrion NV, Mellor JR (2010) Facilitation of long-term potentiation by muscarinic M1 receptors is mediated by inhibition of SK channels. Neuron 68: 948-963.

72. Lambe EK, Picciotto MR, Aghajanian GK (2003) Nicotine induces glutamate release from thalamocortical terminals in prefrontal cortex. Neuropsychopharmacology 28: 216-225.

73. Clarke PB (2004) Nicotinic modulation of thalamocortical neurotransmission. Prog Brain Res 145: 253-260.

74. Hsieh CY, Cruikshank SJ, Metherate R (2000) Differential modulation of auditory thalamocortical and intracortical synaptic transmission by cholinergic agonist. Brain Res 880: 51-64.

75. Robbins TW, Roberts AC (2007) Differential regulation of fronto-executive function by the monoamines and acetylcholine. Cereb Cortex 17 Suppl 1: i151160.

76. Metherate R (2011) Functional connectivity and cholinergic modulation in auditory cortex. Neurosci Biobehav Rev 35: 2058-2063.

77. Fanselow EE, Sameshima K, Baccala LA, Nicolelis MA (2001) Thalamic bursting in rats during different awake behavioral states. Proc Natl Acad Sci USA 98: 15330-15335.

78. Castro-Alamancos MA (2002) Role of thalamocortical sensory supression during arousal: focusing sensory inputs in neocortex. J Neurosci 22: 9651-9655.

79. Usrey WM (2002) The role of spike timing for thalamocortical processing. Curr Opin Neurobiol 12: 411-417.

80. Hirata A, Castro-Alamancos MA (2010) Neocortex network activation and deactivation states controlled by the thalamus. J Neurophysiol 103: 1147-1157.

81. Parikh V, Sarter M (2008) Cholinergic mediation of attention: contributions of phasic and tonic increases in prefrontal cholinergic activity. Ann NY Acad Sci 1129: 225-235.

82. Del Arco A, Mora F (2009) Neurotransmitters and prefrontal cortex-limbic system interactions: implications for plasticity and psychiatric disorders. J Neural Transm 116: 941-952.

83. Mansvelder HD, Mertz M, Role LW (2009) Nicotinic modulation of synaptic transmission and plasticity in cortico-limbic circuits. Semin Cell Dev Biol 20: 432-440.

84. Stenberg D (2007) Neuroanatomy and neurochemistry of sleep. Cell Mol Life Sci 64: 1187-1204

85. McCormick DA, Prince DA (1986) Mechanisms of action of acetylcholine in the guinea-pig cerebral cortex in vitro. J Physiol 375: 169-194.

86. Ribeiro S, Nicolelis MAL (2004) Reverberation, storage, and postsynaptic propagation of memories during sleep. Learn Mem 11: 686-696.

87. Romcy-Pereira RN, Erraji-Benchekroun L, Smyrniotopoulos P, Ogawa S, Mello CV, et al. (2009) Sleep-dependent gene expression in the hippocampus and prefrontal cortex following long-term potentiation. Physiol Behav 98: 44-52.

88. McCormick DA, Pape HC (1990) Properties of a hyperpolarization-activated cation current and its role in rhythmic oscillation in thalamic relay neurones. J Physiol 431:291-318.

89. Llinás RR, Steriade M (2006) Bursting of thalamic neurons and states of vigilance. J Neurophysiol 95: 3297-3308.

90. Détári L, Semba K, Rasmusson DD (1997) Responses of cortical EEG-related basal forebrain neurons to brainstem and sensory stimulation in urethaneanaesthetized rats. Eur J Neurosci 9: 1153-1161.

91. Horner RL, Kubin L (1999) Pontine carbachol elicits multiple rapid eye movement sleep-like neural events in urethane-anaesthetized rats. Neuroscience 93: 215-226.

92. Balatoni B, Détári L (2003) EEG related neuronal activity in the pedunculopontine tegmental nucleus of urethane anaesthetized rats. Brain Res 959: 304 311.

93. Dringenberg HC, Olmstead MC (2003) Integrated contributions of basal forebrain and thalamus to neocortical activation elicited by pedunculopontine tegmental stimulation in urethane-anesthetized rats. Neuroscience 119: 839 853.

94. Toth A, Hajnik T, Détári L (2012) Cholinergic modulation of slow cortical rhythm in urethane-anesthetized rats. Brain Res Bull 87: 117-129.

95. Clement EA, Richard A, Thwaites M, Ailon J, Peters S, et al. (2008) Cyclic and sleep-like spontaneous alternations of brain state under urethane anesthesia. PLoS One 3: e2004.

96. Tononi G, Cirelli C (2003) Sleep and synaptic homeostasis: a hypothesis. Brain Res Bull 62: 143-150. 